Anna-Riitta Lehtinen

Kristiina Aalto

Mitä eläminen maksaa? KOHTUULLISEN MINIMIN VIITEBUDJETTIEN PÄIVITYS VUODELLE 2018 


\section{MITÄ ELÄMINEN MAKSAA?}

\section{KOHTUULLISEN MINIMIN VIITEBUDJETTIEN \\ PÄIVITYS VUODELLE 2018}

Anna-Riitta Lehtinen

Kristiina Aalto 
Valtiotieteellisen tiedekunnan julkaisuja

- Publications of the Faculty of Social Sciences 2018:101

ISSN 2343-273X (nid)

ISSN 2343-2748 (pdf)

ISBN 978-951-51-3357-1 (nid)

ISBN 978-951-51-3358-8 (pdf)

Helsinki 2018 


\section{SISÄLLYS}

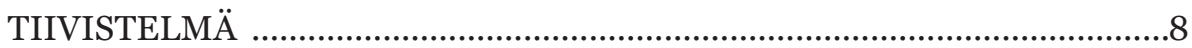

1 JOHDANTO ..................................................................................... 10

Raportin rakenne........................................................................11

2 VIITEBUDJETTIEN LÄHTÖKOHDAT JA HYÖDYNNETTÄVYYS ........ 12

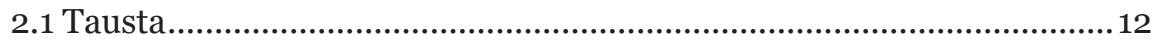

2.2 Tarpeiden määrittely ..................................................................... 13

2.3 Viitebudjettien hyödyntäminen .................................................... 15

3 VIITEBUDJETTIEN LAADINTA .................................................. 18

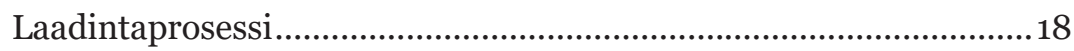

Ryhmäkeskustelut .................................................................. 19

Viitebudjettikotitaloudet .......................................................... 21

Hyödykkeiden ryhmittely ........................................................22

Periaatteet viitebudjettien laadinnassa ........................................23

Ruokabudjetin laadinta ............................................................24

Tavaroiden ja palveluiden laskentaperiaatteet ja hinnoittelu ..........25

4 VIITEBUDJETIT ESIMERKKITALOUKSILLE HYÖDYKERYHMITTÄIN .............................................................26

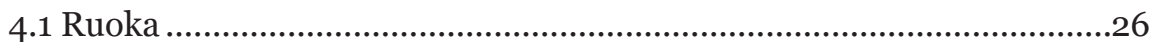

Ruokapäiväkirjat ja keskustelut ................................................... 31

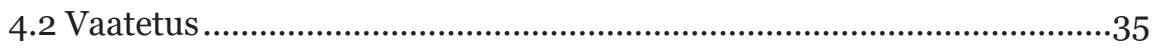

Viitebudjetin vaatteet, kengät ja asusteet ..................................... 40

4.3 Tietoliikenne ...............................................................................44

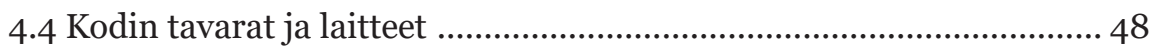

Kodinkoneet ….........................................................................49

Huonekalut ja muu kodin irtain .................................................50

Kodin tarvikkeet ...............................................................52 
4.5 Terveys, hygienia ja kauneudenhoito ……………………………….....53

4.6 Harrastukset ja vapaa-aika ...................................................................58

4.7 Asuminen............................................................................................63

Viitebudjettitalouksien asunnot ja vuokra ..........................................65

Vuokrien määrittämistä tarkennettu .................................................67

Energiakustannukset ja kotivakuutus .................................................67

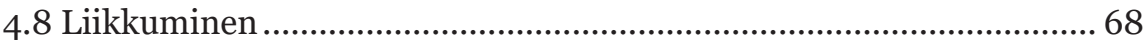

5 VIITEBUDJETTIEN YHTEENVETO JA VERTAILUJA..............................73

5.1 Viitebudjetit erilaisille kotitalouksille ........................................................73

Viitebudjettien käyttäminen ...................................................................77

5.2 Eri-ikäisten lasten kustannukset ..............................................................77

Toisen asteen opiskelijoiden oppimateriaalikustannukset ...............79

5.3 Muutokset verrattuna vuoden 2013 viitebudjettiin................................ 80

5.4 Viitebudjetit verrattuna kotitalouksien keskikulutukseen .................. 82

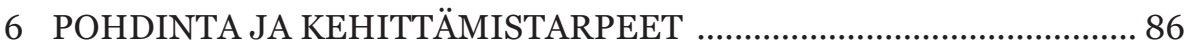

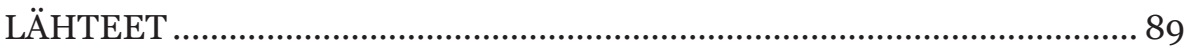

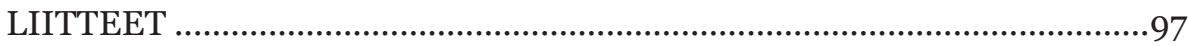




\section{Kuvaluettelo}

Kuva 1. Vertailu eräiden viitebudjettitalouksien kuluista vuosina 2015ja 2018, e/kk

Kuva 2. Viitebudjettien ja vuoden 2016 Kulutustutkimuksen kokonaismenot eri perhetyypeissä, e/kk 83

\section{Taulukkoluettelo}

Taulukko 1. Ryhmäkeskustelijoiden taustatietoja 21

Taulukko 2. Ruokakustannukset yksin asuvilla ja pareilla vuonna 2018, e/kk... 28

Taulukko 3. Ruokakustannukset lapsiperheissä vuonna 2018, e/kk. 30

Taulukko 4. Ruokakustannukset lapsiperheissä vuonna 2018, e/kk. 30

Taulukko 5. Vaatetuskustannukset viitebudjetissa eri-ikäisillä naisilla, miehillä ja lapsilla vuonna 2018, e/kk

Taulukko 6. Vaatteiden, kenkien ja asusteiden kustannukset viitebudjetissa kotitaloustyypeittäin vuonna 2018, e/kk.

Taulukko 7. Tietoliikennekustannukset viitebudjetissa kotitaloustyypeittäin vuonna 2018, e/kk

Taulukko 8. Huonekalujen, kodintekstiilien, astioiden ja ruoanvalmistusvälineiden kustannukset viitebudjetissa kotitaloustyypeittäin vuonna 2018, e/kk

Taulukko 9. Kodin tarvikkeiden kustannukset viitebudjetissa kotitaloustyypeittäin vuonna 2018, e/kk.

Taulukko 10. Terveyden, hygienian ja kauneudenhoidon kustannukset viitebudjetissa kotitaloustyypeittäin vuonna 2018, e/kk.

Taulukko 11. Vapaa-ajan ja harrastusten kustannukset kotitaloustyypeittäin vuonna 2018, e/kk 
Taulukko 12. Vuokra-asuntojen alueellinen keskikoko (m2) asuntotyypeittäin 2016

Taulukko 13. Kuukausivuokrat alueellisten vapaarahoitteisten vuokra-asuntojen keskivuokrien ja keskikokojen perusteella asuntotyypeittäin, e/kk..

Taulukko 14. Liikennekustannukset kotitaloustyypeittäin vuonna 2018, e/kk ....71

Taulukko 15. Viitebudjetit yksin asuville ja pareille vuonna 2018, $\mathrm{e} / \mathrm{kk} /$ kotitalous 75

Taulukko 16. Viitebudjetit lapsiperheille vuonna 2018, e/kk/kotitalous.............76

Taulukko 17. Eri-ikäisten lasten kustannukset, e/kk .......................................... 78

Taulukko 18. Esimerkkilukiolaisen kustannukset, e/3 vuotta 79 


\section{TIIVISTELMÄ}

Kohtuullisen minimin viitebudjettien kaikki sisällöt on päivitetty nyt ensi kertaa sitten vuoden 2010 laatimisen jälkeen. Tällä välin hintapäivityksiä on tehty vuosille 2013 ja 2015. Viitebudjettien päivityksen tavoitteena on selvittää, millainen on kohtuullisen minimin mukainen kulutustaso, jolla ihminen tulee toimeen, voi ylläpitää terveyttäänja kokeevoivansa osallistuayhteiskunnalliseen toimintaan tämän päivän Suomessa. Toisin sanoen, mitä tavaroita ja palveluja elämiseen tarvitaan, miten paljonja minkälaatuisia ne ovatja mitä nämä hyödykkeet maksavat. Tarvittavia hyödykkeitä kuvaamaan on rakennettu kohtuullisen minimin viitebudjetit. Viitebudjetti on nimensä mukaisesti viitteellinen, esimerkkilaskelma, joka osoittaa rahan tarpeen arjen sujumiselle välttämättömien tavaroiden ja palveluiden kulutukseen tietyllä aikavälillä, esimerkiksi kuukauden aikana. Budjetit on laadittu 13 esimerkkitaloudelle: nuorelleja iäkkäälle yksinasuvalle, pariskunnilleja yhden ja kahden huoltajan lapsiperheille, joissa on yhdestä kolmeen lasta. Lisäksi on laskettu eri-ikäisten lasten kustannukset sekä tehty vertailu vuoden 2016 kulutustutkimukseen.

Tavoitteena oli saada mahdollisimman monen ääni kuuluviin viitebudjettien sisällön määrittämisessä. Laatimisprosessiin osallistui 37 kuluttajaa, jotka edustivat erilaisia kotitalouksia, elämäntilanteita ja maan eri alueita. Käydyissä ryhmäkeskusteluissa haettiin kuluttajien välistä yhteisymmärrystä välttämättömäksi katsotun kulutuksen sisällöstä. Kuluttajat osallistuivat kahteen ryhmäkeskusteluun ja tekivät kotitehtäviä. Lisäksi yhdeksän neuvonta-aloja, hallintoa ja tutkimusta edustavaa asiantuntijaa arvioi luonnosvaiheessa olevien hyödykelistojen sisältöä. Hyödykelistojen valmistumisen jälkeen hyödykkeet hinnoiteltiin. Hinnat kerättiin alkuvuodesta 2018.

Budjetit sisältävät seuraavat kulutusmenoryhmät: ruoka, vaatetus, kodin tavarat ja laitteet, tietoliikenne, vapaa-aika, terveys ja hygienia sekä asuminen ja liikkuminen. Liikkuminen ja asuminen ovat viitebudjetissa erillisenä menoryhmänä, joten menot voidaan laskea asuinpaikan ja tarjolla olevien liikennevaihtoehtojen mukaan. Yli vuoden kestäville tavaroille on laskettu kestoiän mukaan vuotuisen kulumisen arvo, ja vain tämä erä otettiin mukaan viitebudjetteihin. Ruokamenot perustuvat ryhmäkeskustelujen lisäksi tutkimukseen osallistuneiden kuluttajien pitämiin ruokapäiväkirjoihin, ja voimassa oleviin ravitsemussuosituksiin. Viitebudjettiin sisältyvät hyödykkeet ja budjettien pohjana olevat ruokalistat on yksilöity raportin liitteissä. 
Ryhmäkeskustelujen ja asiantuntijakommenttien perusteella hyödykeryhmien sisältöön on tehty joitakin muutoksia. Keskustelijat ehdottivat hyödykelistalle lisää kotitaloustarvikkeita ja vaatteita, joten niitä täydennettiin. Useimmissa tuoteryhmissä kustannukset ovat hieman nousseet vuosien 2015 ja 2018 välillä. Suurimmat kustannusten muutokset ovat ruoassa, autoilussa, asumisessa ja terveysmenoissa. Ruoan hinnan laskun sekä useampien kotona valmistettavien aterioiden vuoksi kotitalouskohtaiset ruokamenot ovat laskeneet yksin asuvien talouksissa noin 15 euroa ja lapsiperheissä 70-96 euroa kuukaudessa. Autoilun kustannukset ovat laskeneet puolestaan verotusmuutosten vaikutuksesta verrattuna aiempaan viitebudjettiin. Asumisen kustannukset viitebudjetissa ovat laskeneet, koska vuokrien laskentaa on tarkennettu. Vuokrat perustuvat nyt alueellisiin asuntotyyppien keskikokoihin ja alueellisiin asuntotyyppien keskineliövuokriin. Lääkekustannukset ovat kasvaneet, koska ehkäisypillereiden ja reseptilääkkeiden kustannukset otettiin mukaan. Reseptilääkekulut hinnoiteltiin Kelan tilaston mukaisina omavastuun mediaanikuluina iän ja sukupuolen perusteella. Tämä korotti erityisesti yli 65-vuotiaiden lääkekuluja. Aiemman viitebudjetin harrastuksiin ja vapaa-aikaan varattua rahamäärää keskustelijat pitivät liian pienenä. Nyt lasten harrastuksiin varattu rahamäärä kaksinkertaistettiin, jotta yhteen harrastukseen on mahdollisuus.

Viitebudjettien kokonaiskulutus on hyvin maltillista verrattuna vuoden 2016 kulutustutkimukseen eli vastaavien kotitalouksien keskimääräiseen kulutukseen. Viitebudjettitalouksien välttämättömien kulujen yhteissumma kuukaudessa vaihtelee pääkaupunkiseudulla yksin asuvien alle 45-vuotiaiden noin 1380 eurosta kahden vanhemman ja kolmen teinin perheen noin 4250 euroon (Helsingissä noin $1380-4310$ e/kk ja muualla Suomessa noin 1 130-3 770 e/kk). Asuminen ja ruoka ovat selvästi suurimmat menoerät viitebudjetissa. 


\section{JOHDANTO}

Kohtuullisen minimin viitebudjettien sisältö päivitetään nyt ensimmäistä kertaa. Suomen ensimmäiset viitebudjetit valmistuivat kahdeksan vuotta sitten vuonna 2010 (Lehtinen ym. 2010). Vuoden 2010 jälkeen on tapahtunut muutoksia kuluttajien toimintatavoissa ja yhteiskunnassa, joten viitebudjetit on syytä päivittää, jotta ne vastaavat ajankohtaisiin tarpeisiin. Laatimisen jälkeen tuotteiden hintoja on päivitetty kaksi kertaa (vuosille 2013, 2015) ja hyödykelistoihin tehty pieniä tarkennuksia vuonna 2013 (Lehtinen \& Aalto 2014).

Hankkeessamme kuluttajien välttämättömiksi arvioimat kulutustarpeet kootaan hyödykelistoiksi, jotka hinnoitellaan määätyn hintatason mukaan. Suomessa viitebudjetit on laadittu kohtuullisen minimin tasolle. Viitebudjetit ovat lista tavaroita ja palveluja, joita määrätyn iän ja rakenteen omaava perhe tarvitsee elääkseen määrätyn elintason mukaista elämää tietyssä ajassa ja paikassa. Kohtuullinen minimi tarkoittaa ihmisarvoisen (säällisen) elämän mahdollistavaa kulutusta eli ihminen tulee toimeen ja voi ylläpitää terveyttä sekä kokee voivansa osallistua sosiaaliseen ja yhteiskunnalliseen toimintaan tämän päivän suomalaisessa yhteiskunnassa (ks. Borgeraas 1987).

Nimensä mukaisesti viitebudjetit ovat viitteellisiä, esimerkkilaskelmia määrätyille kotitaloustyypeille. Ne ovat myös läpinäkyviä, jolloin tuotteita voidaan vaihtaa budjetin sisällä paremmin omia tarpeita vastaavaksi. Kohtuulisen minimin viitebudjettien avulla voidaan laskea, mitä kulutus maksaa niukalla kulutustasolla. Ilman tarpeellisten hyödykkeiden konkretisointia, niiden hinnoittelu ei ole mahdollista. Australialaiset Peter Saunders ja Megan Bedford (2017) muistuttavat, etteivät budjetit vastaa täydellisesti todellisuutta vaan heijastelevat sitä, eivätkä ne korvaa päätöksentekoa, vaan auttavat siinä. Viitebudjetteja voidaan hyödyntää ja on hyödynnetty monissa yhteyksissä, kun pohditaan kulutuksen tasoa tai arvioidaan rahojen riittävyyttä kohtuulliseksi katsottuun elämään.

Päärahoitus nyt tehtyyn päivitykseen on saatu Suomen Akatemian strategisen tutkimuksen neuvoston rahoittamasta TITA-konsortiohankkesta, Eriarvoisuuden torjuminen niukkuuden aikana (Tackling Inequalities in a Time of Austerity, päätös nro 293103) ${ }^{1}$.

1 http://blogit.utu.fi/tita/ 


\section{Raportin rakenne}

Luvussa 2 esitetään lyhyesti viitebudjettien laadinnan lähtökohtia ja viitebudjettien käyttöä muutamissa maissa. Luvussa 3 on kuvattu kohtuullisen kulutuksen määrittelyssä käytetty laadintaprosessi sekä hyödykkeiden hinnoittelun periaatteet ja viitebudjettitaloudet eli esimerkki taloudet, joille viitebudjetit on laadittu. Luvussa 4 puolestaan esitellään viitebudjettien sisällöt hyödykeryhmittäin ja hyödykkeiden kustannuksia viitebudjettitalouksissa. Yksityiskohtainen luettelo viitebudjetteihin sisältyvistä hyödykkeistä esitetään liitteissä 1 ja 2 sekä esimerkkiruokalistat liitteessä 3. Esimerkkikotitalouksien viitebudjettikokonaisuudet esitellään yhteenvedonomaisesti luvussa 5. Luvussa tarkastellaan lisäksi eri- ikäisten lasten esimerkkikustannuksia sekä verrataan vuoden 2018 budjetteja aiempiin kohtuullisen minimin viitebudjetteihin sekä vuoden 2016 kulutustutkimukseen. Luvussa 6 arvioidaan tutkimusta sekä esitetään kehittämistarpeita. 


\section{VIITEBUDJETTIEN LÄHTÖKOHDAT JA HYÖDYNNETTÄVYYS}

\subsection{TAUSTA}

Tämä viitebudjettien päivitys noudattaa samoja periaatteita kuin vuonna 2010 laatimamme ensimmäiset viitebudjetit (Lehtinen ym. 2010). Kuten tuolloin, myös nyt on tavoitteena tuottaa luettelo hyödykkeistä, joita elämiseen välttämättä tarvitaan tämän päivän yhteiskunnassa ja laskea mitä se kaikki maksaa. Lähtökohtana ovat ihmisten perustarpeet yhdistettynä heidän tavanomaiseen toimintaansa ja lopputuloksena on tuottaa laskennallinen vertailutaso, läpinäkyvä malli, johon voidaan peilata yksilöiden ja kotitalouksien todellista tilannetta ja yksilöllisiä tarpeita (ks. Aatola \& Viinisalo 1998). Määritämme viitebudjetit kohtuullisen minimin tasolle. Kohtuullisella minimillä tarkoitamme kulutustasoa, joka sisältää jokapäiväisessä elämässä tarvittavia tavaroita ja palveluja, joita ilman arki ei suju. Emme määritä köyhyysrajaa, myöskään kuluttajia ei ole pyydetty ryhmäkeskusteluissa sitä määrittämään, mutta jos kulutus on kohtuullisen minimin alapuolella, niin kotitalouden resurssit toimia ja osallistua ovat puutteelliset. Kohtuullisen minimin mukainen viitebudjetti sisältää nykyisin välttämättöminä tai useimpien mielestä lähes välttämättöminä pidetyt tuotteet ja palvelut arjen sujumiseksi.

Viitebudjettien laadinnassa on olennaista se, kuka tai ketkä määrittelevät ne hyödykkeet, jotka hyödykekoriin valitaan ja miten ne hinnoitellaan (Aatola ja Viinisalo 1998; Hirsch 2010; Deeming 2010). Päivittämiemme budjettien laadinnassa keskeisintä ovat olleet kuluttajien kanssa käydyt ryhmäkeskustelut, joissa kuluttajat pohtivat välttämättömiä hyödykkeitä arkielämänsä kannalta eli ihminen tulee toimeen, voi ylläpitää terveyttään ja ottaa osaa yhteiskunnalliseen toimintaan. Kuluttajien osallistuminen on tärkeää ja heidän aktiivinen paneutumisensa pohdintaan laajentaa ja konkretisoi erilaisista vaihtoehdoista johtuvia kustannuksia. On tärkeää saada mukaan erilaisia kuluttajia, eri-ikäisiä, erilaisissa perhemuodoissa eläviä, sekä ammatiltaan ja koulutukseltaan erilaisia miehiä ja naisia (Bradshaw 2008; Deeming 2010; Lehtinen ym 2013). Asiantuntijat ovat olleet myös nyt arvioimassa kuluttajakeskustelujen pohjalta laadittuja hyödykekoriluonnoksia. 
Kohtuullisen minimin mukaisen hyödykekorin sisällön määrittäminen ja hinnoittelu ovat edelleen haastavia tehtäviä tämän päivän yhteiskunnassa (Lehtinen ym. $2010 \mathrm{~s}$ 14). Kulutusyhteiskunnassa on runsaasti toiminta- ja valintamahdollisuuksia ja niiden runsaus saattaa hämärtää käsitystä siitä, mikä on todella välttämätöntä ja tarpeellista, toisin sanoen, puhutaanko tarpeista vai haluista. Välttämättömyys on suhteellista ja rajanveto välttämättömien ja ei-välttämättömien hyödykkeiden välille on hankalaa, mihin vaikuttavat kulttuuri, maantieteellinen sijainti, yhteiskunnan tarjoamat palvelut ja aika. Välttämättömät hyödykkeet vaihtelevat yksilöittäin, sillä niiden määräytymiseen vaikuttavat yksilön demografiset ja henkilökohtaiset ominaisuudet sekä elinvaihe. On vaikeaa määrittää oikeaa ja hyväksyttävää kulutusta, joka sekin vaihtelee aikakausittain. Siihen vaikuttavat taustalla poliittinen järjestelmä, valtiovalta, opetus, järjestöt, markkinat, media ja tiede. (ks. Lehtinen ym. 2010.) Edelleen, kullakin kotitaloudella on omat toimintatapansa ja resurssinsa toiminnan ylläpitämiseen.

Viitebudjetit ovat esimerkkejä siitä, mitä määrätyllä rahamäärällä voi hankkia, eikä mitä kunkin pitäisi hankkia tai mitä sosiaalisen suotavuuden mukaan tulisi kullakin olla (mm. Hircsh 2010; Saunders \& Bedford 2017). Rahamäärän pohjaksi tarvitaan käsitys siitä, mitä määrätylle kulutustasolle tarvitaan, jotta se voidaan hinnoitella. Viitebudjeteilla on oltava yhteys todelliseen maailmaan, sen olosuhteisiin ja kuluttajien kohtaamiin taloudellisiin tilanteisiin (Saunders \& Bedford 2017). Suomessa kuluttajien kanssa ei ole keskusteltu yksittäisten tuotteiden hinnoista, vaan yksinomaan tutkijat ovat hinnoitelleet tuotteet. Syynä tähän on ensinnäkin se, että hintakeskusteluun tarvitaan useampi keskustelukerta kuin kaksi. Toiseksi, hinnoista ja rahasta puhuminen siirtää huomion muualle kuin viitebudjetin sisältöön ja tavoitteeseen. Ryhmissä on keskusteltu yleisellä tasolla, mikä on kallista tai edullista, mitkä ovat hyviä ostopaikkoja joillekin tuotteille, mutta niissä ei keskusteltu yksittäisten tuotteiden hinnoista budjeteissa. Olemme kertoneet keskusteluissa hintatason, jonka mukaan tuotteet on aiemmin hinnoiteltu, ja keskustelijat ovat sen hyväksyneet käytettäväksi myös tässä päivityksessä.

\subsection{TARPEIDEN MÄÄRITTELY}

Amartya Senin ja Martha Nussbaumin näkemykset ihmisten toimintamahdollisuuksista ja Ken Doyalin ja Ian Goughin laatimat universaalit inhimilliset tarpeet ovat luoneet pohjan 2000-luvulla laadittuihin viitebudjetteihin. Nïn on myös käsillä olevassa päivityksessäja ensimmäisissä viitebudjeteissa vuodelta 2010 (ks. Lehtinen ym. 2010). Sen (1995) näkee köyhyyden tulojen ja taloudellisten resurssien puuteeksi, mikä erityisesti rajoittaa köyhän valinnanvapautta elämässä ja mahdollisuutta toteuttaa omaa elämäänsä haluamallaan tavalla. Taloudellisten resurssien 
vähäisyys ilmenee ennen kaikkea mahdollisuuksien ja vaihtoehtojen puutteena sekä laajemminkin toimintarajoituksina (Sen 1995). Miten hyvin ihminen pystyy resurssejaan hyödyntämään, riippuu niistä ympäristöistä ja olosuhteista, joissa ihminen toimii. Resurssien käyttöä voi ajatella ohjaavan Senin (1995) esittämät toimintamahdollisuudet (capabilities). Hyödykkeet ovat arvokkaita, koska niillä on erilaisia toimintoja (functionings) mahdollistavia ominaisuuksia. Sen ei ole listannut välttämättömiä toimintamahdollisuuksia, mutta Nussbaum (2011) sekä Doyal ja Gough (1991) ovat täydentäneet niitä tavoitteena sellaisten tarpeiden tyydytys, jotta voi osallistua yhteiskunnalliseen elämään ja kunkin toimintamahdollisuudet toteutuvat. Edelliset ovat edellytys elinvoimaiselle elämälle.

Doyal ja Gough (1991) ovat tarveteoriassaan nimenneet autonomian ja terveyden universaaleiksi perustarpeiksi, joiden toteutuessa osallistuminen mihin tahansa sosiaaliseen elämään on mahdollista. Perustarpeita tyydyttää joukko universaaleja välittäjätarpeita: ravitseva ruoka ja vesi, riittävän suojan mahdollistava asunto, turvallinen työympäristö ja fyysinen ympäristö, terveydenhuolto, turvallinen lapsuus, merkitykselliset ihmissuhteet, fyysinen ja taloudellinen turvallisuus sekä peruskoulutus. (Doyal \& Gough 1991; Gough 2017). Edellä lueteltuja välittäjätarpeita on käytetty hyväksi viitebudjettien laadintaprosesseissa, sillä ne ovat konkreettisia ja toimivat hyvin viitekehyksenä (Storms \& Van Den Bosch 2009).

Ranskalaiset viitebudjettien laatijat (CREDOC 2014) kuitenkin epäilevät, ettei kaikkia Doyalin ja Goughin (1991) luettelemia tarpeita voidaan tyydyttää. Esimerkiksi he nostavat terveellisen ympäristön ja fyysisen turvallisuuden. Ilman ja veden saastumisen ja turvallisen elinympäristön saavuttaminen ovat asioita, joihin ei voi itse aina vaikuttaa (Gough 2017). Ranskalaiset pohtivat myös, miten julkiset palvelut huomioidaan budjeteissa (terveydenhuolto, koulutus, liikenne) kuluttajalähtöisessä tarkastelussa (CREDOC 2014). Stormsin ja Van den Boschin (2009) mukaan viitebudjetit voivat olla tasoltaan alhaisempia, kun huomioidaan yhteiskunnan muut rakenteet, jotka lisäävät myös toimintamahdollisuuksia. Suomessa Tilastokeskus (2018c) on laskenut hyvinvointipalvelujen arvon olleen 7100 euroa kotitaloudelle vuonna $2016 \mathrm{ja}$ eniten vastinetta maksetuille veroille on saatu koulutuksesta ja terveydenhoidosta.

Ilmastonmuutoksen ja kestävän kehityksen huomioiminen ovat asioita, jotka vaikuttavat kulutukseen ja siten myös viitebudjetteihin ja tulevaisuuden hyvinvointiin. Kestävän kehityksen tavoitteet ja elämän riittävät taloudelliset edellytykset eivät voi olla ristiriidassa (Aatola ja Viinisalo 1995). Gough (2017) viittaa Britanniassa tehtyyn vuoden 2014 viitebudjettiin (Minimum Income Standard). Jos Ison-Britannian väestö eläisi kyseisen viitebudjetin mukaisesti, kulutuksesta aiheutuvat kasvihuonekaasujen päästöt olisivat reilun kolmanneksen alhaisemmat (Druckman \& Jackson 2010). Samansuuntaisia tuloksia on saatu Suomen kensimmäisten viitebudjettien pohjalta tehdyistä hiilijalanjälkilaskelmista (ks. 
Lettenmeier ym. 2012). Kysyttäessä kuluttajien yhteistä näkemystä ympäristömyötäisestä vähäpäästöisestä kulutuksesta Britanniassa, kuluttajat ovat periaatteessa suopeita vähäpäästöiselle kulutukselle, vaikka se ei aina käytännössä onnistu. Yksittäisen kuluttajan saattaa olla vaikea nähdä niitä keinoja, joilla kulutus on luontoa säästävää (Druckman ym. 2011).

\subsection{VIITEBUDJETTIEN HYÖDYNTÄMINEN}

Viitebudjettien laatiminen on yleistynyt merkittävästi 2000-luvulla. Erityisesti Euroopassa on laadittu budjetteja, sillä Euroopan Unioni on ollut rahoittamassa useita viitebudjettihankkeita. Komission kiinnostuksen taustalla budjetteja kohtaan on ollut hyödyntää niitä syrjäytymisen ehkäisyyn ja työvälineeksi, kun kehitetään keinoja kansalaisten riittävän toimeentulon takaamiseksijäsenvaltioissa sekä kehittää yhteistä laadintamenetelmää (Warnaar \& Luten 2009; Goedemé ym. 2015). Aiemmin budjetteja laadittiin ainoastaan asiantuntijoiden ja tutkijoiden toimesta, jolloin niitä kutsuttiin standardibudjeteiksi. Suomessa Aatolan ja Viinisalon laatima standardibudjetti julkaistiin vuonna 1998. Tutkijoiden ohella asiantuntijaryhmä oli aktiivisesti mukana hyödykekorien laadinnassa. Aatola ja Viinisalo (1998) kutsuivat sitä suppeaksi konsensukseksi. Pohjoismaissa Norjassa, Ruotsissa ja Tanskassa asiantuntijat ovat laatineet budjetteja hyvin pitkään. Budjetteja on laadittu Norjassa ja Ruotsissa liki 40 vuotta. Norjassa on viime vuosina kehitetty kuluttajakeskusteluja asiantuntijoiden työn tueksi. Hollannissa asiantuntijat ovat laatineet viitebudjetteja yli 30 vuotta sekä kuluttajien avustuksella on tehty minimibudjetti. Australiassa on laadittu budjetteja pitkään, aiemmin asiantuntijoiden toimesta, nyt asiantuntijoiden ja kuluttajien yhteistyönä.

Isossa-Britanniassa on laadittu budjetteja pisimpään Euroopassa, ensimmäisen standardibudjetin laati Seabohm Rowntree vuonna 1901. Britanniassa asiantuntijat laativat ensin standardibudjetteja, mutta sittemmin kuluttajien osallistuminen on noussut tärkeimmäksi osaksi laadintaprosessia, kuten on myös Irlannissa. Ison-Britannian viitebudjettia kutsutaan Minimum Income Standardiksi (MIS) (Bradshaw ym. 2008; Davis ym. 2015). Sen tavoitteena on määrittää erityyppisille kotitalouksille sosiaalisesti hyväksyttävä elintaso kuluttajien saavuttaman yhteisymmärryksen pohjalta. Laadintaan osallistuu lisäksi ravitsemuksen ja energia-alan asiantuntijoita. Britanniassa on laadittu myös minimitulot ja terveellinen elämä-budjetti (Minimum Income for Healthy Living). Kyseinen budjetti on tehty 18-30 vuotiaille miehille ja iäkkäille kulutustutkimuksen (Family Expenditure Surveyn) pohjalta ja hinnoiteltu minimihinnoin (Morris \& Deeming 2004; Morris ym. 2007). Kuluttajien osallistuminen viitebudjettien laadintaan on lisännyt niiden suosiota. Ison-Britannian ja Irlannin kokemukset sekä Ison-Britannian 
konsultaatiot muissa maissa ovat edistäneet suosion kasvua. Tuorein kuluttajakeskusteluin laadittu viitebudjetti valmistui Ranskaan vuonna 2014. Myös Japanissa, Itävallassa ja Portugalissa on hyödynnetty Ison-Britannian kuluttajien konsensukseen pyrkivää menetelmää.

Euroopan unioni rahoitti vuonna 2013-2015 hanketta, jossa pyrkimyksenä oli yhtenäinen metodologia ja viitekehys viitebudjettien rakentamiseen, luoda verkosto asiantuntijoiden kesken ja laatia ruokabudjetti 26 jäsenmaahan. Ruokabudjetin lisäksi kahdeksaan jäsenmaahan laadittiin asumisen ja henkilökohtaisen hygienian viitebudjetit (Goedemé ym. 2015). Laadintamenetelmät ovat poikenneet toisistaan eri maissa, jolloin maiden välisiä vertailuja on ollut hankala tehdä. Yhteinen viitekehys ja toimiva verkosto asiantuntijoiden kesken vähentänee tulevaisuudessa kyseistä ongelmaa.

Useimmat laaditut viitebudjetit ovat ns. minimibudjetteja tai kohtuullisen kulutuksen viitebudjetteja. Minimitasoisessa budjetissa kulutustaso on hyvin matala, kohtuullisessa aavistuksen korkeampi kuin minimibudjetissa eli vain välttämättömäksi katsottujen hyödykkeiden lisäksi joitain tarpeellisiksi katsottuja hyödykkeitä, sellaisia, jotka ovat yleisiä kussakin yhteiskunnassa ja kulttuurissa. Vaikka nimi on muuttunut ja laadinta erilaista eripuolilla maailmaa, tavoite on sama kuin Rowntreellä yli sata vuotta sitten.

Suomessa viitebudjetit ovat olleet mukana perusturvan riittävyyden arvioinnissa, jossa tarkastellaan yksittäisten etuuksien ja perustoimeentuloon vaikuttavien tekijöiden kokonaisuutta sekä etuuksia saavien kotitalouksien toimeentuloa. (ks. THL 2011; 2015). Tarkastelu tehdään vaalikausittain neljän vuoden välein. Viitebudjetteja on käytetty materiaalina myös erilaisissa tutkimuksissa, selvityksissä sekä opetuksessa. Niin ikään yksittäiset kuluttajat ovat olleet kiinnostuneita niistä. Viitebudjetteja on mahdollisuus hyödyntää talous- ja velkaneuvonnan sekä kuluttajaneuvonnan oheismateriaalina, kuten Ruotsissa on tehty. Siellä viitebudjettien pohjalta tehdään vuosittain opas, joka tarjoaa mahdollisuuden oman budjetin tekoon ja viitetietoina ovat kuluttajaviraston, Konsumentverketin, tekemät budjettilaskelmat (Konsumentverket 2018). Ruotsissa budjetit ovat pohjana toimeentulotuelle (riksnorm). Norjassa budjetteja käytetään neuvonnassa, sen lisäksi oman talouden budjettiseurantaan on mahdollisuus käyttää laskuria (SIFO 2018). Isossa-Britanniassa kaikkein tärkeintä on ollut budjettien käyttö, mittapuuna tai kriteerinä (benchmark), minimipalkkoihin, eri väestöryhmien toimeentuloon, asumisen ja sosiaaliturvan muutoksiin. Myös heillä on käytössä laskuri, josta näkee, mihin kullakin kotitaloustyypillä pitäisi olla varaa Isossa-Britanniassa ${ }^{2}$.

2 Do you earn enough for a decent standard of living? https://www.minimumincome.org.uk/ 
Hollannissa Nibud ${ }^{3}$ käyttää tekemiään laskelmia neuvontamateriaalissa, joka sisältää laskureita, mallipohjia ja eri ikäryhmille kohdennettua tietoa omasta taloudesta.

Viitebudjetit ovat saaneet arvostelua siitä, että laskelmat on tehty suppean kuluttajajoukon näkemyksistä, ja on jouduttu tekemään erilaisia olettamuksia ja kompromisseja laadintaprosessin aikana. Monien maiden budjeteissa on olettamus, että viitetalouden jäsenet ovat terveitä, ja sen mukaisesti lääkemenot ovat alhaiset. Viitebudjettien yksi lähtökohta on ylläpitää terveyttä, ei niinkään määrättyjen sairauksien hoito. Iäkkäillä kuluttajilla on usein sairauksia, joiden hoitaminen on kallista. On hankala ottaa kantaa, millaisten sairauksien hoitoon varataan rahaa budjetteihin tai miten hyödynnetään Suomessa käytössä olevaa henkilökohtaista lääkekustannusten omavastuuta. Toistaiseksi ei ole viitebudjettia, jossa olisi arvioitu laitoksissa asuvien kulutusta tai millainen budjetti laaditaan ihmisille, joilla on erityistarpeita. Asumisen kustannukset ovat toinen ryhmä, jossa tehdään olettamus vuokra-asumisesta. Pienituloisista suurin osa asuu vuokralla, vaikka enemmistö suomalaisista asuu omistusasunnoissa (Kauppinen ym. 2015). Asumisen kustannuksia arvioitaessa pitäisi huomioida eri alueiden vuokrataso, asuntolainan kohtuulliset lainanhoitokulut tai mikä on sopivan kokoinen asunto kullekin taloudelle. Suomen lisäksi monessa maassa asumisen kustannukset vaihtelevat maan eri alueiden välillä.

Viitebudjettien pohjalta on virinnyt kansainvälistä keskustelua, voisiko viitebudjetteja hyödyntää köyhyyden mittaamisessa (Penne ym. 2016). Yleisesti käytetty köyhyysmittari on 60 prosenttia ekvivalentista mediaanitulosta eli tuloköyhyysriskimittari (at risk of poverty indicator). Se on saanut osakseen arvostelua, koska siitä puuttuu kytkentä kotitalouden tulojen ja tarpeentyydytyksen väliltä (ks. Mäkinen 2017). Mittari ei kuvaa todellisia tilanteita, eikä keitä köyhät ovat. Viitebudjettiin perustuva köyhyysmittari olisi tuloköyhyysmittaria kattavampi, koska se ottaa huomioon asumisen ja aineettomat resurssit. Viitebudjettien käyttöön liittyy kuitenkin ongelmia: olettamukset esimerkkiperheiden koostumuksesta, niiden jäsenten terveydestä ja kuka määrittää viitebudjettien sisällön. (Mäkinen 2017.) Terveyden ja hyvinvoinnin laitos (THL) arvioi minimibudjettiköyhyyttä, jossa pohjana ovat viitebudjetit, perusturvan varassa elävien käytettävissä olevat tulot sekä keskipalkat. Minimibudjettiköyhyys tavoittaa Terveyden ja hyvinvoinninlaitoksen laskelmien mukaan syvempää köyhyyttä kuin tuloköyhyysmittarilla mitattu (Moisio ym. 2016).

3 Nibud (Nationaal Instituut voor Budgetvoorliching, Institute for Family Finance Information) 


\section{VIITEBUDJETTIEN LAADINTA}

Suomen ensimmäiset viitebudjetit laadittiin vuonna 2010 konsensusmenetelmällä, jolloin niitä oli laatimassa ja periaatteista sopimassa kuluttajien, asiantuntijoiden ja viiden tutkijan ryhmä (Lehtinen, Varjonen, Raijas, Aalto \& Pakoma 2010). Tuolloin kuluttajien näkemyksiä oli tuomassa esiin 53 kuluttajaa, joista lähes kaikki olivat mukana kaikilla kolmella keskustelukierroksella. Kuluttajat tekivät lisäksi kotitehtäviä: arvioivat, mitkä hyödykkeet ovat välttämättömiä tai tarpeellisia sekä pitivät viikon ajan ruokapäiväkirjaa. Keskusteluryhmistä viisi kokoontui Helsingissä, yksi Oulussa ja yksi Joensuussa. Ensimmäisen laadintaprosessin aikana viitebudjetit laadittiin kuudelle viitebudjettitaloudelle: neljä erilaista yksin asuvien taloutta (alle 45-v ja yli 65-v miehet ja naiset), keski-ikäinen pari ja lapsiperhe (vanhemmat sekä 4- ja 10-v lapset). Menetelmä on kuvattu yksityiskohtaisesti raportissa (Lehtinen ym. 2010).

Vuonna 2013 viitebudjetteja päivitettiin ja lisättiin kolme viitebudjettitaloutta: kaksilapsinen yhden huoltajan perhe ja kahden huoltajan lapsiperheet, joissa on teini-ikäisiä lapsia, toisessa kaksi ja toisessa kolme (ks. Lehtinen \& Aalto 2014). Päivityksen yhteydessä viitebudjetin lapsiperheen hyödykekorin sisältöä tarkistettiin uusien ryhmäkeskustelujen ja kotitehtävien avulla. Keskustelukierroksia käytiin tuolloin vain yksi ja niihin osallistui 18 kuluttajaa. Kaksi ryhmää kokoontui Helsingissä ja yksi Tampereella. Myöhemmin ainoastaan hinnat päivitettiin raportin yhteenvetotaulukkoon vuoden 2015 tasolle (Lehtinen \& Aalto 2014, päivitys 11.4.2016, s. 28). Päivitys tehtiin Tilastokeskuksen kuluttajahintojen tuoteryhmittäisten indeksien avulla.

\section{Laadintaprosessi}

Käsillä olevien viitebudjettien laatimisessa noudatettiin samaa menetelmää kuin ensimmäisellä kerralla (Lehtinen ym. 2010) ja sitä täydentävällä kierroksella 2013 (Lehtinen \& Aalto 2014). Tässä päivityksessä saatoimme hyödyntää aiempia viitebudjettien hyödykelistoja uusien laadinnan pohjana ja keskustelukierroksia oli kaksi. Osallistujille lähetettiin valmiit hyödykeluettelot, joita heidän oli mahdollista kommentoida. Kolmatta keskustelukertaa ei järjestetty, sillä sen anti oli vähäisin budjetin sisältöihin vuonna 2010 (Lehtinen ym. 2010). Vuonna 2010 aloitimme ns. puhtaalta pöydältä, mutta nyt tilanne on ollut toinen, sillä osa keskustelijoista tunnisti ja tiesi viitebudjetit, minkä vuoksi tiivistimme prosessia. Keskustelujen rungot ovat olleet samat kuin vuonna 2010 ja 2013. 
Viitebudjettien laatiminen koostuu seuraavista vaiheista:

1. Ryhmäkeskustelut kuluttajien kanssa

2. Yksilötehtävä (kotitehtävät)

3. Paritehtävä ja ryhmäkeskustelu

4. Tutkijat analysoivat aineiston ja kokoavat listan välttämättömistä tuotteista ja palveluista

5. Tutkijat kokoavat tavara- ja palvelukoriluonnokset erilaisille kotitalouksille

6. Asiantuntijaryhmä arvioi tavara- ja palvelukoriluonnoksia (yhdessä)

7. Luettelot lähetetään keskusteluihin osallistuneille kuluttajille kommentoitaviksi

8. Tavaroille ja palveluille kootaan hinnat

9. Tutkijat viimeistelevät laskelmat viitebudjeteiksi

Yhteisymmärryksen saavuttamisen kannalta on tärkeää, että keskustelijat kokoontuvat vähintään kaksi kertaa. Ensimmäisessä kokoontumisessa keskustellaan yleisellä tasolla siitä, mitä toimintoja kuuluu arkeen ja osallistumiseen tämän päivän yhteiskunnassa, jotta talous on toimintakykyinen. Samalla keskustelijat alkavat pohtia, mitkä hyödykkeet ovat tarpeellisia tai välttämättömiä toimivassa arjessa. Tuotteita ja palveluita pohditaan nimenomaan tarpeiden kautta. Viitebudjetti ei kuvaa keskiarvokulutusta tai mitä haluaisi omistaa, vaan se kuvaa välttämätöntä kulutusta, jossa kullakin hyödykkeellä on merkitystä arjen sujuvuuden, terveyden ylläpitämisen ja osallistumisen kannalta. Esimerkiksi kulutustutkimus tuottaa arvokasta tietoa kotitalouksien toteutuneen keskiarvokulutuksen kuvaajana, mutta luvut eivät kerro, onko hyödykkeitä hankittu enemmän vai vähemmän kuin olisi tarvittu.

Kuluttajien painotuksia noudattavat hyödykelistat lähetettiin asiantuntijaryhmälle, joka kokoontui keskustelemaan ja kommentoimaan listoja. Asiantuntijaryhmä koostui yhdeksästä eri alojen asiantuntijasta (tutkimus, viranomainen/ministeriön, talous- ja velkaneuvonta, kolmas sektori). Asiantuntijoiden kommenttien jälkeen korjatut listat lähetettiin ryhmäkeskusteluihin osallistuneille kuluttajille, jotta heillä oli mahdollisuus vielä ottaa kantaa niiden sisältöön ja lukumääriin. Viimeisenä vaiheena tutkijat kokosivat tuotteiden hinnat ja laskivat viitebudjetit erilaisille esimerkkitalouksille.

\section{Ryhmäkeskustelut}

Ryhmäkeskustelijoiden rooli on keskeisin määritettäessä viitebudjettiin mukaan otettavia tuotteita ja palveluja. Keskustelujen kannalta on tärkeää, että keskustelemassa on erilaisen taustan omaavia henkilöitä, jotta laaja kuva tavanomaisesta arjesta erilaisissa kotitalouksissa muodostuu. Bradshaw ym. (2008) havaitsivat, 
että keskustelu yksinomaan pienituloisten kanssa supistaa keskustelua ja saattaa keinotekoisesti rajoittaa keskustelua välttämättömäksi katsotuista hyödykkeistä. Käytyjen keskustelujen pohjalta voimme todeta samoin, sillä vain määrättyä kotitaloustyyppiä edustavat taloudet ovat hyvin saman mielisiä eikä vaihtoehtoja tuoda yhtä monipuolisesti keskusteluun kuin erilaisia kotitalouksia edustavissa ryhmissä.

Tällä kertaa ryhmäkeskustelijat saatiin Tutkimustie Oy rekrytointiyrityksen kautta $^{4}$. Rekrytoinnin taustaksi kerrottiin, että olemme kiinnostuneita siitä, miten kuluttajien oman näkemyksen mukaan arki saadaan sujumaan kohtuullisesti ja mitä tavaroita ja palveluja siihen tarvitaan. Kerroimme tapaamisten aluksi, että keskusteluissa ja kotitehtävässä haetaan näkemyksiä ja kokemuksia arjesta ja sen sujumisesta sekä lopputuloksena yhteisymmärrystä sisällöistä. Kuluttajien ryhmäkeskustelut on litteroitu. Keskustelujen sisältöä on analysoitu etsimällä yhteisymmärrystä niistä arjen välttämättömistä tarpeista, toiminnoista ja hyödykkeistä, jotta tulee toimeen, voi ylläpitää terveyttä ja osallistua.

Ryhmäkeskustelujen ensimmäinen kierros järjestettiin helmi-maaliskuussa ja toinen toukokuussa 2017. Keskustelukierrosten välissä keskustelijat tekivät kotitehtäviä (ruokapäiväkirja ja hyödykelistojen arviointi), jotka he palauttivat toisella tapaamiskerralla. Keskustelijoiden sitouttamiseksi heille maksettiin lahjakorttina 90 euron palkkio.

Ryhmät koottiin Helsinkiin, Ouluun, Mikkeliin ja Hämeenlinnaan. Helsingissä kokoontui kaksi ryhmää ja kullakin muulla paikkakunnalla yksi. Helsingin ryhmistä oli toisessa vain lapsiperheitä ja toisessa muita perhetyyppejä edustavia kuluttajia. Muilla paikkakunnilla kaikki perhetyypit kokoontuivat samassa ryhmässä.

Keskusteluihin ilmoittautuneet osallistuivat niihin varsin tunnollisesti. Ensimmäiseen keskustelukierrokseen osallistui yhteensä 36 keskustelijaa, joista naisia 20 ja miehiä 16. Helsingin kahdessa ryhmässä oli yhteensä 16 keskustelijaa, Oulussa 7, Hämeenlinnassa 8 ja Mikkelissä 5. Keskustelijat olivat iältään 20-71-vuotiaita, keskimäärin 42,7-vuotiaita. Yksin asuvia heistä oli 10 (3 miestä ja 7 naista), puolison kanssa kaksin asuvia 11 ja lapsiperheen vanhempia 15, joista 5 oli yksinhuoltajia. Taloudessa asuvien lasten iät vaihtelivat alle 2-vuotiaasta lukioja ammattikouluikäisiin asti. Lapsiperheiden koko vaihteli kahdesta seitsemään. Puolet talouksista oli oman ilmoituksensa mukaan keskituloisia, 13 heikkotuloisia ja 5 oli hyvätuloisia. Kaikki hyvätuloiset olivat Helsingin ryhmissä.

Toiselle keskustelukierrokselle osallistui yhteensä 34 henkilöä, jotka kaikki myös täyttivät kotitehtävänä olleet hyödykelistat ja ruokapäiväkirjat. Keskusteluista jäi pois kolme ensimmäisiin keskusteluihin osallistunutta henkilöä, mutta mukaan tuli yksi, joka ei päässyt ensimmäiselle kierrokselle. Tavoite

4 http://www.tutkimustie.fi/ 
eri-ikäisistä ja erilaisen taustan omaavista keskustelijoita toteutui hyvin ja keskustelijat edustivat monipuolisesti erilaisia viiteryhmiä kuten ryhmäkeskustelijoiden taustatietoja kuvaava Taulukko 1 osoittaa.

Taulukko 1. Ryhmäkeskustelijoiden taustatiedot.

\begin{tabular}{|c|c|c|}
\hline Sukupuoli & 1. kierros & 2. kierros \\
\hline mies & 16 & 14 \\
\hline nainen & 20 & 20 \\
\hline \multicolumn{3}{|l|}{ Kotitaloustyyppi } \\
\hline yksinasuva & 10 & 11 \\
\hline pari & 11 & 9 \\
\hline kahden huoltajan lapsiperhe & 10 & 10 \\
\hline yhden huoltajan lapsiperhe & 5 & 4 \\
\hline \multicolumn{3}{|l|}{ Ikä, vuotta } \\
\hline alle 40 & 15 & 15 \\
\hline $40-59$ & 14 & 13 \\
\hline yli 60+ & 7 & 6 \\
\hline \multicolumn{3}{|l|}{ Pääasiallinen toiminta } \\
\hline työssä & 21 & 20 \\
\hline työtön & 6 & 6 \\
\hline eläkeläinen & 7 & 7 \\
\hline opiskelija & 2 & 1 \\
\hline \multicolumn{3}{|l|}{ Tulokuvaus } \\
\hline heikkotuloinen & 13 & 10 \\
\hline keskituloinen & 18 & 19 \\
\hline hyvätuloinen & 5 & 5 \\
\hline Yhteensä henkilöitä & 36 & 34 \\
\hline
\end{tabular}

\section{Viitebudjettikotitaloudet}

Viitebudjetit voidaan laatia henkilöiden iän, elinvaiheen tai kotitaloustyypin mukaan. Esimerkiksi Ruotsissa on henkilöittäin laaditut viitebudjetit, jotka koostuvat henkilökohtaiset tavarat sisältävästä osasta ja kotitalouden yhteisestä osasta, jossa ovat talouden yhteisessä käytössä olevat tuotteet (Konsumentverket 2018).

Suomessa on päädytty laatimaan budjetit kotitalouskohtaisesti. Esimerkkitaloudet edustavat tavanomaisia, erikokoisia kotitalouksia Suomessa. Viitebudjetit laadittiin tällä kertaa kaikkiaan 13 erilaiselle kotitaloudelle. Viitebudjettitaloudet ovat neljä erilaista yksin asuvien taloutta, kolme erilaista 
lapsetonta paria ja neljä erilaista kahden huoltajan lapsiperhettä sekä kaksi yhden huoltajan taloutta, joissa äiti on huoltajana. Aiempaan verrattuna uusia viitebudjettitalouksia on 4 .

Viitebudjettitalouksien kuvaukset (aiemmat 9 ja uudet* $4 \mathrm{kpl}$ ):

1. yksin asuva alle 45-vuotias nainen (työssä)

2. yksin asuva alle 45-vuotias mies (työssä)

3. yksin asuva yli 65-vuotias nainen (eläkkeellä)

4. yksin asuva yli 65-vuotias mies (eläkkeellä)

5. *yli 50-vuotias pari (työssä, ei kotona asuvia alle 18-vuotiaita lapsia)

6. pari, jossa yli 50-vuotias työssä käyvä nainen ja yli 65-vuotias eläkkeellä oleva mies

7. *eläkkeellä oleva pari (molemmat yli 65 vuotta)

8. *yksinhuoltaja-äiti ja 3-vuotias tyttö

9. yksinhuoltaja-äiti, 10-v. poika ja 13-v. tyttö (yhden huoltajan perhe)

10. *äiti, isä ja 2 alle kouluikäistä lasta: poika $2 \mathrm{v}$ ja tyttö $6 \mathrm{v}$ (pikkulapsiperhe)

11. äiti, isä, 4-vuotias poika ja 10-vuotias tyttö (lapsiperhe)

12. äiti, isä, kaksi teini-ikäistä: 14-v. tyttö ja 16-v. poika ja (teiniperhe 4 henkilöä)

13. äiti, isä, kolme teini-ikäistä: 10-v. poika, 15-v. poika ja 17-v. tyttö (teiniperhe 5 henkilöä)

Yli 65-vuotiaiden oletettiin olevan eläkkeellä ja muiden aikuisten työelämässä. Työelämään osallistuminen vaikuttaa ruokabudjettiin ja joukkoliikenteen säännölliseen käyttöön. Perheissä on eri-ikäisiä lapsia: yhdessä esimerkkitaloudessa kolme 10-17-vuotiasta, yhdessä yksi leikki-ikäinen ja muissa talouksissa kaksi lasta. Eri-ikäisten lasten yksilölliset kustannukset on arvioitu erikseen, jotta niitä voidaan hyödyntää esimerkiksi vain yhden lapsen tai useampi lapsisten perheiden kustannuksia arvioitaessa (ks. luku 5.2).

\section{Hyödykkeiden ryhmittely}

Viitebudjettien hyödykkeet on ryhmitelty aiempien viitebudjettien tapaan toimintopohjaisesti seuraaviin pääryhmiin:

1. Ruoka ja juoma

2. Vaatteet*, kengät*

3. Tietoliikenne (laitteet* ja käyttömaksut) ja viihde-elektroniikka

4. Kodin tavarat ja laitteet (kodinkoneet*, astiat*, tekstiilit*, huonekalut*, tarvikkeet...) 
5. Terveys, hygienia ja kauneuden hoito

6. Vapaa-aika ja harrastukset

7. Asuminen (vuokra, erillinen erä, suuri alueellinen vaihtelu)

8. Liikenne (erillinen erä, alueellinen vaihtelu)

*kuluminen

Ryhmät noudattavat pääpiirteissään kulutustutkimuksessa käytettyä kansainvälistä hyödykkeiden yksilöllisen kulutuksen toimintopohjaista COICOP-luokittelua (Classification of Individual Consumption by Purpose) ${ }^{5}$, jossa hyödykkeet on ryhmitelty 12 pääryhmään. Viitebudjetissa joitakin ryhmiä on yhdistetty ja joitakin jätetty lähes kokonaan pois (alkoholijuomat ja tupakka sekä koulutus). Yksityiskohtaisemmat kuvaukset viitebudjetin tuoteryhmistä on esitetty luvussa 4 ja yksityiskohtaiset hyödykelistat (hyödykekorit) on koottu liitteisiin 1 ja 2.

\section{Periaatteet viitebudjettien laadinnassa}

Johtavana periaatteena viitebudjettiin sisältyviä hyödykkeitä valittaessaja hyväksyttäessä on, että tarpeellisten hyödykkeiden tulee sujuvoittaa toimintoja tai elämistä tämän päivän yhteiskunnassa, tai niitä tarvitaan sosiaalisten suhteiden ylläpitämiseen tai yhteiskunnalliseen osallistumiseen (vrt. CREDOC 2014; Davis ym. 2015). Hyödykekorien rakentamisen pohjana ovat olleet aiempien Suomessa laadittujen viitebudjettien tuotelistat (Lehtinen ym. 2010; Lehtinen \& Aalto 2014). Kevään 2017 ryhmäkeskustelijat päivittivät tuotteita aiempiin tuotelistoihin kotitehtävässään. Heitä opastettiin pohtimaan oman kotitaloutensa kaltaisen talouden tarpeita. Osallistujat arvioivat kunkin hyödykkeen tarpeellisuuden asteikolla: välttämätön, tarpeellinen ja ei-tarpeellinen. He myös lisäsivät listalle sieltä puuttuvia, välttämättöminä pitämiään hyödykkeitä. Hyödykekorien sisältöä käsiteltiin toisella ryhmäkeskustelukerralla ja haettiin ryhmien yhteistä näkemystä. Koriin jäivät ne tuotteet, jotka kuluttajat katsoivat tarpeelliseksi arjen sujumisen kannalta ja joista he olivat yhtä mieltä.

Mikäli selvää yhteistä näkemystä ei syntynyt, sisällön määrittelyssä käytettiin apuna aiempia hyödykeluetteloita, tutkimusta sekä asiantuntijaryhmän näkemyksiä. Kuluttajat kokivat erityisen vaikeaksi kertakäyttöisten tuotteiden kappalemäärien määrittelyn. Lukumäärien ja tuotteiden käyttöikien arvioinnin pohjana käytimme aiheeseen liittyviä tutkimuksia ja edellisten viitebudjettien

5 ks. esim. http://www.stat.fi/meta/luokitukset/coicop/o11-2013/index.html 
hyödykeluetteloita. Kestävien tuotteiden käyttöiät on määritelty suhteellisen pitkäksi, koska mukaan valitut tuotteet ovat melko laadukkaita, eikä niitä viitebudjetin periaatteiden mukaisesti vaihdeta uusiin ennen kuin ne ovat käyttökelvottomia.

\section{Ruokabudjetin laadinta}

Aiempien viitebudjettien (2010 ja 2013) tapaan tässä päivityksessä ruokabudjettien laadinnassa on hyödynnetty Terveyden ja hyvinvoinnin laitoksen Finelielintarvikkeiden koostumustietopankin $(2018)^{6}$ ruokamääriä, mittoja ja reseptejä. Olemme laatineet esimerkkiruokalistat kahdelle viikolle (Liite 3). Ruokalistojen pohjana ovat olleet keskusteluihin osallistuneiden ruokapäiväkirjat, käydyt ryhmäkeskustelut sekä suomalaiset ravitsemus- ja ruokasuositukset. Arkisin päivittäin nautittuja aterioita on viisi: aamiainen, kaksi lämmintä ateriaa ja kaksi välipalaa. Viikonloppuisin on neljä ateriaa, jolloin syödään yksi lämmin ateria aamiaisen, välipalan ja iltapalan lisäksi. Raaka-aineiden ja ruokien hinnat kerättiin helmikuussa ja maaliskuussa 2018 ja tarkistettiin elokuussa 2018. Tarjoushintoja ei ole otettu mukaan. Tarjousten hyödyntäminen tuo säästöjä ruokakustannuksiin liha-ja kalatuotteissa. Käyttökelpoisten tarjoushintojen kerääminen budjettiin ja sesonkien huomioiminen on pulmallista kuukausi- ja vuositasolla. Kaikki hinnat kerättiin K-ryhmän ja S-ryhmän internetsivustoilta (K-ruoka.fi ja Foodie.fi).

Ruokakustannukset on laskettu aterioittain kotitalouden jäsentä kohden. Kunkin ruokalajin reseptin pohjalta on laskettu tarvittavien raaka-aineiden määrä, hinnoiteltu ateria, laskettu talouden jäsenen energian saanti kyseisestä ateriasta, ja sen hinta. Laskelmissa on mukana juhlapäiviin (esimerkiksi joulu, pääsiäinen ja juhannus) sekä lasten juhliin varautuminen siten, että kotona valmistettavien kuukauden aterioiden kustannuksiin on lisätty 10 prosenttia. Sen vaikutuksesta kuukauden ruokakustannukset nousevat 3-11 euroa taloudesta riippuen. Kahden viikon jaksossa on laskettu ruokabudjettiin kuusi työpaikkalounasta, yhden kerran joko noutoruokaa kotiin tai ulkona ateriointi, ja kaikki muut ateriat valmistetaan kotona. Budjetteihin on varattu kaikille talouksille rahaa 10-11 euroa henkilöä kohden kodin ulkopuolella ateriointiin tai noutoruokaan joka toinen viikko. Ruoanvalmistuksessa syntyvän hävikin osuudeksi on huomioitu viisi prosenttia kuten aiemminkin (kuoret, luut, siemenet yms.).

6 Fineli (2018) Fineli-elintarvikkeiden koostumustietopankki. Saatavilla: https:// fineli.fi/fineli/fi/index. 


\section{Tavaroiden ja palveluiden laskentaperiaatteet ja hinnoittelu}

Yksityiskohtaiset hyödykelistaukset tarvitaan, jotta viitebudjetti voidaan hinnoitella realistisesti. Hyödykkeiden hinnat poimittiin pääasiassa keväällä 2018 hypermarkettien ja muiden liikkeiden internetsivuilta sekä kuntien ja julkisen liikenteen toimijoiden internetsivuilta. Tilastokeskuksen nettisivuilta poimittiin asuntojen keskineliövuokrat.

Kestävät tuotteet valittiin keskihintaisten, suosittujen tuotteiden joukosta. Niiden oletettiin olevan laadukkaampia kuin edullisimmat tuotteet ja sen vuoksi pidempi-ikäisiä. Hintoina käytettiin ns. normaalihintoja, ei alennettuja hintoja, jotta eri puolilla maata ja eri ajankohtina olisi mahdollista hankkia tuotteita samalla hinnalla.

Kertakäyttöisistä tuotteista eli tavaroista, joiden kesto alle vuoden, laskettiin kappalemäärät vuodessa ja kerrottiin yksikköhinnalla. Palveluille määritettiin vuosittaiset käyttökerrat. Kestäville tavaroille, joilla on vuotta pitempi käyttöikä, laskettiin vuotuisen kulumisen arvo jakamalla hankintahinta käyttöiällä. Tämä laskennallinen hinta on siten säästöä tavaroiden uusimista varten. Viitebudjetin kustannukset on laskettu kuukautta kohden. 


\section{VIITEBUDJETIT ESIMERKKITALOUKSILLE HYÖDYKERYHMITTÄIN}

Seuraavassa esitämme laatimamme viitebudjetit 13 erilaiselle kotitaloustyypille kulutusmenoryhmittäin. Ryhmäkeskustelujen ja muun tutkimuksen ohella käytössämme on ollut Tilastokeskuksen vuoden 2016 kulutustutkimusaineisto.

\subsection{RUOKA}

Riittävän ravinnon saanti on ihmisille välttämätöntä elintoimintojen ylläpitämiseksi ja hyvinvoinnin edistäjä. Riittävä ravinnon saanti tai ravintosuositukset eivät yksin määritä hyvää ja kohtuullista ruokaa ja sen laatua, sillä ruokaan liittyy kulttuurisia ja sosiaalisia merkityksiä (Ruokatieto 2009). Käytettävissä olevat tulot vaikuttavat ruoan valintaan, mutta myös ruoan terveellisyydellä, maulla, mainonnalla ja valmistustavalla on vaikutusta (Mäkelä 2002).

Tuoreimmat ravitsemussuositukset ovat vuodelta 2014. Valtion ravitsemusneuvottelukunta (VRN; Evira 2014) korostaa raportissaan ruokavalion kokonaisuuden ja terveyden välistä yhteyttä. Ravitsemussuositukset koskevat sekä ruokaa että ravintoaineita. Ruokasuositukset koskevat ruoka-aineryhmiä, kuten liha, maitovalmisteet tai viljavalmisteet. Ravitsemusneuvontaa varten laaditut ruokakolmio ja lautasmalli havainnollistavat eri ruoka-aineiden suhteellisia osuuksia terveyttä edistävässä ruokavaliossa ja ne pohjautuvat ruokasuosituksiin. Ravitsemusneuvottelukunnan (Evira 2014) suosittelemassa ruokakolmiossa kolmion pohjan muodostavat kasvikset ja hedelmät. Ateria-ajat ja tottumukset ovat pitkälti kulttuurisidonnaisia ja yksilöllisiä. Ravitsemussuosituksissa korostetaan myös säännöllistä ateriarytmiä. Sen vuoksi päivittäin pitäisi syödä säännöllisin väliajoin aterioina aamupala, lounas ja päivällinen sekä tarvittaessa 1-2 välipalaa. Säännöllinen ateriarytmi auttaa syömään kohtuullisesti yksittäisillä aterioilla ja vähentää houkutusta naposteluun.(Evira 2014.)

Ruoka kulutetaan suhteellisen nopeasti sen ostamisesta tai hankkimisesta. Ruokamenot ovat kustannuserä, jota taloudet käsittelevät päivittäin ja viikoittain. Ruokamenoihin voi vaikuttaa nopeasti, kun valitsee tarjoustuotteita tai valmistaa ruoan edullisista raaka-aineista. Taloudellisesti haavoittuvassa asemassa eläville ihmisille syntyy helposti tilanteita, joissa rahat eivät riitä ruokaan muiden välttämättömien kulujen jälkeen, ja silloin ruoasta joudutaan tinkimään (Silvasti 2011). On havaittu, että pienituloiset valitsevat ruokaa taloudellisin perustein: kaupan 
omia merkkejä, isoja pakkauskokoja ja ei-korkealaatuisia tuotteita (Kaufman ym. 1997). Pienituloiset suosivat tyypillisesti "edullisia kaloreita" eli energiatiheitä ja edullisia elintarvikkeita. Tällaisissa ruokavalinnoissa korostuvat prosessoidut, paljon sokeria ja rasvoja sisältävät ruoat. Pienituloiset syövät kasviksia ja hedelmiä hyvätuloisiin verrattuna vähemmän. (Lindblom 2017.) Lindblom (2017) havaitsi, että Suomessa tuloluokkien väliset erot ruokavalinnoissa ovat kaventuneet. Suomalaisten ruokatottumukset ovat muuttuneet viimeisten vuosikymmenien aikana monipuolisemmiksi ja kansainvälisemmiksi, ja myös tarjontaa on enemmän. Tarjolla on etnisten keittiöiden tuotteita, pitemmälle prosessoituja ruokia ja uusia raaka-aineita muualta maailmasta (ks. Aalto ja Peltoniemi 2014).

Suomessa on kattavasti järjestetty työssäkäyvien lounasruokailu sekä lasten ruokailu päivähoidossa ja kouluissa. Tuoreessa Terveyden ja hyvinvoinninlaitoksen (Raulio ym. 2018) kartoituksessa kuitenkin ilmeni, että koululaiset eivät osallistu koululounaalle kaikkina päivinä tai eivät ota kaikkia lounaaseen kuuluvia aterianosia. Päivän ravinnontarpeesta koululounas kattaa noin kolmanneksen, mutta vain harva lapsi söi tuon suosituksen mukaisesti (Raulio ym. 2018).

Tässä päivityksessä on uudistettu esimerkkiruokalistat, kerätty hinnat ja laadittu niiden pohjalta laskelmat esimerkkitalouksille. Periaatteena on ollut laatia terveellisiä, edullisia, tavanomaisia ruokia sisältäviä ruokalistoja, jotka pyrkivät noudattamaan suomalaisia ravitsemussuosituksia. Ruokapäiväkirjoja on käytetty hyväksi tarkastelemalla kuluttajien valmistamia ja nauttimia ruokia sekä päivittäistä ruokarytmiä. Kuluttajat kirjasivat ruokapäiväkirjoihin päivittäin syömänsä ateriat, valmistustavat ja ruokailupaikan. Ruokalistojen (Liite 3) ruokalajit on poimittu ruokapäiväkirjoista. Niihin on lisätty tuoreita kasviksia sekä vähennetty lihan osuutta lisäämällä kasviksia ja vihanneksia ruokalajeihin. Ruokalistat on pyritty laatimaan siten, että ruoan hävikkiä olisi vähän. Sen vuoksi samaa ruokaa tai sen osia on tarjolla muilla aterioilla. Useamman henkilön perheessä tarkka raaka-aineiden käyttö ei ole ongelma. Sen sijaan yhden henkilön taloudessa pienempien pakkauskokojen hankinta lisää kustannuksia, koska raaka-aineet ovat edullisempia suuriin pakkauksiin pakattuina kuin pienissä tai yksittäin pakatuissa. Palvelutiskiltä ostettaessa kilohinta on yleensä korkeampi kuin valmiiksi pakattuna, mutta siitä voi ostaa haluamansa määrän tuotetta. Energiantarve on huomioitu iän ja sukupuolen mukaan esimerkkitalouksien jäsenille aterioittain. Taulukossa 2 on esimerkkilaskelmiemme pohjana olevat päivittäiset energiantarpeet. 
Taulukko 2. Ruokakustannusten perustana olevat päivittäiset energiantarpeet eri-ikäisille henkilöille sukupuolittain (Valtion ravitsemusneuvottelukunta 2014).

\begin{tabular}{|lll|}
\hline Ikä, vuotta & $\begin{array}{l}\text { Tytöt/naiset } \\
\text { Energiantarve } \\
\text { MJ/vrk (kcal/vrk) }\end{array}$ & $\begin{array}{l}\text { Pojat/miehet } \\
\text { MJ/vrk (kcal/vrk) }\end{array}$ \\
\hline $2-5$ & $5,0(1195)$ & $5,0(1195)$ \\
\hline $6-9$ & $6,9(1650)$ & $6,9(1650)$ \\
\hline $10-13$ & $8,6(2055)$ & $9,3(2220)$ \\
\hline $14-17$ & $9,8(2341)$ & $11,8(2820)$ \\
\hline $18-30$ & $9,4-10,5(2245-2508)$ & $11,7-13,2(2795-3153)$ \\
\hline $31-60$ & $8,8-9,9(2102-2365)$ & $11,0-12,4(2627-2962)$ \\
\hline $61-74$ & $8,1-9,1(1935-2174)$ & $9,7-10,9(2317-2607)$ \\
\hline
\end{tabular}

Päivittäinen energian saanti on laskettu eri aterioiden yhteissummana. Laskelmissa olemme huomioineet aikuisten ja teinikäisten lasten aamiaisen energiantarpeeksi 380-450 kcal, lounaan 720-930 kcal, välipalan 320-430 kcal, illallisen 450-66o kcal ja iltapalan energiantarpeeksi $240-350$ kcal. Alle 10-vuotiailla lapsilla energiansaanti on seuraava: aamiainen 150-300 kcal, lounas 400-550 kcal, välipala $200 \mathrm{kcal}$, illallinen $280-400 \mathrm{kcal}$ ja iltapala 150-200 kcal. Aterioiden energiansaanti ei ole joka päivänä täysin sama, mutta kahden viikon jaksolla toteutuu iän ja sukupuolen mukainen energiantarve keskimäärin. Emme ole huomioineet erityisruokavalioiden (laktoositon, keliakia jne.) kustannuksia, minkä noudattaminen lisää ruokamenoja.

Työssäkäyvillä ruokabudjettien pohjana on arkisin aamiainen, yksi välipala, illallinen ja iltapala. Aamiainen sisältää kaikilla talouksilla puuron tai jogurtin, marjasosetta, leipää, leikkeleen, kahvia/teetä, kasviksen ja hedelmän. Viikonloppuisin aterioita on neljä: runsas aamiainen, välipala, yksi lämmin ateria ja iltapala. Viikonloppuisin lapsiperheissä on keskustelijoiden mukaan tyypillistä nukkua pitempään, joten aamiainen syödään myöhemmin kuin arkena ja sen lisäksi nautitaan yksi pääateria, joko lounas tai illallinen. Loma-aikana kotona valmistettuja ja syötyjä aterioita on viisi, joten kahdelle kuukaudelle vuodessa on laskettu kotona valmistettujen lounaiden kustannukset illallisten ja välipalojen lisäksi. Iäkkäillä ruokabudjettiin on laskettu aamupala, lounas, välipala, illallinen ja iltapala. He 
valmistavat kaiken ruoan kotona. Kaikille talouksille on varattu rahaa ulkona syömiseen kaksi kertaa kuukaudessa noin 10 euroa aikuista ja teinikäistä lasta kohden. Alle 10-vuotiaille varattu raha on alle puolet aikuisen summasta.

Vaikka rahasta on tiukkaa, kuluttajat katsoivat, että olisi mukava lounastaa työkavereiden kanssa ainakin muutaman kerran viikossa. Kotona valmistettu lounas on edullinen verrattuna henkilöstöravintolan tarjoamaan lounaaseen. Lounaan nauttiminen henkilöstöravintolassa on Suomessa tyypillistä, sillä lähes puolet niistä, joilla on mahdollisuus lounastaa henkilöstöravintolassa, osallistuvat siihen (Aalto \& Heiskanen 2011; Vikstedt ym. 2012). Jos kotoa ei tuoda eväitä, eikä aterioida henkilöstöravintolassa, muutamat keskustelijat kertoivat ostavansa työpäivänä lähikaupan palvelutiskiltä ruokaa tai lämmittivät kaupan valmisruokia työpaikalla. Tuettu lounasruokailu on viitebudjeteissa, koska keskustelijat katsoivat lounastamisen olevan tärkeä sosiaalinen elementti työpaikalla yhteenkuuluvuuden lisäämiseksi. Lounaan verotusarvoa pidettiin korkeana ja keskustelijat kritisoivat hinnan ja laadun välistä suhdetta. Kaikilla ei ole myöskään mahdollisuutta hyödyntää työpaikan lounastarjontaa etätöiden tai matkatöiden vuoksi. Kompromissina työpaikan lounaan kalleudelle ja mahdollisuudelle hyödyntää sitä, olemme laskeneet tuetun lounaan hinnan kolmelle työpäivälle ja kahtena päivänä syödään lounaalla kotoa tuotuja eväitä. Lapset saavat lounaan päivähoidossa ja koulussa. Työssäkäyvien lounasruokailun hintana on käytetty lounasruokailun verotusarvoa, joka oli 6,50 euroa vuonna 2018 (5,50 e vuonna 2010 ja 5,90 e vuonna 2013) (Verohallinto 2017).

Taulukoissa 3 ja 4 esitetään ruokakustannukset kuukaudessa. Ruokakustannuksissa on mukana kaikki syöty ruoka, johon on käytetty rahaa. Ruokakustannuksia ei ole muissa hyödykeryhmissä, esimerkiksi vapaa-ajassa. Kotona valmistettuun ruokaan sisältyvät aamiainen, välipala, illallinen ja iltapala sekä työssäkäyvien kotona valmistettu ruoka lounasevääksi kahtena päivänä viikossa 10 kuukauden aikana. Loma-aikana (2 kk) valmistetaan kaikki ateriat kotona. Yksin asuvilla kotiruoka tuo säästöä ruokabudjettiin loman aikana. Lapsiperheillä, etenkin teini-ikäisten lasten talouksissa, kotona valmistettu lounas loma-aikana on edullinen verrattuna kodin ulkopuolella syötävään lounaaseen, mutta kokonaisuudessaan se ei tuo säästöä, sillä lounaaseen menevä rahamäärä kasvaa taloudessa, koska ruokaa on valmistettava suurempia määria ja useammalle, kun lapset eivät voi hyödyntää koulun tarjoamaa lounasta. Teini-ikäisten lasten energian tarve on yhtä suuri tai suurempi kuin aikuisilla. Esimerkiksi teinikäisten poikien energiantarve on suurempi kuin yli 30-vuotiaalla miehellä. Samoin on tytöillä ja naisilla ja yli 30-vuotiaan naisen ja 10-vuotiaan pojan energiantarve on lähes yhtä suuri. Kolmen lapsen ja kahden huoltajan esimerkkitaloudessa se tarkoittaa energiantarpeen näkökulmasta ruoan valmistamista viidelle aikuiselle. 
Taulukko 3. Ruokakustannukset yksin asuvilla ja pareilla vuonna 2018, e/kk.

\begin{tabular}{|c|c|c|c|c|c|c|c|}
\hline & $\begin{array}{l}\text { N alle } \\
45 v\end{array}$ & $\begin{array}{c}\text { M alle } \\
45 v\end{array}$ & $\begin{array}{l}\text { N yli } \\
65 v\end{array}$ & $\begin{array}{l}\text { M yli } \\
65 \mathrm{v}\end{array}$ & Pari & $\begin{array}{c}\text { Pari } \\
50+v \text { ja } \\
65+v\end{array}$ & $\begin{array}{c}\text { Pari } \\
65+v\end{array}$ \\
\hline $\begin{array}{c}\text { Kotona valmistettu arkena } \\
\text { e/kk (10 kk) }\end{array}$ & 170 & 202 & 158 & 184 & 372 & 336 & 346 \\
\hline Loma-aika e/kk (2 kk) & 198 & 234 & 158 & 184 & 428 & 416 & 346 \\
\hline $\begin{array}{l}\text { Työpaikka-lounaat } \\
\text { e/kk (10 kk) }\end{array}$ & 78 & 78 & 0 & 0 & 156 & 78 & 0 \\
\hline $\begin{array}{l}\text { Muu ulkona syöminen } \\
\text { e/kk (12 kk) }\end{array}$ & 20 & 22 & 20 & 20 & 40 & 40 & 40 \\
\hline YHTEENSÄ e/v & 3132 & 3526 & 2148 & 2460 & 6646 & 5495 & 4591 \\
\hline KESKIMÄÄRIN e/kk & 261 & 294 & 179 & 205 & 554 & 458 & 383 \\
\hline
\end{tabular}

N ja M alle 45: nainen alle 45 v. yksin asuva ja mies alle 45 v. yksin asuva

Pari: nainen ja mies yli 50v, ei kotona asuvia alle 18-v. lapsia; pari 50+ ja 65+:nainen yli 50v, mies yli 65v: pari 65+: nainen ja mies yli 65v;

Taulukko 4. Ruokakustannukset lapsiperheissä vuonna 2018, e/kk.

\begin{tabular}{|c|c|c|c|c|c|c|}
\hline & $\begin{array}{l}\text { YH-perhe, } \\
\text { yksi lapsi }\end{array}$ & $\begin{array}{l}\text { YH-perhe, } \\
\text { kaksi lasta }\end{array}$ & $\begin{array}{l}\text { Pikkulapsi- } \\
\text { perhe, kaksi } \\
\text { lasta }\end{array}$ & $\begin{array}{l}\text { Lapsiperhe, } \\
\text { kaksi lasta }\end{array}$ & $\begin{array}{l}\text { Teiniperhe, } \\
\text { kaksi lasta }\end{array}$ & $\begin{array}{l}\text { Teiniperhe, } \\
\text { kolme lasta }\end{array}$ \\
\hline $\begin{array}{c}\text { Kotona } \\
\text { valmistettu } \\
\text { arkena } \\
\text { e/kk (10 kk) }\end{array}$ & 242 & 472 & 512 & 558 & 698 & 846 \\
\hline $\begin{array}{l}\text { Loma-aika } \\
\text { e/kk (2 kk) }\end{array}$ & 288 & 592 & 612 & 670 & 864 & 1042 \\
\hline $\begin{array}{c}\text { Työpaikka- } \\
\text { lounaat } \\
\text { e/kk (10 kk) }\end{array}$ & 78 & 78 & 156 & 156 & 156 & 156 \\
\hline $\begin{array}{l}\text { Muu ulkona } \\
\text { syöminen } \\
\text { e/kk (12 kk) }\end{array}$ & 26 & 62 & 50 & 60 & 86 & 106 \\
\hline $\begin{array}{c}\text { YHTEENSÄ } \\
\text { e/v }\end{array}$ & 4086 & 7429 & 8518 & 9198 & 11304 & 13378 \\
\hline $\begin{array}{c}\text { KESKIMÄÄRIN } \\
\text { e/kk }\end{array}$ & 341 & 619 & 710 & 766 & 942 & 1115 \\
\hline
\end{tabular}

Lapsiperheiden kuvaukset: YH-perhe yksi lapsi: äiti ja 3-v. tyttö; YH-perhe kaksi lasta: äiti, 10-v. poika ja 13-v. tyttö; Pikkulapsiperhe, kaksi lasta: äiti, isä, poika 2 v ja tyttö 6 v; Lapsiperhe, kaksi lasta: äiti, isä, 4-v. poika ja 10-v. tyttö; Teiniperhe kaksi lasta: äiti, isä, teini-ikäistä: 14-v. tyttö ja 16-v. poika; Teiniperhe kolme lasta: äiti, isä, 10-v. poika, 15-v. poika ja 17-v. tyttö (ks. luku 3) 
Ruokabudjetit ovat alhaisemmat kuin mitä ne olivat edellisessä hintapäivityksessä vuonna 2015. Raaka-aineiden hinnat ovat hieman edullisemmat kuin aiemmin kaupparyhmien välisen kilpailun johdosta. Sen lisäksi budjettia alentaa työpaikkalounaiden väheneminen aiemmasta viidestä kerrasta kolmeen kertaan viikossa.

\section{Ruokapäiväkirjat ja keskustelut}

Kuluttajia pyydettiin pitämään ruokapäiväkirjaa 3-4 päivältä,joista vähintään yhden päivän piti sijoittua viikonloppuun. Vuonna 2010 pyysimme kuluttajia täyttämään koko viikon ruokapäiväkirjaa. Suurin osa piti päiväkirjaa neljä päivää ja päiväkirjat olivat täytetyt hyvin. Ruokapäiväkirjan palautti 32 kuluttajaa. Ruokapäiväkirja lähetettiin keskustelijoille ensimmäisen keskustelunjälkeenja sen täyttöä pohjustettiin ensimmäisessä keskustelussa. Kuluttajien pitämien ruokapäiväkirjojen antama informaatio tukee hyvin käytyjä keskusteluja ja konkretisoi talouksien käytäntöjä ja ruokarytmiä. Täyttäminen oli myös kuluttajille mukava kokemus, vaikka he ensin olivat epäileväisiä sitä kohtaan.

Ruokapäiväkirjoista nousi esiin kolme mielenkiintoista asiaa. Ensinnäkin, päiväkirjojen täyttäjät söivät pääsääntöisesti terveellisen aamiaisen. Ruokapäiväkirjojen mukaan puuron syönti aamulla on lisääntynyt merkittävästi vuodesta 2010. Jogurtti on toinen aamiaisvaihtoehto, vain kahvia aamiaiseksi ei juuri päiväkirjoissa ollut. Toinen muutos vuoteen 2010 on välipalarahkojen merkittävä yleistyminen välipalana tai iltapalana, mikä tulee esiin myös elintarvikkeiden kulutustilastoissa (Aalto 2018). Ruokapäiväkirjojen mukaan kaiken ikäiset kuluttajat syövät rahkoja. Erityistä suosikkia lounasruuaksi ja kotona valmistettavaksi ateriaksi ei ollut, mutta kana- ja pastaruokia syödään useita kertoja viikossa niin kotona kuin työpaikalla. Päivän välipala on rahka, jogurtti tai hedelmä, jonka nauttivat myös isommat lapset tullessaan koulusta ja ennen urheiluharrastuksia. Kolmas huomio on aikuisten pitkin päivää nauttimat makeiset. Aiemmin ei ole ruokapäiväkirjoissa ollut yhtä runsaasti makeisia kuin nyt. Ruokapäiväkirjoista ei paljastu syötyjen aterioiden tarkempi ravintosisältö. Niukka rasvojen saanti ei saisi kuitenkaan johtaa runsaaseen sokerin ja vähäkuituisen hiilihydraattien saannin lisääntymiseen (Evira 2014).

Valtion Ravitsemusneuvottelukunta (Evira 2014) korostaa raportissaan ruokavalion kokonaisuuden ja terveyden välistä yhteyttä. Keskustelijat olivat perillä ravitsemus- ja ruokasuosituksista. Osa pyrki seuraamaan niitä, muutama oli täysin vastaa niitä. Seuraavassa poimintoja keskusteluista: 
... meillä nyt ei ravintosuosituksia nïnkään silleen seurata noita virallisia, koska mä oon nïin laiska että mä en seuraa. Yritetään nyt kuitenkin silleen, että ei nyt ihan joka päivä tai ees joka viikkokaan sitä kylmää mikropitsaa syötäis...

Nainen 4Ov, lapsiperhe

Nii. Mut jos sitten, jos ei se sillä hetkellä oo se lautanen (lautasmalli) sen näkönen, et se kokonaisuus kuitenkin sitten päivän mittaan tai vaikka useamman päivän mittaan nii ois semmonen hyvä.

Nainen $67 v$, yksinasuva

Pyrin välttään näitä virallisia ravitsemussuosituksia. Koska ne on ihan puuta heinää.

Mies $46 v$, lapsiperhe

Ensimmäisessä keskustelussa käytiin läpi ruokaan liittyviä yleisiä periaatteita ja miten ruokailu on talouksissa järjestetty. Keskustelijat korostivat säännöllistä ateriarytmiä ja monipuolista ruokaa:

No sïs mullakin ois just ehkä toi säännöllinen syömien ja mäkin teen sïs kotona lähes kaiken muun ruuan ja sillai aika monipuolisesti yritän syödä erilaisia ruoka-aineita ja sit sanottaisko sitä et mikä on välttämätöntä. Nïn jos mä ajattelisin mikä on ihan välttämätöntä nï̈ kyl just kaikilla tommosilla kuiva ja säilyketuotteilla pystyy varmaan syömään terveellisesti. Mut mä ajattelisin myös että semmoiset tuoretuotteet nïn kun kasvikset, hedelmät ja tommoset tuoreet proteïnilähteet ja tällaiset, et ne kuuluu sïhen sellaiseen terveelliseen ruokavalioon. Ja mä syön siis kasvia ja kalatuotteita, et oon sillai vähentänyt lihan syöntiä. Mut en mä oo kokonaan kasvissyöjä.

Nainen $25 v$, yksinasuva

... mun mielestä ruuan pitää olla monipuolista. Kyllä täytyy olla hyvin monenlaista ravintoa joka päivä.

Nainen $67 v$, yksinasuva

Ruokapäiväkirjojen täyttäjät söivät pääsääntöisesti sekaruokaa, vaikkakin naisten ruoka oli enemmän kasvispainotteista kuin miehillä. Keskusteluissa nostettiin esiin kasvisruoan maku, mutta samalla niiden hinta satokauden ulkopuolella. Seuraavassa lapsiperheen edustaja kertoo kasviksien käytöstä: 
Ne (kasvikset) on tärkeitä ja nykypäivänä on valtavan hyviä, että talvenkin aikana. No ei oo tuoreita kasviksia kohtuuhinnoilla saatavissa. Nïn pakastetut kasviksetkin niin nehän toimii tosi hyvin. Ja käytännössä niïtä saa ympäri vuoden kaupasta. Se on tosi helppo lyyvä esimerkiksi keittoon nïn pussillinen tai kastikkeeseen niïtä kasviksia. Ne on tosi hyviä. Jos on vähänkään ylimääräistä rahaa nïn kattoo sen kotimaisen tai luomuvaihtoehon...

Mies 46v, lapsiperhe

Taloudelliset syyt näkyvät ruoan valmistuksessa ja aterioinnissa. Useimmat valmistavat kerralla sen verran ruokaa, että sitä riittää lämmitettäväksi myöhemmin. Nuori nainen kertoo:

...minulla on tapana laittaa ruokaa kerralla enemmän ja syödä samaa ruokaa usealla aterialla. En ole työssä tai opiskelemassa, joten ruokailen pääsääntöisesti kotona. Ruoan teko itse kotona on myös taloudellinen pakko, sillä minulla ei ole varaa syödä usein ulkona. Pyrin syömään monipuolisesti ja myös tuoretuotteita, vaikka kuivatuotteet ja säilykkeet ovatkin edullisempia. Syön kasvispainotteisesti (ei punaista lihaa tai kanaa ollenkaan, välillä kalaa). Kotona on helppo ylläpitää säännöllistä ruokarytmiä: aamupala, lounas, päivällinen, iltapala.

Nainen 25v, yksinasuva

Iltapäiväkahvi ja se kanssa nautittu rahka, hedelmä tai makeiset on ollut monelle vaikea hahmottaa välipalaksi. Ruokapäiväkirjoissa mainitaan vapaassa tekstissä neljä ateriaa, mutta edellä kuvattua välipalaa ei ole laskettu mukaan, vaikka se päiväkirjoissa on kirjattu ylös neljän muun aterian lisäksi. Myös keskusteluissa välipalat puhuttivat:

... meillä ainakin ne välipalat on monesti saattaa olla sitä itse ruokahetkeä nïn kun isommassa roolissa välillä ja mulla tota yks lapsista jo syö samaa ruokaa muun perheen kans ja toinen on vielä vauva. Niin kun ei oo ihan vielä vuotta niin ei voi syödä ihan samaa nün sitten sïhen menee tietenkin oma vaivansa ja rahansa, että sitten tekee tai ostaa sitten vauvalle sopivaa suolatonta ruokaa ... Et just, että jos ne välipalat syödään kotona niin sitten ne saa aika edullisesti. Nïin kun et on leipää ja hedelmiä ja näin. Mut sit kun ollaan liikenteessä monesti. Päivät saattaa olla semmoisii ruuhkaisia, et sit se välipala pitää syödä jossain matkalla niïn sit pitää ostaa näitä, et vaikka kaupasta jotain karjalanpiirakoita tai jotain. ....Et välipaloihin menee yllättävän paljon rahaa.

Nainen 3ov, lapsiperhe

Ravitsemuksella on vaikutusta monien sairauksien syntyyn (Evira 2014). Samaa mieltä ovat myös niin vuoden 2010 kuin tämän kertaiset ryhmäkeskusteluihin osallistuneet kuluttajat (Lehtinen ym. 2010). Monipuolisen ruoan lisäksi liikunta on keino ylläpitää omaa terveyttä: 
Nïn voin kyllä allekirjoittaa, että ruualla on valtava merkitys sïhen terveyteen sitten...., että jos niïn henk. kohtaisesti on toiminut erittäin hyvin...

Mies $40 v$, pariskunta

Must tähän kuuluu myös liikunta, että semmoinen itsehoidollinen puoli, et liikunta on ehkä tärkee kanssa, jos vaan sisua rïttää.

Nainen 65v, pariskunta

Ruokapäiväkirjojen täyttäjät söivät lounaan usein henkilöstöravintolassa ainakin sen täyttämispäivinä poissulkien etätyöläiset, eläkeläiset, työttömät ja kotona työskentelevät. Joillakin oli mahdollisuus syödä myös puuroaamiainen työpaikalla. Useimmat työssä olevat keskustelijat pitivät työpaikkaruokailua yhteisöllisenä hetkenä ja tauotuksen paikkana, kuten seuraavat sitaatit kuvaavat:

Mun pitää sanoo ite että mun mielestä todellakin [työpaikkalounas budjetissa] pitäis olla mukana vaik mä en sitä itse käytäkään. Mut sïs osaa ajatella vähän laajemmalla skaalalla kun kattoo vähän omaa napaansa pitemmälle et.

Mies, $28 v$, lapsiperhe

Mut sitte, mä tein mun edellises työpaikas sillee, että mä tosi usein otin just, jos oli kotoota jääny jotain yli, mut sit sä oot yksin siellä taukohuonees, kaikki muut on jossain syömäs, et sä tavallaan jäät siitä. Sehän on vähän, se on kans semmonen sosiaalinen hetki, et no nii, nyt meijän tiimi lähtee, lähetään lounaalle. Ja sit sä tavallaan jäät paitsi siitä kaikesta, mitä siel on juteltu.

Nainen $42 v$, lapsiperhe

Vuorotyö ja harrastukset vaikuttavat perheen ruokahetkiin, joillakin on hyvin harvoin yhteistä ruokailua muiden perheenjäsenten kanssa. Viikonloppuisin erityisesti lapsiperheissä herätään myöhemmin kuin arkena ja aterioita on sen vuoksi yksi vähemmän kuin arkena. Seuraavassa kuvausta viikonlopun aterioinneista lapsiperheissä:

No meillä varmaan ehkä viikonloppuna on se toinen ilta-ateria nïn se menee ehkä iltapalan yhteyteen, et me syödään nïn paljon runsaammin sit illalla muuten isompi ateria, et sit ei tartte oikeastaan iltapalaa. Sit lapsista ehkä nuorimmainen meiän tyttö on sit kotona. Pojat melkein menee omia menojaan, että me ei paljon käy kun päivällä syömässä ja sit ne herää nïn myöhään, et ei me aamiaista syödä ikinä yhtaikaa niitten kans. Sit mun mies on vuorotöissä, et monta kertaa on nïn, et sekin on viikonloput poissa, et sit se jää melkein et me tytön kans syödään sit keskenään ja pojat syö sit kun on.

Nainen $49 v$, lapsiperhe 
Joo kyl se varmaan joustavuus se viikonlopun avainsana on. Et saattaa se lounas sitten mennä sïhen iltapäivän puolelle ja sit tavallaan kuittautuu ehkä se yks ateria pois kokonaan siitä ohjelmasta. Et toki vaihtelee, et mitä on päivän aktiviteetti.

Mies, $34 v$, yksinasuva

\begin{abstract}
Alkoholista ja tupakasta keskusteltiin vilkkaasti. Tupakka oli nyt, kuten oli vuonna 2010, ehdottomasti tarpeeton. Tupakointi on kallista, epäterveellistä eikä kuulu viitebudjettiin. Alkoholista ei löytynyt yhtä selkeää kantaa. Alkoholi liittyy vapaaaikaan, vierailuihin ja viikonlopun viettämiseen. Seuraavassa pohdintaa alkoholista:
\end{abstract}

Meillä ei juoda ollenkaan alkoholia, eikä tupakkaa. Ei oo raivoraitista, mut ei vaan käytetä.

Mies $42 v$, lapsiperhe

Nïn kun ne käy siellä nïnku, ulkomailla se kulttuuri on erilaine, et siellä käydään nïnkun sivistyneesti pubissa seurustelemassa, kun täällä taas sitte se kulttuuri on nü̈ paljon erilainen. Et toki täälläkin tehdään sitä, mutta se just, mä ainakin ymmärsin ton pointin nünku, ... et kaikki suomalaiset ei käy joka viikko töitten jälkeen lasillisella. Et meillä on niïn erilaista...

Nainen $26 v$, pariskunta

Niin just tuo vapaa-aikajuttu sillai, et mun mielestä on vaikea sanoa, et jotenkin et alkoholi ja tupakka on nyt laitettu tohon tollai yhteen, et ei munkaan mielestä kukaan tarvi mitään röökirahaa välttämättä. Mut mä ajattelen alkoholin just semmoisena .... Se vois olla joku alkoholi kautta ulkona syöminen, et vois kerran kuussa mennä kavereitten kanssa ....jotain mitä sä nyt haluat sen illan aikana niin kun siellä ulkona tehdä.

Nainen 25v, yksinasuva

Tupakkaa ei ole viitebudjeteissa huomioitu, myöskään alkoholiin ei ole varattu rahaa kotiin ostettavaksi.

\title{
4.2 VAATETUS
}

Vaatteita tarvitaan erilaisiin tilanteisiin ja eri vuodenaikoja varten. Vaatteiden kestävyyteen vaikuttavat materiaali (tekstiilikuidut), tuotteen rakenne (mm. paksuus, tiiviys, kankaan sidosrakenne) ja valmistuksen huolellisuus (mm. saumat, saumavarat). Väljät vaatteet kestävät pidempään kuin tiukat. Vaatteen käyttöikää voi pidentää huoltamalla sitä hyvin. Mikäli vaatetta on helppo muuntaa ja korjata (esim. vetoketjun vaihto), myös se edistää pitkää käyttöikää. Monikäyttöinen vaate 
on usein tehokkaassa käytössä koko käyttöikänsä ajan. Esimerkiksi irrotettava vuori takissa mahdollistaa sen käytön eri vuodenaikoina. Lisäksi vaatteiden kestoikään vaikuttaa merkittävästi käytettävissä olevien vaatteiden määrä.

Kuluttajien omistamista vaatemääristä on vain vähän tietoja. Systemaattisimmin vaatteitaan ovat inventoineen käsityönopettajiksi opiskelevat. Vuonna 2012 opiskelijat omistivat keskimäärin yli 270 vaatetta (vaihtelu: 49-650) ja moni heistä koki, että omisti liikaa vaatteita. (ks. lähemmin Aalto 2014.) Lähes sama vaatteiden lukumäärä saatiin, kun kuluttajaohjelma Kuningaskuluttaja ${ }^{7}$ pyysi katsojia laskemaan omistamansa vaatteet vuonna 2014. Kyselyyn vastanneet noin 200 katsojaa omistivat keskimäärin 280 vaatetta. Huomattavaa on, että vaihtelu omistettujen vaatteiden lukumäärissä oli hyvin suuri (42-968). Osa kuluttajista (13 \%) tuli toimeen alle 100 vaatteella, kun tavanomaisimmin (51 \%) vaatteita omistettiin 100-300 ja joka viidennellä oli yli 500 vaatekappaletta. Kuningaskuluttajan vaatehaasteeseen vastanneista eniten vaatteita omistavat totesivat, että niitä kaikkia ei tarvita ja monet ylimääräiset vaatteet poistettiin inventoinnin yhteydessä vaatekeräyksiin.

Viitebudjetin on tarkoitus kattaa sellainen vaatevaranto, jota kuluttajat pitävät välttämättömänä. Asianmukaisten vaatteiden puute ei saisi rajoittaa arkea tai estää osallistumasta tavanomaisiin sosiaalisiin tilanteisiin. Seuraavat kommentit kuvaavat niin viitebudjettien ideaa kuin myös keskustelijoiden painotuksia vaatteiden valinnassa.

...just että on tavallaan kaikkiin eri vuodenaikoihin sopivat vaatteet. Mutta myös se, että ne on kestävät ja tarkoituksenmukaiset eikä sellaiset niinku, että fiiliksen mukaan ostelee, et no tänään tää-vaate-on-hyvä-tyyppisesti. Että on sellaiset mitkä käy monessa eri tilanteessa ja jotka kestää. On laadukkaita mieluummin kun sitten kertakäyttöisiä.

Mies 37v, lapsiperhe

Mä oon samaa mieltä tossa ... No ehkä T-paitoja voi ostaa halvalla. Mut jos ostaa oikeastaan jotain kenkiä sun muit, niï halvalla ei saa hyvää. Sillä että se halvat tulee hyvïn äkkiä maksaan paljon enemmän, kun tiät sä ostat joka viikko uudet kengät, kun ostat yhet kengätja sitten kestää kaks kolme vuotta.

Mies $38 v$, lapsiperhe

Joka kaudelle omat vaatteet, samaten kenkiä: kesä, talvi, syksy. Sitten vielä kuravaatteet, niitä pitää olla lapsilla monet kappaleet, koska pitää olla päiväkodissa ja kotona. Se ei riitä se yks vaatekerta.

Nainen 35v, lapsiperhe

7 Vaatehaaste (2015) http://yle.fi/aihe/artikkeli/2015/04/22/vaatehaasteen-tulokset. Haettu 28.4.2015. 
Juhlallisiin tilaisuuksiin tarvitaan juhlavaatteet. Yksimielisyys löytyi siitä, että miehillä pitää olla ainakin yksi tumma puku ja naisilla vähintään joku mekko tai leninki, jonka voi muuttaa asusteilla juhlavaksi.

Yks puku pitää miehellä ainakin miehellä olla, jos joutuu hautajaisiin, häihin mitä nyt onkaan... Mun mielestä tää on miehille tosi helppo. Se on miehillä aina tyyliin mustat suorat housut, musta puku, valkoinen paita ja joku kraga sïhen; that's it... Mä oon vetänyt samanlaisella juhlavaatekerralla varmaan joku neljä tai viis vuotta.

Mies 3ov, pariskunta

Yksvärinen vaikka nyt mekko, niin sitä sit pystyy muuttaan juhlaan tai työhön arkeen sopivaks. Et ehkä ite harrastan just sentyyppistä.

Nainen 54v, yksinasuva

Lasten vaatetarpeen ja vaatteiden keston arviointiin osallistui kevään 2017 ryhmäkeskustelijoista viisi vanhempaa, joilla kullakin 1-4 lasta. Lisäksi saimme lastenvaatteiden tarvearvioita erillisellä kyselyllä 13 äidiltä. Heillä oli yhteensä 17 lasta, joiden ikä oli 2-10 vuotta. Vaatteita koskevien keskustelujen lisäksi aikuisten vaatteiden määrää tiedusteltiin kotitehtävässä, johon tässä budjettipäivityksessä vastasi 10 miestä ja 13 naista. Kotitehtävän pohjana oli aiemman viitebudjetin (2013) vaatelistaus.

Vaatteiden käyttöiästä on vain vähän tutkittua tietoa ja vaatteiden käyttöikä voi vaihdella huomattavasti. Keväällä 2013 tehdyn kuluttajakyselyn perusteella useimpia vaatteita käytetään $3-5$ vuotta ennen kuin ne poistetaan omasta käytöstä. Sukkien ja ohuiden sukkahousujen käyttöikä on sitä lyhempi. Hameet, housut ja paidat ovat useimmilla käytössä yli 5 vuotta ja ulkovaatteet yli 7 vuotta. (Aalto 2014, 19-20.)

Arvio viitebudjetin sisältävien vaatteiden käyttöiästä perustuu em. kuluttajakyselyyn (Aalto 2014, 20), ensimmäisten (2010) viitebudjettien rakentamiseen osallistuneiden kuluttajien sekä asiantuntijoiden arvioihin. Arvioita on tarkistettu vuonna 2017 tehdyn kyselyn perusteella. Koska viitebudjetissa vaatteita on suhteellisen vähän, ne ovat tehokkaassa käytössä, jolloin niiden käyttöiät ovat keskimääräistä lyhemmät. Viitebudjeteissa työikäisten useimpien vaatteiden käyttöiäksi on arvioitu 3-5 vuotta. Käyttöiät on vuoden 2018 viitebudjetissa pitkälti pidetty aiempien viitebudjettien mukaisina, mutta joidenkin vaatteiden käyttöikää on pidennetty, koska niiden määrää lisättiin kuluttajien viimeisimpien tarvearviointien perusteella. Niin keskustelujen kuin myös tutkimusten (Aalto 2014, 19-20.) perusteella miesten vaatteet ovat tehokkaammassa käytössä kuin naisten vaatteet. Sen vuoksi miesten vaatteiden lukumäärä on suppeampi, mutta käyttöikä lähes sama kuin naisten vaatteilla. 
Eläkkeellä olevat käyttävät kyselyn (Aalto 2014) perusteella vaatteitaan pidempään kuin työssäkäyvät, joten heillä kestävimpien vaatteiden käyttöikiä on pidennetty noin vuodella työikäisten vaatteisiin verrattuna. Myös muiden maiden viitebudjeteissa eläkeikäisten vaatteiden on arvioitu olevan käytössä kauemmin kuin työikäisten (esim. CREDOC 2014; Davis ym. 2015).

Monet kuluttajat kertoivat, että he etsivät vaatteita käytettynä, etenkin lapsille ja myös alennusmyyntejä hyödynnetään. Niistä ei kuitenkaan aina löydä juuri sellaisia vaatteita kuin tarvitsee. Osa myös saa käytettyjä lastenvaatteita tutuilta ja saman perheen sisaruksilla vaatteita usein kierrätetään. Viitebudjetin näkökulmasta ne ovat säästömahdollisuuksia, joita on hankala peruslaskelmissa ottaa huomioon.

Osa keskustelijoista oli onnistunut lasten vaatteiden ostossa kirpputorilta ja osa nuorista etsii kirpputoreilta mieluisia vaatteita:

[Täällä] on myös tosi hyviä kirpputoreja, missä muun muassa vauvanvaatteet kiertää tosi hyvin. Aikuisen vaatteissa on vähän hankalampaa. Ei taho löytyä. Mutta meillä on vuojen ikäinen poika, nïn löytyy tosi hyvin ja ollaan ostettu. Ja sen ikäisille voi ostaa käytettynä vielä kengätkin. Kun ne on nün vähän aikaa käytössä, ne ei kulu. Mutta sitten, kun alakaa menneen vähänkään vanhemmaksi nïn se muotoutuu se kenkä jokkaisen jalalle. Nïn ei semmosta ei kyllä sitten ala ostaan.

Mies 46v, lapsiperhe

No sïs meillä on se yks alle $10 v$. Nïn turhaa ostaa uutena kasvavalle lapselle vaatteita. Mut et se on se kolomen vuoden aikaan ja joka vuosi joku rumba pittää käyvä ja kengät mieluummin uutena ja sïtä pittää lapsen ukki huolen. Se käy, metästää tarjouksesta uuvet kengät lapsenlapselle.

Nainen 4ov, lapsiperhe

Esimerkiks nyt tommoselle kaheksan-kymmenenvuotiaalle lapselle nïn ei löydy käytettynä vaatteita. Ne kuluttaa kyllä nïn loppuun.,

Nainen 35v, pariskunta

Aikuiset, joiden koko poikkesi keskimääräisestä vaatekoosta tai kokomitoituksesta, eivät löytäneet itselleen vaatteita käytettyinä. Erityisesti kookkaiden miesten oli vaikea löytää kirpputoreilta tarvitsemiaan vaatteita:

Mä en ainakaan oikein noita kirppislöytöjä montaakaan kertaa oo onnistunut tekemään. Kuitenkin vaatekoot on semmoiset, että hirveen huonosti löytyy.

Mies $28 v$, pariskunta 
Se on sïnä, kun miehet käyttää niïn kauan niitä vaatteita, nïn kerkee kulua ihan reikäsiks.

Nainen 7ov, pariskunta

Tota mä oon sen verran isokokoinen 193 senttinen. Nïn mä oon huomannut että muutaman kerran kun kirppiksellä käynyt nün on vähän huono valikoima ollut. Niin mulla se on aina uutena semmoista hyvänlaatuista. Mutta jossa merkki ei ole suurin osa sïtä hinnasta, eli semmoisia hyvälaatuisia mutta ei mitään tosi huippumerkkistä. Mä en tykkää merkkivaatteista. Kun sä maksat siitä yhestä logosta sit nün paljon.

Mies 27v, yksinasuva

Kirpputoreilla kiertelyä osa keskustelijoista piti lähinnä ajanvietteenä shoppailu-tyyliin:

Niin, ehkä kirppis on vähän semmonen, et kun tekee mieli, et olis kiva löytää semmonen tai tämmönen. Et nünkun sitä ei varsinaisesti välttämättä akuutisti tarvi, mutta et se on enemmänkin just sitä nïnkun ajanvietettä ja kiertelyä. Et harvemmin just se, et jos on tarve, niin sit se haetaan sieltä kaupasta, ja sieltä saa vaatteen.

Nainen 25v, pariskunta

Joo, mäkin luulen, että kirpputorilt, se oli just semmosta jotain ekstraa, kun siält löytää. Että ei nï̈nkun sïhen välttämättömään tarpeeseen. Nïn, kyl siihen tarvii melkein lähtee kaupasta hakeen. Mut sitten kun kirpputoreja kiertää, nïn siäl saattaa joskus löytää jotain kivaa, joka on sit semmosta, mitä ei välttämättä tarttiskaan, mutta kun saa halvalla...

Nainen 67v, yksinasuva

Ranskassa kuluttajien mielestä käytettyjen vaatteiden oston ja alennusmyyntien hyödyntämisen voi ottaa huomioon lasten vaatebudjeteissa. Siellä keskusteluissa päädyttiin siihen, että normaalihintaisten lasten vaatteiden yhteissummasta kolmas osan voi arvioida hankitun 30 prosentin alennuksella. Ranskan viitebudjetissa korostettiin myös muodin ja merkkivaatteiden merkitystä vaatehankinnoissa. (CREDOC 2014, 77-78.) Suomessa keskustelijat eivät tuoneet esiin muodin seuraamisen tarvetta, joten muoti tai vaihtelunhalu ei määritä viitebudjetin vaatehankintoja. Vaatteen kestoa tai vaatteen jäämistä pieneksi pidettiin ensisijaisina uusimistarpeen määrittäjinä.

Nyt kuten aiemminkin (Lehtinen ym. 2010), kuluttajat olivat sitä mieltä, että ketään ei voi velvoittaa hankimaan vaatteita käytettyinä tai alennusmyynneistä. Sopivien vaatteiden hankinta käytettynä tai alennuksella on sattuman varaista, joten sitä on vaikeaa ottaa budjetissa huomioon. Lisäksi käytettyjen vaatteiden 
myynti on siirtynyt nettiin ja sosiaaliseen mediaan, jolloin vaatetta ei näe tai voi sovittaa ennen ostoa. Viitebudjettilaskelmissa olisi myös vaikea hinnoitella käytettyjä vaatteita ja arvioida niille käyttöikää.

Laskelmien perustana ovat edelleen keskihintaiset, hypermarketista ostetut vaatteet. Näiden hintojen käyttämistä puoltaa myös se, että monet suomalaiset ostavat vaatteita marketeista. Kaupanliiton keväällä 2018 tekemän selvityksen ${ }^{8}$ mukaan noin 25 prosenttia vastaajista osti vaatteensa Prismoista, noin 21 prosenttia K-Citymarketeista ja kolmanneksi suosituimman sijan jakoivat Tokmanni ja nuorten naisten suosima Hennes \& Mauriz.

\section{Viitebudjetin vaatteet, kengät ja asusteet}

Viitebudjetteihin on sisällytetty ainoastaan nevaatteet ja sellainen määrä,jota kuluttajat pitävät välttämättömänä. Viitebudjetissa vaatteiden lukumäärä ei ole oleellinen vaan se, että niitä on riittävästi käytössä erilaisiin tilanteisiin. Budjetoitujen vaatteiden määrä on selvästi pienempi kuin mitä keskimäärin omistetaan (yli 270). Lähtökohta on, että budjetissa olevien vaatteiden oletetaan kestävän hyväkuntoisina arvioidun käyttöiän ajan, jonka jälkeen voi hankkia uuden. Toki kotikäytössä saattaa lisäksi olla vanhoja, huonokuntoisempia vaatteita. Liitteeseen 2 on koottu yksityiskohtaiset vaatelistat erikseen lasten, naisten ja miesten vaatteista lukumäärineen ja käyttöikineen.

Viitebudjetissa vaatetarpeet on ryhmitelty sukupuolen ja iän mukaan. Ikäluokat ovat 2-5-, 6-9-, 10-13-, 14-17-vuotiaat (teinit), työikäiset ja yli 65-vuotiaat. Osa lastenvaatekyselyyn vastanneista äideistä oli kirjannut hyvin runsaan vaatemäärän, osa taas hyvin niukan. Lasten vaatevarasto on hieman kasvanut verrattuna aiempaan viitebudjettiin, mutta suuria muutoksia ei ole. Kullekin lapsille on varattu noin 80 vaatetta. Vaatevaraston koonnissa on painotettu niukkaa, tehokkaassa käytössä olevaa varastoa, jolloin käyttöikä on lyhyt (useimmilla vaatteilla vuoden, joillakin 2 vuotta). Lasten vaatteiden käyttöikää rajoittaa se, että lasten kasvamisen vuoksi samat vaatteet mahtuvat saman lapsen päälle vain vähän aikaa.

Aikuisilla on useammanlaisia vaatteita kuin lapsilla, joten vaatteiden lukumäärä on hieman suurempi. Teini-ikäisille tytöillä on yhteensä noin 15 vaatetta ja jalkinetta vähemmän kuin työikäisille ja iäkkäille naisille, joilla niitä on noin 100 kappaletta. Koska teinikäiset vielä kasvavat, he joutuvat uusimaan vaatteitaan useammin kuin aikuiset. Sen vuoksi teinityttöjen perusvarasto on pienempi ja vaatteiden käyttöikä lyhempi kuin aikuisten naisten. Niin ikään teini-ikäiset

8 Verkossa: http://kauppa.fi/ajankohtaista/tiedotteet/miestenvaatteiden markkinat kasvavat globaalisti myoes suomessa 26593 (Haettu 29.5.2018) 
pojat tarvitsevat uusia vaatteita useammin kuin työikäiset ja eläkeikäiset miehet, joten teinipojille on budjetoitu noin 80 vaatekappaletta ja muille miehille noin 10 kappaletta enemmän. Naisten vaatteiden ja kenkien lukumäärä on hieman suurempi kuin aiemmassa viitebudjetissa. Teini-ikäisten tyttöjen ja poikien vaatteiden käyttöikä on viitebudjetissa keskimäärin hieman alle kolme vuotta, työikäisten naisten ja miesten vaatteilla neljä vuotta ja eläkeikäisten vaatteilla runsaat 4,5 vuotta. Suurimmat erot eri-ikäisillä ovat ulkovaatteiden kestoiässä (ks. Liite 2). Kuluttajien ja asiantuntijoiden kommenttien perusteella naisten ja miesten vaatteiden käyttöaikaa pidennettiin hieman aiempaan viitebudjettiin verrattuna (vrt. Lehtinen \& Aalto 2014).

Vaatetuskustannukset on laskettu aiempaan tapaan hypermarkettien keskihintaisten vaatteiden ja kenkien hinnoilla siten, että ostohinta on jaettu kestoiällä. Vaate- ja kenkäkulut vaihtelivat eläkeikäisten miesten 40 euron kuukausikuluista alakoululaisten 68 euroon. Lasten, naisten ja miesten vaatetuskulut on koottu ikäryhmittäin Taulukkoon 5 .

Taulukko 5. Vaatetuskustannukset viitebudjetissa eri-ikäisillä naisilla, miehillä ja lapsilla vuonna 2018, e/kk.

\begin{tabular}{|c|c|c|c|c|c|c|}
\hline Sukupuoli, ikä & $2-5 v$ & $6-9 v$ & $10-13 v$. & $14-17 \mathrm{v}$ & Työikäiset & $65+v$ \\
\hline Tyttö/nainen, vaatteet & 52 & 54 & 51 & 50 & 42 & 34 \\
\hline Tyttö/nainen, kengät & 10 & 14 & 16 & 12 & 14 & 11 \\
\hline Poika/mies, vaatteet & 52 & 54 & 49 & 53 & 35 & 31 \\
\hline Poika/mies, kengät & 10 & 14 & 16 & 14 & 10 & 9 \\
\hline $\begin{array}{l}\text { Tyttö/nainen, vaatteet } \\
\text { ja kengät, yht., } € / \text { kk }\end{array}$ & 61 & 68 & 67 & 62 & 56 & 45 \\
\hline $\begin{array}{l}\text { Poika/mies, vaatteet } \\
\text { ja kengät, yht., } € / \text { kk }\end{array}$ & 61 & 68 & 65 & 67 & 45 & 40 \\
\hline
\end{tabular}

Vaatetuskuluissa ei ole kovin suuria muutoksia verrattuna vuoden 2015 viitebudjettiin. Eniten ovat kohonneet lasten vaatteiden kustannukset. Niiden hinnat ovat nousseet eniten myös kuluttajahintaindeksin mukaan9. Lasten ja teini-ikäisten vaatekulut ovat kasvaneet hieman, sen sijaan työikäisten sekä eläkeikäisten naisten ja miesten vaatekulut ovat pysyneet lähes ennallaan. Iäkkäiden naisten ja miesten

9 Tilastokeskus, Kuluttajahintaindeksi 2013 - 2015. http://tilastokeskus.fi/til/khi/index.html 
kenkäkuluja kasvattavat hieman kenkiin kiinnitettävät liukuesteet, joita pidettiin tarpeellisina ehkäisemään liukastumisia ja niistä aiheutuvia vammoja ja suuria sairauskuluja.

Aiemmasta viitebudjetista poiketen laukut, kassit, lompakot ynnä muut vastaavat tuotteet on tässä laskettu talouskohtaisesti (Liite 1). Niiden kustannukset vaihtelevat yksin asuvien miesten kahdesta eurosta viisihenkisen lapsiperheen 12 euroon kuukaudessa. Taulukon 5 lasten, naisten ja miesten vaatekulujen perusteella on kullekin kotitaloudelle laskettu yhteen vaate- ja kenkäkulut ja siihen on lisätty kotitalouskohtaiset kassien, laukkujen, lompakoiden ym. kulut (Liite 1) ja ne on koottu Taulukkoon 6.

Taulukko 6. Vaatteiden, kenkien ja asusteiden kustannukset viitebudjetissa kotitaloustyypeittäin vuonna 2018, e/kk.

\begin{tabular}{|lcccc|}
\hline & $\begin{array}{c}\text { Vaatteet, } \\
\mathbf{\ell / k k}\end{array}$ & $\begin{array}{c}\text { Kengät, } \\
\mathbf{\ell / k k}\end{array}$ & $\begin{array}{c}\text { Laukut, } \\
\text { lompakot } \\
\text { yms., } \mathbf{\ell} / \mathbf{k k}\end{array}$ & $\begin{array}{c}\text { Yhteensä, } \\
\mathbf{\ell} / \mathbf{k k}\end{array}$ \\
\hline Yksin asuva mies alle $\mathbf{4 5} \mathbf{v}$ & 35 & 10 & 2 & 47 \\
\hline Yksin asuva nainen alle 45 v & 42 & 14 & 3 & 60 \\
\hline Yksin asuva mies yli 65 v & 31 & 9 & 2 & 42 \\
\hline Yksin asuva nainen yli 65 v & 34 & 11 & 3 & 49 \\
\hline Pari, 50+v työssä & 77 & 24 & 5 & 106 \\
\hline $\begin{array}{l}\text { Pari, nainen 50+v työssä, } \\
\text { mies 65+v eläkkeellä }\end{array}$ & 74 & 23 & 5 & 101 \\
\hline Pari, yli 65 v eläkkeellä & 65 & 20 & 5 & 91 \\
\hline YH-perhe, yksi leikki-ikäinen & 94 & 23 & 0 & 117 \\
\hline YH-perhe, kaksi teini-ikäistä & 142 & 46 & 8 & 196 \\
\hline Pikkulapsiperhe, kaksi lasta & 183 & 48 & 7 & 237 \\
\hline Lapsiperhe, kaksi lasta & 180 & 50 & 8 & 237 \\
\hline Teiniperhe, kaksi lasta & 181 & 50 & 10 & 241 \\
\hline Teiniperhe, kolme lasta & $\mathbf{2 3 0}$ & $\mathbf{6 6}$ & $\mathbf{0}$ & $\mathbf{2 9 6}$ \\
\hline
\end{tabular}

Lapsiperheiden kuvaukset: YH-perhe yksi leikki-ikäinen: äiti ja 3-v. tyttö; YH-perhe kaksi teini-ikäistä: äiti, 10-v. poika ja 13-v. tyttö; Pikkulapsiperhe: äiti, isä, poika 2 v ja tyttö 6 v; Lapsiperhe: äiti, isä, 4-v. poika ja 10-v. tyttö; Teiniperhe kaksi lasta: äiti, isä, teini-ikäistä: 14-v. tyttö ja 16-v. poika; Teiniperhe kolme lasta: äiti, isä, 10-v. poika, 15-v. poika ja 17-v. tyttö (ks. luku 3.)

Vuodesta 2015 vaatetuskustannukset ovat nousseet vain muutaman euron kuukaudessa pareillaja yksin asuvilla. Lapsiperheillä kustannusten kasvua on noin 10 euroa kuukaudessa, mikä johtuu lasten vaatteiden kallistumisesta. Aikuisten vaatteiden lievää hintojen nousua kompensoi käyttöiän pidentäminen. 
Vaatekulut ovat useimmilla viitebudjettitalouksilla suuremmat kuin lähinnä vastaavilla kotitalouksilla vuoden 2016 kulutustutkimuksessa. Yksin asuvien työikäisten miesten ja lapsiperheiden vaatekulut viitebudjetissa ovat vain hieman korkeammat kuin kulutustutkimuksen 25-44-vuotiaiden yksin asuvien miesten tai kahdenhuoltajan lapsiperheen keskimääräiset vaatetuskulut. Muista poiketen työikäisten naisten viitebudjetin vaatetuskulut ovat hieman alhaisemmat kuin 25-44-vuotiaiden naisten vaatetuskulut vuoden 2016 kulutustutkimuksessa.

Kulutustutkimuksen vaatetuskuluja verrattiin myös siten, että parhaiten ansaitseva viidennes kotitalouksista jätettiin pois ja tarkasteltiin vain neljän alimman tuloviidenneksen yhteiskeskiarvoja. Niihin verrattuna useimmissa talouksissa viitebudjetit ylittivät vielä selvemmin vastaavien talouksien keskikulutuksen. Kulutustutkimuksen aineistossa ei ollut mahdollista verrata aivan samankokoisiin lapsiperheisiin ${ }^{10}$ tai esimerkiksi perheisiin, joissa olisi ollut vain teini-ikäisiä. Aineiston pienuuden vuoksi erilaisista talouksista ei saanut luotettavia keskiarvoja.

Viitebudjetin runsautta keskimääräisiin vaatekuluihin verrattuna selittävät monet syyt. Budjetti on laskettu siistien, eri tilanteissa käyttökelpoisten vaatteiden mukaisesti. Kuluttajien välttämättöminä pitämät vaatteet on hinnoiteltu uutena hypermarketin keskihintaisena tuotteena keväällä 2018. Vaatteiden hinnat ovat kohonneet kulutustutkimuksen vuoden 2016 tilanteesta. Viitebudjettilaskelmissa ei ole käytetty halvimpia hintoja, koska keskihintaisten tuotteiden oletetaan kestävän käytössä paremmin. Käytännössä vaatteita ostetaan paljon alennusmyynneistä ja erityisesti lastenvaatteita hankitaan käytettynä, mutta näitä säästötapoja ei ole otettu laskelmassa huomioon. Viitebudjeteissa ei ole liioin huomioitu isommilta sisarilta perittyjä vaatteita, eikä mahdollisia vaatelahjoja, koska kaikilla vaatteiden periminen, saaminen tai edullisesti ostaminen ei ole mahdollista. Vaatteita saatetaan käyttää myös pidempään kuin viitebudjetissa on arvioitu, mikä myös alentaa kuukausikuluja. Näyttää myös siltä, että alemman tulotason taloudet tinkivät tai joutuvat tinkimään vaatetushankinnoistaan verrattuna paremmin ansaitseviin, koska heillä vaatekulut ovat vuoden 2016 kulutustutkimuksessa pienemmät (Omat laskelmat). On myös oletettavaa, että mitä enemmän vaatteita on käytössä, sitä pidempään ne keskimäärin kestävät, vaikka asiasta ei ole yksityiskohtaista tutkimusta.

Päiväkotiin tarvitaan vaihtovaatteita ja lisäksi esimerkiksi kurahousut ja kumisaappaat. Niitä ei ole vaatebudjetissa. Niiden huomioiminen kasvattaisi vaatebudjettia noin 3 euroa kuukaudessa päiväkotilasta kohden. Moni eroperheen lapsi asuu nykyisin vuoroviikoin jomman kumman vanhemman luona. Samat ulkovaatteet, kengät ja muut kalliimmat vaatteet ovat usein käytössä molemmissa

$10 \quad$ Kulutustutkimuksen kahden huoltajan lapsiperheessä oli keskimäärin 1,8 lasta ja yhden huoltajan talouksissa 1,3 lasta. 
talouksissa, mutta muista vaatteista eri talouksiin tarvitaan vaihtovaatteita. Tällöin molempien vanhempien luona vaatebudjetti on lähes yhtä suuri kuin viitebudjetissa. Vaatekulujen jakamisella ja vaihtovaatteita mukana kuljettamalla voidaan säästää.

\subsection{TIETOLIIKENNE}

Tietoliikenneryhmään sisältyvät sekä laitteet että tietoliikennemaksut. Tietoliikennelaitteet ja -järjestelmät kehittyvät koko ajan ja ovat tulleet entistä keskeisemmin osaksi arkeamme. Asioiden sujuva hoitaminen yhä useampien tahojen kanssa edellyttää nykyisin internetin käyttöä. Keskimäärin jo 88 prosenttia väestöstä käyttää internetiä ja 73 prosentti käyttää sitä useita kertoja päivässä. Enää noin 10 prosenttia väestöstä ei vielä koskaan ole käyttänyt internetiä. Heistä valtaosa on yli 74-vuotiaita. Internetiä käytetään moniin eri käyttötarkoituksiin, eniten sähköpostiviestintään (83 \%), pankkiasioiden hoitoon (82\%), verkkolehtien ja televisioyhtiöiden uutissivujen lukemiseen (79 \%) sekä tavaroita ja palveluita koskevaan tiedon etsintään (79 \%). (Tilastokeskus 2017b.)

Internetyhteys, tietokoneet ja älypuhelimet ovat nykyisin hyvin yleisiä. Lähes 90 prosentilla väestöstä on käytössään tietokone (kannettava $71 \%$, tabletti 51 $\%$, pöytäkone $36 \%$ ). Oma matkapuhelin on kaikilla alle 55 -vuotiailla ja useimmilla heistä se on älypuhelin, 55-64-vuotiaista älypuhelin on 80 prosentilla ja yli 65-vuotiaista sen omistaa noin 40 prosenttia. Internetyhteys on jo kaikilla talouksilla, joissa on enemmän kuin kaksi henkilöä tai nettotulot ovat yli 3100 euroa kuukaudessa. Myös useimmilla (yli 80 \%) pienituloisilla yhden ja kahden hengen talouksilla on kotoa nettiyhteys. Opiskelijat ja työssäkäyvät käyttävät internetiä pääasiassa matkapuhelimella, kun taas eläkeläisten eniten käyttämä laite on kannettava tietokone. (Tilastokeskus 2017b.)

Tietoliikennelaitteiden tarpeesta oltiin ryhmäkeskusteluissa yksimielisiä kaikilla paikkakunnilla. Henkilökohtaista matkapuhelinta pidettiin tarpeellisena aina kouluikäisestä lähtien ja kannettava tietokone katsottiin tarpeelliseksi kaikkiin talouksiin. Sanomalehden ja television välttämättömyydestä sen sijaan syntyi enemmän keskustelua. Tulostimen omistamista vain harva piti enää tarpeellisena, koska sähköinen asiointi yleistyy. Harvoin tarvittavat tulosteet voi tulostaa esimerkiksi kirjastossa, eivätkä kaikki kirjastot edes veloita muutaman sivun tulostuksesta. Erillistä viihde-elektroniikkaa ei liioin pidetty tarpeellisena, koska älypuhelimen tai tietokoneen kautta voi kuunnella musiikkia sekä katsella televisiota ja elokuvia. Ohessa muutama ote tietoliikennelaitteita koskevista keskusteluista: 
Internetyhteys ja tietokone on pakko, ihan välttämätön muuten ei hoiju [pankkija viranomaisasiat].

Nainen 71v, yksinasuva

... Ja tästä tietokoneesta. Mulle se oli enemmän välttämättömyys tai käytän enemmän.

Ja nykyään lapset kans tarvii vähänkin jos koulussa käy, nïn sitten on jo tietokone välttämätön. Ja ne puhelimet, melkein se ruukaa oleen se kappalemäärä, kuinka monta ihmistä on. Jo ala-asteelta eteenpäin, nün kai jo kaikille lapsille puhelimet on tärkeitä tohon yhteyden pitämiseen. ... Ja sit nää jo rupee vähän limittyyn, nää käyttötarkotukset. Kännykkää käytetään tietokoneen sijasta tosi paljon. Ja tietokone on korvannu TV:n lähestulkoon kokonaan meiän perheessä. Meillä on semmonen pikkutelkka, et se on ihan sama, kattooks sen tietokoneelta. Mutta ne on ne kolme asiaa, mitkä aateltiin välttämät-

tömäks. Muut on sitten, tulostimet ja tämmöset, niitä [tulosteita] nyt voi sitten käydä

kirjastossa tulostamassa. Ja ei tarvi tapella kuivuneitten musteitten kanssa kotona, jos sitä vain välillä käyttää.

Mies 42v, lapsiperhe

Keskustelujen perusteella tietokone tarvitaan yhä useammin henkilökohtaisena. Koululaisten vanhemmat toivat esiin, että nykyisin koulutehtävien tekeminen edellyttää käytännössä koululaisen omaa kannettavaa tietokonetta, läppäriä. Vain harva kunta tai koulu pystyy niitä kuitenkaan tarjoamaan, joten kustannukset lankeavat kodeille. Myös julkisessa keskustelussa on oltu huolissaan vähävaraisten lasten mahdollisuuksista hankkia opiskelussa tarvittavia laitteita ja opintomateriaaleja (Yle 2018 ${ }^{11}$ ). Kannettavaa tietokonetta tarvitaan joyläkoulussa moniin kotitehtäviin. Lukiossa ja ammattikoulussa sitä pidetään välttämättömänä. Ohessa on otteita tietoliikennekeskusteluista.

Esimerkiks lukiossa on pakko olla tietokone. Eikä mikään halpa tietokone, vaan ihan tosi sikahintainen, että sünä on kaikki ne speksit mitä pitää olla sit yokirjoituksiin.

Nainen 42v, lapsiperhe

On se ammattikoulussakin ihan sama. Ammattikoulu ja lukio, kummallakin pojalla on pakko olla koneet.

Nainen 49v, lapsiperhe

11 Yle selvitti: Näin erilaiset lähtökohdat lapset saavat koulutielle asuinpaikan perusteella - katso koulukoneesta, miten kuntasi menestyi. (päivitetty 16.5.2018) https://yle.fi/uutiset/3-10181489 
Kannettava-tietokone sanotaan, et on välttämätön jo yläasteikäsellä. Ne tekee ihan hirveen paljon sillä. Lukios se on ihan välttämätön. Et niillhän on kirjatja kaikki nykysin. Ja sit sanotaan aikuisilla ja vanhemmilla, ni pakko olla tietokoneet. Kaikkihan tapahtuu nykysin koneen kautta. Sä et pysty mitään enää tekeen ilman, jos et sä sit istu jossain kirjastossa iltaa tai jotain, mut kyl se ois aika mahdotonta. Ku aattelee, et Vilmat ja kaikki on tietokoneen kautta. No tietysti matkapuhelimen kautta sä pystyt hoitaan, jos sul on nettiyhteys sïnä.

Nainen $49 v$, lapsiperhe

Viitebudjeteissa koululaisten henkilökohtaisten kannettavien tietokoneiden tarve on otettu huomioon siten, että kaikilla yli 13-vuotiailla on omansa ja aikuisilla yksi yhteinen. Lisäksi kaikilla yli 7-vuotiailla on oma älypuhelin. Alakouluikäisten puhelimena on edullinen malli ja muilla keskihintainen.

Älypuhelimet ovat keskustelijoiden mielestä korvanneet esimerkiksi paperiset kalenterit, kameran ja osittain myös herätyskellon. Kouluikäisillä herätyskello tarvitaan. Monilla vanhemmilla on tapana ottaa lapsilta illalla puhelimet pois, jotta niitä ei nukkumaan menoajan jälkeen käytetä, kuten seuraavasta repliikistä ilmenee.

Mut ei lapsilla kyllä herätyskelloa korvaa sïtä syystä, ettei halua antaa niille sitä puhelinta mukaan sinne sängyn viereen, nïn herätyskello on pakko olla.

Nainen $42 v$, lapsiperhe

Television tarpeesta oli paljon keskustelua ja erityisesti nuoremmat keskustelijat totesivat katsovansa televisio-ohjelmat lähinnäläppäriltä. Vanhemmat eivät kuitenkaan halua seurata televisio-ohjelmia tietokoneelta. Kaikilla ei myöskään ole niin hyvää internetyhteyttä, että se riittäisi TV:n sujuvaan katseluun. TV:n tarvetta perusteltiin sillä, että läppäri ei mahdollista koko perheen yhteisiä TV:n katseluhetkiä:

Siis yleensä ne [lapset] kattoo kyllä läppärilläkin paljon, mutta sitten just mietin tuota, että läppäriltä ei voitais kattoo sillei, että koko perhe istuu sïnä. Että kyllä meillä tosi paljon katotaan nïnku sakilla. Ohjelmia.

Nainen 41v, lapsiperhe

Mulla ei oo televisiota. Silloin kun mä muutin omilleen, nïn oli tietokone oli se. Jos mä haluun kattoo jotain, nün mä katon tietokoneella sen. Mut mulla onkin pieni asunto 22 neliötä vaan nün on vähän hankala saaha mahtumaan yhtä sohovaa TV:n kans.

Mies 27v, yksinasuva 
Keskusteluissa oli erilaisia näkemyksiä television tarpeellisuudesta, mutta kotitehtävän perusteella lähes kaikki pitivät TV:tä edelleen tarpeellisena, joten se on säilytetty viitebudjetissa. Maksullisia TV-kanavia tai suoratoistopalveluja ei ole sisällytetty viitebudjettiin. Halutessaan niihin voi käyttää esimerkiksi kulttuuribudjettia, jos mieluummin haluaa katsoa elokuvia kotona elokuvateatterin sijaan. Paristoradiota pidettiin edelleen tarpeellisena muun muassa sähkökatkojen aikana viranomaistiedotteiden seuraamista varten. Sanomalehti puolestaanjää pois viitebudjetista, koska useimpien mielestä maksuttomat digilehdet korvaavat sen. Lisäksi lähes kaikilla paikkakunnilla on ilmaisjakelulehtiä, joissa on paikallisia uutisia.

Tietoliikennemaksut on hinnoiteltu edullisen 4G-liittymän perusteella. Puhelinmaksut ovat samat kaikilla puhelimen omistavilla. Internetliittymä puolestaan on talouden yhteinen ja sitä voi käyttää useammalla laitteella yhtä aikaa.

Tietoliikenne aiheuttaa viitebudjetissa merkittävän kuluerän, joka vaihtelee yksin asuvien 65 eurosta viiden henkilön talouden 157 euroon kuukaudessa (Taulukko 7).

Taulukko 7. Tietoliikennekustannukset viitebudjetissa kotitaloustyypeittäin vuonna 2018, e/kk.

\begin{tabular}{|c|c|c|c|}
\hline & $\begin{array}{l}\text { Tietoliikenne } \\
\text { laitteet, } € / \mathbf{k k}\end{array}$ & $\begin{array}{l}\text { Tietoliikenne- } \\
\text { maksut, } € / \text { kk }\end{array}$ & $\begin{array}{l}\text { Yhteensä, } \\
€ / \mathbf{k k}\end{array}$ \\
\hline Yksin asuva, alle $45 \mathrm{v}$ & 14 & 51 & 65 \\
\hline Yksin asuva, yli $65 \mathrm{v}$ & 14 & 51 & 65 \\
\hline Pari, yli 50 v työssä & 18 & 77 & 95 \\
\hline $\begin{array}{l}\text { Pari, nainen yli } 50 v \text { työssä, } \\
\text { mies yli } 65 \text { v eläkkeellä }\end{array}$ & 18 & 77 & 95 \\
\hline Pari, yli 65 v eläkkeellä & 18 & 77 & 95 \\
\hline YH-perhe, yksi leikki-ikäinen & 14 & 51 & 65 \\
\hline YH-perhe, kaksi teini-ikäistä & 27 & 77 & 104 \\
\hline Pikkulapsiperhe, kaksi lasta & 18 & 77 & 95 \\
\hline Lapsiperhe, kaksi lasta & 20 & 90 & 110 \\
\hline Teiniperhe, kaksi lasta & 39 & 103 & 142 \\
\hline Teiniperhe, kolme lasta & 41 & 116 & 157 \\
\hline
\end{tabular}

Lapsiperheiden kuvaukset ks. luku 3. 
Tietoliikenne kustannukset ovat kasvaneet vuoden 2015 viitebudjetista erityisesti teini-ikäisten perheissä (27-42 e/kk), koska lukioikäisestä lähtien koululaiset tarvitsevat oman kannettavan tietokoneen ja kaikilla yli 7-vuotiailla puhelin on nyt edullinen älypuhelin. Tietoliikennekulujen kasvua lieventää se, että sanomalehti ja tulostin jäivät budjetista pois, koska niitä ei enää pidetty välttämättöminä. Lisäksi tietoliikennemaksut ovat laskeneet aiemmasta hintapäivityksestä.

Kulutustutkimuksen ja viitebudjettien vertailu tietoliikennemaksujen ja -laitteiden osalta on sikäli hankalaa, että hyödykkeitä on jaoteltu niissä eri ryhmiin. Kulutustutkimuksen tietoliikenne sisältää postimaksut (viitebudjetissa ne ovat vapaa-ajanryhmässä) ja puhelinlaitteet, kun taas tietokoneet, televisiot ja radiot sisältyvät kulttuurin ja vapaa-ajan alaryhmään Audiovisuaaliset laitteet ja tietokoneet. Kun verrataan vuoden 2016 kulutustutkimuksen tietoliikenne- ja audiovisuaaliset laitteet ja tietokoneet -ryhmää yhteensä viitebudjetin tietoliikennekuluihin, niin viitebudjetissa ainoastaan iäkkäillä yksin asuvilla ja iäkkäillä pareilla tietoliikennekulut ovat keskikulutuksen luokkaa tai hieman korkeammat. Muilla talouksilla puolestaan viitebudjetit ovat selvästi vaatimattomammat kuin kulutustutkimuksen kulut. Useimpien viitebudjettitalouksien tietoliikennekulut jäävät selvästi alle keskikulutuksen myös, kun verrataan keskikulutukseen ilman suurituloisinta viidennestä.

\subsection{KODIN TAVARAT JA LAITTEET}

Kodintavarat ja laitteet on jaoteltu ryhmiin: kodinkoneet, kodin irtain (mm. huonekalut, matot, kodintekstiilit, astiat) sekä kertakäyttöiset kodin tarvikkeet. Monet kodin tavarat ja laitteet ovat kestokulutushyödykkeitä ja ne kestävät useita vuosia. Kestävien tuotteiden kuluina viitebudjettiin on laskettu vain kulumisen osuus siten, että hankintahinta on jaettu todennäköisellä käyttöiällä. Kestävien tuotteiden käyttöikiä on viitebudjetin päivityksen yhteydessä tarkistettu. Kestävistä kodin tavaroista ja latteista suuri osa on sellaisia, ettei kotitalouden koolla ole merkitystä niiden tarpeeseen ja määrään. Sen sijaan esimerkiksi kertakäyttöisten paperitavaroiden ja pesuaineiden tarve kasvaa kotitalouden henkilömäärän ja asunnon koon kasvaessa. Markkinoilla on tarjolla tähän tuoteryhmään hyvin runsaasti erilaisia tuotteita. Viitebudjettiin sisältyy niistä vain pieni osa eli vain netuotteet, jotka kuluttajaryhmät keskusteluissa ja kotitehtävässä katsoivat välttämättömiksi. 


\title{
Kodinkoneet
}

Viitebudjettitalouksien oletetaan hallitsevan ruoanvalmistuksen ja kodinhoidon perusasiat sekä olevan pitkälti omatoimisia. Monia kodinkoneita ja apuvälineitä kuuluu tämän päivän kotitalouksiin, koska ne helpottavat tai sujuvoittavat toimintoja merkittävästi. Ohessa esimerkki ryhmäkeskustelijoiden kodinkoneisiin liittyvistä pohdinnoista ja perusteluista toisen keskustelukierroksen paritehtävän jälkeen:

\begin{abstract}
... Niin, me puhuttiin kodinkoneista ja irtaimistosta, niinkun huonekaluista ja muusta vähän isommasta tarpeesta. Ja ehkä vois summata, että nää kaikkein tarpeellisimmat asiat oli mun mielestä neljään ryhmään, elikkä ruuanlaittoon, vaatehuoltoon. Sitten, tai oikeestaan kolmeen ryhmään, jos yhdistää sïvouksen ja yleensä sïsteyden, on nïnkun inhimillistä elää ja pystyy tulemaan sit ihmisten ilmoillekin. Ja tota, jos me ihan kaikkein välttämättömimpiä listattiin, nïn ne oli liesi tai sit vaihtoehtoisesti mikroaaltouuni, jolla voi tehä sitä ruokaa kotona, ettei oo sitten ihan nïnkun noutoruuan tai ravintoloiden armoilla. Ja sitten samanlailla ruuan säilytyksessä, niin jääkaappi ja pakastin tai sit vaihtoehtosesti jenkkikaappi, jossa olis joku pakastelokero. Ne olis tärkeimmät, et pystyy vähän pidemmälle ajalle rytmittämään sitä ruuanvalmistusta ja olis sit jonkinlaista varantoo siellä kotonakin. Ja sit puhuttïn siitä, että miten se vaatehuolto. Nïn, senhän voi tietysti tehä periaatteessa nyrkkipyykilläkin ja vaikka rikkalapion ja luutun kanssa. Mutta tota, käytännössä varmaan pyykkikone ja imuri on sellaset laitteet, mitä varsinkin nyt lapsiperheessä on käytännös välttämättömiä.
\end{abstract}

Mies 29v, yksinasuva

Liesi ja jääkaappi-pakastin sisältyvät viitebudjetin hyödykekoriin, mutta koska vuokranantaja hankkii ne vuokra-asuntoon perusvarusteina, niitä ei ole mukana viitebudjetin kuluissa ${ }^{12}$. Myös pyykinpesukonetta pidettiin tarpeellisena kaikkiin talouksiin. Mikäli taloyhtiössä on kiinteistöpesula (pesutupa), niin sitä voisi hyödyntää ja säästään pesukonehankinnassa. Keskustelijoiden mielestä sen käyttöön ei voi kuitenkaan velvoittaa, koska vain harvalla on siihen mahdollisuus, eikä yhteisten tilojen ja laitteiden käyttö aina ole sujuvaa. Erillistä pakastinta ei enää pidetty missään talouksissa enää välttämättömänä, joten se jäi pois.

Kaikki eivät aluksi pitäneet silitysrautaa tarpeellisena, mutta keskusteluissa yhteisymmärrys sen tarpeesta syntyi. Todettiin, että monet juhlavaatteet edellyttävät silitystä, jotta olisivat siistejä. Silitysraudan lisäksi kaikissa kotitalouksissa tarpeellisina pidettiin myös pölynimuria, mikroaaltouunia, kahvinkeitintä, vedenkeitintä, sauvasekoitinta ja sähkövatkainta. Lista pienkoneista on kompromissi, sillä osa piti tarpeellisena esimerkiksi smoothie-sekoitinta, mutta ei esimerkiksi kahvinkeitintä tai sähkövatkainta. Astianpesukonetta monet pitivät kätevänä, mutta keskustelujen ja kotitehtävän perusteella päädyttiin siihen, että se on tarpeellinen pareilla ja lapsiperheissä. Yksin asuvien asuntoihin se ei aina edes mahdu ja pienissä talouksissa tavanomainen tiskimäärä on vähäinen.

12 Vuoden 2013 budjettiin niiden kuluminen (3,50 e/kk) oli laskettu mukaan. 
Kodinkoneiden lista pysyi pitkälti aiemman viitebudjetin kaltaisena. Aiemmin yhden hengen talouksissa oli vähän vaatimattomampi varustelu, mutta nyt kaikille on budjetoitu samat kodinkoneet lukuun ottamatta astianpesukonetta. Kodinkoneiden kuukausikustannukset yksin asuvilla ovat noin seitsemän euroa kuukaudessa ja muilla kotitalouksilla noin 11 euroa. Yksityiskohtaiset tiedot viitebudjettien sisältämistä kodinkoneista ja niiden todennäköisestä käyttöiästä ovat liitteessä 1. Kustannukset ovat pysyneet lähes samoina kuin aiemmin.

Viitebudjettien välttämättömien kodinkoneiden kulut ovat useimmilla viitebudjettitalouksilla noin puolet vastaavien kotitalouksien todellisesta kulutuksesta kulutustutkimuksessa ja runsas puolet neljään alimpaan tuloviidenneksen verrattuna. Yksin asuvilla iäkkäillä ja iäkkäillä pareilla erot ovat pienimmät.

\section{Huonekalut ja muu kodin irtain}

Kodin irtaimistoon kuuluu monia erilaisia tavaroita: huonekalut, tekstiilit, matot sekä astiat ja välineet, joita tarvitaan ruoanvalmistuksessa-, tarjoilussa ja ruokaillessa (Liite 1). Niiden määriin vaikuttaa niin perheen kuin myös asunnon koko. Viitebudjettiin sisältyvien tavaroiden lista pysyi pitkälti samanlaisena kuin aiemmin. Asiantuntijaryhmän ehdotuksesta huonekalujenjajoidenkin muiden kestävien tavaroiden käyttöikiä pidennettiin. Ohessa ote paritehtävän liittyvästäkeskustelusta, jossa pohdittiin kodintekstiilien ja huonekalujen tarvetta:

Mies 1: Ja tota, sitten tietysti vuodevaatteet ja pyyhkeet liittyy sïhen yleiseen hygieniaan ja sïsteyteen. Ja sit keskusteltiin sellasesta, että onko verhot esimerkiks tarpeellisia. Sulla ei ollu.

Mies 29v, yksinasuva

Mies 2: Mulla ei ollu. Mä oon jotenkin tottunu, mä oon aina asunu vähän korkeemmalla, ettei oo koskaan ketään sïn ikkunan ulkopuolella tuijottamassa sisään. Mutta tavallaan, että no onhan täällä kesällä melkein 24/7 valosaa.

Mies $48 v$, pariskunta

Mies 1: Ja toinen, mikä nïnkun, matot taas vastaavasti voi olla talvella yllättävän kivat, rïppuen siitä, et miten asuu. Mutta eihän nekään nyt ihan absoluuttisen välttämättömiä ole. Mut kyl me nyt laitettiin ne tähän listaan sitten. Ja yks, mikä nyt ehkä pitää tässä nostaa erikseen esïn, on vielä se valaistus, kun on tosiaan nää pimeet talvet, niin kyllä nyt jonkinlainen valo pitää löytyä aina asunnosta. Ja sit, jos sitä huonekalupuolta miettii, nïn ehkä se kaikkein keskeisin tän sängyn jälkeen, jossa voi nukkua, niin on sit se, että missä voi tehdä jotain nï̈kun, et jonkinlainen ruokailuryhmä tai pöytä ja työtuoli, sen asujamäärän mukaan. Nää olis ehkä semmoset, mitä ilman olis tosi ikävää olla, ja ei olis sitten ehkä täyspainoisesti työelämän käytettävissä ja lomakkeita täyttelemässä.

Mies 29v, yksinasuva 
Huonekaluista viitebudjetissa ovat mm. sängyt, tuolit, ruokapöytä tuoleineen, sohva ja kouluikäisille työpöytäja työtuoli. Lisäksi tässä ryhmässä on mattoja, liinavaatteita ja muita tavanomaisia kodintekstiilejä melko suppea määrä,joka on suhteutettu esimerkkitalouden ja sen asunnon kokoon. Sivuverhot on varattu kaikkiin ikkunoihinja makuuhuoneisiin lisäksi pimentävä rullaverho. Tauluja, koriste-esineitä tai-kasveja ei budjettiin sisälly. Näitä kodin viihtyisyyttä lisääviä tuotteita on ajateltu saatavan lahjoina. Huonekalujen, kodintekstiilien, astioiden ja ruoanvalmistusvälineiden yhteen lasketut kustannukset vaihtelivat viitebudjettitalouksissa yksin asuvien alle 45-vuotiaiden 27 eurosta kuukaudessa viiden hengentalouden 62 euroon (Taulukko 8). Yksityiskohtainen tuotteiden lista ja niiden käyttöiät esitetään liitteessä 1.

Taulukko 8. Huonekalujen, kodintekstiilien, astioiden ja ruoanvalmistusvälineiden kustannukset viitebudjetissa kotitaloustyypeittäin vuonna 2018, e/kk.

\begin{tabular}{|c|c|c|c|c|}
\hline & $\begin{array}{c}\text { Huonekalut, } \\
€ / \mathbf{k k}\end{array}$ & $\begin{array}{l}\text { Kodintekstiilit ja } \\
\text { matot, } € / \mathbf{k k}\end{array}$ & $\begin{array}{c}\text { Astiat ja ruoan- } \\
\text { valmistusvälineet, } \\
€ / \mathbf{k k}\end{array}$ & $\begin{array}{l}\text { Yhteensä, } \\
€ / \mathbf{k k}\end{array}$ \\
\hline Yksin asuva, alle $45 \mathrm{v}$ & 11 & 10 & 5 & 27 \\
\hline Yksin asuva, yli 65 v & 11 & 10 & 5 & 27 \\
\hline Parit, työssä/eläkkeellä & 13 & 15 & 6 & 34 \\
\hline YH-perhe, yksi leikki-ikäinen & 13 & 14 & 7 & 34 \\
\hline YH-perhe, kaksi teini-ikäistä & 20 & 19 & 7 & 46 \\
\hline Pikkulapsiperhe, kaksi lasta & 20 & 23 & 8 & 51 \\
\hline Lapsiperhe, kaksi lasta & 21 & 24 & 8 & 53 \\
\hline Teiniperhe, kaksi lasta & 22 & 24 & 8 & 54 \\
\hline Teiniperhe, kolme lasta & 26 & 27 & 8 & 62 \\
\hline
\end{tabular}

Lapsiperheiden kuvaukset: YH-perhe yksi leikki-ikäinen: äiti ja 3-v. tyttö; YH-perhe kaksi teini-ikäistä: äiti, 10-v. poika ja 13-v. tyttö; Pikkulapsiperhe: äiti, isä, poika 2 v ja tyttö 6 v; Lapsiperhe: äiti, isä, 4-v. poika ja 10-v. tyttö; Teiniperhe kaksi lasta: äiti, isä, teini-ikäistä: 14-v. tyttö ja 16-v. poika; Teiniperhe kolme lasta: äiti, isä, 10-v. poika, 15-v. poika ja 17-v. tyttö (ks. luku 3)

Niin huonekalujen kuin myös kodintekstiilienja mattojen sekäastioidenja ruoanvalmistusvälineiden kuukausikustannukset ovat pysyneet lähes samana kuin vuonna 2015. Niiden kuukausikustannukset ovat kohonneet useimmilla talouksilla vain muutaman euron, mikä lähinnä johtuu hintojen noususta. 
Vertailussa kulutustutkimuksen kaikkiin vastaaviin talouksiin viitebudjettien rajallisuus tulee esiin: esimerkiksi kahden huoltajan lapsiperheen huonekalujen, kodintekstiilien ja mattojen sekä astioiden ja ruoanvalmistusvälineiden budjetti kattaa alle 40 prosenttia. Iäkkäillä uusien tuotteiden hankintoja on harvemmin ja ilmeisesti sen vuoksi viitebudjetti kattaa lähes 90 prosenttia kulutustutkimuksen mukaisesta iäkkäiden keskikulutuksesta. Neljään alimpaan tuloviidennekseen verrattuna viitebudjettitalouksien kuukausikustannusten erot hieman kaventuvat, mutta ovat iäkkäitä lukuun ottamatta useimmilla talouksilla edelleen huomattavan suuret. Suuri ero johtuu siitä, että viitebudjetissa on katsottu välttämättömäksi vain erittäin rajattu määrä tuotteita ja iäkkäillä uusien tuotteiden ostoja on harvemmin kuin nuoremmilla.

\section{Kodin tarvikkeet}

Kodin tarvikkeisiin kuuluvat erilaiset siivouksen ja vaatehuollon välineet sekä perustyökalut ja muita arjen toimintoja helpottavia kodin tarvikkeita. Niistä useimmat kestävät vuosia. Kertakäyttöisiä kodin tarvikkeita puolestaan ovat esimerkiksi pyykinpesu-ja siivousaineet sekä erilaiset pakkaus-ja paperitarvikkeet,joiden vuosi-tai kuukausikulutuksen arviointia kuluttajat pitivät vaikeana. Kodin tarvikkeiden lista pysyi lähes ennallaan ja tarvittavat määrät pidettiin niin ikään samana kuin aiemmin (Liite 1; vrt. Lehtinen \& Aalto 2014). Isoissa kotitalouksissa kodin tarvikkeita kuluu enemmän kuin pienissä. Niiden kuukausikustannukset vaihtelivat 10-25 euroa kuukaudessa (Taulukko 9). Kuukausikustannukset ovat pysyneet samalla tasolla kuin aiemmassa viitebudjetissa ${ }^{13}$. Joidenkin pesuaineiden hinnat ovat jopa alhaisemmat kuin aiemmin.

13 Aiemmassa viitebudjetissa vuodelle 2013 (Lehtinen \& Aalto 2014) oli laskentakaavavirheen vuoksi liian suuret pesu- ja siivousainekulut. Virhe korjattiin yhteenvetotaulukkoon 2015 indeksikorotuksen yhteydessä. 
Taulukko 9. Kodin tarvikkeiden kustannukset viitebudjetissa kotitaloustyypeittäin vuonna 2018, e/kk.

\begin{tabular}{|c|c|c|c|c|c|}
\hline & $\begin{array}{c}\text { Siivouksen ja } \\
\text { vaatehuollon } \\
\text { välineet, } \\
€ / \mathbf{k k}\end{array}$ & $\begin{array}{c}\text { Muut kodin } \\
\text { tarvikkeet ja } \\
\text { työkalut, } \\
€ / \mathbf{k k}\end{array}$ & $\begin{array}{c}\text { Pesu- ja } \\
\text { siivous- } \\
\text { aineet, } € \\
\text { /kk }\end{array}$ & $\begin{array}{c}\text { Paperi- ja } \\
\text { pakkaus- } \\
\text { tarvikkeet, } \\
\text { yms., €/kk }\end{array}$ & $\begin{array}{c}\text { Yhteensä, } \\
€ / \mathbf{k k}\end{array}$ \\
\hline Yksin asuva, alle $45 \mathrm{v}$ & 2 & 1 & 1 & 6 & 10 \\
\hline Yksin asuva, yli $65 \mathrm{v}$ & 2 & 1 & 1 & 7 & 11 \\
\hline Parit, työssä/eläkkeellä & 2 & 1 & 3 & 8 & 14 \\
\hline YH-perhe, yksi leikki-ikäinen & 2 & 1 & 3 & 11 & 17 \\
\hline YH-perhe, kaksi teini-ikäistä & 2 & 1 & 4 & 11 & 18 \\
\hline Pikkulapsiperhe, kaksi lasta & 2 & 1 & 5 & 12 & 20 \\
\hline Lapsiperhe, kaksi lasta & 2 & 1 & 5 & 13 & 21 \\
\hline Teiniperhe, kaksi lasta & 3 & 1 & 5 & 14 & 22 \\
\hline Teiniperhe, kolme lasta & 3 & 1 & 5 & 16 & 25 \\
\hline
\end{tabular}

Lapsiperheiden kuvaukset ks. luku 3.

Kodin tarvikkeiden viitebudjetti kattaa noin 20-60 prosenttia kulutustutkimuksen kodintarvikemenoista. Kun budjetteja verrataan vastaavien kotitalouksien neljän alimman tuloviidenneksen keskikulutukseen, niin kattavuus hieman paranee. Enimmillään kattavuus on alle 45-vuotiailla yksin asuvilla ja yksinhuoltajilla, joiden vastaavien tuotteiden kulutuksesta se kattaa hieman yli 60 prosenttia.

\subsection{TERVEYS, HYGIENIA JA KAUNEUDENHOITO}

Julkisuudessa on esiintynyt huolta siitä, että varojen puutteessa tingitään välttämättömistä lääkehankinnoista ${ }^{14}$. Kotitalouden jäsenet on viitebudjetissa määritelty perusterveiksi (ei allergioita tai muita kroonisia sairauksia). Oletuksena on lisäksi, että kotitalouden jäsenet huolehtivat hygieniastaan ja kunnostaan. Myös kuluttajat korostivat keskusteluissa ihmisten omaa vastuuta huolehtia omasta terveydestään:

14 Katri Aaltonen: https://yle.fi/uutiset/3-9768086 
Must tähän [terveyteen] kuuluu myös liikunta, että semmoinen itsehoidollinen puoli, et liikunta on tärkee kanssa, jos vaan sisua rïttää.

Nainen 65, pariskunta

Mä kans ehkä yhdistäisin tota ruoka, terveys, harrastukset, vapaa-aika sen tyyppistä, että sitä jollain kokonaisuudella voi kattoa. Koska periaatteessa silloin terveyden kohalla pärjää pitkälti julkisella terveydenhuollolla, missä laskee sitten vuodessa muutaman ihan peruskäynnin, jos sitäkään.

Mies 29v, yksinasuva

Terveydenhoidon budjetissa noudatettiin pääosin samoja periaatteita kuin vuosien 2010 ja 2013 viitebudjeteissa. Edellisissä viitebudjetissa ei varattu rahaa reseptilääkkeisiin. Mihinkään tiettyihin kroonisiin tai pitkäaikaisiin sairauksiin viitebudjetissa ei ole nytkään varauduttu ${ }^{15}$. Niiden yksilöiminen ja määrittäminen todettiin hankalaksi.

Joillakin ihmisillä se [lääkekatto] päättyy tammikuun alussa, kun ne ostaa ne lääkkeet, se jota ne tarvii tammikuussa tai ihan ensimmäisellä viikolla. Et useimmil ihmisillä kuitenkin on sit matkaa sinne kattoon. Mutta nïn kyl ihmiset on nün kauheen erilaisis tilanteissa lääkkeitten suhteen, et sitä on ihan mahdoton sanoo mitenkään yleisesti.

Nainen 67v, yksinasuva

Nyt keskustelijat pitivät tärkeänä, että vähintään satunnaisiin reseptilääketarpeisiin varaudutaan, kuten alla oleva sitaatti osoittaa.

No mun mielestä pitää pystyy varautuun sellaisiin yllättäviin sairastumisïn, jos tarvii jotain, mitä nyt antibioottia tai tollaisia, mitä tarvii aina silloin tällöin. Että se eläminen ei oo sellaista, että tommoisïn silloin tällöin esïntyviin sairauksiinkaan ei oo varaa hankkia lääkitystä tai käydä terveysasemalla.

Nainen 25v, yksinasuva

Tässä budjetissa reseptilääkkeisiin on varauduttu. Kelan Tieto- ja tilastovastuun ryhmässä laskettiin kuluttajien maksamat lääkekulut vuoden 2016 tilastosta koko väestön reseptilääkkeiden mediaaniomavastuun perusteella. Kustannukset määriteltiin ikäryhmittäin erikseen miehilleja naisille. Reseptilääkekustannukset vaihtelivat 14-206 euroa henkilöä kohden vuodessa. Alle 24-vuotiailla mediaanijäi nollaksi.

15 Suurella osalla väestöä ei ole tarvetta jatkuvaan lääkitykseen. Kun viitebudjetteja hyödynnetään yksilöllisesti, on syytä lisätä kunkin kroonisen sairauden hoitoon tarvittavien lääkkeiden yksilölle aiheutuvien todellisten kustannusten mukaisesti. Erilaisten sairauksien hoitoon tarvittavien lääkekustannusten määrittäminen yleisesti sovellettavaan viitebudjettiin ei ole mahdollista kustannusten suuren yksilöllisen vaihtelun vuoksi. Lääkekustannuksille on vuosittainen maksukatto (2018: 605 euroa). 
Nuorten ikäryhmästä vain alle puolet oli tarvinnut reseptilääkkeitä. Lapsille kuitenkin kohdennettiin viitebudjetissa reseptilääkekuluja 5 euroa vuodessa. Kaikissa lapsiperheissä vanhempien viiteryhmänä on 25-44-vuotiaat.

Ehkäisyyn oli aiemmassa budjetissa varattu kondomeja täysi-ikäisille miehille ja naisille. Keskustelijat pitivät kuitenkin edellistä parempana vaihtoehtona varata 18-45-vuotiaille naisille ehkäisypillerit. Niiden kulut määritettiin tavanomaisimpien ehkäisyvalmisteiden kuukausikulujen perusteella (9 e/kk, 108 e/v). Yksin asuville miehille varattiin edelleen kondomeja. Teini-ikäisille ei varattu ehkäisyvälineitä. Osa kunnista kustantaa teineille ilmaisen ehkäisyn ja monissa nuorten tilaisuuksissa jaetaan ilmaisia kondomeja.

Julkisen terveydenhuollon maksut vaihtelevat kunnittain. Viitebudjetissa lääkärikäynnit on hinnoiteltu sosiaali- ja terveysministeriön määrittelemän enimmäiskertamaksun mukaan terveyskeskuslääkärille. Kertamaksu (20,60 e) voidaan periä yhdessä terveyskeskuksessa korkeintaan kolme kertaa vuodessa (STM 2018). Kaikille alle 65-vuotiaille on laskettu budjettiin yksi terveyskeskuslääkärinkäynti vuodessa ja sitä vanhemmille kolme. Niin ikään hammaslääkärikäynti on julkisen terveydenhuollon maksujen mukainen. Hammaslääkärilläkäynti on hinnoiteltu aikuisille joka toiselle vuodelle ja se sisältää perustarkastuksen lisäksi plakinpoiston ja yhden pinnan paikkauksen. Lapset hyödyntävät maksutonta hammashoitoa. Lisäksi aikuisille on budjetissa varattu yksi erikoislääkärikäynti vuodessa.

Terveydenhoidosta puhuttaessa lapsiperheiden edustajat korostivat tapaturmavakuutusten tarvetta lapsille. Tyypillinen tapaturmavakuutus korvaa lääkärinpalkkioita, hoito- ja tutkimuskuluja, lääkkeitä ja sairaalamaksuja, usein ilman omavastuuta. Se saattaa sisältää myös kuolemantapauskorvauksen, urheilussa sattuneiden vammojen hoitoja sekä haittakorvauksen, jonka suuruus määritellään sopimuskohtaisesti. Lapsille on tarjolla erillisiä lasten tapaturmavakuutuksia. (Summarum media 2012.) Lasten vanhemmat toivat keskusteluissa esiin myös sen, että urheiluseurat edellyttävät juoniorijäseniltään tapaturmavakuutusta.

Viitebudjettiin tapaturmavakuutus otettiin keskustelujen perusteella vain lapsille. Lasten tapaturmavakuutuksen hintaan vaikuttaa lapsen ikä (alle 10v 2,50 e/ kk, 10-12 v 3 e/kk ja 13-17 v 3,40 e/kk). ${ }^{16}$

Terveydenhoidon kokonaiskustannukset on koottu Taulukkoon 10 ja sisällön yksityiskohdat on esitetty liitteessä 1 . Terveydenhoidon kustannukset vaihtelivat yksin asuvien nuorten 23 eurosta eläkeläisparin 83 euroon kuukaudessa.

16 Laskuri lasten tapaturmavakuutuksista https://www.henkivakuutuskuntoon.fi/lapsenturva?ref=WgRC2Ck AABIAomHs WkssFisAAI-r4sEh (luettu12.1.2018) 
Taulukko 10. Terveyden, hygienian ja kauneudenhoidon kustannukset viitebudjetissa kotitaloustyypeittäin vuonna 2018, e/kk.

\begin{tabular}{|c|c|c|c|c|c|}
\hline & $\begin{array}{l}\text { Terveyden- } \\
\text { hoito, } € / \mathbf{k k}\end{array}$ & $\begin{array}{c}\text { Hygienia- } \\
\text { tarvikkeet, } \\
€ / \mathbf{k k}\end{array}$ & $\begin{array}{c}\text { Hygienia- } \\
\text { tuotteet ja } \\
\text { kosmetiikka, } \\
€ / \mathbf{k k}\end{array}$ & $\begin{array}{c}\text { Hiusten } \\
\text { hoito- } \\
\text { tarvikkeet } \\
\text { ja leikkaus, } \\
€ / \text { kk }\end{array}$ & $\begin{array}{l}\text { Yhteensä, } \\
€ / \mathbf{k k}\end{array}$ \\
\hline Yksin asuva mies alle $45 \mathrm{v}$ & 23 & 3 & 7 & 17 & 50 \\
\hline Yksin asuva nainen alle $45 \mathrm{v}$ & 32 & 5 & 15 & 14 & 66 \\
\hline Yksin asuva mies yli $65 \mathrm{v}$ & 44 & 4 & 7 & 13 & 68 \\
\hline Yksin asuva nainen yli $65 \mathrm{v}$ & 43 & 5 & 12 & 14 & 74 \\
\hline Pari, yli 50 v työssä & 53 & 6 & 19 & 30 & 107 \\
\hline $\begin{array}{l}\text { Pari, nainen yli } 50 v \text { työssä, } \\
\text { mies yli } 65 \text { v eläkkeellä }\end{array}$ & 68 & 7 & 19 & 28 & 120 \\
\hline Pari, yli 65 v eläkkeellä & 83 & 7 & 19 & 27 & 135 \\
\hline YH-perhe, yksi leikki-ikäinen & 35 & 6 & 17 & 20 & 77 \\
\hline YH-perhe, kaksi teini-ikäistä & 43 & 10 & 23 & 35 & 111 \\
\hline Pikkulapsiperhe, kaksi lasta & 62 & 9 & 24 & 39 & 135 \\
\hline Lapsiperhe, kaksi lasta & 62 & 9 & 24 & 40 & 135 \\
\hline Teiniperhe, kaksi lasta & 70 & 15 & 30 & 52 & 166 \\
\hline Teiniperhe, kolme lasta & 74 & 15 & 33 & 58 & 180 \\
\hline
\end{tabular}

Lapsiperheiden kuvaukset ks. luku 3.

Henkilökohtaisessa hygieniassa tarpeellisiksi tai välttämättömiksi hyödykkeiksi katsottiin tavanomaiset pesuaineet, deodorantti, perus-, käsi- ja auringonsuojavoide sekä hiustenhoitoon shampoo, hoitoaine, hiusten muotoilutuote ja hiusten leikkaukset (aikuisilla noin joka toinen kuukausi, lapsilla harvemmin; Liite 1).

Terveydellä, hyvällä hygienialla ja ulkonäöstään huolehtimisella katsottiin olevan monia merkityksiä ja niiden katsotaan liittyvän tiiviisti yhteen, kuten seuraavista sitaateista käy ilmi.

Nii, tää on ehkä semmonen asia, et se on äkkiä sit nïn kun terveyden edesauttamista ja ylläpitoo myöskin, että hampaat harjataan ja muuta tämmöstä. On ne tarpeelliset lääkkeet kaapissa ja pysyy puhtaana, ja muuta vastaavaa.

Nainen 25v, pariskunta 
Mulla on nyt sillei, että mä oon vïmeks käyny [kampaajalla] ennen vïme juhannusta [yli gkk sitten], koska mulla ei oo ollu yksinkertasesti varaa sïhen. Mut sïs kyllä oon miettiny monesti, et mistä nyt luopuu. Nïn, ens kuussa oon sit menossa kampaajalle. Mut se tuntuu, että se on naiselle varsinkin jotenkin niï tärkee, et se vaikuttaa itsetuntoon ja moneen asiaan, että ei se kerran tai kaks kertaa vuoteen ehkä oo ihan nïn kun tarpeeks. Tai mun mielestä pitäis olla oikeus käydä useammin.

Nainen 26v, pariskunta

Aiemmin viitebudjettiin sisällytettiin useita erilaisia ihonhoito- ja värikosmetiikkatuotteita, joiden hankinnasta sisällytettiin budjettiin puolet. Tässä budjetissa tuotevalikoimaa supistettiin merkittävästi ja kaikkien mukana olevien esimerkkituotteiden kustannukset otettiin mukaan. Useimpien naisten ja monien miesten mielestä kohtuullinen määräihonhoito-ja värikosmetiikkatuotteita on tarpeen ihon terveyden ja siistin ulkonäön vuoksi.

Jos mä meen työhaastatteluun, niin kyl mun on meikattava. En mä voi mennä sinne sillein, et naama punottaa sieltä täältä, tai muuta, koska mä haluan antaa hyvän kuvan. Ja hyvää kuvaa ei nykypäivänä anna, jos sä oot vähän siten sun täten. Et jos sä haiset hielle tai hiukset on likaset tai sä oot täysin laittamaton ja näin.

Nainen 27v, yksinasuva

Kyl mä miehillekin laittaisin jonkinlaista ihonhoitotuotetta. Ainakin mulla menee tosi huonoon kuntoon talvella se iho.

Mies $48 v$, pariskunta

Hygienia-, hiustenhoitoyms. kustannukset eri kotitalouksille on koottu Taulukkoon 10 yhdessä terveyskustannusten kanssa. Hygienian, hiustenhoidon ja kauneudenhoidon yhteen lasketut kustannukset vaihtelivat yksin asuvien yli 65-vuotiaiden miesten 26 eurosta kolmen teini-ikäisen perheen 106 euroon kuukaudessa. Yksityiskohtainen luettelo viitebudjettiin sisältyvistä hygieniatuotteista on liitteessä 1.

Henkilökohtaisen hygienian kustannukset ovat useimmilla viitebudjettitalouksilla muutaman euroa pienemmät kuin aiemmin, mikä johtuu lähinnä laskentatavan muutoksesta. Laskennassa ei ole kosmetiikan tai hiustenhoidon laajoja tuotepaketteja kuten aiemmin, jolloin niiden yhteissumma puolitettiin. Nyt tuotevalikoimaa on supistettu ja kaikki hyödykekorin tuotteet tästä ryhmästä ovat budjetissa mukana. Esimerkiksi hiusväri on jätetty kokonaan pois, koska keskustelijat eivät pitäneet sitä välttämättömänä. 
Terveydenhoidon kustannukset puolestaan ovat kasvaneet. Ehkäisyvälineet on siirretty hygieniatuotteista terveydenhoitoon. Ryhmään on siirretty myös lasten tapaturmavakuutukset. Eniten terveydenhoidon budjetti on kasvanut reseptilääkkeiden ja ehkäisypillereiden lisäämisen vuoksi. Reseptilääkekulujen huomioiminen on kasvattanut erityisesti yli 65-vuotiaiden terveydenhoitokuluja. Kaikilla kotitalouksilla henkilökohtaisen hygienian ja terveydenhoidon yhteenlasketut menot ovat viitebudjeteissa kasvaneet.

Terveydenhoitomenot ovat viitebudjetissa edelleen vaatimattomat. Ne kattavat noin puolet kaikkien vastaavien talouksien keskimääräisistä terveydenhoitokuluista verrattuna kulutustutkimukseen. Ilman suurituloisinta tuloviidennestä terveydenhoitomenot ovat jokaisella kotitaloustyypillä hieman alhaisemmat kuin kaikilla kotitalouksilla keskimäärin, joten niistä viitebudjetit kattavat useimmilla kotitaloustyypeillä yli 60 prosenttia.

Puhtauden- ja kauneudenhoidon yhteen lasketut kulut puolestaan ovat lähes samansuuruiset kuin vuoden 2016 kulutustutkimuksessa, eivätkä keskikulut juuri muutu, jos ylimmän tuloviidenneksen rajaa pois. Keskikulutukset ylittyvät teiniikäisten perheissä, joissa tarvitaan enemmän ja useammanlaisia hygieniatuotteita kuin pikkulapsiperheissä (deodorantit, kuukautissuojat ym.).

\subsection{HARRASTUKSET JA VAPAA-AIKA}

Ryhmäkeskustelijat olivat yksimielisiä siitä, että jokaisella pitäisi olla mahdollisuus harrastaa jotain muutakin kuin kävelyä. Harrastuksia pidettiin tärkeänä osana terveyden ylläpitämistä ja itsestä huolehtimista, niin fyysisesti kuin henkisestikin. Erityisesti korostettiin lasten harrastusten merkitystä ja niihin liittyviä sosiaalisia verkostoja. Sekä keskustelujen että tutkimusten mukaan lapset aloittavat säännöllisen harrastuksen pääsääntöisesti 6-7-vuotiaana (Kokko \& Mehtälä 2016), joten harrastusbudjetti on kohdennettu kouluikäisille lapsille ja sitä vanhemmille. Oheisissa keskustelusitaateissa tulevat esiin harrastusten moninaiset merkitykset.

... Jos lapsella ei oo mitään harrastuksia, nïn voiks siit kasvaa sosiaalinen yhteiskunnan jäsen?

Nainen 27v, yksinasuva 
Joo on se [harrastus] tärkee kun on kaikkee koulukiusaamista ja muuta, et sit tavallaan ne sun kaverit on siellä koulussa. Nïn jos sä oot vaikka koulukiusattu, niin sitten sulla voi sen harrastuksen kautta olla joku toinen porukka. Must se harrastus on kyl tosi tärkee. Et siinä on niïn monta ulottuvuutta.

Nainen 3ov, lapsiperhe

Ja se luo sitä sosiaalisuutta, koska ne on monta kertaa semmoisii yhteisjuttuja vielä, et se luo sitä yhteishenkeä ja sosiaalisuutta.

Nainen 49v, lapsiperhe

Lasten harrastusten vuoksi oltiin valmiita tinkimään muusta:

No, jalkapalloo pelaa nää kaksoispojat. Mutta sïnä säästetään, kun mies on niitten valmentajana. ... Ja se tyttö, nïn kun kasiluokkalainen tyttö pelaa jalkapalloa ihan kilpailumielessä kovasti. Ja sïnä on tosiaan ne maksut monta sataa kuukaudessa sitten kans. Että sitten syyään puuroo.

Nainen 41v, lapsiperhe

Toinen väestöryhmä, jonka harrastusmahdollisuuksilla koettiin olevan merkittävä rooli, olivat eläkeläiset. Ei pidetty riittävänä, että eläkeläinen hoitaa kuntoaan vain kävelemällä tai käymällä esimerkiksi uimahallissa tai kirjastossa, jos sosiaaliset verkostot puuttuvat.

No, mun mielestä eläkeläisil myöskin pitäis olla vähintään yksi harrastus viikossa. Se on kans huolestuttavaa, että kun jää työelämästä pois, nïn helposti loppuu kaikki sosiaalinen kanssakäyminen. ... Sïs vaikka sanotaan toisaalta, että sitten vasta ne kiirreet alkaa, kun pääsee eläkkeelle. Mutta kyllä on nïtäkin eläkeläisiä, joilta sit puuttuu se jokin harrastus. Nïn, se on aika ankeeta.

Nainen 67v, yksinasuva

Harrastusten kustannusvertailuissa lasten halvimmaksi harrastukseksi on osoittautunut partio (jäsenmaksut 60-80 e/vja osallistuminen muutamaan tapahtumaan à 15 e) ja edullisin joukkuelaji oli salibandy (kausimaksu 500-1000 e + vakuutuksen sisältävä lisenssi 100 e). Salibandykustannukset kattava budjetti riittäisi myös mm. kuvataidekouluun, näyttelemiseen, kuoroon ja uintiin. Muut joukkuelajit ovat selvästi salibandya kalliimpia (pesäpallo lähes 2000 e, jalkapalloja koripallo yli $3000 \mathrm{e}$, jääkiekko yli 8000 e) ja myös ratsastus, tanssi ja taitoluistelu ovat sitä kalliimpia. ${ }^{17}$.

Lasten harrastuskustannukset olivat aiemmassa viitebudjetissa hyvin vaatimattomat (200 e/lapsi/v), eikä se nykyään riitä juuri mihinkään kouluikäisten maksulliseen harrastukseen. Keskustelujen ja asiantuntijoiden kommenttien

17 Hinnat perustuvat Iltasanomien (2013) ja Yhteishyvän (2015) laskelmiin lasten harrastusten hinnoista. http//www.is.fi/muutlajit/art-2000000888035, https://www.yhteishyva.fi/arjen-apu/lasten-harrastustenkustannukset/0572883 
jälkeen päädyttiin varaamaan harrastuksiin kullekin kouluikäiselle lapselle 400 euroa vuodessa, mikä on edelleen aika vaatimaton. Keskusteluissa harrastusbudjetin pienuutta perusteltiin sillä, että eri seurat voivat myöntää vähävaraisille alennuksia tai maksuvapautuksia. Harrastuskuluihin voi myös anoa avustuksia. Lähes jokainen harrastus vaatii myös tiettyjä varusteita tai erikoisasusteita, joihin on varattu 60 e vuodessa (120 e/2v). Harrastusbudjettia täydentää jokaisella lisäksi vaatebudjetin sisältämät lenkkitossut, ulkoilupuku ja uimapuku kuten aiemmassakin budjetissa.

Aikuisten harrastuskustannuksiin budjetoitiin aiemman viitebudjetin tapaan erikseen jäsenmaksu, jonka voi käyttää esimerkiksi liikuntaryhmään tai kansalaisopistoon (50 e/v). Lisäksi 50 euroa vuodessa on varattu kulttuuriharrastukseen. Se voi kattaa esimerkiksi yhden teatterilipun ja yhden elokuvalipun tai esimerkiksi noin neljä elokuvissa käyntiä vuodessa. Keskusteluissa korostui se, että ihmisillä on erilaisia kiinnostuksen kohteita, joista pitäisi olla mahdollisuus valita.

Mun mielestä toi nyt kuulostaa hyvältä, et ihmisillä ois mahollisuus yhteen semmoiseen johonkin säännölliseen, vaikka just johonkin jumppaan tai tollaiseen. Ja sit ois mahdollisuus kerran kuussa mennä johonkin sellaiseen, mikä ei ois se aina sun sama harrastus vaan just joku elokuva tai teatteri tai koiranäyttely, tai mihin sä nyt haluat ikinä, mikä sua kïnnostaa. Että mun mielestä semmoinen on ihan hyvä taso.

Nainen 25v, yksinasuva

Vapaa-aikaan katsottiin kuuluvan myös vapaa-ajan matkoja, joskaan kaikki eivät pitäneet niïä aivan välttämättöminä. Useimmat keskustelijat pitivät tärkeänä nün mahdollisuutta yhteydenpitoon kauempana asuviin sukulaisiin ja ystävïn kuin myös irtautumista tavallisesta arjesta kodin ulkopuolelle edes yhdeksi viikonlopuksi vuodessa. Kuten aiemminkin, lasten pääsyä kerran vuodessa huvipuistoon pidettiin tarpeellisena. Mun mielestä ois hyvä, et ihmisellä ois mahdollista pitää yllä noita sosiaalisia suhteita myös sen kotikaupungin ulkopuolella. Että vaikka sulla on se sun kotikaupungin bussilippu, niin sulla ois varaa säännöllisesti käydä tapaamassa vaikka sun vanhempia tai toisessa kaupungissa asuvia sukulaisia tai kavereita. Sillai että sun pitäis jättää tollaisia asioita tekemättä sen takia, että sulla ei oo varaa muuta kun sïhen Helsingin sisäiseen bussilippuun.

Nainen 25v, yksinasuva

Minkä mä budjetoisin itelle välttämättömäksi harrastukseks ja vapaa-aikamenoks, nïn joku ees pien lomamatka, vaikka kerran tai kaks vuoteen joku ihan vaikka viikonloppureissu, vaikka laivamatka tai joku. Et se musta tuntuu, että semmonen irtiotto on ainakin meille jotenkin pakollista, että sitte jaksaa taas.

Nainen 26v, pariskunta 
Sukulaisvierailuihin varattiin kullekin aikuiselle 90 euroa ja lomamatkaan oheiskuluineen 120 euroa vuodessa. Lapsiperheet matkustavat vierailuille ja lomamatkoille omalla autolla, jolloin lomabudjetissa on varaus ainoastaan pieniin oheiskuluihin (40 e/aikuinen ja 10 e/7v+ lapset). Lomabudjettia täydentää yli 5-vuotiailla lapsilla huvipuistoranneke (40 e)ja aikuisilla sisäänpääsyäja muutamaa laitelippua vastaava summa. Niin ikään pienemmille lapsille on varattu raha muutamaan laitelippuun.

Vapaa-ajanbudjettiin varattiin aiempien viitebudjettien tapaan rahaa myös joulu- ja syntymäpäivälahjoihin. Niin omille lapsille (100 e/v/lapsi) kuin sukulaisille (50 e/v) ja omien lasten kaverien syntymäpäiville (3 x 10 e/v). Leluja ja pelejä ei ole budjetoitu erikseen, vaan niiden on ajateltu sisältyvän lahjoihin. Taulukkoon 11 on koottu vapaa-ajan budjetit eriteltyinä ja yksityiskohtaisemmat tiedot löytyvät liitteestä 1 .

Taulukko 11. Vapaa-ajan ja harrastusten kustannukset kotitaloustyypeittäin vuonna 2018, e/kk.

\begin{tabular}{|c|c|c|c|c|c|}
\hline & $\begin{array}{c}\text { Kotimaan } \\
\text { matkat ja } \\
\text { vierailut, } \\
€ / \mathbf{k k}\end{array}$ & $\begin{array}{l}\text { Liikunta- } \\
\text { varusteet, } \\
€ / \text { kk }\end{array}$ & $\begin{array}{c}\text { Kulttuuri- } \\
\text { harrastukset, } \\
\text { kausi- ja } \\
\text { jäsenmaksut, } \\
€ / \text { kk }\end{array}$ & $\begin{array}{c}\text { Lahjat, } \\
\text { kynät, } \\
\text { paperi- } \\
\text { tavarat, } \\
\text { yms.,€/kk }\end{array}$ & $\begin{array}{c}\text { Yhteensä, } \\
€ / \mathbf{k k}\end{array}$ \\
\hline Yksin asuva alle $45 \mathrm{v}$ & 18 & 5 & 13 & 13 & 48 \\
\hline Yksin asuva yli $65 \mathrm{v}$ & 18 & 5 & 13 & 15 & 50 \\
\hline Pari, yli 50 v työssä & 35 & 10 & 25 & 20 & 90 \\
\hline $\begin{array}{l}\text { Pari, nainen yli } 50 v \text { työssä, } \\
\text { mies yli } 65 \text { v eläkkeellä }\end{array}$ & 34 & 10 & 25 & 20 & 88 \\
\hline Pari, yli 65 v eläkkeellä & 32 & 10 & 25 & 22 & 89 \\
\hline YH-perhe, yksi leikki-ikäinen & 21 & 5 & 13 & 20 & 58 \\
\hline YH-perhe, kaksi teini-ikäistä & 48 & 15 & 79 & 33 & 176 \\
\hline Pikkulapsiperhe, kaksi lasta & 16 & 20 & 25 & 34 & 95 \\
\hline Lapsiperhe, kaksi lasta & 18 & 20 & 58 & 34 & 130 \\
\hline Teiniperhe, kaksi lasta & 20 & 20 & 92 & 34 & 166 \\
\hline Teiniperhe, kolme lasta & 25 & 25 & 125 & 45 & 220 \\
\hline
\end{tabular}

Lapsiperheiden kuvaukset: YH-perhe yksi leikki-ikäinen: äiti ja 3-v. tyttö; YH-perhe kaksi teini-ikäistä: äiti, 10-v. poika ja 13-v. tyttö; Pikkulapsiperhe: äiti, isä, poika 2 v ja tyttö 6 v; Lapsiperhe: äiti, isä, 4-v. poika ja 10-v. tyttö; Teiniperhe kaksi lasta: äiti, isä, teini-ikäistä: 14-v. tyttö ja 16-v. poika; Teiniperhe kolme lasta: äiti, isä, 10-v. poika, 15-v. poika ja 17-v. tyttö (ks. luku 3.) 
Aiemmassa budjetissa vapaa-ajan kustannukset olivat hyvin vaatimattomat. Keskustelijat korostivat harrastusten merkitystä hyvinvointiin ja pitivät kohtuullista harrastusbudjettia tärkeänä. Harrastusbudjettia on nyt korotettu aiemmasta hieman kustannusten nousua enemmän, jotta se mahdollistaa jokaiselle kouluikäiselle edes jonkun maksullisen, säännöllisen harrastuksen. Myös vapaa-ajan matkoihin on varattu hieman aiempaa enemmän. Matkabudjetin ruoat ja juomat sisältyvät ruokabudjettiin. Oman auton omistavat lapsiperheet käyttävät autoa vierailu- ja lomamatkoihin. Muissa talouksissa puolestaan on kaikille budjetoitu matkaliput, mikä kasvattaa erityisesti yhden huoltajan talouden matkakuluja. Vapaa-ajan budjetit ovat kasvaneet kaikissa kotitaloustyypeissä selvästi verrattuna aiempaan viitebudjettiin (vrt. Lehtinen \& Aalto 2014).

Vapaa-ajan budjetti on edelleen vaatimaton verrattuna vuoden 2016 kulutustutkimukseen. Useimmilla esimerkkitalouksilla viitebudjetti kattaa noin kolmasosan vastaavien kotitalouksien vapaa-ajan keskikulutuksesta ja alle puolet neljän alimman tuloluokan keskikulutuksesta.

Kuluttajien kanssa keskusteltiin myös siitä, pitäisikö lemmikkieläin sisällyttää viitebudjettiin. Joillekin lemmikki oli hyvin tärkeä, mutta sen pitämisen todettiin olevan kallista. Lemmikin katsottiin kuuluvan lähinnä harrastuksiin.

Mutta se [lemmikki] osittain liittyy kyllä sit myös tohon nïn kun harrastustoimintaan.

Mies 52v, pariskunta

Viimeisimpien tutkimusten mukaan (Tilastokeskus 2016, Taloustutkimuksen kysely $^{18}$ ) joka kolmannella suomalaisella on kotonaan lemmikkieläin tai -eläimiä. Joka toisessa lapsiperheessä on lemmikki, kun taas sinkkutalouksissa niitä on vain 18 prosentilla. Laskelmat osoittavat, että koiran kustannukset ovat kuukaudessa noin 150 euroa ja kissan yli 110 euroa ruokineen ja lääkärikuluineen, vaikka hankintakuluja ei oteta huomioon (Petnets 2015). Viitebudjetin vaatimattomat harrastuskulut eivät useimmilla talouksilla kuitenkaan riitä tavanomaisiin lemmikin kuluihin (vrt. Taulukko 11). Lemmikkienomistajat joutuvat siten tinkimään jostain muusta, kuten keskusteluissa pohdittiin.

Sanotaan, et kyl se [lemmikki] on semmonen merkittävä. Jos on vaikka joku perheellinen tai yksineläjä, nïn sille saattaa olla nïn paljon suurempi merkitys, et hän tinkii omasta ruuastansa, jotta hänellä on se kaveri.

Mies 62v, pariskunta

18 https://www.taloustutkimus.fi/ajankohtaista/uutisia/suomalaiset-ovat-koiraihmisia.html?utm source=Marraskuun+uutisia\&utm medium $=$ email\&utm campaign $=$ 
No, mä oon sitä mieltä, että jos eletään minimibudjetilla, niïn kyl sïn pitää ennen sitä lemmikin hankkimista miettii just se, et se ei pelkästään rïtä se et mä saan ilmatteeks tosta sen kissanpennun.

Nainen 27v, yksinasuva

Useimmat keskustelijat olivat sitä mieltä, että lemmikkien kuluja ei tule sisällyttää viitebudjettiin, joten ne eivät ole budjetissa mukana.

\subsection{ASUMINEN}

Asumisen kustannukset ovat jo pitkään olleet suurin menoerä kotitalouksien kulutuksessa (esim. Nurmela \& Parikka 2018) ja erityisen suuret ne ovat kaupunkimaisissa kunnissa (Ilmarinen \& Kauppinen 2018). Kustannukset vaihtelevat selvästi myös eri puolilla maata ja erikokoisissa kaupungeissa. Asumistarpeet vaihtelevat elämän eri vaiheissa. Aina ei kuitenkaan ole mahdollista vaihtaa edullisempaan asuntoon, vaikka haluaisi. Asuminen on viitebudjetissa erillisenä osana, jotta alueellisia eroja voidaan ottaa huomioon edes keskimääräisenä. Asumiskustannuksiin vaikuttaa lisäksi se, asutaanko kaupungin keskustassa, lähiössä vai haja-asutusalueella. Alueiden sisäisiä eroja tai muita asumiskustannuksiin vaikuttavia tekijöitä tai erilaisia asumismuotoja ei ole voitu ottaa viitebudjeteissa huomioon. Suurin osa suomalaisista asuu omistusasunnoissa ja noin neljäsosa asuu vuokralla (Tilastokeskus 2017a). Kuitenkin pienituloisista kotitalouksista (kolmeen alimpaan tulokymmenykseen kuuluvista) vuokralla asui yli 6o prosenttia (Kauppinen ym. 2015). Aiempien viitebudjettien tapaan asumiskulut on laskettu vuokra-asumiselle.

Vuokra-asunnoissa pinta-alaa henkilöä kohden on vähemmän kuin omistusasunnoissa. Vuokralla-asuvilla on käytössä keskimäärin 32 neliömetriä ja omistusasunnoissa 43 neliömetriä henkilöä kohden. Kullakin asuntokunnalla ${ }^{19}$ on keskimäärin 40 neliömetriä henkilöä kohden (yhden henkilön taloudet $60 \mathrm{~m}^{2} /$ henkilö-5 henkilöä 24,5 m²/henkilö). (Tilastokeskus 2017a)

Ryhmäkeskustelijat eivät pitäneet tiettyä neliömäärää ratkaisevana asunnon ominaisuutena. Sen sijaan he korostivat sitä, että useamman henkilön asunnossa tarvitaan väliseiniä ja perheenjäsenille omaa rauhaa, joten yksiön katsottiin soveltuvan vain yksin asuville. Seuraavassa esimerkkejä asuntoon liittyvistä pohdinnoista eri ryhmäkeskusteluista:

19 Asuntokunta käsittää samassa osoitteessa tai asunnossa asuvat henkilöt. Siihen voi kuulua useita kotitalouksia, esim. kimppakämpässä asuvat. 
No sanotaan näin että tuota, et meitä on kaks henkeä minä ja vaimo, nïn kyllä se ihan mukava on, että kummallekin oma huone löytyy sïnä vaiheessa, jos napit mennee vastakkain. Nïn ois se, jos sanotaan yksiössä asuttais, että jossa tilaa on sillai nïn aika nihkeästi. Nïn kyllä se ihan mukavaa on, että siihen saa semmoisen pienen hajuraon. Muutenkin nïn, minusta vähän väljempi asuminen tuo myös asumisiloa, ettei tartte elää sillai sohva telkkarissa kiinni ja telkkari nostettuna vielä seinälle tai jotakin vastaavaa. Ja puhumattakaan, että nukkumistila on sïnä olohuoneen kans samassa tilassa. Nïn ei tämmöisiä ratkaisuja mieluusti. Että olohuone olohuoneena ja makkari makkarina ja tämmöisiä, että kyllä se ihan semmoista ihan käyttömukavuutta on, ja arjen sujumisen kannalta on mukavaa. Jos toinen on vaikka töissä, nün se, että sie kattelet telekkaria yöllä sïnä vieressä, jos ei oo kuulokkeita. Nïn kyllä se jää kattomatta sitten- todennäköisesti ainakin, jos kunnioittaa pariansa. Niin arjen käytön mukavuuden kannalta nïn tila on aina hyväksi.

Mies 4ov, pariskunta

Meillä oli, edellinen asunto oli semmonen, mistä näky koko asunto joka kulmasta suunnilleen siis, 45 neliöö. Mut se, että sïnä ei ollu esimerkiks semmosta, et toinen halus mennä nukkuun aikaseen ja ite haluaa vielä olla hereillä, ja sitten se on valaistu. Nïn, se oli aika tuskasta välillä. Nïn, huomattiin, et sitten muutettiin, et on nï̈kun muutama väliovi ja näin, nüin se on tosi paljon mukavempaa. Nyt kun sïhen tuli se pieni lapsi viäl, nïn se on viäl tärkeempää, et pystyy eristäytyyn välillä yksin aina vuorotellen.

Mies 42v, lapsiperhe

En mä oikein tiä, missä vaiheessa [lapsi tarvitsee oman huoneen]. Mutta sïs ei mun mielestä nyt ihan joka lapsi välttämättä tarvitse täysin omaa huonetta. Et voihan se olla vaikka jaettavissakin joku isompi huone kahdelle. Meillä nyt on kaikille omat huoneet, mutta se vaan on näin. ... Mutta kyllä totta on se, että sitten varsinkin kun teini-ikää lähestyy lapsi, nïn hän tarvitsee jonkun oman paikan missä olla. Että ei se nyt ihan oo nïn, että täs nyt ollaan olohuoneessa, nukutaan kaikki, vaan onhan se totta, et oman paikan tarvii.

Nainen 4Ov, lapsiperhe

Vähän vastaava. Yleensä se oma huone on kaikkein helpoin ja paras ja turvallisin, mihin voi kiinnittää ne omat julisteet ja missä voi tehä ja olla. Ja jos sua kiukututtaa, voit mennä sinne suutuspäissäs kiukutteleen ja muuta.

Nainen 27v, yksinasuva

Osa keskustelijoista piti erityisesti arvossa asunnon sijaintia keskustassa, jolloin asunnon tilavuudesta oltiin valmiita tinkimään. Iäkkäämmille taas muuttaminen vanhasta asunnosta ja tutusta ympäristöstä on vaikeaa, vaikka tilaa olisi enemmän kuin tarvitsee: 
Kyl sïainti minusta on tärkeetä. Mut sekin jo merkkaa eri ihmisille eri asiaa, että joku tykkää kerrostalosta keskustassa, joku tykkää vähän lähempänä luontoa olla ja näin. Mut sïs mun mielestä kuitenkin sïs semmoinen kunnollinen asuminen on tärkeetä, että ei vedä eikä vïraa mistään. Ja se et on turvallinen ympäristö sillä tavalla, että sïnä ei tarvi ympäristön kautta potea mitään lähiöristirïtoja tai pelkää mennä kotiin tai muuta. Et se on se turvallisuus. Se sitten mihin kelläkin on varaa, nïn se on tietysti toinen juttu. ... Ja se myöskin on asia,joka varmaan elää joka ihmisen kohdalla aina elämäntilanteen mukaan.

Nainen 65v, pariskunta

Niin joo se on sillai vaikee, että mäkin oon jäänyt yksin asumaan semmoiseen perheasuntoon, kun mies on kuollut ja lapset on muuttanut pois. Nïn en mä sit osaa muuttaa siitä pois. Mutta jotenkin kun sïnä on nïn kauan asunut.

Nainen 69v, yksinasuva

Aika paljon oon just huomannut, et tääl nykyään nïstä neliöistä ollaan valmiita tinkimään. Ja Helsingissä pakko, kun on niin kallista. ... Mut toisaalta sit taas kaikil muilla on lähes tulkoon se sama tilanne, et ne lapset oppii sïhen, mitä ne näkee. ... Et mä haluun asuu suht koht lähellä keskustaa ja mä oon silloin valmis tinkimään nüistä neliöistä.

Nainen 42v, lapsiperhe

\section{Viitebudjettitalouksien asunnot ja vuokra}

Viitebudjettitalouksien asuntojen koot määriteltiin mukaillen kunkin elinkaarenvaiheen tyypillistä asumista Suomessa. Yhden henkilön viitebudjettitalouksista alle 45-vuotiaat asuvat yksiössä ja yli 65-vuotiaat sekä yhden lapsen yksinhuoltajatalous kaksiossa. Parit, kahden teinin ja yhden huoltajan perhe sekä pikkulapsiperhe asuvat kolmiossa ja muut 4-5 henkilön lapsiperheet asuvat neljän huoneen ja keittiön asunnossa.

Viitebudjettitalouksissa kaikilla lapsilla ei ole omaa huonetta. Asuntojen koko on kuitenkin sellainen, että korkeintaan kaksi lasta asuu samassa huoneessa ja vanhemmilla on yhteinen makuuhuone. Asunnon huonelukumäärä ja neliöt oli tarpeen määritellä, koska ne vaikuttavat vuokrakustannusten lisäksi myös esimerkiksi energiakustannuksiin ja siihen, miten paljon tarvitaan valaisimia, verhoja ja mattoja tai muita kussakin huoneessa tarvittavia sisustustarvikkeita.

Koska käytettävissä ei ole erilaisten kotitalouksien tai erikokoisten asuntojen kuukausivuokria eri alueilla, päädyttiin käyttämään yksiöiden, kaksioiden, kolmioiden ja neliöiden (4 huonetta ja keittiö) keskikokoihin perustuvia keskimääräisiä neliövuokria. Näin pyrittiin pääsemään mahdollisimman lähelle keskimääräisiä alueellisia asumiskustannuksia. Helsingissä asutaan ahtaimmin ja muualla 
Suomessa väljimmin. Erot eivät kuitenkaan olleet kovin suuria. Vuokra-asuntojen keskikoot eri alueilla (Taulukko 12) saatiin Tilastokeskuksesta. Muualla Suomessa vuokra-asuntoja on selvästi vähemmän kuin pääkaupunkiseudulla. Laskelmissa käytetään jaottelua neljään luokkaan: Helsinki, Pääkaupunkiseutu, yli 100000 asukkaan kaupungit ja muu Suomi (koko maan keskiarvo, josta Pääkaupunkiseutu on jätetty pois).

Taulukko 12 . Vuokra-asuntojen alueellinen keskikoko $\left(\mathrm{m}^{2}\right)$ asuntotyypeittäin 2016.

\begin{tabular}{|lcccc|}
\hline Alue & Yksiö, m2 & Kaksio, m2 & $\begin{array}{c}\text { Kolmio, } \\
\text { m2 }\end{array}$ & Neliö, m2 \\
\hline Helsinki & 31 & 50 & 73 & 92 \\
\hline Pääkaupunkiseutu & 32 & 51 & 72 & 92 \\
\hline Yli 100 000 asukasta & 32 & 51 & 72 & 92 \\
\hline Muu Suomi & 33 & 52 & 73 & 95 \\
\hline
\end{tabular}

(Laskelma Tilastokeskus 2017. Vuokra-asuntojen keskikoko eri alueilla.)

Kuukausivuokrat eri asuntotyypeille on laskettu alueellisten asuntotyypittäisten keskineliövuokrien pohjalta, vapaarahoitteisille vuokra-asunnoille vuoden 2018 elokuussa (Taulukko 13). Koska neliöiden vuokria ei ollut erikseen käytettävissä, niille käytetiin saman alueen kolmion keskivuokraa. Tilastokeskus julkaisee tietoja keskineliövuokrista kolme kertaa vuodessa. Vuokra-asuntotyyppien keskikoossa ei eri puolilla maata juuri ole eroa, mutta neliövuokrat ovat selvästi erisuuruiset, minkä seurauksena kuukausivuokrissa on suuret alueelliset erot(Taulukko 13). Helsingissä ja pääkaupunkiseudulla vuokrat ovat selvästi muuta maata korkeammat.

Taulukko 13. Kuukausivuokrat alueellisten vapaarahoitteisten vuokra-asuntojen keskivuokrien ja keskikokojen perusteella asuntotyypeittäin, e/kk.

\begin{tabular}{lcccc}
\hline Alue & Yksiö, $€ /$ kk & $\begin{array}{c}\text { Kaksio, } € / \\
\mathbf{k k}\end{array}$ & $\begin{array}{c}\text { Kolmio, } \\
€ / \mathbf{k k}\end{array}$ & Neliö, $€ /$ kk \\
\hline Helsinki & 738 & 922 & 1176 & 1490 \\
\hline Pääkaupunkiseutu (PKS) & 733 & 896 & 1128 & 1426 \\
\hline Yli 100 000 asukasta & 594 & 724 & 932 & 1180 \\
\hline Muu Suomi (koko maa - PKS) & 487 & 605 & 740 & 952 \\
\hline Koko maa, vuokra-asunnot & 571 & 684 & 856 & 1106
\end{tabular}

(Lähde: Tilastokeskus 2018a) 


\section{Vuokrien määrittämistä tarkennettu}

Aiemmin vuokran määrittelyn taustalle määritettiin asuntotyyppi ja sen neliöt kullekin viitebudjettitaloudelle. Vuokra laskettiin alueen vapaarahoitteisten asuntojen keskivuokran perusteella samalla neliövuokralla (Lehtinen ym. 2010; Lehtinen \& Aalto 2014). Nyt kullekin viitebudjettitaloudelle määritettiin vain asunnon tyyppi ja sille haettiin tilastoista kunkin alueen keskikoko ja keskineliövuokra. Näin voitiin ottaa huomioon se, että yksiöiden neliövuokrat ovat kokonaiskeskivuokraa kalliimmat ja isompien asuntojen puolestaan edullisemmat. Lisäksi Tilastokeskuksen tilastot osoittavat, että pääkaupunkiseudun ulkopuolella asuntojen keskikoko on hieman suurempi, mutta neliövuokra edullisempi kuin pääkaupunkiseudulla.

Uusi laskentatapa pienensi asumiskuluja, koska asuntojen laskennalliset keskikoot ovat nyt pienempiä kuin aiemmissa viitebudjeteissa. Myös yksiöissä viitebudjettitalouksien vuokrat laskivat, vaikka neliövuokrat olivat selvästi aiempaa suuremmat, koska niiden koko pieneni 45 neliöstä 31-33 neliöön. Kolmioiden (73 m²) ja neliöiden $\left(92 \mathrm{~m}^{2}\right.$ ) keskikoot olivat lähes samat kuin aiemmissa viitebudjeteissa $\left(75 \mathrm{~m}^{2}\right.$ ja $\left.92 \mathrm{~m}^{2}\right)$. Viitebudjetin lapsiperheiden asumiskulut kuitenkin pienenivät lähinnä siksi, että suurten asuntojen neliövuokrat ovat aiemmin käytettyä alueellista keskivuokraa pienempiä. Lisäksi kolmen teini-ikäisen ja vanhempien perhe asuu nyt saman suuruisessa asunnossa ( $92 \mathrm{~m}^{2}, 4$ huonetta ja keittiö) kuin esimerkiksi kahden teini-ikäisen ja kahden vanhemman perhe, kun aiemmin viiden hengen perheellä oli noin 10 neliötä suurempi asunto.

Mikäli olisi käytetty aiempaa laskentatapaa eli asuntotyypeittäin vakioituja asuntojen kokoja ja samoja alueellisia keskivuokria erikokoisille asunnoille, vuokrat olisivat kallistuneet selvästi kaikissa asunnoissa. Helsingissä ja muualla pääkaupunkiseudulla vuokrat olisivat kaikilla kallistuneet yksiöissä noin 100 euroa ja isoissa asunnoissa noin 250 euroa kuukaudessa. Yli 100 ooo asukkaan kaupungeissa vuokrat olisivat kohonneet noin puolet vähemmän kuin Helsingissä ja pääkaupunkiseudulla.

\section{Energiakustannukset ja kotivakuutus}

Asumiseen kuuluvat myös energiakustannukset, jotka muodostuvat energian kulutuksen mukaisesta sähkön hinnasta ja energian siirtomaksusta. Sähkönlaskun keskimääräinen kilowattitunnin kokonaishinta vuoden 2018 tammikuussa oli 19,6 senttiä/kWh (o,196 e/kWh). Koko maan verollinen, nimellinen kokonaishinta (siirto- ja energiahinnat) laskettiin energiaviraston laskurilla ${ }^{20}$, jossa tyyppikäyttäjävaihtoehdoksivalittiin kerrostaloasunto. Siinäainoavaihtoehtosähkönkulutukselle

20 http://www.sahkonhinta.fi/summariesandgraphs 
on 2000 kWh/v. Sähköenergian osuus sähkölaskusta on tyypillisesti 40-50 prosenttia sähkölaskusta. Kuluttaja voi kilpailuttaa sähköenergian tarjoajia, mutta ei sähkösiirtoa.

Samaa kilowattituntihintaa (o,196 e) käytetiin kaikilla kotitalouksilla. Energiankulutus puolestaan on määritetty talouden koon mukaisesti erilaisten kotitalouksien tyypillisen sähkön kulutuksen mukaan kerrostaloissa (ks. Adato 2013). Sähkön vuosikulutus vaihtelee viitebudjettitalouksissa yhden henkilön talouden 1400 kilowattitunnista viiden henkilön talouden 6000 kilowattituntiin. Kuukauden sähkölasku on yhden hengen talouksilla 23 euroa ja viiden hengen talouksissa 98 euroa kuukaudessa.

Lisäksi asumismenoihin sisältyy kotivakuutus. Kotivakuutus on pakollinen vuokra-asunnossa ja sen suuruus riippuu asunnon koosta ja vakuutuksen laajuudesta. Siihen sisältyvät aina oikeusturva- ja palovakuutukset. Hintaan vaikuttaa myös se, mistä arvosta irtaimisto on vakuutettu ja millaisessa talossa asuu. FINEn (2017) vertailussa vakuutuksen hinta vaihtelee Helsingissä noin 30 neliön yksiössä 129-190 euroa vuodessa. Hintaan vaikuttaa myös asunnon sijainti. Pääkaupunkiseutu on tässäkin kallein. Vakuutusyhtiöstä riippuen ero voi edullisimmissa kotivakuutuksissa olla 10-30 euroa. Asunnon koko puolestaan lisää vakuutuksen hintaa melko suoraviivaisesti eri vakuuttajilla (Pankkiasiat 2014). Viitebudjettiin on arvioutu maan keskiarvoa vastaavat kotivakuutusten hinnat vaihdellen asunnon koon perusteella yksiön 130 eurosta neliön 225 euroon vuodessa.

Sekä energia että kotivakuutus on sisällytetty perusbudjettiin ja vuokrakulut ovat erillisenä eränä.

\subsection{LIIKKUMINEN}

Aiempien viitebudjettien tapaan kohtuullisen minimin viitebudjetit nojautuvat vahvasti julkisen liikenteen käyttöön ja pyöräilyyn. Joukkoliikennekulut ovat erillisenä eränä, koska mahdollisuudet sen käyttöön vaihtelevat suuresti, samoin liikkumistarpeet. Harvaan asutuilla seuduilla tai kaikissa kaupungeissakaan ei ole tarjolla sujuvaa joukkoliikennettä, joten siellä käytännössä kaikki tarvitsevat oman auton tai ovat pidemmillä matkoilla muutaman kerran viikossa liikennöivien palvelulinjojen tai muiden kuljetusavun varassa. Moni koki myös, että ilman autoa ei pystyisi osallistumaan harrastuksiin tai se vaikeuttaisi työmatkoja ja lasten kuljetuksia merkittävästi.

Joukkoliikenteen käyttömahdollisuuksista ja auton välttämättömyydestä keskusteltiin paljon: 
Se rïppuu tosi paljon asunnon sijainnista ja elämäntilanteesta missä voi olla ilman autoa, sitten perhe tai voi olla epätyypilliset liikkumisajat tai muut. Nïn en mä sitä sano, etteikö auto monelle pääkaupunkiseudullakin olis tarpeellinen, missä on pääsääntöisesti tosi hyvät julkiset yhteydet. Mut et mä ite taas oon kokenut, että mulle huomattavasti halvempaa on se, että käyttää julkisia ja liikkuu pyörillä.

Mies 29v, yksinasuva

Työmatka tai just vuorotyöt ja tämmöiset nün voi olla tai pienten lasten kuljettaminen kahteen päiväkotiin tai jotain vastaavaa. Nïn ne on sellaisia, jotka aika pitkälle puoltaakin omaa autoa. Mutta sehän on semmoinen asia jonka voi sitten myöskin elämäntilanteen mukaan muuttua.

Nainen 65v, yksinasuva

Meillä on ollut kans mun miehen työnkin takia se tarttee. Sillä on ollut semmoiset työajat, et se ois aika mahdotontakin ilman autoa se liikkuminen. Mut kyl mä sanon sïnä vaiheessa, kun meiän lapset on ollut pienii. Nïn en mä tiiä kyl mun mielestä se ois ollut hankalaa meiän kaikki kauppareissut [ilman autoa]. Isolle porukalle kuitenkin tulee ostettua nïn paljon. Et sä saa niitä millään raahattua. Vieläkin kyllä tulee ja sitten toinen on mun mielestä ollut kaikki reissut, kesälomareissut mitä ollaan tehty sïs Suomessa. Jos mennään jonnekin mökille tai jonnekin kylään tai jotain. Niin kyllä se aika hankalaa ois ollut pakkaa kaikki neljä ja sit vielä jotkut vaunut sun muut mukaan ja lähtee aina niitten kaikkien kanssa. Ja sit plus kassit ja kaikki. Auto on kuulunut osana sïhen meiän perheeseen. Ja meillä oli silloin isompi tietenkin, kun meitä oli nïn monta. Nïn meillä oli semmoinen pikkubussi, semmoinen oli pakko olla. Silloin kun mä huomasin et mä odotan neljättä, nïn sehän oli välttämättömyys hommaa joku tila-auto tai jotain, koska ei me oltais mahuttu muuten mihinkään. Sit meillä on vielä koira ja kolme kissaa.

Nainen 42v, lapsiperhe

No sïs jos vähänkään kaupungin ulkopuolella asut, nïn ei julkinen liikenne kulje kunnolla. Opiskeluaikana jo se oli ihan kauheeta. Ei voinu olla minkään näköstä opiskelijaelämää. Ei voinu kaveerata täällä olevien ihmisten kanssa kunnolla, kun koulun jälkeen täyty juosta sïhen bussïn. Muuten sul menee kaks tuntia siihen, kun sä joudut odottaan seuraavaa.

Nainen 27v, yksinasuva

Auton tarpeesta oli monenlaisia mielipiteitä:joidenkin mielestä se pitäisi olla kaikilla ja joidenkin mielestä sitä ei isoissa kaupungeissa tarvitse juuri kukaan. Useimpien mielestä auto on lapsiperheissä tarpeen ja muillakin kaupunkitaajamien ulkopuolella asuvilla. Vuoden 2012 kulutustutkimuksen mukaan lähes kaikilla lapsiperheillä (97 \%) oli oma auto ja joka toisella jopa kaksi autoa. Yhden huoltajan talouksista 
auton omisti noin 70 prosenttia ja kaikista talouksista keskimäärin hieman useampi.Viimeisimmän kulutustutkimuksen mukaan auton omistavien kotitalouksien osuudet ovat pysyneet viime vuosina lähes ennallaan. (Tilastokeskus 2016.)

Keskustelujen pohjalta ja tilastojen tukemana keskihintainen auto on lapsiperheiden viitebudjettikuluissa mukana. Oletuksena on, että autolla ajetaan 15000 kilometriä vuodessa. Laskelmien mukaan autoilun keskimääräiset kustannukset ovat 0,36 euroa kilometriä kohden (juoksevat kulut 0,19 e/km). Auton vuosikustannukset ovat 5400 euroa, eli kuukaudessa 450 euroa. ${ }^{21}$ _Auton kulut voi tarvittaessa lisätä yksilölliseen budjettiin tai poistaa siitä ja vaihtaa ne aikuisen joukkoliikenteen kuukausilippuun. Vapaa-ajan yhteisillä lomamatkoilla kahden huoltajan lapsiperheiden oletetaan käyttävän omaa autoa, mikä pienentää matkakuluja yksinhuoltajatalouksiin verrattuna.

Jokaiselle yli 6-vuotiaalle perheenjäsenelle on varattu polkupyörä ja sen varusteita kuten esimerkiksi kypärä ja lukko. Keskustelijat pitivät myös ajoittaista vuosihuoltoa tärkeänä, joten se otettiin uutena menoeränä mukaan joka toiselle vuodelle. Alle 4-vuotiaille lapsille on varattu pyörään lastenistuin ja edulliset rattaat.

Viitebudjetin erillisenä eränä ovat alueen sisäisen liikenteen kuukausilippujen kulut kaikille perheenjäsenille kouluikäisestä lähtien. Lapsiperheissä toiselle aikuiselle ei ole joukkoliikennelippua, koska hänen oletetaan käyttävän pääsääntöisesti omaa autoa. Erillisen erän toisena vaihtoehtona on naapurikunnat kattava, laajemman alueen lippu (seutulippu), jonka kustannukset on laskettu vain aikuisille, lapsiperheissä toiselle aikuiselle.

Aiempiin viitebudjettien päivityksiin verrattuna kaupunkien sisäisten kuukausilippujen hinnat ovat samankaltaistuneet huomattavasti. Lähes kaikissa suurissa ja suurehkoissa kaupungeissa aikuisten kaupungin sisäinen 30 päivän lippu maksoi vuoden 2018 keväällä noin 50-60 euroa (Pääkaupunkiseudun kaupungeissa 54,7 euroa) tai vastaava kuukausilippu kattoi vähintään pari vyöhykettä niissä kaupungeissa, joissa hinnoittelu oli vyöhykeperustainen. Laajemman alueen kattava 30 päivän lippu maksoi 90-110 euroa (Pääkaupunkiseudulla seutulippu 106,5 e) (HSL 2018).

Alennuslippujen hinnoissa, kohderyhmissä ja lasten lipun ikärajoissa oli vaihtelua kaupunkien välillä. Monissa kaupungeissa yli 65-vuotiaat saivat matkustaa kello 9-14 noin puoleen hintaan tai heidän kuukausilippunsa maksoi noin 80 prosenttia aikuisen lipun hinnasta. Lasten lippu maksoi useimmilla paikkakunnilla puolet aikuisten lipun hinnasta ja osassa kaupunkeja alle 7-vuotias sai aikuisen seurassa matkustaa ilmaiseksi. Lastenlipun tavanomaiset ikärajat olivat 7-16 tai

21 https://www.kauppalehti.fi/uutiset/autoilun-todellinen-hinta-nain-paljon-auton-omistaminen-maksaa/ Y27A3wHu; https://autocosts.info/FI (laskentamalli) 
6-17 vuotta. Muutamissa kaupungeissa (esim. Tampere, Turku, Jyväskylä, Oulu) on nuorille ja opiskelijoille (esim. 17-24- tai 15-19-vuotiaat) oma lippunsa, jonka arvo oli 70-80 prosenttia aikuisten lipun arvosta.

Viitebudjettilaskelmissa kaupungin sisäisen joukkoliikenteen 30 päivän lipun hintana on aikuisilla 55 euroa ja aluelipun hintana 106 euroa. Lasten lipun (7-17-vuotiaat) hinnaksi on laskettu puolet ja yli 65- vuotiaille 80 prosenttia aikuisten lipun hinnasta. Mikäli perheessä on auto, toiselle aikuisista ei ole laskettu kuukausilipun kustannusta. Eläkeläiset eivät välttämättä tarvitse joukkoliikennettä joka päivä, mutta eläkeläiskuukausilipun arvon budjetoinnin on arvioitu mahdollistavan muutaman taksimatkan vuodessa.

Taulukkoon 14 on koottu sekä julkisen liikenteen että polkupyörän ja auton kustannukset viitebudjettitalouksille. Autoilun kustannukset (450 e/kk) kasvattavat liikkumisen kuluja huomattavasti verrattuna 55 euron julkisen liikenteen kuukausilippuun (Taulukko 14). Liikkumisen kulut vaihtelivat yksin asuvien eläkeläisten 52 eurosta viisihenkisen teiniperheen noin 630 euroon kuukaudessa. Mikäli joukkoliikennelipun tilalle valitaan auto myös muille aikuisille, se kasvattaa kuluja kunkin osalta noin 395 euroa kuukaudessa.

Taulukko 14. Liikennekustannukset kotitaloustyypeittäin vuonna 2018, e/kk.

\begin{tabular}{|c|c|c|c|c|}
\hline & $\begin{array}{c}\text { Julkinen liikenne, } \\
€ / \mathbf{k k}\end{array}$ & $\begin{array}{l}\text { Polkupyörä, huolto } \\
\text { ja varusteet, } € / \text { kk }\end{array}$ & $\begin{array}{c}\text { Auton käyttö } \\
€ / \mathbf{k k}\end{array}$ & $\begin{array}{l}\text { Yhteensä, } \\
€ / \mathbf{k k}\end{array}$ \\
\hline Yksin asuva, alle $45 \mathrm{v}$ & 55 & 8 & 0 & 63 \\
\hline Yksin asuva, yli $65 \mathrm{v}$ & 44 & 8 & 0 & 52 \\
\hline Pari, yli 50v työssä & 110 & 16 & 0 & 126 \\
\hline $\begin{array}{l}\text { Pari, nainen yli } 50 v \text { työssä, } \\
\text { mies yli } 65 \text { v eläkkeellä }\end{array}$ & 99 & 16 & 0 & 115 \\
\hline Pari, yli 65 v eläkkeellä & 88 & 16 & 0 & 104 \\
\hline YH-perhe, yksi leikki-ikäinen & 55 & 15 & 0 & 70 \\
\hline YH-perhe, kaksi teini-ikäistä & 110 & 25 & 0 & 135 \\
\hline Pikkulapsiperhe, kaksi lasta & 55 & 27 & 450 & 532 \\
\hline Lapsiperhe, kaksi lasta & 83 & 31 & 450 & 563 \\
\hline Teiniperhe, kaksi lasta & 110 & 33 & 450 & 593 \\
\hline Teiniperhe, kolme lasta & 138 & 41 & 450 & 629 \\
\hline
\end{tabular}

Lapsiperheiden kuvaukset ks. luku 3. 
Helsinkiläiset keskustelijat ottivat esiin myös yhteiskäyttöautot. Keskustelussa todettiin kuitenkin, että niitä on toistaiseksi vain isojen kaupunkien keskusta-alueilla kätevästi saatavilla. Ne ovat ehkä tulevaisuudessa käyttökelpoinen vaihtoehto kaupungeissa, mutta ei vielä nyt.

Voi olla oikein hyvin [ilman autoa]. Meillä ei oo myöskään autoa mutta ollaan hyvin liikkuvaista sorttia. Keskustassa kun asuu nïn tää julkisen puolen on äärettömän toimivat Helsingissä. ... Silloin kun autoa tarvii, auton saa aika helposti vuokrattua tai lainattua. Paljon on erilaisii autotämmöisiä kimppa, vuokraus, kimppakyytipalvelujakin silloin harvoin kun tarvii.

Mies 37v, pariskunta

Viitebudjetin kulkuneuvot ja laskentaperusteet on pidetty pitkälti samoina kuin aiemmin. Muutoksina polkupyörän vuosihuollon lisääminen kuluttajien tarpeellisena pitämänä palveluna (joka toinen vuosi) ja lapsiperheen toiselle aikuiselle ei nyt budjetoitu joukkoliikenteen kuukausilippua. Vuoden 2015 viitebudjettiin verrattuna liikkumisen kustannukset ovat alentuneet lapsiperheissä. Heillä liikkumisen kustannuksia ovat alentaneet sekä autoa käyttävän aikuisen joukkoliikennelipun poisto että alentuneet autoilun kustannukset. Autoilun laskennalliset kilometrikulut ovat alentuneet lähinnä autoveron muutoksen aiheuttaman autojen hinnan alenemisen sekä todennäköisesti myös autojen pienemmän polttoaineen kulutuksen vuoksi. Autoilun kuukausikulut olivat vuoden 2013 viitebudjetissa 562 euroa. Muilla viitebudjettitalouksilla liikkumisen kulut ovat kasvaneet kustannusten nousun vuoksi.

Kulutustutkimukseen verrattuna viitebudjettitalouksien liikkumisen kustannukset ovat vaatimattomat (noin 20-30 \%) lukuun ottamatta lapsiperheitä, joilla kustannukset ovat yli 80 prosenttia kulutustutkimuksen lapsiperheiden keskimääräisistä kustannuksista. Myös neljän alimman tuloviidenneksen keskikulutukset ovat lähellä kaikkien vastaavien talouksien keskiarvoja. On kuitenkin muistettava, että viitebudjetin kahden huoltajan lapsiperheissä on 4-5 henkilöä, kun kulutustutkimuksen kahden huoltajan talouksissa on keskimäärin alle kaksi lasta. Muilla talouksilla suuret erot johtuvat todennäköisesti ennen kaikkea siitä, että useimmissa talouksissa on auto, mutta viitebudjetin talouksista vain kahden huoltajan lapsiperheissä. 


\section{VIITEBUDJETTIEN YHTEENVETO JA VERTAILUJA}

\subsection{VIITEBUDJETIT ERILAISILLE KOTITALOUKSILLE}

Tässäluvussa esitetään yhteenveto viitebudjettitalouksien kuluista. Viitebudjetteihin on koottu kulut tuotteista ja palveluista, joita kuluttajat pitävät tarpeellisina tai välttämättöminä, jotta eläminen ja arki tämän päivän yhteiskunnassa sujuvat. Lisäksi tarvitaan mahdollisuus ylläpitää terveyttäja osallistua sosiaaliseen ja yhteiskunnalliseen toimintaan (ks. Borgeraas 1987; luku 2 tässä raportissa). Viitebudjettitalouksia eli esimerkkitalouksia, joille on laskettu kohtuullisen minimin mukainen budjetti, on yhteensä 13. Niiden kuvaukset on esitetty luvussa 3 ja kunkin hyödykeryhmän yksityiskohtaiset tarkastelut löytyvät luvusta 4. Liitteessä 1 on yksityiskohtainen hyödykeluettelo viitebudjettiin sisältyvistä tavaroista ja palveluista. Luettelossa on myös yli vuoden kestävien tuotteiden arvioitu käyttöikä. Kestäville tavaroille on laskettu vuosittaisen kulumisen kustannus, jolloin hankintahinta on jaettu arvioidulla käyttöiällä (ks. luku 3). Tavarat ovat hypermarkettien keskihintaisia tavaroita, eikä alennuksia tai käytettyjä tavaroita ole huomioitu (ks. periaatteet luku 3). Hinnat on koottu pääosin vuoden 2018 keväällä. Liitteessä 2 on listattu viitebudjetteihin sisältyvät vaatteet ja liitteessä 3 on esitetty ruokalistat, joihin kotona syötyjen ruokien kustannukset perustuvat.

Viitebudjettitalouksien välttämättömien kulujen yhteissumma kuukaudessa vaihtelee pääkaupunkiseudulla yksin asuvien alle 45-vuotiaiden lähes 1 380 eurosta kahden vanhemman ja kolmen teinin perheen noin 4250 euroon (Helsingissä noin $1380-4310$ e/kk). Muualla Suomessa vaihtelu on vastaavasti noin 1 130-3 770 euroa kuukaudessa. (Taulukot 15 ja 16.) Oletuksena on silloin, että myös muun Suomen paikkakunnilla on sujuva julkinen liikenne. Mikäli joukkoliikennettä ei ole ja tarvitaan oman auto, se kasvattaa talouden budjettia noin 395 euroa kuukaudessa ${ }^{22}$. Esimerkiksi mikäli työikäinen yksin asuva muualla Suomessa tarvitsee auton, hänen kulunsa olisivat 115-150 euroa suuremmat kuin autottoman Helsingissä.

Kuten aiemmin, myös tässä viitebudjetissa asuminen ja ruoka ovat selvästi suurimmat menoerät. Yksin asuvien ruokamenot vaihtelevat yli 65-vuotiaan naisen noin 180 eurosta alle 45-vuotiaan miehen yli 290 euroon kuukaudessa. Kahden huoltajan esimerkkitalouksien ruokakulut vaihtelevat pikkulapsiperheen

22 auton kulut - aikuisen joukkoliikennelippu: $450 \mathrm{e} / \mathrm{kk}-55 \mathrm{e} / \mathrm{kk}=395 \mathrm{e} / \mathrm{kk}$ 
710 eurosta kolmen teinikäisen perheen noin 1115 euroon kuukaudessa (ks. luku 4.1). Esimerkkitalouksien asumiskulut puolestaan vaihtelevat Helsingissä yksiöiden 738 eurosta neliöiden 1490 euroon kuukaudessa ja muualla Suomessa vuokrat ovat vastaavasti noin 490-950 euroa kuukaudessa (ks. luku 4.7).

Alle 45-vuotiaiden yksin asuvien miesten ruokakulut ovat suuremmat kuin saman ikäisten naisten, koska miesten energian tarve on suurempi. Alle 45-vuotiailla naisilla taas vaatteiden, lääkkeiden ja henkilökohtaisen hygienian menot ovat suuremmat kuin miehillä, mikä tasoittaa miesten ja naisten viitebudjettikulut lähes yhtä suuriksi. Yli 65-vuotiailla yksin asuvilla miehillä suuremmat menot ruuassa korottavat heidän budjettinsa suuremmaksi (12 e/kk) kuin saman ikäisten naisten, vaikka naisilla vaatetuksen ja henkilökohtaisen hygienian menot ovat hieman suuremmat. Iäkkäillä yksin asuvilla asumisen ja terveyden hoidon menot ovat suuremmat kuin nuoremmilla ja siten kokonaismenot suuremmat. Iäkkäiden pienemmät ruuan, vaatetuksen ja henkilökohtaisen hygienian menot hieman tasoittavat eroa nuorempiin yksin asuviin verrattuna. Kaksilapsissa kahden vanhemman perheissä suurimmat erot eri-ikäisten lasten välille muodostuvat erityisesti ruuasta, liikkumisesta, tietoliikenteestä ja harrastuksista. Pikkulapsiperheessä, jossa on alle kouluikäiset lapset, on pienempi asunto kuin muilla neljän hengen perheillä ja se vaikuttaa eniten muita lapsiperheitä pienempään budjettiin. 
Taulukko 15. Viitebudjetit yksin asuville ja pareille vuonna 2018, e/kk/kotitalous.

\begin{tabular}{|c|c|c|c|c|c|c|c|}
\hline $\begin{array}{l}\text { Esimerkkitaloudet } \\
\text { Hyödykeryhmät, e/kk }\end{array}$ & $\begin{array}{l}\text { Yksin asuva } \\
\text { M alle } 45 \mathrm{v}\end{array}$ & $\begin{array}{l}\text { Yksin asuva } \\
\mathrm{N} \text { alle } 45 \mathrm{v}\end{array}$ & $\begin{array}{l}\text { Yksin asuva } \\
\text { M yli } 65 \mathrm{v}\end{array}$ & $\begin{array}{l}\text { Yksin asuva } \\
\mathrm{N} \text { yli } 65 \mathrm{v}\end{array}$ & $\begin{array}{l}\text { Pari, 50v+ } \\
\text { työssä }\end{array}$ & $\begin{array}{l}\text { Pari, työssä } \\
\text { \& eläkk. }\end{array}$ & $\begin{array}{l}\text { Pari, yli } 65 \mathrm{v} \\
\text { eläkkeellä }\end{array}$ \\
\hline Ruoka & 294 & 261 & 205 & 179 & 554 & 458 & 383 \\
\hline $\begin{array}{l}\text { Tietoliikenne ja viihde- } \\
\text { elektroniikka }\end{array}$ & 65 & 65 & 65 & 65 & 95 & 95 & 95 \\
\hline $\begin{array}{l}\text { Kodinkoneet, huonekalut ja } \\
\text { muut kestohyödykkeet }\end{array}$ & 37 & 37 & 38 & 38 & 49 & 49 & 49 \\
\hline Kodin lyhytkestoiset tarvikkeet & 7 & 7 & 8 & 8 & 11 & 11 & 11 \\
\hline Vaatteet, kengät, laukut yms. & 47 & 59 & 42 & 49 & 106 & 101 & 90 \\
\hline Henkilökohtainen hygienia & 28 & 34 & 24 & 31 & 55 & 53 & 52 \\
\hline $\begin{array}{l}\text { Tervydenhoidon tarvikkeet, } \\
\text { lääkkeet, lääkärikäynnit }\end{array}$ & 23 & 32 & 43 & 43 & 53 & 68 & 83 \\
\hline Vapaa-aika ja harrastukset & 48 & 48 & 50 & 50 & 90 & 88 & 89 \\
\hline Sähkö ja vakuutukset & 34 & 34 & 36 & 36 & 53 & 53 & 53 \\
\hline $\begin{array}{l}\text { Yhteensä, ilman } \\
\text { ruokaa,liikkumista ja vuokraa }\end{array}$ & 289 & 318 & 307 & 320 & 510 & 517 & 523 \\
\hline $\begin{array}{l}\text { Yheensä, ilman litkkumista ja } \\
\text { vuokraa }\end{array}$ & 583 & 579 & 512 & 499 & 1064 & 975 & 906 \\
\hline \multicolumn{8}{|l|}{ Liikkuminen } \\
\hline Polkupyörä ja varusteet ym. & 8 & 8 & 8 & 8 & 16 & 16 & 16 \\
\hline Auto & 0 & 0 & 0 & 0 & 0 & 0 & 0 \\
\hline $\begin{array}{l}\text { Alueen sisäinen julkinen } \\
\text { liikenne }\end{array}$ & 55 & 55 & 44 & 44 & 110 & 99 & 88 \\
\hline $\begin{array}{l}\text { Seutulippu (käsittäen myös } \\
\text { naapurikuntia) }\end{array}$ & 106 & 106 & - & - & 212 & 150 & - \\
\hline Asuminen (vuokra) & \multicolumn{2}{|c|}{ yksiö (n. $32 \mathrm{~m} 2$ ) } & \multicolumn{2}{|c|}{ kaksio (n. $51 \mathrm{~m} 2$ ) } & \multicolumn{3}{|c|}{ kolmio (n. $73 \mathrm{~m} 2$ ) } \\
\hline Helsinki & 738 & 738 & 922 & 922 & 1176 & 1176 & 1176 \\
\hline Pääkaupunkiseutu (PKS) & 733 & 733 & 896 & 896 & 1128 & 1128 & 1128 \\
\hline Yli 100000 asukasta & 594 & 594 & 724 & 724 & 932 & 932 & 932 \\
\hline $\begin{array}{l}\text { Muu Suomi } \\
\text { (koko maa - PKS) }\end{array}$ & 487 & 487 & 605 & 605 & 740 & 740 & 740 \\
\hline $\begin{array}{l}\text { Koko maa, } \\
\text { vuokra-as. }\end{array}$ & 571 & 571 & 684 & 684 & 856 & 856 & 856 \\
\hline \multicolumn{8}{|l|}{$\begin{array}{l}\text { Yhteensä (alueen sisäinen } \\
\text { joukkolitkenne) }\end{array}$} \\
\hline Helsinki & 1384 & 1380 & 1486 & 1473 & 2366 & 2266 & 2186 \\
\hline Pääkaupinkiseutu & 1379 & 1375 & 1460 & 1447 & 2318 & 2218 & 2137 \\
\hline Yli 100000 asukasta & 1240 & 1235 & 1288 & 1275 & 2123 & 2023 & 1942 \\
\hline Muu Suomi & 1133 & 1129 & 1169 & 1156 & 1930 & 1830 & 1749 \\
\hline Koko maa keskim. & 1217 & 1213 & 1248 & 1236 & 2046 & 1947 & 1866 \\
\hline
\end{tabular}


Taulukko 16. Viitebudjetit lapsiperheille vuonna 2018, e/kk/kotitalous.

\begin{tabular}{|c|c|c|c|c|c|c|}
\hline $\begin{array}{l}\text { Esimerkkitaloudet } \\
\text { Hyödykeryhmät, e/kk }\end{array}$ & $\begin{array}{l}\text { YH-perhe, yksi } \\
\text { leikki-ikäinen }\end{array}$ & $\begin{array}{c}\text { YH-perhe, kaksi } \\
\text { teini-ikäistä }\end{array}$ & $\begin{array}{l}\text { Pikkulapsiperhe, } \\
\text { kaksi lasta }\end{array}$ & $\begin{array}{l}\text { Lapsiperhe, } \\
\text { kaksi lasta }\end{array}$ & $\begin{array}{l}\text { Teiniperhe, } \\
\text { kaksi lasta }\end{array}$ & $\begin{array}{l}\text { Teini-perhe, } \\
\text { kolme lasta }\end{array}$ \\
\hline Ruoka & 341 & 619 & 710 & 766 & 942 & 1115 \\
\hline $\begin{array}{l}\text { Tietoliikenne ja viihde- } \\
\text { elektroniikka }\end{array}$ & 65 & 104 & 95 & 110 & 142 & 157 \\
\hline $\begin{array}{l}\text { Kodinkoneet, } \\
\text { huonekalut ja muut } \\
\text { kestohyödykkeet }\end{array}$ & 47 & 61 & 65 & 67 & 68 & 76 \\
\hline Kodin lyhytkestoiset tarvikkeet & 11 & 15 & 17 & 18 & 19 & 21 \\
\hline Vaatteet, kengät, laukut yms. & 121 & 196 & 237 & 238 & 241 & 307 \\
\hline Henkilökohtainen hygienia & 42 & 68 & 73 & 73 & 97 & 106 \\
\hline $\begin{array}{l}\text { Tervydenhoidon tarvikkeet, } \\
\text { lääkkeet, lääkärikäynnit }\end{array}$ & 35 & 43 & 62 & 62 & 70 & 74 \\
\hline Vapaa-aika ja harrastukset & 58 & 176 & 95 & 130 & 166 & 220 \\
\hline Sähkö ja vakuutukset & 46 & 55 & 55 & 108 & 108 & 116 \\
\hline $\begin{array}{l}\text { Yhteensä, ilman ruokaa, } \\
\text { liikkumista ja vuokraa }\end{array}$ & 426 & 717 & 699 & 806 & 910 & 1078 \\
\hline $\begin{array}{l}\text { Yhteensä, ilman litkkumista } \\
\text { ja vuokraa }\end{array}$ & 767 & 1336 & 1409 & 1572 & 1852 & 2193 \\
\hline \multicolumn{7}{|l|}{ Liikkuminen } \\
\hline Polkupyörä ja varusteet ym. & 15 & 25 & 27 & 31 & 33 & 41 \\
\hline Auto & 0 & 0 & 450 & 450 & 450 & 450 \\
\hline $\begin{array}{l}\text { Alueen sisäinen julkinen } \\
\text { liikenne }\end{array}$ & 55 & 110 & 55 & 83 & 110 & 138 \\
\hline $\begin{array}{l}\text { Seutulippu (käsittäen myös } \\
\text { naapurikuntia) }\end{array}$ & 106 & 212 & 106 & 159 & 212 & 265 \\
\hline Asuminen (vuokra) & kaksio & \multicolumn{2}{|c|}{ kolmio (n. $73 \mathrm{~m} 2)$} & \multicolumn{3}{|c|}{$4 h+k \quad(n .92 m 2)$} \\
\hline Helsinki & 922 & 1176 & 1176 & 1490 & 1490 & 1490 \\
\hline Pääkaupunkiseutu (PKS) & 896 & 1128 & 1128 & 1426 & 1426 & 1426 \\
\hline Yli 100000 asukasta & 724 & 932 & 932 & 1180 & 1180 & 1180 \\
\hline $\begin{array}{l}\text { Muu Suomi } \\
\text { (koko maa - PKS) }\end{array}$ & 605 & 740 & 740 & 952 & 952 & 952 \\
\hline $\begin{array}{l}\text { Koko maa, } \\
\text { vuokra-as. }\end{array}$ & 684 & 856 & 856 & 1106 & 1106 & 1106 \\
\hline \multicolumn{7}{|l|}{$\begin{array}{l}\text { Yhteensä (alueen sisäinen } \\
\text { joukkolitkenne) }\end{array}$} \\
\hline Helsinki & 1759 & 2647 & 3116 & 3625 & 3934 & 4312 \\
\hline Pääkaupinkiseutu & 1733 & 2599 & 3068 & 3561 & 3870 & 4247 \\
\hline Yli 100000 asukasta & 1561 & 2404 & 2873 & 3316 & 3625 & 4002 \\
\hline Muu Suomi & 1442 & 2211 & 2680 & 3087 & 3396 & 3773 \\
\hline Koko maa keskim. & 1521 & 2327 & 2796 & 3241 & 3550 & 3927 \\
\hline
\end{tabular}

Lapsiperheiden kuvaukset: YH-perhe yksi leikki-ikäinen: äiti ja 3-v. tyttö; YH-perhe kaksi teini-ikäistä: äiti, 10-v. poika ja 13-v. tyttö; Pikkulapsiperhe: äiti, isä, poika 2 v ja tyttö 6 v; Lapsiperhe: äiti, isä, 4-v. poika ja 10-v. tyttö; Teiniperhe kaksi lasta: äiti, isä, teini-ikäistä: 14-v. tyttö ja 16-v. poika; Teiniperhe kolme lasta: äiti, isä, 10-v. poika, 15-v. poika ja 17-v. tyttö (ks. luku 3.) 


\section{Viitebudjettien käyttäminen}

Erilaisten esimerkkiperheiden viitebudjetteihin on koottu välttämättömät, tavanomaiset kulut. Ne koostuvat monista pienistä kuluista, joiden suuruutta kokonaisuutena saattaa olla vaikea arvioida. Näitä kululaskelmia kaikki voivat hyödyntää arvioidessaan omaa välttämätöntä kulutustaan. Viitebudjettien hyödykelistat (Liite 1) paljastavat, mitä tavaroita ja palveluja budjettiin on sisällytetty. Niitä voi hyödyntää arvioimalla, miten omat tarpeet ja käytännöt vastaavat viitebudjetin hyödykevalikoimaa. Luvussa 5.2 on laskettu eri-ikäisten lasten kulut, joiden avulla esimerkkiperheitä voi muunnella suuremmiksi tai pienemmiksi lisäämällä tai vähentämällä yksittäisen lapsen kulut.

Mikäli yksilöllä tai kotitaloudella on säännöllisiä erityismenoja, jotka eivät ole mukana viitebudjettilaskelmissa, ne voi lisätä omaan budjettiin juuri sen suuruisena kuin ne ovat. Tällaisia menoja ovat esimerkiksi päivähoitomaksut tai kroonisen sairauden lääkekulut, jotka ovat eri tilanteissa erisuuruisia, eikä niitä ole kaikilla talouksilla. Lukiokuluista on arviolaskelma (luku 5.2), jonka mukaan lukiokuluja tulee viitebudjetissa huomioitujen kulujen lisäksi noin 65 euroa kuukaudessa kutakin lukiolaista kohden.

Asuminen on viitebudjeteissa laskettu erillisenä osana eri asuinalueiden ja erikokoisten asuntojen keskivuokrien perusteella. Tämän keskikulun voi korvata omilla todellisilla asumiskuluilla. Niin ikään liikkumisen tarve saattaa poiketa esimerkkilaskelmien alueen sisäisenliikenteen kulujen mukaisesta. Auto on budjetoitu viitebudjetissa vain kahden huoltajan lapsiperheille. Se saattaa olla välttämätön myös muilla, jolloin aikuisen sisäisen liikenteen lipun voi vaihtaa auton kuluihin. Vaihdon seurauksena liikkumisen kulut kasvavat 395 euroa kuukaudessa, mikäli käytössä oleva auto on keskihintainen ja sillä ajetaan noin $15000 \mathrm{~km}$ vuodessa (ks. luku 4.8). Tällöin myös vapaa-ajan vierailujen ja matkojen matkalippukulut jäävät pois, mikäli matkat tehdään omalla autolla. Vastaavasti lapsiperheet voivat muokata kululaskelmaa omia kulujaan vastaavaksi, jos autoa ei tarvita.

\subsection{ERI-IKÄISTEN LASTEN KUSTANNUKSET}

Julkisissa keskusteluissa ja monissa muissa yhteyksissä pohditaan, kuinka suuret kustannukset yksi lapsi aiheuttaa. Viitebudjettien pohjalta voidaan tuottaa eriikäisille lapsille kohtuullisen minimin mukainen karkea arvio lasten aiheuttamista kuluista eri-ikäisinä. Mukaan on otettu vain kohtuullisen selkeät ja konkreettiset kulut lasta kohden viitebudjetin pohjalta ikäryhmittäin 2-17-vuotiaille sekä kouluikäisillä erikseen tytöille ja pojille (Taulukko 17). Tällöin ei ole arvioitu esimerkiksi isojen perheiden tarvetta suurempaan asuntoon tai autoon ja sen aiheuttamia kustannuksia. Viitebudjettilaskelmissa ei myöskään ole huomioitu sitä, että useamman 
lapsen taloudessa isomman sisaruksen tavaroista osa voidaan hyödyntāä nuoremmalla. Tavaroiden perimiseen vaikuttaa merkittävästi muun muassa lasten sukupuoli ja ikäero. Lasten tavaroissa voidaan saada säästöä myös myymällä tarpeettomaksi käyneet tavarat ja toisaalta hankkimalla tavaroita käytettynä edullisemmin.

Taulukko 17. Eri-ikäisten lasten kustannukset, e/kk.

\begin{tabular}{|lccccc|}
\hline Menoryhmä/ ikä ja sukupuoli & $\begin{array}{c}\mathbf{2 - 6} \\
\text { vuotta }\end{array}$ & $\begin{array}{c}\mathbf{7 - 1 2} \mathbf{~ v .} \\
\text { tytöt }\end{array}$ & $\begin{array}{c}\mathbf{7 - 1 2} \text { v. } \\
\text { pojat }\end{array}$ & $\begin{array}{c}\mathbf{1 3 - 1 7} \text { v. } \\
\text { tytöt }\end{array}$ & $\begin{array}{c}\mathbf{1 3}-\mathbf{1 7} \text { v. } \\
\text { pojat }\end{array}$ \\
\hline Ruoka & 106 & 183 & 209 & 221 & 257 \\
\hline Vaatteet, kengät ja laukut yms. & 62 & 69 & 68 & 65 & 70 \\
\hline Tietoliikenne & 0 & 71 & 71 & 80 & 80 \\
\hline Liikkuminen & 10 & 36 & 36 & 36 & 36 \\
\hline Hygienia yms. & 10 & 10 & 10 & 22 & 17 \\
\hline $\begin{array}{l}\text { Terveys } \\
\text { Harrastukset, vapaa-aika }\end{array}$ & 7 & 8 & 8 & 8 & 8 \\
\hline $\begin{array}{l}\text { Henkilökohtaiset huonekalut, } \\
\text { ym. kodin irtain }\end{array}$ & 8 & 54 & 54 & 54 & 54 \\
\hline Yhteensä, $€$ /kk & $\mathbf{2 1 7}$ & $\mathbf{4 4 0}$ & $\mathbf{4 6 5}$ & $\mathbf{4 9 4}$ & $\mathbf{5 3 0}$ \\
\hline
\end{tabular}

Iän myötä kulut kasvavat alle kouluikäisten lähes 220 eurosta kuukaudessa teinikäisten tyttöjen noin lähes 500 euroon ja poikien 530 euroon kuukaudessa. Ruuan osuus lasten kulutuksesta on lähes puolet.

Ruokaa lukuun ottamatta useimmat poikien ja tyttöjen kulut ovat lähes yhtä suuret (Taulukko 17). Alakouluikäisten kulut ovat lähes kaksinkertaiset leikki-ikäisiin verrattuna. Kouluikäisillä lisääntyvät tietoliikennekulut, koska heille on laskettu mukaan oma, edullinen kännykkä. Heille on budjetoitu myös oma työpöytä ja työtuoli koulutehtävien tekemistä varten. Teinikäisten budjettia kasvattavat edellisten lisäksi oma kannettava tietokone, joka tarvitaan viimeistään lukiossa tai ammattikoulussa. Viitebudjetissa se on budjetoitu yläkouluikäisestä (13 v) lähtien. Teinikäisillä tytöillä kasvavat myös hygieniakulut, koska he tarvitsevat esimerkiksi kuukautissuojat. Pojille taas on budjetoitu miesten puku, mikä lisää vaatekuluja.

Viitebudjetissa suurin esimerkkiperhe on viisihenkinen, jossa on kolme teiniikäistä lasta (10-v ja 15-v pojat, 17-v tyttö). Yhtä lasta suuremman perheen menot kasvaisivat lapsen iästä ja sukupuolesta riippuen noin 220-530 euroa kuukaudessa. Mikäli Pääkaupunkiseudulla asuvassa perheessä olisi vielä kaksi lasta lisāä ja he olisivat 13-vuotias tyttö ja 8-vuotias poika, niin 7-henkisen perheen kokonaisbudjetti olisi lähes 5220 euroa kuukaudessa (lasten yksilöllisten kulujen lisäys yht. 991 e/kk). Mikäli talouden neljäs ja viides lapsi olisivat alle kouluikäisiä, perheen 
kokonaisbudjetti olisi yhteensä lähes 4700 euroa kuukaudessa (lasten yksilöllisten kulujen lisäys yht. 434 e/kk). On kuitenkin huomattava, että mahdollisen suuremman asunnon tai auton aiheuttamaa lisäkustannusta ei tällöin ole otettu huomioon. Myöskään mahdollista säästöä tavaroiden tai vaatteiden siirtämisestä nuoremmille lapsille ei esimerkeissä ole huomioitu.

Vastaavasti kaksilapsisen talouden budjetin voi muuttaa yhden lapsen taloudeksi vähentämällä toisen lapsen kustannukset.

\section{Toisen asteen opiskelijoiden oppimateriaalikustannukset}

Lukioissa- ja ammattioppilaitoksissa opiskelu on maksutonta ja opiskelijoille tarjotaan maksuton ateria koulupäivinä. Kotitaloudet kustantavat kuitenkin itse tarvittavat oppikirjat, muuta oppimateriaalia ja tietoteknisiä laitteita, joita opiskelu edellyttää. Käytännössä kaikki yläkoulun, lukion ja ammattioppilaitoksen opiskelijat tarvitsevat oman kannettavan tietokoneen, jonka hankintaan ainoastaan harvat oppilaitokset tai kunnat osallistuvat. Kuntien välillä on suuria eroja esimerkiksi kotitalouksien maksamien oppimateriaalien kuluissa ja mahdollisuuksissa lainata tietokonetta koulusta ${ }^{23}$. Lukiolaisten liitto on laskenut lukion kolmen vuoden kustannuksiksi yli 2600 euroa eli lähes 900 euroa vuodessa ${ }^{24}$ (Taulukko 18). Ongelmia pienituloisille talouksille lisää myös se, että suuri osa kunkin lukukauden kuluista lankeaa maksettavaksi lukukauden alussa.

Taulukko 18. Esimerkkilukiolaisen kustannukset, e/3 vuotta.

\begin{tabular}{lcc}
$\begin{array}{l}\text { Kirjat yhteensä } \\
\text { (digioppikirjat hieman edullisempia) }\end{array}$ & 1986 e \\
Muita välineitä ja materiaaleja, yht. & $\mathbf{5 1 0 ~ e ~}$ \\
\hline Tietokone & 300 e & 50 e \\
\hline Laskin & 10 e & \\
\hline Kuvaamataidon materiaalit & 50 e & \\
\hline Kirjoitusvälineet, vihkot yms. & 100 e & $\mathbf{1 6 8}$ e \\
\hline Liikuntavälineet & & \\
\hline Ylioppilastutkintomaksut (5 kirjoitettavaa ainetta) yht. & 28 e & 140 e \\
\hline Perusmaksu (14 e/kpl) & & $\mathbf{2 6 6 4 ~ e ~}$
\end{tabular}

(Laskelma: Suomen lukiolaisten liitto 2016.)

23 Yle selvitti: Näin erilaiset lähtökohdat lapset saavat koulutielle asuinpaikan perusteella - katso koulukoneesta, miten kuntasi menestyi. 15.5.2018 https://yle.fi/uutiset/3-10181489

24 Helsingin Sanomat 2016: (http://www.hs.fi/kaupunki/art-2000002920697.html) 
Opiskelijat pyrkivät säästämään muun muassa hankkimalla käytettyjä oppikirjojaja myymällä käyttämänsä kirjat eteenpäin. Ryhmäkeskusteluissa tuli kuitenkin esiin, että monissa kouluissa on siirrytty sähköisiin oppikirjoihin, jotka ovat lähes yhtä kalliita kuin painetut. Sähköisten oppikirjojen kierrättäminen ei ole mahdollista. Ylioppilaskirjoitusten muuttuessa kokonaan sähköisiksi vuoteen 2019 mennessä lukio-opiskelijan on käytännössä välttämätöntä saada käyttöönsä kannettava tietokone. Osalla keskusteluissa mukana olleista vanhemmista oli kokemuksia ammattikoululaisten kustannuksista, joita he pitivät lähes yhtä suurina kuin lukiokustannuksia. Heidän mukaansa myös monissa ammattiopinnoissa oma tietokone on välttämätön. (vrt. Aamulehti 2016²5.)

Viitebudjetissa on huomioitu osa lukiolaisten kuluista. Viitebudjettiin sisältyy esimerkiksi tietokone ja liikuntavälineitä, mutta suurin osa em. laskelman lukiokustannuksista (775 e/v) jää viitebudjetin ulkopuolelle. Muiden lukiokustannusten lisääminen taulukon 18 laskeman mukaisena kasvattaisi viitebudjettia keskimäärin noin 65 euroa kuukaudessa kutakin perheen lukiolaista kohden.

\subsection{MUUTOKSET VERRATTUNA VUODEN 2013 VIITEBUDJETTIIN}

Viitebudjetin hyödykeryhmittely ja viitebudjettitaloudet on pidetty päivityksessä ennallaan ja uusina viitebudjettitalouksina lisättiin yhden ja kahden huoltajan pikkulapsiperheet ja kaksi lapsetonta paria, joista toisessa on kaksi noin 50-vuotiasta työssäkäyvää ja toisessa molemmat puolisot ovat yli 65-vuotiaita eläkeläisiä. Hyödykeryhmien sisällä on joitakin muutoksia ryhmäkeskusteluiden ja asiantuntijakommenttien perusteella. Useimmissa tuoteryhmissä hinnankorotukset ovat olleet melko pienet, kun verrataan vuosien 2015 ja 2018 hintoja. Suurimmat kustannusmuutokset muutokset ovat ruoassa ja autoilussa sekä asumisessa ja terveysmenoissa.

Kotitalouskohtaiset ruokamenot ovat laskeneet yksin asuvien talouksissa noin 15 euroa ja lapsiperheissä 70-96 euroa kuukaudessa. Ruoan hinta on laskenut vuodesta 2015. Hinnat kerättiin alkuvuodesta 2018, joten sen jälkeinen hintojen nousu $^{26}$ ei näy laskelmissa. Kodin ulkopuolella ateriointia on myös harvemmin kuin aiemmin..

25 Aamulehti 2016: https://www.aamulehti.fi/kotimaa/laskelma-lukiolaisen-koulutus-maksaa-7-700ammattikoululaisen-11-500-euroa-vuodessa-23976481/

26 Onko halpuutuksen aika ohi? Ruoan hinta nopeassa nousussa. https://yle.fi/uutiset/3-10314999; Ruuan hinnan lasku on ohi, ennustaa PTT. https://www.talouselama.fi/uutiset/ruuan-hinnan-laskuon-ohi-ennustaa-ptt-nousukausi-panee-pisteen-3-vuoden-halpenemiselle/109d6dd6-8a75-3290-b755$93 \mathrm{~d} 8 \mathrm{gfef} 3 \mathrm{~d} 34$ 
Autoilun kustannukset puolestaan ovat laskeneet aiemmasta viitebudjetista verotusmuutosten vaikutuksesta yli 100 euroa kuukaudessa. Joukkoliikenteen kulut puolestaan ovat hieman kasvaneet. Pyöräilyn kustannuksiin lisättiin myös pyörän huolto. Edellä mainittujen muutosten seurauksena autottomien kotitalouksien liikkumisen kustannukset hieman kasvoivat ja autollisten lapsiperheiden puolestaan laskivat.

Asumisen kustannukset viitebudjetissa ovat laskeneet, koska nyt vuokrien laskentaa on tarkennettu ja se perustuu alueellisiin asuntotyyppien (yksiöt, kaksiot, kolmiot ja neliöt) keskikokoihin ja alueellisiin asuntotyypittäisiin keskineliövuokriin. Edellisissä viitebudjeteissa kullekin asuntotyypille oli määritelty valtakunnallinen keskikoko ja alueellinen keskineliövuokra. Uuden laskentatavan seurauksena yksiöiden koko on nyt pienempi ja isojen asuntojen neliövuokrat puolestaan alemmat (ks. luku 4.7).

Lääkekustannukset kasvoivat, kun ehkäisypillerit ja reseptilääkekustannukset otettiin mukaan. Reseptilääkekulut hinnoiteltiin Kelan tilaston mukaisina omavastuun mediaanikuluina iän ja sukupuolen perusteella, mikä korotti erityisesti yli 65-vuotiaiden lääkekuluja (luku 4.5).

Aiemmassa viitebudjetissa harrastuksiin ja vapaa-aikaan varattua rahamäärää keskustelijat pitivät liian pienenä. Nyt lasten harrastuksiin varattu rahamäärä kaksinkertaistettiin, jotta se mahdollistaa harrastamisen. Myös muita vapaa-ajan kuluja korotettiin. Korotusten seurauksena kaikilla viitebudjettitalouksilla vapaaajan menot kasvoivat selvästi. Kahden huoltajan lapsiperheillä vapaa-ajan kokonaiskustannukset kasvoivat vähemmän kuin autottomalla yksinhuoltajataloudella. Ero johtuu siitä, että nyt laskelmassa lapsiperheet käyttävät omaa autoaan lomamatkoillaan juna-/bussilippujen sijaan, mikä alensi lapsiperheiden lomamatkojen kustannuksia aiempaan verrattuna (luku 4.6).

Keskustelijat ehdottivat hyödykelistalle lisää kotitaloustarvikkeita ja vaatteita, joten niitä täydennettiin. Koska käytössä on enemmän tuotteita, niiden kuluminen vähenee, minkä vuoksi käyttöikää pidennettiin. Vaatetuskulut ovat hieman kasvaneet aiemmasta. Sen sijaan pitkäkestoisen kodin irtaimiston kulut ovat pysyneet lähes ennallaan. Kertakäyttöisten kotitaloustarvikkeiden kulut ovat hieman laskeneet muun muassa pesuaineiden edullisempien hintojen vuoksi. Kuvaan 1 on koottu esimerkkejä kulutusmuutoksista viitebudjettitalouksissa. 


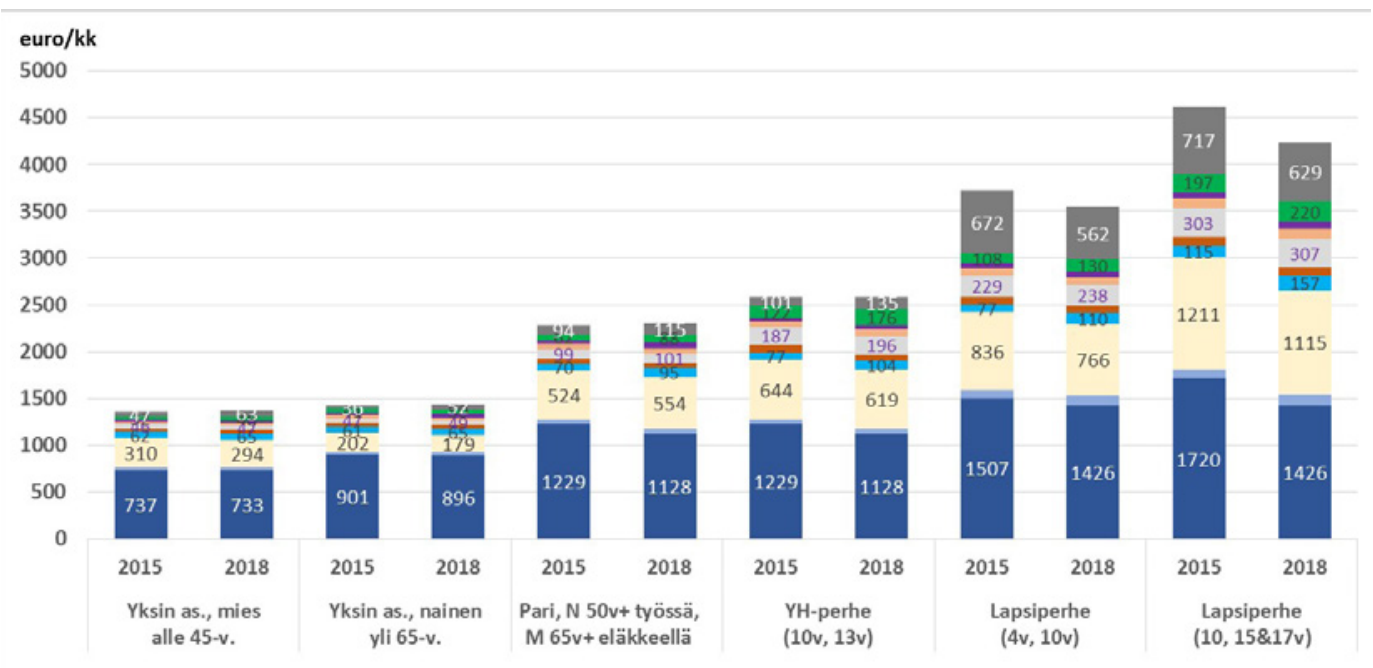

Kuva 1. Vertailu eräiden viitebudjettitalouksien kuluista vuosina 2015 ja 2018, e/kk.

Helsingin ja pääkaupunkiseudun vuokrahinnoilla useimpien viitebudjettitalouksien kokonaiskustannukset ovat pysyneet lähes ennallaan ja lapsiperheillä ne ovat hieman laskeneet. Pääkaupunkiseudun ulkopuolella viitebudjettitalouksien kokonaiskustannukset ovat laskeneet kaikilla hieman enemmän kuin pääkaupunkiseudulla. Ruoan ja asumisen kustannukset ovat laskeneet ja lapsiperheillä lisäksi autoilun kulut. Muut viitebudjetin kulut yhteensä ovat pääsääntöisesti kasvaneet.

\subsection{VIITEBUDJETIT VERRATTUNA KOTITALOUKSIEN KESKIKULUTUKSEEN}

Viitebudjettien kokonaiskulutus on hyvin maltillista verrattuna vuoden 2016 kulutustutkimukseen eli vastaavien kotitalouksien keskimääräiseen kulutukseen. Viitebudjetin mukainen kulutus pääkaupunkiseudun(PKS) kotitalouksissajää myös alhaisemmaksi kuin vastaavien kotitalouksien neljän alimman tuloviidenneksen ${ }^{27}$ yhteinen keskikulutus (Kuva 2). Kulutustutkimuksen kaikkien kotitalouksien keskikulutuksen ero muun Suomen viitebudjettitalouksiin on vielä suurempi.

27 Neljänalimmantuloviidenneksen(kvintiilit1-4)kulutusmenojenkeskiarvossakotitalouksistasuurituloisimman viidenneksen (ylin kvintiili) kulutusmenot eivät ole mukana. 


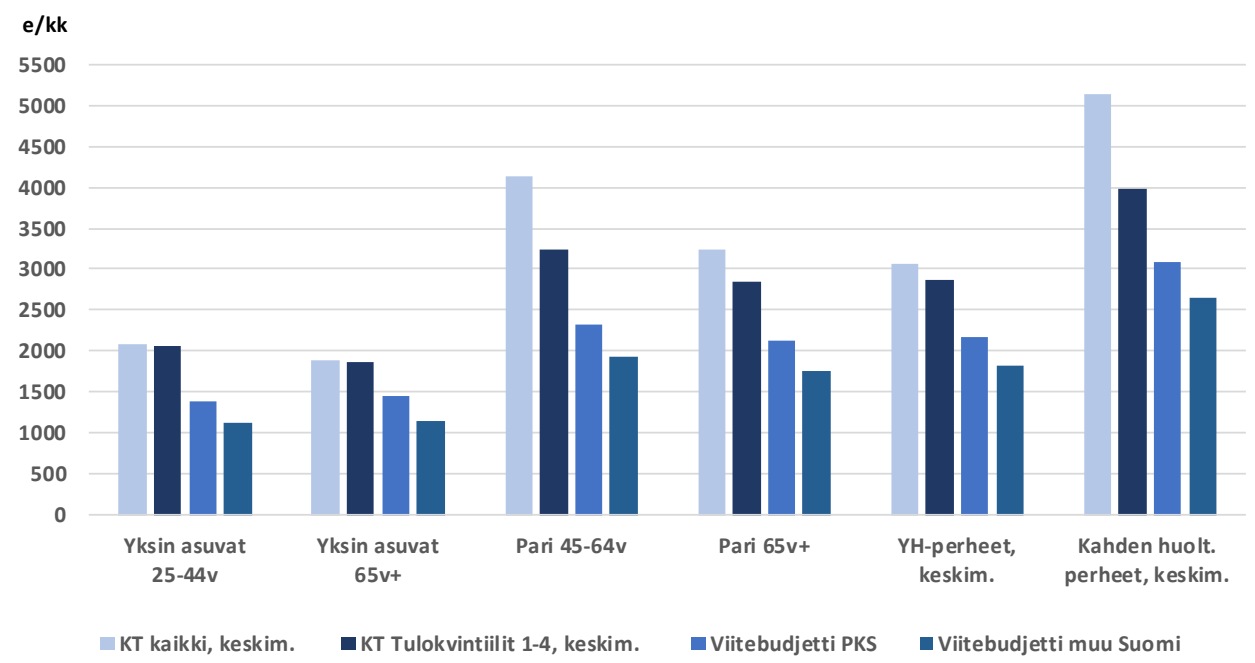

Kuva 2. Viitebudjettien ja vuoden 2016 kulutustutkimuksen kokonaismenot eri perhetyypeissä, e/kk.

KT = kulutustutkimus 2016, KT Tulokvintiilit 1-4 = kulutusmenojen keskiarvo ilman suurituloisinta viidennestä. (Omat laskelmat).

Yksin asuvilla viitebudjetin alle 45-vuotiaiden kokonaiskulut kattoivat kulutustutkimuksen 25-44-vuotiaiden mukaisesta kokonaiskulutuksesta yli 65 prosenttiaja vastaavasti yli 65-vuotiailla viitebudjetti kattoi siitäyli 75 prosenttia. Parien kokonaiskulutuksesta viitebudjetitkattoivat kaikkien parien keskiarvoon verrattuna noin $55-70$ prosenttia ja neljään alimpaan tuloviidennekseen verrattuna runsaat 70 prosenttia. Viitebudjetin kahden lapsen perheiden keskiarvo vastasi noin 60 prosenttia kaikkien kahden vanhemman talouksien keskikulutuksesta ja alle 80 prosenttia neljän alimman tuloviidenneksen lapsiperheiden keskikulutuksesta. Kulutustutkimuksen lapsiperheissä oli keskimäärin alle kaksi lasta $(1,8)$, mikä edelleen korostaa eroa. Yhden huoltajan perheiden viitebudjettien keskiarvon kattavuus verrattuna kulutustutkimuksen kaikkiin vastaaviin talouksiin oli 70 prosenttia ja neljän alimman tuloviidenneksen keskikulutukseen lähes 80 prosenttia. Kulututkimuksen yhden huoltajan talouksissa oli keskimäärin 1,3 lasta. Suuremman kattavuuden taustalla on myös todennäköisesti se, että yksinhuoltajaperheet joutuvat arjessa tinkimään hankinnoistaan enemmän kuin kahden huoltajan lapsiperheet. Viitebudjetissa yksinhuoltajaperheen lapsille on budjetoitu samat hyödykkeet kuin kahdenhuoltajan perheissä, mutta viitebudjetin yksinhuoltajaperheissä ei ollut autoa.

Asumisen ja ruoan osuus kokonaisbudjetista korostuu viitebudjeteissa selvästi verrattuna vuoden 2016 kulutustutkimukseen, koska viitebudjetit sisältävät vain välttämättömän kulutuksen. Ruoan osuus viitebudjeteissa on pienimmillään yksin asuvilla yli 65-vuotiailla naisilla (12 \%) ja suurimmillaan esimerkkitaloudessa, jossa on vanhemmat ja kolme teini-ikäistä lasta (26\%). Asumisen osuus puolestaan on 
viitebudjetissa suurin kaksioissa asuvilla yli 65-vuotiailla (yli 6o \%). Pareilla sekä nuoremmilla yksin asuvilla asuminen vie noin puolet viitebudjetin kuluista ja lapsiperheillä runsaan kolmasosan. Liikennemenojen osuus kulutuksesta on ainoastaan kahden huoltajan lapsiperheillä samaa luokkaa kuin kulutustutkimuksessa (noin $15 \%$ ), koska viitebudjeteissa vain heillä on auto. Muilla liikenteen osuus viitebudjetista jää noin viiteen prosenttiin. Edellä mainitut kulurakenteet koskevat pääkaupunkiseudulla asuvia viitebudjettitalouksia.

Helsingissä viitebudjettitalouksien asumiskulujen osuus on vielä suurempi kuin pääkaupunkiseudulla ja muiden kulutusryhmien vastaavasti hieman pienempiä. Muualla Suomessa (pääkaupunkiseudun ulkopuolella) yksiöissä yksin asuvilla asumisen osuus on alle 40 prosenttia ja kaksioissa asuvilla 44 prosenttia. Asumisen osuus viitebudjettikuluista on suurempi kuin ruoan myös muualla Suomessa, lukuun ottamatta kolmen teini-ikäisen perhettä, jossa ruoan osuus (26 \%) on siellä suurempi kuin asumiskulujen (22 \%).

Kulutustutkimuksessa vuonna 2016 asumisen keskimääräinen osuus oli 31 prosenttia kulutusmenoista, ruoan osuus noin 15 prosenttia (kotiin ostetut elintarvikkeet 12 prosenttia ja ulkona syöminen 3 prosenttia) eli pienemmät kuin useimmilla viitebudjettitalouksilla. Kulutustutkimuksen ulkona syömisen osuus sisältää sekä henkilöstöravintoloissa että vapaa-ajalla erilaissa ravintoloissa syömisen. Nuorilla yksin asuvilla ulkona syömisen osuus kulutusmenoista on suurin (6 \%) ja iäkkäillä yksin asuvilla ja pareilla pienin (1 \%). Ylimmät tuloluokat käyttävät enemmän erilaisia ravintolapalveluita kuin kaikki taloudet keskimäärin. ${ }^{28}$ Viitebudjetissa ulkona syömisen osuus on hyvin vaatimaton ja sisältyy ruokaan eli samaan ryhmään kuin kotiin ostetut elintarvikkeet. Ruokakulut viitebudjeteissa ovat useimmilla talouksilla lähes yhtä suuret kuin vastaavilla kotitalouksilla keskimäärin, kun otetaan huomioon sekä kotiin ostetut elintarvikkeet että ulkona syöminen.

Useimmissa muissa hyödykeryhmissä viitebudjetit jäävät alle keskikulutuksen. Suurimmat erot keskikulutukseen ovat kodin lyhytkestoisissa tarvikkeissa ja vapaa-ajassa, joissa viitebudjetti kattaa useimmilla talouksilla alle 40 prosenttia keskikulutuksesta. Kodinkoneiden, kodin muiden kestohyödykkeiden, terveydenhoidon ja liikkumisen keskikulutuksesta viitebudjetit kattavat noin puolet. Myös tietoliikenne ja viihde-elektroniikka jäävät lähes kaikilla talouksilla selvästi alle keskikulutuksen. Henkilökohtainen hygienia on viitebudjeteissa lähes keskikulutuksen tasoa. Vaatetus on ainoana hieman keskikulutusta korkeampi. Erityisesti kalliita ulkovaatteita hankitaan alennusmyynneistä ja joissain tilanteissa myös käytettynä, mutta näitä vaihtoehtoja ei ole viitebudjetissa huomioitu, kuten ei myöskään vaatelahjoja tai kierrätystä nuoremmille sisaruksille.

28 Omat laskelmat Tilastokeskuksen vuoden 2016 kulutustutkimuksen aineistolla 
Kulutustutkimuksen pienituloisimman viidenneksen kulutusrakenne on selvästi samankaltaisempi viitebudjettien kanssa kuin edellä verratut kaikkien kotitalouksien keskikulutus. Kulutustutkimuksen pienituloisimman viidenneksen asumismenot muodostavat 40 prosenttia, ruoka lähes 14 prosenttia ja liikkuminen noin 10 prosenttia kulutusmenoista (Tilastokeskus 2018b). Pienituloisten on todettu tinkivän päivittäisistä menoistaan esimerkiksi asumisen tai auton vuoksi, joista ei haluta luopua (Kajantie 2018). Ruoka ja vaatteet ovat tyypillisiä menoja, joissa näkyviä säästöjä saa helposti, kun rahasta on puutetta. Samalla joudutaan ehkä tinkimään ruoan terveellisyydestä ja tuoretuotteista sekä ostamaan vaatteita mahdollisimman edullisesti ja harventamaan niiden uusimista. 


\section{POHDINTA JA KEHITTÄMISTARPEET}

Olemme päivittäneet kohtuullisen minimin viitebudjettien sisällöt samalla kuluttajalähtöisellä menetelmällä kuin vuosina 2010 ja 2013. Tämä oli toinen kerta, kun käytimme sitä yhtä laajasti kuin vuonna 2010. Olemme samalla menetelmällä pitäneet yhteensä 35 ryhmäkeskustelua, joissa on ollut 104 kuluttajaa. Viitebudjettien kulutustaso on niukka, mutta olettamus on, että talouksissa on ennestään pitkäkestoisia tavaroita, joita ei heti tarvitse uusia. Osallistuminen on mukana miltei jokaisessa hyödykeryhmässä: voi ruokailla yhdessä muiden kanssa, siistit vaatteet mahdollistavat osallistumisen erilaisiin tilaisuuksiin, siistiin kotiin voi kutsua vieraita halutessaan tai vapaa-ajan harrastukset tukevat omaa hyvinvointiaja voi tavata muita ihmisiä. Toiminnot ovat konkreettisia. Ne on muunnettu tarvittaviksi hyödykkeiksi ja hyödykekoreiksi, jotka hinnoittelun jälkeen muodostavat viitebudjetin.

Menetelmän kannalta tärkeimmät eli kuluttajat rekrytoitiin ulkopuolisen rekrytointiyrityksen kautta eri puolelta Suomea. Tämä osoittautui hyväksi toimintatavaksi ja keskusteluryhmiin saatiin erilaisten kotitalouksien edustajia keskustelemaan viitebudjettien sisällöistä. Kuluttajien sitouttaminen ei ole ollut ongelma tälläkään kerralla, sillä ryhmien jäsenten aito kiinnostus ryhmän toisia jäseniä kohtaan ja tutkimusaiheeseen sekä pieni palkkio edistävät sitä (Lehtinen ym 2013). Välttämätön kulutus ja arkielämän tilanteet ovat osallistujille tuttuja ja heitä yhdistävä teema, jolloin niistä on helppo keskustella muiden kanssa.

Kuluttajia osallistui hyödykekorien päivitykseen riittävästi. Rekrytoimme 40 henkilöä, vaikka muutama henkilö jäi pois, eivät ryhmien koot jääneet liian pieniksi ja erilaisissa elinvaiheissa olevia kotitalouksia oli jokaisessa ryhmässä. Ryhmät, joissa oli erilaisia kotitalouksia, keskustelivat vilkkaasti, toivat esiin vaihtoehtoisia arjen toimintatapoja ja perusteluja hyödykkeiden välttämättömyydelle. He löysivät yhteisymmärryksen sisältöihin keskustelemalla. Lapsiperheistä koostuvan ryhmän ei tarvinnut hakea samalla tavalla yhteisymmärrystä, koska he tunnistavat lapsiperheen arjen kokemukset helposti ja ovat enemmän toistensa kaltaisia kuin muut kotitaloustyypit. Viitebudjeteissa on eri-ikäisiä lapsia, joten on ollut sisällön päivityksen kannalta hyvä, että eri-ikäisten lasten vanhemmat ovat keskustelemassa yhdessä. Muissa ryhmissä olevat lapsiperheet toivat esiin samanlaisia asioita kuin yksinomaan lapsiperheistä koostuva ryhmä. Tällä kertaa esille nousivat erityisesti lasten harrastukset ja koulumateriaalit. Käytyjen keskustelujen pohjalta vahvistuu se, että vain määrättyä kotitaloustyyppiä edustavat taloudet ovat hyvin saman mielisiä ja vaihtoehtojen pohtiminen sellaisissa ryhmissä voi olla väkinäistä (Bradshaw ym. 2008; myös Deeming 2010). 
Järjestimme kaksi ryhmäkeskustelukertaa kevään 2017 aikana, joiden välillä osallistujilla oli noin kaksi kuukautta aikaa kotitehtävän tekemiseen. Emme järjestäneet kolmatta keskustelua, vaan osallistujilla oli mahdollisuus kommentoida sähköisesti hyödykekoriluonnoksia. Vuonna 2010 kolmannen keskustelun anti oli vähäinen, minkä vuoksi jätimme sen pois. Kaksi keskustelua on kuitenkin minimi, jos on lisäksi kotitehtäviä, muutoin keskustelukertoja tarvitaan enemmän kuin kaksi. Käytimme samaa keskustelurunkoa kuin vuosina 2010 ja 2013. Ensimmäinen keskustelu oli johdatus pohtimaan välttämättömyyksiä viitebudjettien tavoitteiden mukaisesti, ja siinä päästiin jo yhteisymmärrykseen esimerkiksi ruokaan liittyvistä periaatteista. Toisella tapaamiskerralla, kun kotitehtävää oli pohdittu usein oman perheen kanssa, löytyi näkemyksiä ja kokemuksia muihin hyödykeryhmiin. Lyhytkestoisten kodintarvikkeiden välttämättömiä lukumääriä koettiin vaikeaksi arvioida, mutta keskustelemalla toisten kanssa kuluttajat pystyivät tarkentamaan arvioitaan. Tässä tutkijoita auttoivat kuluttajien täyttämät hyödykeluettelot sekä kulutustilastot. Toinen keskustelukerta on menetelmän ja prosessin kannalta tärkein, koska kuluttajilla on ollut aikaa sisäistää ja pohtia välttämätöntä kulutusta tässä yhteiskunnassa, ja tuoda omia näkemyksiään ja kokemuksiaan keskusteluun. Toisessa keskustelussa konsensus muodostuu kuluttajien oman kokemuksen, toisten kuuntelun ja keskustelun kautta, jolloin vältytään yksinomaan mielipiteiden käsittelyltä.

Asiantuntijoiden rooli on pienempi kuin kuluttajilla, mutta tärkeä tuki tutkijoille laadintaprosessissa. On hyvä olla erilaisen taustan omaavia asiantuntijoita arvioimassa hyödykekoriluonnoksia. Olemme saaneet asiantuntijoilta tarkennuksia ja neuvoja joidenkin hyödykeryhmien käsittelyyn. Asiantuntijat eivät ole muokanneet koriluonnoksien sisältöjä, ennemminkin ehdottaneet lisäämään tai vähentämään lukumäärï tai kestoikiä.

Jotta viitebudjetit olisivat käyttökelpoisia ja ajanmukaisia, niitä on päivitettävä. Viitebudjettien kehittäminen ja päivittäminen ovat hidasta työtä. Kuluttajien arjessa tapahtuu muutoksia, joiden pitää näkyä budjeteissa. Hintapäivitykset voidaan tehdä hyvin Tilastokeskuksen kuluttajahintaindeksillä vuosittain, jolloin hintojen keräystä ei tarvita. Sisällön päivitys olisi tehtävä neljän tai viiden vuoden välein, jotta sisällöt pysyvät ajantasaisina. Jos päivityksiä olisi useammin kuin nyt on ollut, keskusteluihin osallistuvien kuluttajien lukumäärää voisi vähentää tai keskittyä erityisesti määrätyn kuluttajaryhmän kulutukseen. Edelleen, jos budjetit pystytään päivittämään useammin, menetelmän kehittäminen edistyisi ja joitakin nykyisiä olettamuksia (vuokra-asuminen/omistusasuminen, terveys/sairaus) voitaisiin ratkaista. Samoin budjetteihin voisi ottaa laajemman kirjon esimerkkiperheitä, jolloin esimerkiksi monilapsiset perheet ja niiden erityispiirteet saataisiin 
mukaan (asunnon ja auton koko, kierrätysmahdollisuus vaatteissa ja tarvikkeissa). Tavaroita ostetaan usein alennusmyynneistä ja tarjoushinnoin, miten ne voitaisiin hinnoitella viitebudjettiin.

Uusia tapoja kuluttaa tulee jatkuvasti, eikä välttämättömiä tarpeita arvioivissa viitebudjeteissa ole tarkoitus sisällyttää niitä suoraan budjetteihin. Tässä päivityksessä keskusteltiin esimerkiksi autojen tai työkalujen yhteiskäyttömahdollisuudesta, mutta käytännöt eivät ole vielä vakiintuneita ja kaikille mahdollisia, että ne voisi huomioida viitebudjeteissa. Viitebudjetti on niukka, ja siten ympäristöä keskimääräisesti vähemmän kuluttava. Ilmastonmuutoksen pienentämisen haasteet ja seuraukset tulevat muokkaamaan viitebudjettien sisältöjä. Päätetäänkö tulevaisuudessa kestävien kulutuskorien sisällöt kuluttajien ja asiantuntijoiden kesken nykyistä tiiviimmällä yhteistyöllä (ks. Gough 2017)? Kohtuullinen kulutus ja kestävä kehitys ovat teemoja, joita ei voida jättää huomioimatta. Entä millaiset ovat SOTE:n tai liikennekaaren vaikutukset suomalaisille kuluttajille?

Joissakin viitebudjeteissa on varattu rahaa laitettavaksi säästöön kulutuksesta. Päivitetyissä viitebudjeteissa ei sellaista rahaa ole varattu, eikä siitä keskusteltu ryhmissä. Pitkäaikaisten tavaroiden laskennallinen poisto on säästöä, jonka sivuun laittamisella voi varautua uuden hankintaan. Se merkitsee usean vuoden säästämistä ja pitkäjänteisyyttä. Viitebudjeteissa ei ole huomioitu erikseen välillisiä veroja, joiden merkitys korostuu erityisesti monilapsisten perheiden taloudessa. Myös välillisten verojen vaikutusta erikokoisten talouksien kulutuksessa pitää harkita tarkasteltavaksi seuraavassa päivityksessä. Eräs viitebudjettien ulkoasuun ja tekniseen puoleen liittyvä asia on, käytetäänkö jatkossa samanlaista hyödykeryhmäjakoa vai esimerkiksi jakoa kiinteisiin ja muuttuviin kuluihin. Käytäviin keskusteluihin sillä ei olisi merkitystä. Viitebudjettien digitalisointi helpottaisi päivitystyötä sekä viitebudjettien hyödyntäjien työtä.

Viitebudjetit antavat konkreettista tietoa siitä, mitä eläminen maksaa. Hyödykekoripohjaiset laskelmat yhdistävät kotitalouden tarpeet, toiminnan, kulutuksen ja hyödykemarkkinat. Budjetit tarjoavat viitetason, johon yksittäisen kotitalouden kulutusta voi verrata (Aatola ja Viinisalo 1995). Toteutunut-kulutus toimii myös suorempana toimeentulon kuvaajana kuin esimerkiksi tulot (Hircsh 2010) On muistettava, että viitebudjetit heijastelevat todellisuutta ja auttavat päätöksentekoa, mutta ne eivät korvaa päätöksentekoa (Saunders ja Bedford 2017). Viitebudjetteja voi hyödyntää monipuolisesti ja ne tuovat esiin vaihtoehtoisen tavan tarkastella kuluttajien tarpeita ja kulutustapoja tässä ajassa. 


\section{LÄHTEET}

Aalto, K. (2018) Elintarvikkeiden kulutus kotitalouksissa vuonna 2016 ja muutokset vuosista 2012, 2006 ja 1998. Helsinki: Helsingin yliopisto, Valtiotieteellisen tiedekunnan julkaisuja 2018:80. Saatavilla: http://hdl. handle.net/10138/235324. Luettu 30.8.2018.

Aalto, K. (2014) Kuluttajien halukkuus ja toimintatavat tekstiilien kierrätyksessä. Tutkimuksia ja selvityksiä 12/2014. Helsinki: Kuluttajatutkimuskeskus. Saatavilla: https://helda.helsinki.fi/handle/10138/153031Luettu 19.3.2018.

Aalto, K. \& Heiskanen, E. (2011) Kestävä ruokalautanen joukkoruokailun kestävän kehityksen edistäjänä. Helsinki: Kuluttajatutkimuskeskus, työselosteita ja esitelmiä 130 .

Aalto, K. \& Peltoniemi, A. (2014) Elintarvikkeiden kulutusmuutokset kotitalouksissa 2006-2012. Helsinki: Kuluttajatutkimuskeskus, tutkimuksia ja selvityksiä $10 / 2014$.

Aatola, L. \& Viinisalo, M. (1998) Mitä eläminen maksaa? Tarvebudjetti vähimmäisturvan arvioinnin tukena. Laskentamenetelmän ja aineiston kuvaus. Helsinki: Kuluttajatutkimuskeskus, työselosteita ja esitelmiä 46.

Adato (2013) Kotitalouksien sähkön käyttö 2011. Tutkimusraportti 2013. Adato Energia Oy. Saatavilla: https://www.vattenfall.fi/ globalassets/energianeuvonta/kodin-sahkonkulutus/kotitalouksien sahkonkaytto 2011 tutkimusraportti.pdf Luettu 14.5.2018.

Borgeraas, E. (1987) Et standardsbudjett for forbruksutgifter. Rapport nr. 101. Lysaker: Statens institutt for forbruksforskning SIFO.

Bradshaw, J., Middleton, S., Davis, A., Oldfield, N., Smith, N., Cusworth, L. \& Williams, J. (2008) A minimum income standard for Britain. What people think? Joseph Rowntree Foundation and Loughborough University. Saatavilla:www.jrf.org.uk. Luettu 15.10.2018. 
CREDOC (2014) ONPES reference budgets. Study conducted at the request of the French National Observatory on Poverty and Social Exclusion (ONPES). Final report. CREDOC \& IRES. Saatavilla: http://www.onpes.gouv.fr/le-rapportde-l-onpes-2014-2015-485.html Luettu 14.5.2018.

Davis, A., Hirsch, D., Padley, M. \& Marshall, L. (2015) How much is enough? Reaching social consensus on minimum household needs. Centre for Research in Social Policy. Loughborough University. Saatavilla: http:// www.lboro.ac.uk/media/wwwlboroacuk/content/crsp/downloads/reports/ How\%20much\%20is\%20enough.pdf Luettu 21.5.2018.

Deeming, C. (2010) The Historical Development of Family Budget Standards in Britain, from the 17th century to the Present. Social Policy \& Administration 44(7), 765-788.

Doyal, L. \& Gough, I. (1991) A Theory of Human Need. Hong Kong: MacMillan Education Ltd.

Druckman, A., Hartfree, Y., Hirsch, D., \& Perren, K. (2011) Sustainable income standards: towards a greener minimum? Joseph Rowntree Foundation. December 2011 Saatavilla: https://www.jrf.org.uk/report/sustainableincome-standards-towards-greener-minimum Luettu 15.10.2018.

Druckman, A. \& Jacson, T. (2010) The bare necessities: How much household carbon do we really need? Ecological Economics, 69 (9), 1794-1804.

Evira (2014) Suomalaiset ravitsemussuositukset 2014. Valtion ravitsemusneuvottelukunta. Saatavilla: https://www.evira.fi/globalassets/ vrn/pdf/ravitsemussuositukset terveytta-ruoasta 2014 fi web v4.pdf. Luettu 17.4.2018.

FINE (2017) Kotivakuutusja tuotevakuutukset - Esimerkki pienen kodin irtaimiston vakuuttamisesta. Vakuutus- ja rahoitusneuvonta. FINE. Saatavilla: https:// www.fine.fi/media/julkaisut-2017/kotivakuutus-ja-tuotevakuutukset-2017. pdf Luettu 16.3.2018. 
Goedemé, T. Storms, B. Penne, T., Van den Bosch (2015) Pilot project for the development of a common methodology on reference budgets in Europe. The development of a methodology for comparable reference budgets in Europe - Final report of the pilot project. October 2015. European Commission. Directorate-General for Employment, Social Affairs and Inclusion. Applica. Universiteit Antwerpen.

Gough, I. (2017) Heat, Greed and Human Need. Climate Change, Capitalism and Sustainable Wellbeing. UK, Cheltenham: Edward Elgar Publishing Ltd.

Hirsch, D. (2010) Reference Budgets in Europe. Final European Conference on Reference Budgets, “Reference Budgets for Social Inclusion”, October 2009, Vienna, Austria.

HSL (2018) Liput ja hinnat. Lippujen hinnat 2018. Saatavilla: https://www.hsl. fi/sites/default/files/uploads/lippujen hinnat fi_2018 esite.pdf Luettu 15.5.2018.

Ilmarinen, K. \& Kauppinen, T. M. (2018) Pienituloisuus ennen ja jälkeen asumiskustannuksia - alueellinen näkökulma. Yhteiskuntapolitiikka 83 (2018):1. 73-83. Saatavilla: https://www.julkari.fi/bitstream/ handle/10024/136018/YP1801 Ilmarinen\%26Kauppinen.pdf?sequence=1. Luettu 30.8.2018.

Kajantie, M. (2018) Kun rahat ovat vähissä, päivittäiskulutuksesta tingitään muihin menoihin. Tieto\&Trendit. Asiantuntija-artikkelit ja ajankohtaisblogit. 29.8.2018. Saatavilla: http://www.tilastokeskus.fi/tietotrendit/artikkelit/2 018/?listing=simple. Luettu 30.8.2018.

Kaufman, P., MacDonald, J.M., Lutz, S.M. \& Smallwood, D. (1997) Do the Poor Pay More for Food? Item Selection and Price Differences Affect Low-Income Household Food Costs, No 34065, Agricultural Economics Reports, United States Department of Agriculture, Economic Research Service. Saatavilla: http://ageconsearch.umn.edu/record/34065/files/ae970759.pdf. Luettu 30.8.2018. 
Kauppinen T.M., Hannikainen-Ingman, K., Sallinen, S. \& Viitanen, V. (2015) Pienituloisten asuinolot. Helsinki: Terveyden ja hyvinvoinnin laitos, työpaperi 22/2015. Saatavilla: https://www.julkari.fi/bitstream/ handle/10024/129573/URN ISBN 978-952-302-541-7.pdf?sequence=1. Luettu 30.8.2018.

Kokko, S. \& Mehtälä, A. (toim.) (2016) Lasten ja nuorten liikuntakäyttäytyminen Suomessa. LIITU-tutkimuksen tuloksia 2016. Valtion liikuntaneuvoston julkaisuja 2016:4. Saatavilla: http://www.liikuntaneuvosto.fi/files/438/ LIITU 2016.pdf. Luettu 30.3.2018.

Konsumentverket (2018). Koll på pengarna. Tips och råd om din ekonomi. Saatavilla: https://www.konsumentverket.se/globalassets/publikationer/ privatekonomi/koll-pa-pengarna-2018-konsumentverket.pdf. Luettu 30.8.2018.

Lehtinen, A-R. \& Aalto, K. (2014) Viitebudjettien päivitys vuodelle 2013. Mitä eläminen maksaa? Helsinki: Kuluttajatutkimuskeskus, tutkimuksia ja selvityksiä 3/2014.

Lehtinen, A-R., Varjonen, J. \& Aalto, K. (2013) Konsensusmenetelmän ja kuluttajalähtöisyyden edut kohtuullisen kulutuksen määrittelyssä.Teoksessa: Olli Kangas, Mikko Niemelä, Anu Raijas (toim.) Takaisin perusteisiin: perusturvan rïttävyys kulutuksen näkökulmasta. pp. 82-101. Helsinki: Kela, teemakirja 2013 (12).

Lehtinen, A-R., Varjonen, J., Raijas A., Aalto K. \& Pakoma R. (2010) Mitä eläminen maksaa? Kohtuullisen minimin viitebudjetit. Helsinki: Kuluttajatutkimuskeskus, julkaisuja, 4/2010.

Lettenmeier, M., Hirvilammi, T., Laakso, S. Lähteenoja, S. \& Aalto, K. (2012) Material footprint of low-income households in Finland. Consequences for the sustainability debate. Sustainability 4: 1426-1447.

Lindblom, T. (2017) Does sugar sweeten the pill of low income? Inequalities in the consumption of various foods between Finnish income groups from 1985 to 2012. Research on Finnish Society. 10, 61-71. 
Moisio, P., Mukkila, S., Ilmakunnas, I., Mäkinen, L. \& Saikkonen, P. (2016) Perusturvan riittävyys ja köyhyys.. Helsinki: Terveydenja hyvinvoinninlaitos, tutkimuksesta tiiviisti 23/2016. Saatavilla: http://www.julkari.fi/bitstream/ handle/10024/131346/URN ISBN 978-952-302-743-5.pdf?sequence=1. Luettu 24.9.2018.

Morris J.N. \& Deeming, C. (2004) Minimum Incomes for Healthy Living (MIHL): next thrust in UK social policy? Policy \& Politics, 32:4, 441-54.

Morris J.N., Wilkonson, P., Dangour, A.D., Deeming, C. \& Fletcher, A. (2007) Defining a minimum income for healthy living (MIHL): older age, England. International Journal of Epidemiology, Volume 36:6, 1300-1307.

Mäkelä, J. (2002) Syömisen rakenne ja kulttuurinen vaihtelu. Helsinki: Kuluttajatutkimuskeskus.

Mäkinen, L. (2017) Viitebudjetti köyhyyden mittarina - muuttuuko köyhyyden kuva? Yhteiskuntapolitiikka 82 (2), 153-164.

Nussbaum, M.C. (2011) Creating capabilities. The human Development Approach. Cambridge, Massachusetts and London, England: The Belknap Press of Harvard University Press.

Nurmela, J. (2018) Suomalaisten kulutus on samankaltaistunut. Tieto\&Trendit. Asiantuntija-artikkelit ja ajankohtaisblogit. 14.3.2018. Saatavilla: http:// www.tilastokeskus.fi/tietotrendit/artikkelit/2018/?listing=simple_Luettu 30.8.2018.

Nurmela, J. \& Parikka, T. (2018) Mobiilikuluttajan kukkarosta yhä isoin potti välttämättömyyksiin. Tieto\&Trendit. Asiantuntija-artikkelit ja ajankohtaisblogit. 28.8.2018. Saatavilla: http://www.tilastokeskus.fi/ tietotrendit/artikkelit/2018/?listing=simple. Luettu 30.8.2018.

Pankkiasiat (2014). Vakuutusten vertailu ja hintatekijät. Saatavilla: https:// pankkiasiat.fi/vakuutusten-vertailu-ja-hintatekijat (julkaistu 24.9.2014) Luettu 15.3.2018

Penne, T., Cussó Parcerisas, I., Mäkinen, L., Storms, B. \& Goedemé, T. (2016) Can refrence budgets be used as powerty line? Improve Working Papers 16/5. Saatavilla: http://improve-research.eu/?page id=37. Luettu 28.9.2018. 
Petnets (2015). Petnets-hankkeen loppuraportti. Saatavilla: http://blogs.helsinki. fi/pet-nets/files/2013/08/PETNETS-Julkinen-loppuraportti-FINAL-2015. pdf. Luettu 15.3.2018.

Raulio, S. Tapanainen,H. Nelimarkka, K.,Kuusiapalo, H. \& Virtanen, S. (2018) Kuudes- ja kahdeksasluokkalaisten ruoankäyttö. Koulujakelujärjestelmän alkukartoitus. Helsinki: Terveyden-ja hyvinvoinninlaitos, työpaperi 25/2018. Saatavilla: http://www.julkari.fi/bitstream/handle/10024/136807/URN ISBN 978-952-343-150-8.pdf?sequence=1\&isAllowed=y) Luettu 24.9.2018.

Rowntree, B.S. (1901) Poverty: A Study of Town Life. London: Macmillan.

Ruokatieto (2009) Suomalaisen ruokakulttuurin ulottuvuuksia. Finfood-Suomen ruoktieto ry.

Sen, A. (1995) Inequality re-examined. Oxford: Clarendon Press

Saunders, P. \& Bedford, M. (2017) New minimum healthy living budget standards for low-paid and unemployed Australians. Sydney: Social Policy Research Centre, UNSW, SPRC Report 11/17. Saatavilla: http://unsworks.unsw. edu.au/fapi/datastream/unsworks:46140/binc76de784-a739-416b-93616ebb285882ea?view=true Luettu 14.9.2017.

SIFO (2018) Reference Budget for Consumer Expenditures. Calculate your own budget. Saatavilla: http://www.hioa.no/eng/About-HiOA/Centre-forWelfare-and-Labour-Research/SIFO/Reference-Budget-for-ConsumerExpenditures/Kalkulator. Luettu 30.10.2018.

Silvasti,T. (2011) Ruoka-avun vakiinnuttaminen Suomessa. Tarpeen ja oikeutuksen jäljillä. Janus. 19(3)279-289.

STM (2018) Terveyskeskuksen enimmäismaksut 2018-2019. Sosiaali- ja terveysministeriö. Saatavilla: http://stm.fi/terveydenhuollon-maksut. Luettu 16.3.2018.

Storms, B. \&Van Den Bosch, K(2009) Mutual learning on referencebudgets: lessons learned. In: Handbook of Reference Budgets. On the design, construction and application of reference budgets. European Consumer Debt Network ECDN. 
Summarum media (2012) Tapaturmavakuutus - Mitä se käytännössä korvaa? Saatavilla: http://www.summarum.fi/tapaturmavakuutus/. Luettu 16.3.2018.

THL(2011) Perusturvan riittävyyden arviointiraportti (Työryhmäraportti). Helsinki: Terveyden ja hyvinvoinnin laitos (THL). Avauksia 4/2011. Luettu 13.9.2018.

THL (2015) Perusturvan riittävyyden arviointiraportti 2011-2015. Perusturvan riittävyyden II arviointiryhmä. Helsinki: Terveyden ja hyvinvoinnin laitos (THL). Työpaperi. 1/2015. Saatavilla: http://www.julkari.fi/ handle/10024/125703. Luettu 13.9.2018.

Tilastokeskus (2016) Autoilevien kotitalouksien osuus vakiintunut, lemmikkien omistaminen lisääntyy. Saatavilla: https://tilastokeskus.fi/til/ktutk/2016/ ktutk_2016_2016-11-03 tie_001_fi.html. Luettu 15.3.2018

Tilastokeskus (2017a)Asuntokunnatjaasuinolot2016.(1.102017)Saatavilla: $\underline{\text { ttps:// }}$ www.stat.fi/til/asas/2016/01/asas 201601 2017-10-11 kat 002 fi.html. Luettu 2.8.2018.

Tilastokeskus (2017b) Väestön tieto- ja viestintätekniikan käyttö 2017. Suomen virallinen tilasto (SVT). Helsinki: Tilastokeskus. Saatavilla: http://www.stat. fi/til/sutivi/2017/13/sutivi_2017 13 2017-11-22 tie 001 fi.html. Luettu 13.4.2018.

Tilastokeskus(2018a)Asuntojenvuokrat.Suomenvirallinentilasto(SVT).Asuminen. Saatavilla: http://tilastokeskus.fi/til/asvu/2018/o2/asvu 201802 2018o8-02 fi.pdf. Luettu 3.8.2018.

Tilastokeskus (2018b) Pienituloisimpien menoista yli puolet kuluu asumiseen ja ravintoon. SVT. Saatavilla: http://tilastokeskus.fi/til/ktutk/2016/ ktutk 2016 2018-03-13 tie 001 fi.html. Luettu 3.8.2018.

Tilastokeskus (2018c) Hyvinvointipalvelujen arvo kotitaloudelle on keskimäärin reilut 7 ooo euroa vuodessa. Kotitalouksien kulutus 2016. SVT. Saatavilla: http://tilastokeskus.fi/til/ktutk/2016/ktutk 2016 2018-10-02 fi.pdf. Luettu 8.10.2018. 
Verohallinto(2017)Verohallinnonpäätösvuodelta2018toimitettavassaverotuksessa noudatettavista luontoisetujen laskentaperusteista. Saatavilla: https:// www.vero.fi/syventavat-vero-ohjeet/paatokset/47380/verohallinnonp\% $\mathrm{C}_{3} \% \mathrm{~A}_{4} \% \mathrm{C}_{3} \% \mathrm{~A}_{4} \mathrm{t} \% \mathrm{C}_{3} \% \mathrm{~B} 6 \mathrm{~s}$-vuodelta-2018-toimitettavassaverotuksessa-noudatettavista-luontoisetujen-laskentaperusteista/. Luettu 25.6.2018.

Vikstedt,T., Raulio, S., Helakorpi, S., Jallinoja, P. \& Prättälä, R. (2012) Työaikainen ruokailu Suomessa 2008-2010. Ruokapalveluiden seurantaraportti 4. Helsinki: Terveyden ja hyvinvoinnin laitos. Raportti 23.

Warnaar M \& Luten A (eds.) (2009) Handbook of Reference Budgets. On the design, construction and application of reference budgets. European Consumer Debt Network ECDN. 


\section{LIITTEET}

Liite 1 Hyödykeluettelo 1/14

\begin{tabular}{|c|c|c|c|c|c|c|c|c|c|c|c|c|c|c|c|c|c|c|c|c|c|c|}
\hline 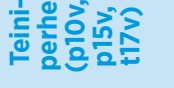 & in & & - & - & - & - & - & - & - & - & - & - & - & & -1 & - & $\nabla$ & L 1 & M & & $\forall$ & - \\
\hline 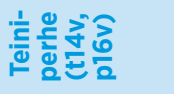 & $\theta$ & & - & - & - & - & - & - & - & - & - & - & - & & - & -1 & $\mathrm{~m}$ & $\begin{array}{lll} & 1\end{array}$ & $M$ & & $m$ & - \\
\hline 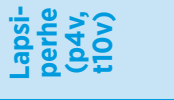 & $\theta$ & & - & - & - & - & - & - & - & - & - & - & - & & -1. & -0 & $\sim 1$ & $\mathrm{~m}$. & - & & $\stackrel{\sim}{\sim}$ & - \\
\hline 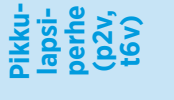 & 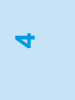 & & - & - & - & - & - & - & - & - & - & - & - & & - & - & - & $\sim$. & - & & $\sim$ & - \\
\hline 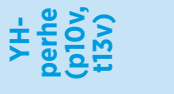 & m & & - & - & - & - & - & - & - & - & - & - & - & & - & -1 & $\mathrm{~m} 1$ & $\mathrm{~m}$ & $\sim$ & & $\sim$ & - \\
\hline 主突蛋 & $N$ & & - & - & - & - & - & - & - & - & - & - & - & & - & - & -1. & -1. & - & & - & - \\
\hline 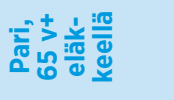 & $N$ & & - & - & - & - & - & - & - & - & - & - & - & & - & - & -1 & $\sim$ & - & & $\sim$ & - \\
\hline 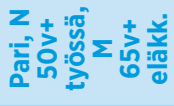 & $N$ & & - & - & - & - & - & - & - & - & - & - & - & & - & - & - & $\sim$ & - & & $\sim$ & - \\
\hline 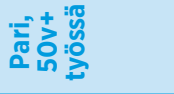 & $N$ & & - & - & - & - & - & - & - & - & - & - & - & & - & - & - & $\sim$ & - & & $\sim$ & - \\
\hline 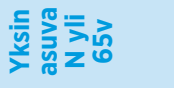 & - & & - & - & 0 & - & - & - & - & - & - & - & - & & - & - & -1. & -1. & - & & - & - \\
\hline 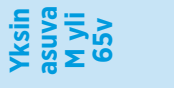 & - & & - & - & 0 & - & - & - & - & - & - & - & - & & - & - & - & -1. & - & & - & - \\
\hline 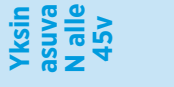 & - & & - & - & 0 & - & - & - & - & - & - & - & - & & - & - & - & -1. & - & & - & - \\
\hline \multirow[t]{3}{*}{ 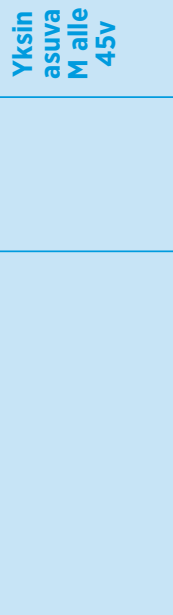 } & - & & - & - & 0 & - & - & - & - & - & - & - & - & & - & - & - & -1. & - & & - & - \\
\hline & & 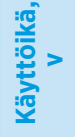 & $\simeq$ & $\simeq$ & 으 & $M$ & $M$ & $M$ & $\infty$ & $\infty$ & $\simeq$ & $\infty$ & $\stackrel{2}{20}$ & & $\sigma:$ & $\stackrel{\llcorner}{\llcorner}$ & $\simeq$ & $\nabla$ & เ & & 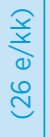 & $\begin{array}{l}\stackrel{\frac{\gamma}{y}}{\partial} \\
\stackrel{d}{d}\end{array}$ \\
\hline & 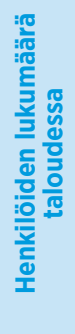 & 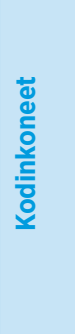 & 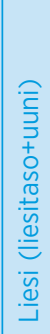 & 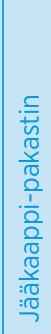 & 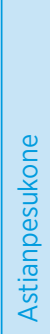 & 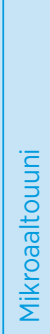 & 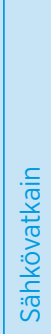 & 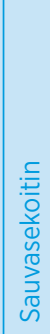 & 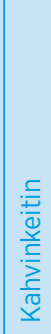 & 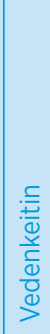 & 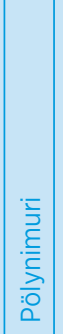 & 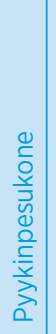 & 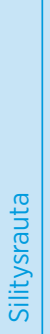 & 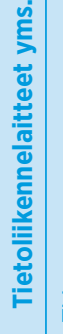 & $\geq$ & 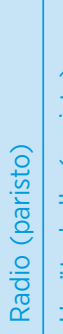 & 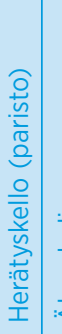 & 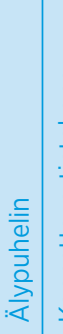 & 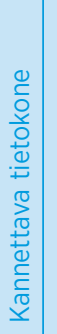 & 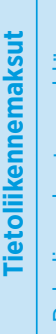 & 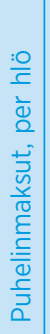 & 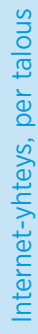 \\
\hline
\end{tabular}


Liite 1 Hyödykeluettelo $\quad 2 / 14$

\begin{tabular}{|c|c|c|c|c|c|c|c|c|c|c|c|c|c|c|c|}
\hline 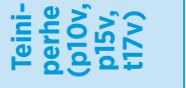 & $\Xi$ & $\Xi$ & $\infty$ & $\Xi$ & \pm & $\Xi$ & ○ & $\Xi$ & \pm & $\Xi$ & - & - & - & - & $\sim$ \\
\hline 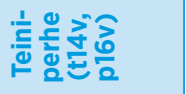 & $\simeq$ & $\simeq$ & $\infty$ & $\simeq$ & $\simeq$ & $\simeq$ & 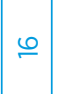 & $\simeq$ & $\simeq$ & $\simeq$ & - & - & - & - & $\sim$ \\
\hline 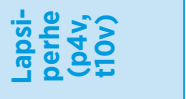 & $\simeq$ & $\simeq$ & 0 & $\simeq$ & $\simeq$ & $\simeq$ & 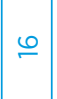 & $\simeq$ & $\simeq$ & $\simeq$ & - & - & - & - & $\sim$ \\
\hline 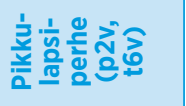 & $\simeq$ & $\simeq$ & 0 & $\simeq$ & $\simeq$ & $\simeq$ & 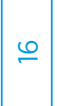 & $\simeq$ & $\simeq$ & $\simeq$ & - & - & - & - & $\sim$ \\
\hline 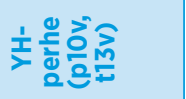 & 으 & 으 & 0 & 으 & 으 & 으 & $\simeq$ & 으 & 으 & 으 & - & - & - & - & $\sim$ \\
\hline 立紊誉 & $\infty$ & $\infty$ & 0 & $\infty$ & $\infty$ & $\infty$ & $\infty$ & $\infty$ & $\infty$ & $\infty$ & - & - & - & - & $\sim$ \\
\hline 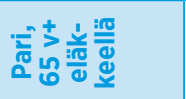 & $\infty$ & $\infty$ & 0 & $\infty$ & $\infty$ & $\infty$ & $\infty$ & $\infty$ & $\infty$ & $\infty$ & - & - & - & - & $N$ \\
\hline 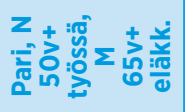 & $\infty$ & $\infty$ & 0 & $\infty$ & $\infty$ & $\infty$ & $\infty$ & $\infty$ & $\infty$ & $\infty$ & - & - & - & - & $\sim$ \\
\hline 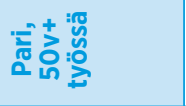 & $\infty$ & $\infty$ & 0 & $\infty$ & $\infty$ & $\infty$ & $\infty$ & $\infty$ & $\infty$ & $\infty$ & - & - & - & - & $\sim$ \\
\hline 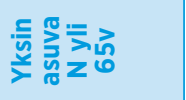 & 0 & 0 & 0 & 0 & 0 & 0 & 0 & 0 & 6 & 6 & - & - & - & - & $\sim$ \\
\hline 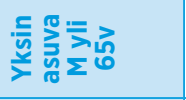 & 0 & 0 & 0 & 0 & 0 & 0 & 0 & 0 & 0 & 0 & - & - & - & - & $\sim$ \\
\hline 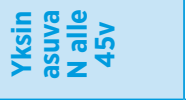 & 0 & 0 & 0 & 0 & 0 & 0 & 0 & 0 & 0 & 0 & - & - & - & - & $\sim$ \\
\hline 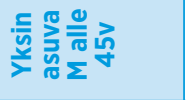 & 0 & 0 & 0 & 0 & 0 & 0 & 0 & 0 & 0 & 0 & - & - & - & - & $\sim$ \\
\hline 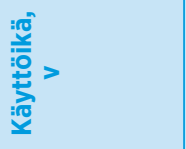 & $\stackrel{ }{2}$ & $\stackrel{\curvearrowleft}{\llcorner}$ & $\stackrel{\varrho}{\llcorner}$ & 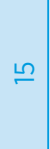 & $\stackrel{2}{\sim}$ & $\stackrel{\llcorner}{\llcorner}$ & ঃ & ㅇ & ㅇ & ㅇ & $\stackrel{\llcorner}{\simeq}$ & $\stackrel{2}{\sim}$ & $\stackrel{2}{\llcorner}$ & $\llcorner$ 으 & $\stackrel{\llcorner}{ }$ \\
\hline 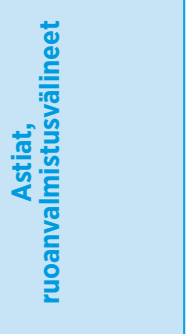 & $\frac{\bar{x}}{\frac{1}{2}}$ & 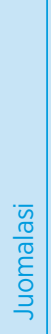 & 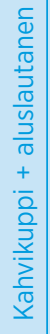 & 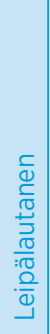 & 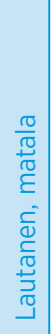 & 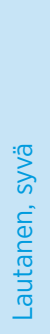 & 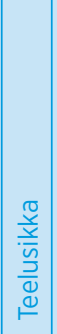 & 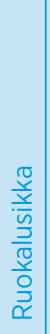 & $\begin{array}{l}\frac{\pi}{0} \\
\frac{3}{3} \\
\frac{3}{2} \\
\frac{\pi}{\pi} \\
\frac{\pi}{1}\end{array}$ & $\frac{\bar{y}}{9}$ & 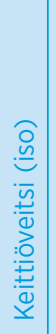 & 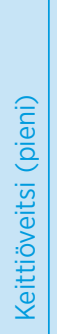 & 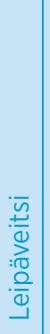 & 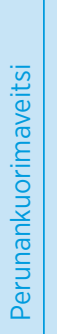 & 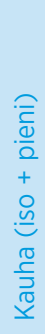 \\
\hline
\end{tabular}




\begin{tabular}{|c|c|c|c|c|c|c|c|c|c|c|c|c|c|c|c|c|c|c|c|c|c|c|c|c|}
\hline 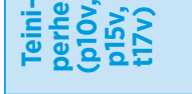 & - & - & - & $\sim$ & - & - & - & - & $\sim$ & - & $N$ & - & - & $M$ & - & - & - & - & - & $\stackrel{\stackrel{\sim}{\sim}}{ }$ & - & $\sim$ & $\sim$ & - \\
\hline 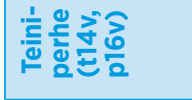 & - & - & - & $\sim$ & - & - & - & - & $\sim$ & - & $\sim$ & - & - & $M$ & - & - & - & - & - & $\stackrel{\stackrel{N}{\sim}}{ }$ & - & $\sim$ & $\sim$ & - \\
\hline 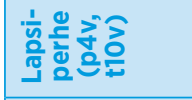 & - & - & - & $\sim$ & - & - & - & - & $\sim$ & - & $\sim$ & - & - & $M$ & - & - & - & - & - & $\stackrel{\llcorner}{\sim}$ & - & $\sim$ & $\sim$ & - \\
\hline 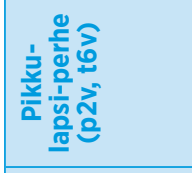 & - & - & - & $\sim$ & - & - & - & - & $\sim$ & - & $\sim$ & - & - & $M$ & - & - & - & - & - & $\stackrel{\llcorner}{\sim}$ & - & $\sim$ & $\sim$ & - \\
\hline 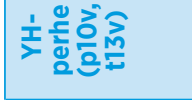 & - & - & - & $\sim$ & - & - & - & - & $\sim$ & - & $\sim$ & - & - & $M$ & - & - & - & - & - & $\stackrel{\stackrel{n}{N}}{ }$ & - & $\sim$ & $\sim$ & - \\
\hline 穸突旁 & - & - & - & $\sim$ & - & - & - & - & $\sim$ & - & - & - & - & $M$ & - & - & - & - & - & 尺 & - & $\sim$ & $\sim$ & - \\
\hline 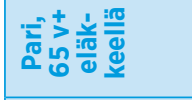 & - & - & - & $\sim$ & - & - & - & - & $\sim$ & - & - & - & - & $M$ & - & - & - & - & - & 尺 & - & $\sim$ & $\sim$ & - \\
\hline 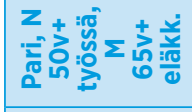 & - & - & - & $\sim$ & - & - & - & - & $\sim$ & - & - & - & - & $M$ & - & - & - & - & - & ㅇ & - & $\sim$ & $\sim$ & - \\
\hline 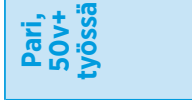 & - & - & - & $\sim$ & - & - & - & - & $\sim$ & - & - & - & - & $M$ & - & - & - & - & - & 尺 & - & $\sim$ & $\sim$ & - \\
\hline 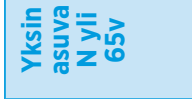 & - & - & - & $\sim$ & - & - & - & - & - & $\sim$ & - & - & - & $M$ & - & - & - & - & - & $\stackrel{\llcorner}{\llcorner}$ & - & $\sim$ & $\sim$ & - \\
\hline 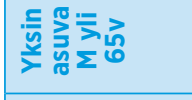 & - & - & - & $N$ & - & - & - & - & - & $\sim$ & - & - & - & $M$ & - & - & - & - & - & $\stackrel{\llcorner}{\sim}$ & - & $\sim$ & $\sim$ & - \\
\hline 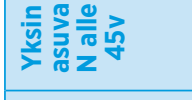 & - & - & - & $\sim$ & - & - & - & - & - & $\sim$ & - & - & - & $M$ & - & - & - & - & - & 으 & - & $\sim$ & $\sim$ & - \\
\hline 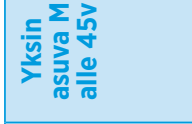 & - & - & - & $\sim$ & - & - & - & - & - & $\sim$ & - & - & - & $M$ & - & - & - & - & - & 으 & - & $\sim$ & $\sim$ & - \\
\hline 营 & 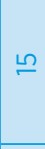 & 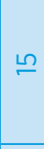 & $\stackrel{\varrho}{\curvearrowleft}$ & $\stackrel{\varrho}{\curvearrowleft}$ & $\stackrel{2}{\llcorner}$ & స & i & ㅇ. & ㅇ & i & $\stackrel{2}{\llcorner}$ & $M$ & $\stackrel{2}{2}$ & เn & $\stackrel{\Perp 2}{\llcorner}$ & 으 & $\stackrel{\curvearrowleft}{\curvearrowleft}$ & $\stackrel{2}{\llcorner}$ & $\stackrel{\llcorner}{\llcorner}$ & $\stackrel{\llcorner}{\sim}$ & 으 & in & in & L \\
\hline 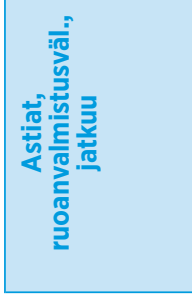 & 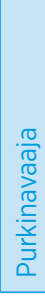 & $\begin{array}{l}\frac{\pi}{\pi} \\
\frac{\pi}{0} \\
\frac{0}{0} \\
\frac{1}{1} \\
\frac{1}{7}\end{array}$ & $\begin{array}{l}: \frac{\pi}{2} \\
: 0 \\
\frac{0}{0} \\
\frac{1}{45} \\
\end{array}$ & & $\frac{: 0}{\overline{\frac{0}{2}}}$ & 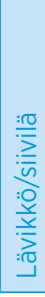 & 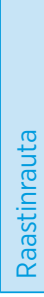 & 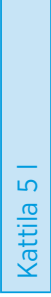 & \begin{tabular}{|l|}
$\bar{m}$ \\
$\frac{0}{\underline{\underline{T}}}$ \\
$\underline{\pi}$ \\
$\underline{\pi}$ \\
\end{tabular} & 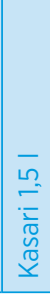 & 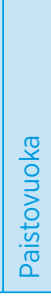 & 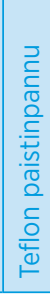 & 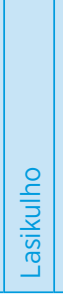 & 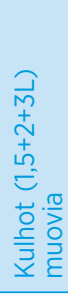 & 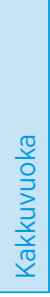 & 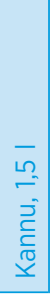 & 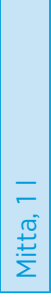 & 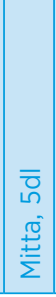 & 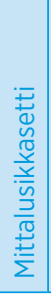 & 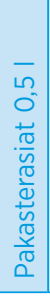 & 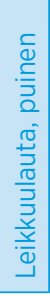 & 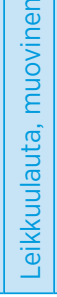 & 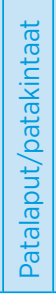 & $\begin{array}{l}\frac{0}{\frac{0}{5}} \\
\frac{1}{5} \\
\frac{0}{3} \\
\frac{1}{5}\end{array}$ \\
\hline
\end{tabular}


Liite 1 Hyödykeluettelo $\quad 4 / 14$

\begin{tabular}{|c|c|c|c|c|c|c|c|c|c|c|c|c|c|c|c|c|}
\hline 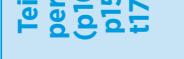 & & L & - & r & $\simeq$ & $\simeq$ & $\nabla$ & $\Xi$ & $\simeq$ & $\nabla$ & m & 으 & $\sim$ & $n$ & - & $\sim$ \\
\hline 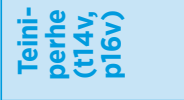 & & $\nabla$ & 6 & 6 & 으 & 으 & $\nabla$ & $\simeq$ & 으 & $\nabla$ & $m$ & 으 & $\sim$ & 0 & - & $\sim$ \\
\hline 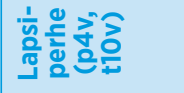 & & $\nabla$ & 6 & 6 & 으 & 으 & $\nabla$ & $\simeq$ & 으 & $\nabla$ & $m$ & 으 & $\sim$ & 6 & - & $\sim$ \\
\hline 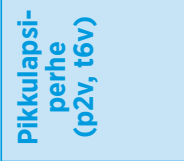 & & $\nabla$ & 6 & 6 & 으 & 으 & $\nabla$ & $\simeq$ & 으 & $\nabla$ & $\sim$ & $\infty$ & $\sim$ & เn & - & - \\
\hline 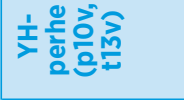 & & M & เn & เn & $\infty$ & $\infty$ & $\nabla$ & 으 & $\infty$ & $\nabla$ & $\sim$ & $\infty$ & $\sim$ & $\nabla$ & - & - \\
\hline 立导令 & & $N$ & $\nabla$ & $\nabla$ & 6 & 6 & $\sim$ & $\wedge$ & 6 & $\mathrm{~m}$ & - & $\nabla$ & $\sim$ & $m$ & - & - \\
\hline : & & $\sim$ & $\nabla$ & $\nabla$ & 6 & 6 & $\sim$ & 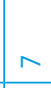 & 6 & $\mathrm{~m}$ & $v$ & 6 & $\sim$ & $\nabla$ & - & - \\
\hline 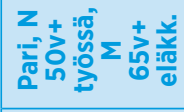 & & $\sim$ & $\nabla$ & $\nabla$ & 6 & 6 & $\sim$ & $r$ & 6 & $\mathrm{~m}$ & $\sim$ & 6 & $\sim$ & $\theta$ & - & - \\
\hline 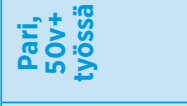 & & $\sim$ & $\nabla$ & $\nabla$ & 6 & 6 & $\sim$ & $r$ & 6 & $\mathrm{~m}$ & $\sim$ & 6 & $\sim$ & $\forall$ & - & - \\
\hline 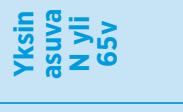 & & - & $m$ & $\mathrm{~m}$ & $\nabla$ & $M$ & $\sim$ & In & $\nabla$ & $\mathrm{m}$ & - & $\nabla$ & $\sim$ & $M$ & - & - \\
\hline 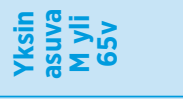 & & - & m & $\mathrm{m}$ & $\theta$ & $M$ & $\sim$ & In & $\nabla$ & m & - & $\nabla$ & $\sim$ & $m$ & - & - \\
\hline 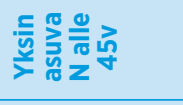 & & - & $m$ & $\mathrm{~m}$ & $\nabla$ & $M$ & $\sim$ & in & $\nabla$ & m & - & $\nabla$ & - & $\sim$ & - & - \\
\hline 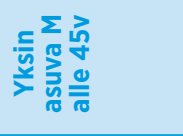 & & - & $m$ & $\mathrm{~m}$ & $\nabla$ & $M$ & $\sim$ & L & $\nabla$ & m & - & $\nabla$ & - & $\sim$ & - & - \\
\hline & & $\simeq$ & $r$ & L & 6 & 으 & 6 & in & 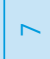 & $\stackrel{2}{\simeq}$ & 으 & 으 & i & 으 & 으 & 으 \\
\hline & 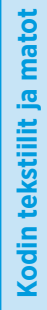 & $\begin{array}{l}\frac{0}{ \pm} \\
: \frac{1}{0} \\
: \frac{\pi}{\pi} \\
: \frac{1}{\pi} \\
0\end{array}$ & $\frac{0}{\frac{1}{0}}$ & $\stackrel{\gtrless}{\gtrless}$ & 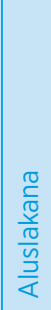 & 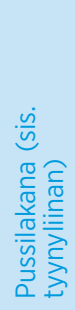 & 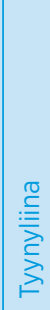 & 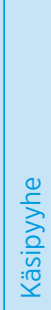 & 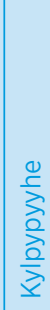 & 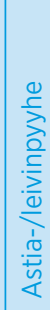 & 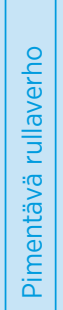 & $\mid$\begin{tabular}{c|}
+ \\
0 \\
$\frac{1}{2}$ \\
0 \\
3 \\
3 \\
in
\end{tabular} & 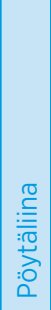 & $\frac{0}{ \pm}$ & 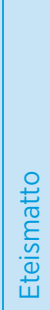 & 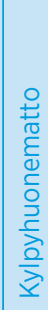 \\
\hline
\end{tabular}


Liite 1 Hyödykeluettelo $\quad 5 / 14$

\begin{tabular}{|c|c|c|c|c|c|c|c|c|c|c|c|c|c|c|c|c|c|c|c|}
\hline ஃஃ๐ & เ & ○ & 0 & - & - & 0 & $m$ & $m$ & $m$ & - & - & - & - & - & - & $\sim$ & $\llcorner\Omega$ & $\sigma$ & - \\
\hline 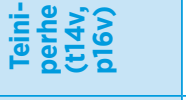 & $\nabla$ & ○ & 0 & - & - & 0 & $\sim$ & $\sim$ & $\sim$ & - & - & - & - & - & - & $\sim$ & $\nabla$ & $\infty$ & - \\
\hline 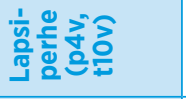 & $M$ & - & - & - & - & 0 & - & - & $\sim$ & - & - & - & - & - & - & $\sim$ & $m$ & $\infty$ & - \\
\hline 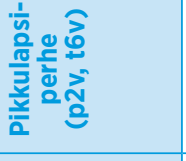 & $\sim$ & $\sim$ & $\sim$ & - & - & - & $\circ$ & 0 & $N$ & - & - & - & - & - & - & $\sim$ & $m$ & $\wedge$ & - \\
\hline 立这흘을 & $M$ & 0 & ○ & - & - & 0 & $\sim$ & $\sim$ & $\sim$ & - & - & - & - & - & - & - & $m$ & $\wedge$ & - \\
\hline 立这蛋 & - & - & - & - & - & 0 & 0 & 0 & - & - & - & 0 & - & - & - & - & - & เn & - \\
\hline 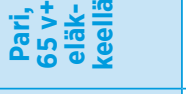 & $\sim$ & 0 & 0 & - & - & 0 & 0 & $\circ$ & - & - & - & 0 & - & - & - & $\sim$ & $\sim$ & เn & - \\
\hline 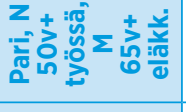 & $\sim$ & 0 & ○ & - & - & 0 & $\circ$ & 0 & - & - & - & 0 & - & - & - & $\sim$ & $\sim$ & $\llcorner\Omega$ & - \\
\hline 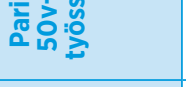 & $\sim$ & 0 & 0 & - & - & 0 & 0 & 0 & - & - & - & 0 & - & - & - & $\sim$ & $\sim$ & เn & - \\
\hline 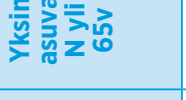 & - & 0 & ○ & - & - & 0 & $\circ$ & 0 & - & - & - & 0 & - & - & - & - & - & \llcorner & - \\
\hline 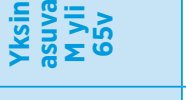 & - & 0 & 0 & - & - & 0 & 0 & 0 & - & - & - & 0 & - & - & - & - & - & เn & - \\
\hline 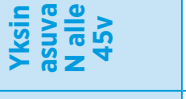 & - & 0 & 0 & - & - & 0 & 0 & 0 & - & - & - & 0 & - & - & - & - & - & $\nabla$ & - \\
\hline 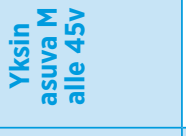 & - & 0 & 0 & - & - & 0 & 0 & 0 & - & - & - & 0 & - & - & - & - & - & $\nabla$ & - \\
\hline 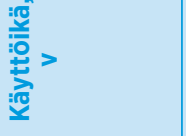 & $\stackrel{\curvearrowleft}{\llcorner}$ & $\stackrel{\llcorner}{\llcorner}$ & $r$ & $\stackrel{\curvearrowleft}{\varrho}$ & $\stackrel{\curvearrowleft}{\llcorner}$ & 으 & 尺ి & ণ & $\curvearrowleft$ & ㅇ & \llcorner & $\stackrel{\llcorner}{\llcorner}$ & $\stackrel{\varrho}{\curvearrowleft}$ & 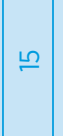 & 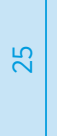 & ○ & ㄱ & ㄱ & ㄱ. \\
\hline 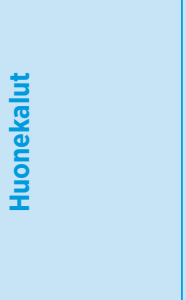 & 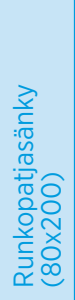 & 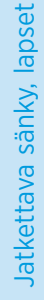 & 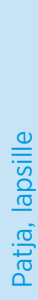 & 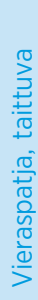 & 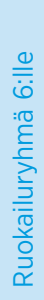 & 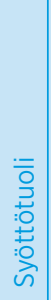 & 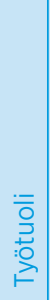 & 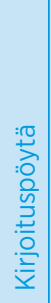 & 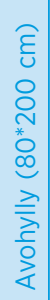 & 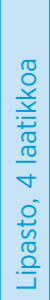 & 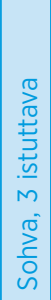 & 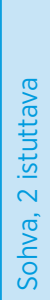 & $\begin{array}{l}: \pi \\
: 0 \\
: 0 \\
20 \\
0 \\
2 \\
0 \\
0 \\
0\end{array}$ & $\begin{array}{c}\stackrel{0}{0} \\
\stackrel{D}{0} \\
\stackrel{1}{1} \\
\vdash\end{array}$ & 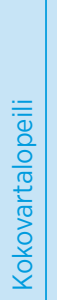 & $\begin{array}{l}: 0 \\
: 00 \\
: 0 \\
: 0\end{array}$ & 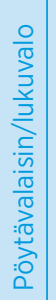 & 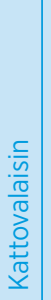 & 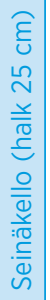 \\
\hline
\end{tabular}




\begin{tabular}{|c|c|c|c|c|c|c|c|c|c|c|c|c|c|c|c|c|c|c|}
\hline 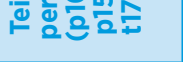 & $\sim$ & - & $\sim$ & 으 & $\sim$ & - & - & - & $\sim$ & $\sim$ & - & - & - & $\sim$ & 으 & $\simeq$ & - & - \\
\hline 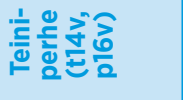 & $\sim$ & - & - & 으 & $\sim$ & - & - & - & $\sim$ & $\sim$ & - & - & - & $\sim$ & 음 & $\simeq$ & - & - \\
\hline 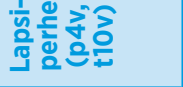 & $\sim$ & - & - & 으 & $\sim$ & - & - & - & $\sim$ & $\sim$ & - & - & - & $\sim$ & ㅇ & 으 & - & - \\
\hline 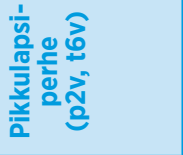 & $\sim$ & - & - & 으 & $\sim$ & - & - & - & $\sim$ & $\sim$ & - & - & - & $\sim$ & 尺 & $\stackrel{ }{\circ}$ & - & - \\
\hline 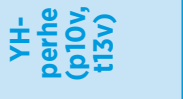 & $\sim$ & - & - & 으 & $\sim$ & - & - & - & $\sim$ & $\sim$ & - & - & - & - & $\stackrel{\curvearrowright}{v}$ & 으 & - & - \\
\hline 亡芒究怘 & $\sim$ & - & - & 으 & $v$ & - & - & - & $\sim$ & - & - & - & - & - & 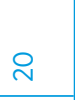 & เก & - & - \\
\hline ฮัน็ำ & $\sim$ & - & - & 으 & $\sim$ & - & - & - & $\sim$ & - & - & - & - & - & $\stackrel{\text { N }}{ }$ & 으 & - & - \\
\hline 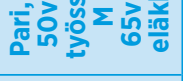 & $\sim$ & - & - & $\stackrel{ }{\circ}$ & $\sim$ & - & - & - & $\sim$ & - & - & - & - & - & 尺 & 으 & - & - \\
\hline '0 & $\sim$ & - & - & 으 & $v$ & - & - & - & $\sim$ & - & - & - & - & - & ৩ & 으 & - & - \\
\hline 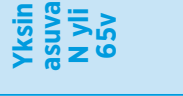 & $v$ & - & - & 으 & $\sim$ & - & - & - & - & - & - & - & - & - & 으 & In & - & - \\
\hline 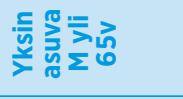 & $\sim$ & - & - & 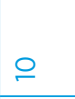 & $\sim$ & - & - & - & - & - & - & - & - & - & 으 & เก & - & - \\
\hline 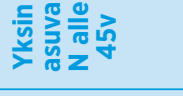 & - & - & - & 으 & $v$ & - & - & - & - & - & - & - & - & - & 으 & เ & - & - \\
\hline 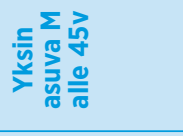 & - & - & - & 으 & $v$ & - & - & - & - & - & - & - & - & - & 으 & in & - & - \\
\hline & - & $\sim$ & $\nabla$ & - & n & in & 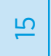 & in & $\simeq$ & $\simeq$ & 으 & ㅇ & ㄱ & ㅇ & ํ & ㅇ & ○ & 이 \\
\hline 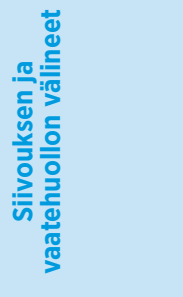 & 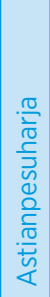 & 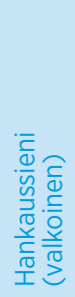 & $\begin{array}{l}\frac{0}{\pi} \\
\frac{\pi}{5} \\
\dot{u} \\
3\end{array}$ & 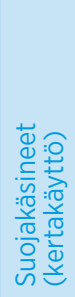 & 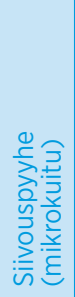 & 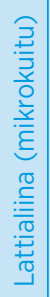 & 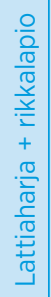 & 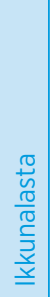 & 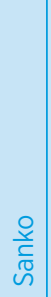 & 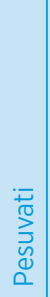 & 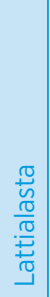 & 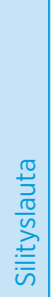 & 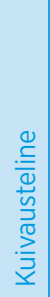 & 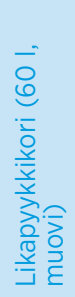 & 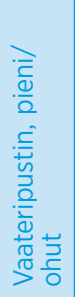 & 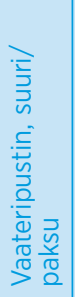 & 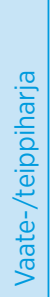 & 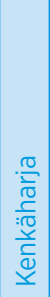 \\
\hline
\end{tabular}




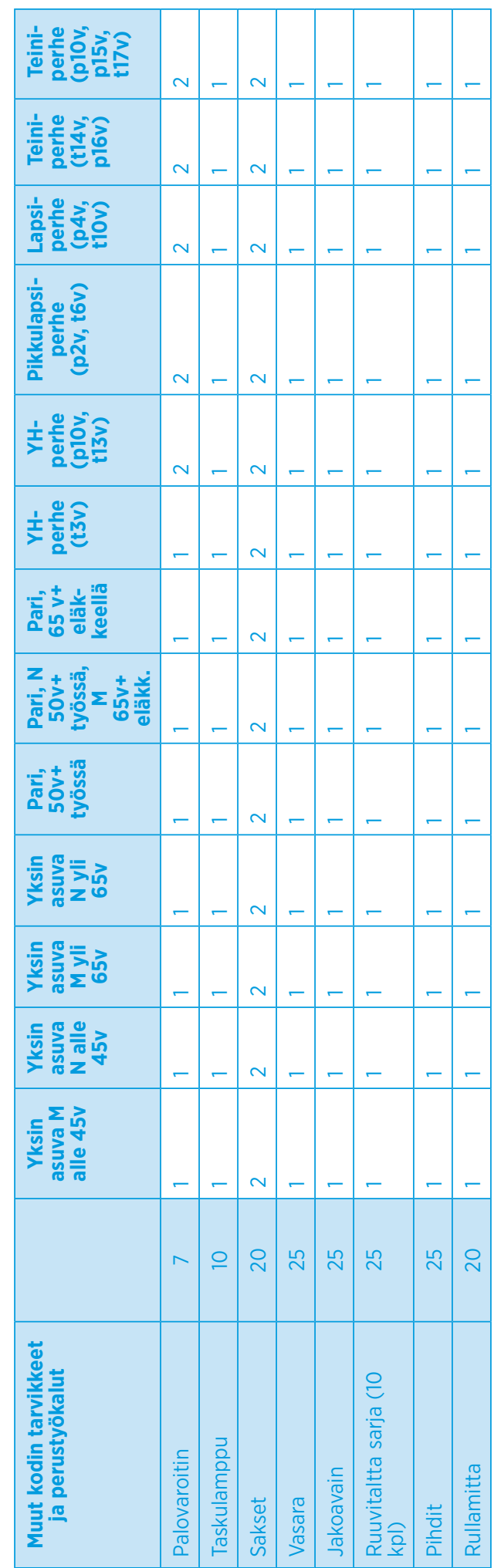




\begin{tabular}{|c|c|c|c|c|c|c|c|c|c|c|c|c|c|c|c|c|c|c|c|c|c|c|}
\hline 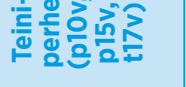 & & $\wedge$ & 8 & นก & \begin{tabular}{|l|l}
$\stackrel{1}{0}$ \\
$\varrho$
\end{tabular} & $\stackrel{n}{-}$ & 員 & ○ & $\stackrel{n}{-}$ & $\stackrel{2}{\sim}$ & 8 & 0 & $\nabla$ & - & - & $\stackrel{\llcorner}{\circ}$ & 0 & ৩ & $N$ & $\stackrel{\infty}{-1}$ & $\nabla$ & $\stackrel{2}{-}$ \\
\hline 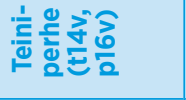 & & $\wedge$ & 8 & ঔ & $\tilde{N}$ & $\stackrel{\sim}{\sim}$ & 요 & ¿ & $\stackrel{\Omega}{-}$ & $\stackrel{\Perp}{=}$ & 8 & 6 & $\nabla$ & - & - & $\stackrel{M}{ }$ & 0 & $\stackrel{\sim}{\sim}$ & $\sim$ & $\bullet$ & $\nabla$ & - \\
\hline 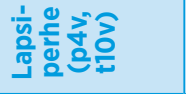 & & $n$ & 8 & $\stackrel{\varphi}{+}$ & $\stackrel{N}{\sim}$ & $\stackrel{\sim}{\sim}$ & 8 & 은 & $\stackrel{\Omega}{=}$ & $\stackrel{\Omega}{=}$ & 8 & 6 & $m$ & $\stackrel{\text { no }}{0}$ & - & $\simeq$ & 0 & $\stackrel{\sim}{\sim}$ & $\sim$ & \pm & $\nabla$ & $\stackrel{4}{0}$ \\
\hline 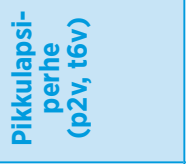 & & $\wedge$ & ○ & $\stackrel{\infty}{+}$ & $\stackrel{N}{\sim}$ & $\stackrel{\sim}{\sim}$ & 8 & $\stackrel{\circ}{\circ}$ & $\stackrel{\sim}{=}$ & $\stackrel{\Perp}{-}$ & 8 & 6 & $m$ & $\stackrel{n}{0}$ & - & 으 & 6 & $\stackrel{\sim}{ }$ & - & $\simeq$ & $\nabla$ & 0 \\
\hline 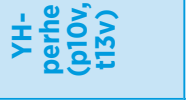 & & $n$ & 웅 & $\stackrel{M}{M}$ & の & $\stackrel{\llcorner}{\sim}$ & 8 & 只 & $\stackrel{\Omega}{=}$ & $\stackrel{\llcorner}{=}$ & 8 & 6 & $m$ & 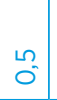 & - & 으 & 0 & $\stackrel{\sim}{\sim}$ & - & $\simeq$ & $\nabla$ & - \\
\hline 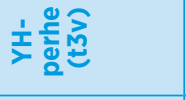 & & in & 오 & 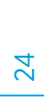 & $\begin{array}{l}0 \\
\end{array}$ & - & $\begin{array}{l}8 \\
0 \\
\end{array}$ & 음 & - & - & in & เ & $\sim$ & $\begin{array}{l}\llcorner \\
0 \\
0\end{array}$ & $\begin{array}{l}\llcorner \\
0 \\
0\end{array}$ & $\infty$ & 0 & $\stackrel{\sim}{\text { N }}$ & - & 으 & $\nabla$ & 0 \\
\hline 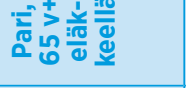 & & in & 움 & $\approx$ & 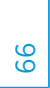 & - & ৪৪ & 으 & - & - & 유 & เn & $\sim$ & $\stackrel{\llcorner}{0}$ & 0 & $\infty$ & 0 & จ & - & 으 & $\nabla$ & 0 \\
\hline 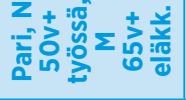 & & 㘦 & 웅 & $\approx$ & 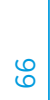 & - & ং & 음 & - & - & 유 & ا & $\sim$ & $\stackrel{L}{L}$ & 0 & $\infty$ & 0 & 尺 & - & 으 & $\nabla$ & 0 \\
\hline 흄유유 & & in & 웅 & $\approx$ & 8 & - & 8 & ○ & - & - & 유 & in & $\sim$ & $\stackrel{L}{L}$ & 0 & $\infty$ & 0 & $\stackrel{\sim}{\sim}$ & - & 으 & $\nabla$ & 0 \\
\hline 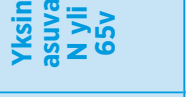 & & in & 움 & $=$ & $M$ & - & ৪ & 음 & - & - & 유 & in & $\stackrel{\llcorner}{-}$ & $\stackrel{2}{0}$ & 0 & $r$ & 0 & $\stackrel{\sim}{*}$ & - & 으 & $\nabla$ & 0 \\
\hline 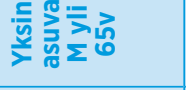 & & in & 움 & $=$ & $\stackrel{M}{m}$ & $\stackrel{1}{2} 0$ & ৪ & 으 & - & - & 유 & in & $\stackrel{\llcorner}{\sim}$ & $\stackrel{2}{0}$ & 0 & $r$ & 0 & $\stackrel{\sim}{\circ}$ & - & 으 & $\nabla$ & 0 \\
\hline 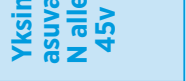 & & 片 & $\stackrel{i}{i}$ & $=$ & $\stackrel{m}{m}$ & $\begin{array}{l}n \\
0 \\
0\end{array}$ & 8 & 으 & - & - & 유 & in & $\stackrel{\llcorner}{\sim}$ & $\stackrel{2}{0}$ & 0 & 6 & 0 & $\stackrel{\sim}{*}$ & - & 으 & $\nabla$ & 0 \\
\hline 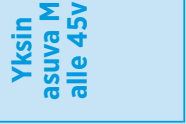 & 迹元之 & เn & $\stackrel{i}{i}$ & $=$ & 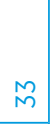 & $\begin{array}{l}1 \\
0 \\
0\end{array}$ & 8 & 으 & - & - & 요 & เn & $\stackrel{\llcorner\Omega}{-}$ & 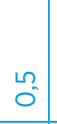 & 0 & 6 & 0 & $\stackrel{\sim}{~}$ & - & 으 & $\nabla$ & 0 \\
\hline & 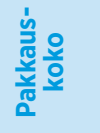 & $\stackrel{\llcorner}{ }$ & ২ & 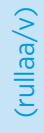 & $\begin{array}{l}\frac{2}{3} \\
\frac{0}{5} \\
\frac{0}{3}\end{array}$ & - & $\frac{\frac{2}{a}}{\frac{a}{3}}$ & 으 & - & - & $\frac{3}{\frac{2}{z}}$ & $\frac{3}{\frac{z}{2}}$ & - & - & - & 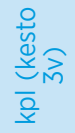 & $\frac{2}{\frac{2}{2}}$ & $\frac{2}{\frac{2}{2}}$ & $\sim$ & $\simeq$ & $\simeq$ & - \\
\hline 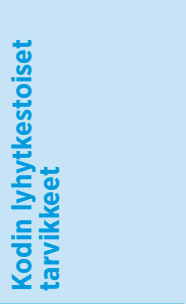 & 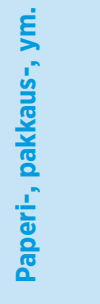 & 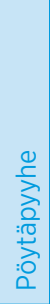 & 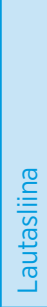 & $\begin{array}{l}\frac{1}{0} \\
\frac{0}{10} \\
\frac{0}{0} \\
\frac{0}{0} \\
\frac{0}{10}\end{array}$ & $\begin{array}{l}\overline{\bar{\alpha}} \\
\frac{0}{0} \\
\frac{0}{0} \\
\dot{u} \\
3\end{array}$ & 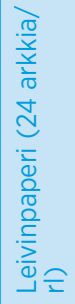 & 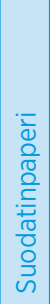 & 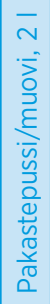 & 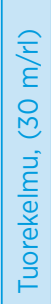 & 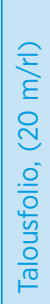 & 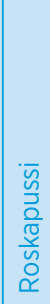 & 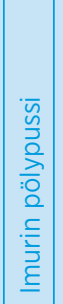 & $\frac{\bar{a}}{\bar{Q}}$ & 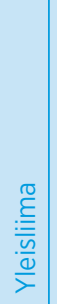 & 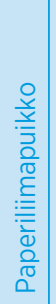 & 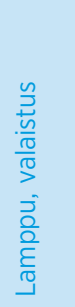 & 茎 & 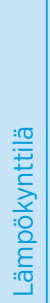 & 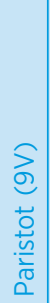 & 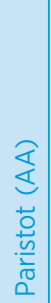 & 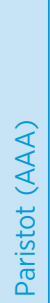 & 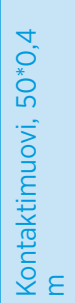 \\
\hline
\end{tabular}




\begin{tabular}{|c|c|c|c|c|c|c|c|c|c|c|c|c|c|c|c|c|c|c|c|c|c|}
\hline 은 둥응믕종 & & $\stackrel{\llcorner}{\sim}$ & $\stackrel{6}{M}$ & 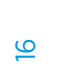 & $\sim$ & - & - & & $\sim$ & $N$ & $\nabla$ & in & $\sim$ & - & ㅇ & $\infty$ & $\circ$ & ঙํ & $\stackrel{ }{=}$ & 0 & $\widetilde{\widetilde{\sigma}}$ \\
\hline 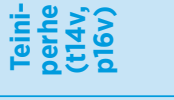 & & $\stackrel{\sim}{\sim}$ & $\bar{m}$ & $\stackrel{n}{\llcorner}$ & $\sim$ & $\begin{array}{l}L_{0} \\
0\end{array}$ & - & & $\sim$ & $\sim$ & $\nabla$ & $\forall$ & $\sim$ & - & i & $\infty$ & 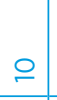 & $\frac{O}{m}$ & 으 & 0 & $\cong$ \\
\hline 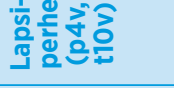 & & $\stackrel{\sim}{\sim}$ & $\bar{m}$ & $\stackrel{ㅇ}{\llcorner}$ & $\sim$ & $\begin{array}{l}L_{0} \\
0\end{array}$ & - & & $\sim$ & $\sim$ & $\nabla$ & $\nabla$ & $\sim$ & - & i & $\infty$ & 으 & $\frac{O}{m}$ & ৪ & 0 & ్ㅡ \\
\hline 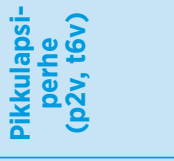 & & $\stackrel{\sim}{\sim}$ & $\bar{m}$ & $\stackrel{\llcorner 0}{\circ}$ & $v$ & $\begin{array}{l}L_{0} \\
0\end{array}$ & - & & $\sim$ & $v$ & $m$ & $\nabla$ & $\sim$ & - & i & $\infty$ & 으 & $\frac{O}{m}$ & $\infty$ & 0 & $\widetilde{\Xi}$ \\
\hline 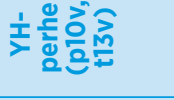 & & $\stackrel{\sim}{\sim}$ & $\stackrel{6}{i}$ & $\simeq$ & $\sim$ & 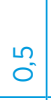 & - & & $\sim$ & $\sim$ & $m$ & $m$ & $\sim$ & - & i & $\infty$ & 으 & $\frac{O}{m}$ & $\begin{array}{l}\stackrel{Q}{\sim} \\
\sim\end{array}$ & $\begin{array}{l}0 \\
0^{-}\end{array}$ & 으 \\
\hline 立这产 & & $\sim$ & $\stackrel{6}{\sim}$ & $\infty$ & $\stackrel{\sim}{\sim}$ & $\begin{array}{l}\tilde{L}_{0} \\
0\end{array}$ & $\stackrel{1}{0}$ & & - & - & $\sim$ & $\sim$ & - & - & $\simeq$ & 几n & (n) & $\stackrel{\bigcirc}{\stackrel{\infty}{2}}$ & $\stackrel{尺}{\simeq}$ & $m$ & $\bar{\gamma}$ \\
\hline 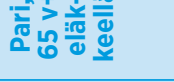 & & $\sim$ & 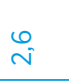 & $\infty$ & $\stackrel{\llcorner}{\sim}$ & $\stackrel{2}{0} 0^{\circ}$ & - & & $\sim$ & - & $m$ & $v$ & - & - & m & เ & $\infty$ & $\stackrel{\circ}{\Perp}$ & $\stackrel{\stackrel{P}{\sim}}{\sim}$ & $\begin{array}{l}\infty \\
\nabla^{\prime}\end{array}$ & 0 \\
\hline 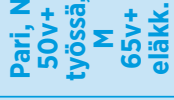 & & $\sim$ & $\bar{\sim}$ & $\infty$ & - & $\begin{array}{l}n \\
0 \\
0\end{array}$ & - & & $\sim$ & - & $m$ & $\sim$ & - & - & i & $n$ & $\infty$ & 윰 & $\stackrel{\text { O }}{\sim}$ & $\stackrel{+}{\kappa}$ & 0 \\
\hline 흠융ํㅀ & & $\sim$ & $\bar{v}$ & $\infty$ & - & $\begin{array}{l}u_{0} \\
0\end{array}$ & - & & $\sim$ & - & $m$ & $\sim$ & - & - & i & เ & $\infty$ & 요 & $\stackrel{\circ}{\sim}$ & 0 & 0 \\
\hline 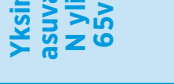 & & $\stackrel{\llcorner}{\sim}$ & 0 & $\nabla$ & - & $\begin{array}{l}10 \\
0 \\
0\end{array}$ & $\stackrel{\llcorner}{0}$ & & - & - & $\sim$ & $\sim$ & - & - & ৩ & 几n & in & ○ & $\stackrel{\searrow}{\beth}$ & $m$ & 0 \\
\hline 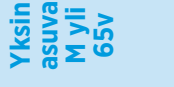 & & $\stackrel{\sim}{\sim}$ & $\circ$ & $\nabla$ & - & $\begin{array}{l}L_{0} \\
0\end{array}$ & $\stackrel{\llcorner}{0}$ & & - & - & $\sim$ & $\sim$ & - & - & ㅇ & 几n & เ & 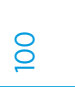 & $\stackrel{\beth}{\simeq}$ & $m$ & 0 \\
\hline 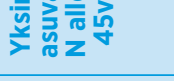 & & $\sim$ & 0 & $\nabla$ & - & $\stackrel{2}{0}$ & $\stackrel{\text { Ln }}{0}$ & & - & - & $\sim$ & $\sim$ & - & - & $\circ$ & $n$ & 几n & ○ & $\stackrel{\bigcirc}{\simeq}$ & $m$ & 0 \\
\hline 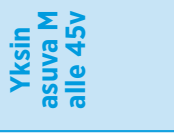 & 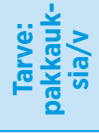 & $\sim$ & $\circ$ & $\nabla$ & - & $\begin{array}{l}u_{0} \\
0\end{array}$ & $\stackrel{2}{0}$ & & - & - & $\sim$ & $\sim$ & - & - & 으 & 几n & n & 음 & $\stackrel{\searrow}{\simeq}$ & $m$ & 0 \\
\hline & 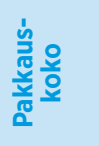 & $\begin{array}{l}\bar{\varepsilon} \\
\varnothing \\
\varnothing\end{array}$ & 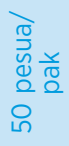 & 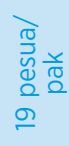 & $\begin{array}{l}\frac{7}{n+} \\
\frac{1}{0} \\
0^{0}\end{array}$ & $\begin{array}{l}\frac{0}{2} \\
\text { हे } \\
\text { 옷 }\end{array}$ & $\begin{array}{l}\frac{0}{2} \\
\frac{2}{\hat{\varepsilon}} \\
\text { 읏 }\end{array}$ & 군 & $\overline{\frac{\rho}{9}}$ & $\overline{\frac{a}{x}}$ & $\frac{\bar{a}}{x}$ & $\frac{\bar{a}}{x}$ & $\begin{array}{l}> \\
\frac{10}{2} \\
\frac{a}{2}\end{array}$ & $\overline{\frac{\rho}{x}}$ & $\overline{\bar{a}}$ & $\overline{\frac{a}{a}}$ & $\overline{\frac{a}{x}}$ & $\begin{array}{l}\frac{3}{\sqrt{0}} \\
\frac{0}{3} \\
\text { d }\end{array}$ & 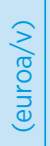 & $\begin{array}{l}\bar{\alpha} \\
\frac{\bar{\alpha}}{\alpha} \\
o \\
\mathrm{~m}\end{array}$ & $\begin{array}{l}\frac{3}{10} \\
\frac{0}{3} \\
\text { O্ }\end{array}$ \\
\hline & 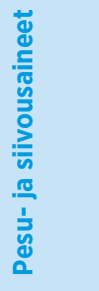 & 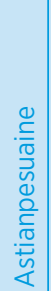 & 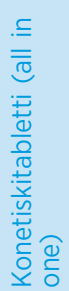 & 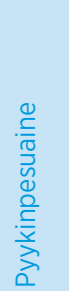 & 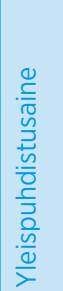 & 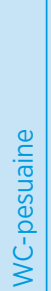 & 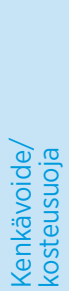 & 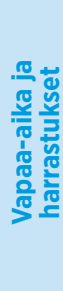 & 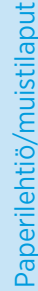 & 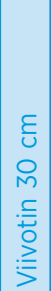 & 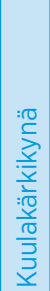 & 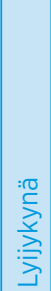 & 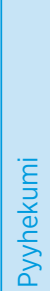 & 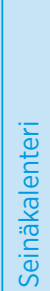 & 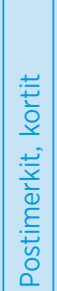 & 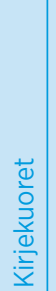 & $\frac{\overrightarrow{0}}{\frac{0}{2}}$ & 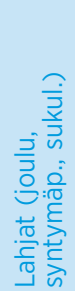 & 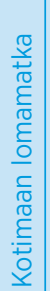 & 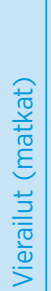 & 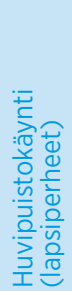 \\
\hline
\end{tabular}




\begin{tabular}{|c|c|c|c|c|c|c|c|c|c|c|c|c|c|c|c|c|c|c|c|c|c|}
\hline$\approx$ & $M$ & n & $m$ & $\sim$ & $\sim$ & & $\wedge$ & 으 & $\stackrel{\llcorner}{\llcorner}$ & $\stackrel{\llcorner}{\llcorner}$ & $m$ & $\wedge$ & $\simeq$ & $\stackrel{10}{\sim}$ & $\nabla$ & & $m$ & $m$ & $m$ & (n) & $M$ \\
\hline 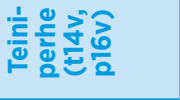 & $\sim$ & $\nabla$ & $\sim$ & $N$ & $\sim$ & & 0 & $\sigma$ & $\simeq$ & $\simeq$ & $\stackrel{n}{\sim}$ & 0 & $\simeq$ & $\stackrel{n}{\sim}$ & $\nabla$ & & $m$ & $m$ & $m$ & \llcorner & $\mathrm{M}$ \\
\hline 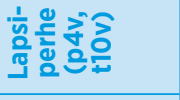 & $\sim$ & $\nabla$ & - & $\sim$ & $\sim$ & & 6 & $\infty$ & $\simeq$ & $\simeq$ & $\sim$ & 0 & 0 & $\sim$ & $\nabla$ & & $\sim$ & $\sim$ & $\sim$ & $\nabla$ & $\sim$ \\
\hline 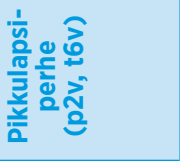 & - & $\nabla$ & 0 & $\sim$ & $\sim$ & & 0 & $\infty$ & $\simeq$ & $\simeq$ & $\sim$ & 6 & 0 & $\sim$ & $\nabla$ & & $\sim$ & $\sim$ & $\sim$ & $\nabla$ & $\sim$ \\
\hline 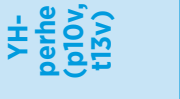 & $\sim$ & $M$ & $\sim$ & - & - & & เn & $\infty$ & $\sigma$ & $\sigma$ & $\sim$ & \llcorner & 6 & $\sim$ & $\nabla$ & & $m$ & $m$ & $m$ & $\nabla$ & 0 \\
\hline 主突胥 & 0 & - & 0 & - & - & & $m$ & $\forall$ & 6 & 6 & - & $M$ & $m$ & - & $\sim$ & & $\sim$ & $\sim$ & $\sim$ & $\sim$ & 0 \\
\hline 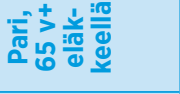 & 0 & $\sim$ & $\circ$ & $\sim$ & $\sim$ & & $\nabla$ & $\wedge$ & 0 & 0 & $\sim$ & $\nabla$ & $\nabla$ & $\sim$ & $\nabla$ & & $m$ & $\sim$ & $\sim$ & $m$ & - \\
\hline 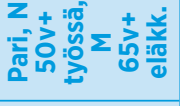 & 0 & $\sim$ & 0 & $\sim$ & $\sim$ & & $m$ & $\lambda$ & 6 & 6 & $\sim$ & $\nabla$ & $\nabla$ & $v$ & $\nabla$ & & $v$ & $\sim$ & $\sim$ & $m$ & - \\
\hline 일 & 0 & $\sim$ & 0 & $\sim$ & $\sim$ & & $m$ & $\wedge$ & 6 & 6 & $\sim$ & $\nabla$ & $\nabla$ & $v$ & $\nabla$ & & $\sim$ & $\sim$ & $\sim$ & $m$ & - \\
\hline 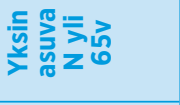 & 0 & - & 0 & - & - & & $\sim$ & $\stackrel{L}{\forall}$ & $\mathrm{m}$ & $m$ & - & $\sim$ & $\sim$ & - & $\sim$ & & $\sim$ & $\sim$ & $\sim$ & $\sim$ & 0 \\
\hline 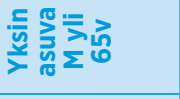 & 0 & - & 0 & - & - & & $\sim$ & $\stackrel{n}{\forall}$ & $M$ & $m$ & - & $\sim$ & $\sim$ & - & $\sim$ & & 0 & 0 & $\circ$ & $\sim$ & - \\
\hline 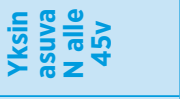 & 0 & - & 0 & - & - & & $\sim$ & $\stackrel{L}{\forall}$ & $M$ & $m$ & - & $\sim$ & $m$ & - & $\sim$ & & $\sim$ & $\sim$ & $\sim$ & $\sim$ & 0 \\
\hline 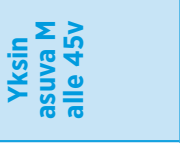 & $\circ$ & - & 0 & - & - & & $\sim$ & $\underset{\nabla}{*}$ & $M$ & $m$ & - & $\sim$ & $m$ & - & $\sim$ & & ○ & 0 & $\circ$ & $\sim$ & $\sim$ \\
\hline$\sum_{\frac{3}{4}}$ & $\begin{array}{l}\bar{a} \\
\frac{a}{d} \\
ㅇ\end{array}$ & $\begin{array}{l}\text { ì } \\
\text { d } \\
\stackrel{ }{ป}\end{array}$ & $\begin{array}{l}\text { z } \\
8 \\
8 \\
8 \\
\text { d }\end{array}$ & 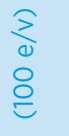 & $\begin{array}{l}\stackrel{2}{8} \\
\text { 웅 }\end{array}$ & 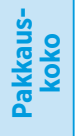 & $\begin{array}{l}\bar{E} \\
\circ \\
\circ\end{array}$ & $\begin{array}{l}\bar{E} \\
\text { ○ }\end{array}$ & $\frac{\bar{\alpha}}{x}$ & $\begin{array}{l}\bar{E} \\
\underline{N}\end{array}$ & $\begin{array}{l}E \\
\text { 유 }\end{array}$ & $\begin{array}{l}\circ \\
\circ \\
\stackrel{\leftrightarrow}{n}\end{array}$ & $\frac{\bar{a}}{\frac{2}{x}}$ & $\begin{array}{l}\bar{\varepsilon} \\
\stackrel{\sim}{~}\end{array}$ & $\begin{array}{l}\bar{\varepsilon} \\
\varnothing \\
\end{array}$ & & $\begin{array}{l}\bar{\varepsilon} \\
\varnothing \\
\end{array}$ & $\begin{array}{l}\bar{\varepsilon} \\
\varnothing \\
\stackrel{N}{~}\end{array}$ & $\begin{array}{l}\bar{\varepsilon} \\
\grave{N}\end{array}$ & $\overline{\frac{a}{x}}$ & $\begin{array}{l}\bar{E} \\
\varnothing \\
\varnothing\end{array}$ \\
\hline 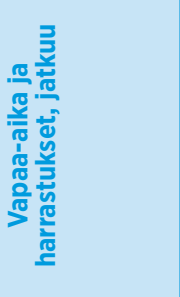 & 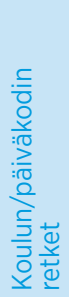 & 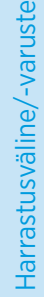 & 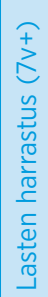 & 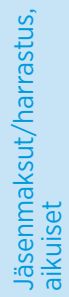 & 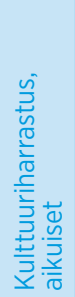 & 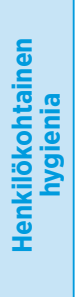 & 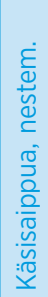 & 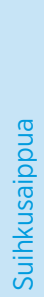 & $\begin{array}{l}\frac{\pi}{\frac{0}{\pi}} \\
\frac{\pi}{n} \\
\frac{\pi}{\xi} \\
\frac{\varepsilon}{1} \\
\frac{\pi}{1}\end{array}$ & 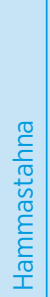 & 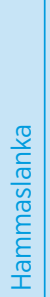 & $\begin{array}{l}\frac{0}{0} \\
\frac{0}{2} \\
\frac{3}{2} \\
\frac{0}{0}\end{array}$ & 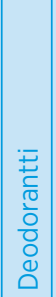 & 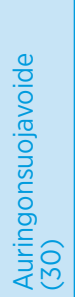 & 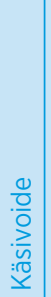 & 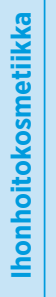 & 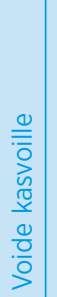 & 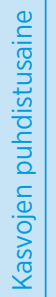 & 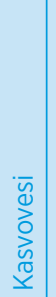 & 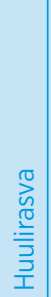 & $\begin{array}{l}\frac{0}{0} \\
\frac{0}{9} \\
1 \\
0 \\
0 \\
\frac{0}{4} \\
\frac{1}{n} \\
\frac{0}{0} \\
\frac{4}{4}\end{array}$ \\
\hline
\end{tabular}




\begin{tabular}{|c|c|c|c|c|c|c|c|c|c|c|c|c|c|c|c|c|c|c|c|}
\hline 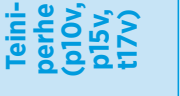 & $\sim$ & $\sim$ & $M$ & $\stackrel{1}{\sim}$ & $\sim$ & & $\simeq$ & $\infty$ & $\nabla$ & 으 & $M$ & & $\Xi$ & $\simeq$ & 6 & $\Lambda$ & $\forall$ & - & $\stackrel{1}{0}$ \\
\hline 立导守它 & $v$ & $v$ & $M$ & $N$ & - & & 으 & $\lambda$ & $\nabla$ & ㅇ & 0 & & $\simeq$ & $\simeq$ & 6 & 6 & $\forall$ & - & $\tilde{1}$ \\
\hline 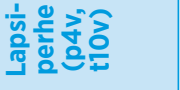 & - & - & $\sim$ & $N$ & - & & $\sigma$ & เn & $\stackrel{\sim}{\sim}$ & $F$ & 6 & & $\simeq$ & 0 & $M$ & 几 & $M$ & $\begin{array}{l}n \\
0\end{array}$ & $\stackrel{1}{0}$ \\
\hline 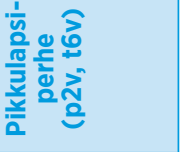 & - & - & $\sim$ & $\sim$ & - & & $\infty$ & $\nabla$ & $\sim$ & $F$ & ما & & $\simeq$ & $\bullet$ & $M$ & م & $M$ & $\stackrel{1}{0}$ & $\stackrel{1}{\tilde{0}}$ \\
\hline 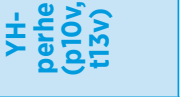 & - & $N$ & $N$ & $\sim$ & - & & $\infty$ & $\nabla$ & $M$ & $\sigma$ & $\forall$ & & 으 & $\simeq$ & 6 & $\forall$ & $M$ & $\stackrel{0}{0}$ & $\begin{array}{l}\tilde{0} \\
0\end{array}$ \\
\hline 立起蛋 & $\sim$ & - & $N$ & $N$ & $\sim$ & & $\nabla$ & $\sim$ & - & เก & $N$ & & $\forall$ & 6 & $M$ & $M$ & $\stackrel{2}{=}$ & 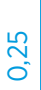 & $\begin{array}{l}\tilde{0} \\
0 \\
0\end{array}$ \\
\hline 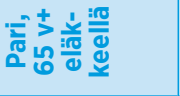 & - & - & - & - & - & & 6 & $M$ & - & 으 & 0 & & 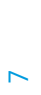 & $M$ & $M$ & $M$ & $\sim$ & $\mathrm{M}^{\mathrm{O}}$ & $\begin{array}{l}\stackrel{\sim}{\simeq} \\
0^{\prime}\end{array}$ \\
\hline 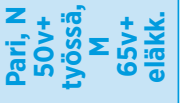 & - & - & $\sim$ & - & - & & 6 & $m$ & $\sim$ & 으 & 0 & & $\Lambda$ & $M$ & $M$ & $M$ & $\sim$ & $\begin{array}{c}M \\
0\end{array}$ & $\begin{array}{l}\stackrel{\sim}{\sim} \\
0\end{array}$ \\
\hline 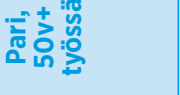 & - & - & $\sim$ & - & - & & 6 & $M$ & $\sim$ & $=$ & 0 & & $\Lambda$ & $M$ & $M$ & $M$ & $\sim$ & $\mathrm{M}^{\mathrm{O}}$ & $\stackrel{\stackrel{\sim}{N}}{\tilde{O}^{\prime}}$ \\
\hline 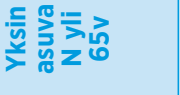 & - & - & - & - & - & & $M$ & $\sim$ & $\sim$ & เก & 0 & & $\checkmark$ & 0 & 0 & $\stackrel{2}{-}$ & - & $\stackrel{\stackrel{n}{N}}{\tilde{O}^{\prime}}$ & $\stackrel{\stackrel{\sim}{N}}{\stackrel{0}{0}}$ \\
\hline 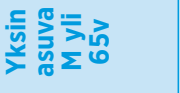 & 0 & 0 & 0 & 0 & 0 & & $M$ & $\sim$ & 0 & เn & 0 & & $\nabla$ & 0 & 0 & $\stackrel{2}{-}$ & - & $\stackrel{N}{0}$ & 0 \\
\hline 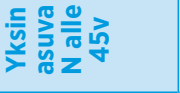 & $\sim$ & - & $\sim$ & $\sim$ & $\sim$ & & $M$ & $\sim$ & $\sim$ & เn & 0 & & $\checkmark$ & 0 & $M$ & $\stackrel{2}{=}$ & $\sim$ & $\stackrel{\stackrel{L}{N}}{\tilde{O}^{\prime}}$ & $\begin{array}{l}\tilde{n} \\
0 \\
0\end{array}$ \\
\hline 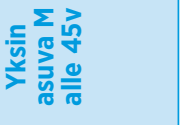 & 0 & 0 & 0 & 0 & 0 & & $M$ & $\sim$ & $\sim$ & 0 & 0 & 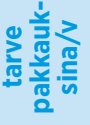 & $\forall$ & 0 & 0 & $\stackrel{n}{-}$ & - & $\tilde{O}^{N}$ & 0 \\
\hline & $\frac{\bar{\alpha}}{y}$ & $\begin{array}{l}\text { ס) } \\
\text { n? } \\
m\end{array}$ & $\begin{array}{l}\text { ठा } \\
\text { व }\end{array}$ & $\begin{array}{l}\bar{\varepsilon} \\
\stackrel{\mathrm{m}}{ }\end{array}$ & $\begin{array}{l}\text { व) } \\
\square\end{array}$ & & $\begin{array}{l}\bar{E} \\
\text { O } \\
\stackrel{\mathrm{N}}{\mathrm{N}}\end{array}$ & $\begin{array}{l}\bar{\varepsilon} \\
\text { ○ } \\
\text { ㄱ. }\end{array}$ & $\begin{array}{l}\bar{E} \\
\text { ○ } \\
\text { }\end{array}$ & 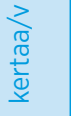 & $\begin{array}{l}2 \\
\frac{0}{0} \\
\frac{1}{1} \\
\frac{1}{2} \\
\frac{1}{1}\end{array}$ & & $\begin{array}{l}\frac{\overline{0}}{\frac{1}{8}} \\
\text { 응 }\end{array}$ & 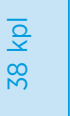 & $\begin{array}{l}\frac{\bar{\alpha}}{x} \\
\text { 윰 }\end{array}$ & $\begin{array}{l}\frac{\bar{a}}{x} \\
\text { 은 } \\
\text { ㄴ. }\end{array}$ & $\begin{array}{l}\frac{\bar{\alpha}}{\frac{1}{x}} \\
\\
\infty\end{array}$ & $\frac{\bar{a}}{6}$ & $\frac{\bar{\alpha}}{\frac{0}{x}}$ \\
\hline 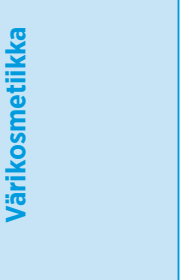 & $\begin{array}{l}\frac{\pi}{\pi} \\
\frac{\pi}{n} \\
\frac{0}{\bar{\alpha}}\end{array}$ & 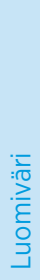 & $\begin{array}{l}\stackrel{0}{5} \\
\stackrel{\frac{0}{2}}{\overline{3}} \\
\text { 至 }\end{array}$ & $\frac{\frac{1}{0}}{\frac{0}{0}}$ & 产 & 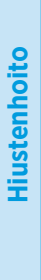 & 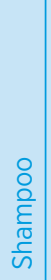 & 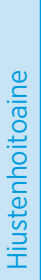 & 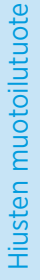 & 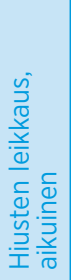 & 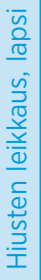 & 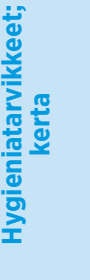 & 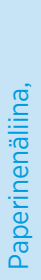 & 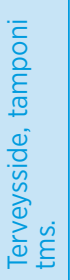 & 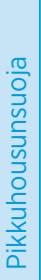 & 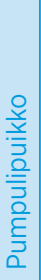 & 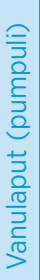 & 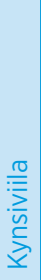 & 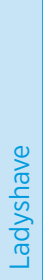 \\
\hline
\end{tabular}


Liite 1 Hyödykeluettelo $\quad$ 12/14

\begin{tabular}{|c|c|c|c|c|c|c|c|c|c|c|c|c|c|c|c|c|c|c|}
\hline 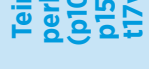 & in & - & $\sim$ & $\begin{array}{l}\infty \\
\sigma^{2}\end{array}$ & & $\sim$ & $M$ & in & in & $\sim$ & $m$ & 0 & $\sim$ & - & $\sim$ & $\sim$ & - & $\sim$ \\
\hline 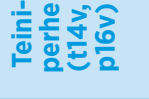 & $\nabla$ & - & $\sim$ & $\begin{array}{l}\infty \\
0^{-}\end{array}$ & & $\sim$ & $\sim$ & 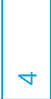 & $\nabla$ & $\sim$ & $N$ & 0 & $\sim$ & - & $\sim$ & $\sim$ & 0 & $N$ \\
\hline 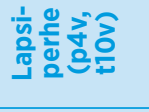 & $\nabla$ & - & $\sim$ & $\begin{array}{l}\mathcal{L} \\
\text { ڤn }\end{array}$ & & $\sim$ & $\sim$ & $m$ & $m$ & $\sim$ & - & - & $\sim$ & 0 & - & - & $\sim$ & - \\
\hline 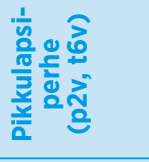 & $\theta$ & - & $\sim$ & in & & - & $\sim$ & $\sim$ & $\sim$ & $\sim$ & 0 & $\sim$ & $\sim$ & 0 & - & - & - & - \\
\hline 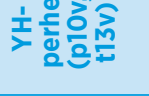 & $m$ & $\tilde{n}^{n}$ & - & $\vec{\sigma}_{0}^{+}$ & & - & $\sim$ & $m$ & $m$ & - & $N$ & 0 & $\sim$ & - & $\sim$ & 0 & - & $N$ \\
\hline 立突定 & - & 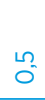 & - & $\stackrel{\sim}{\sim}$ & & - & - & - & 0 & - & 0 & - & $\sim$ & 0 & - & $\circ$ & $\circ$ & 0 \\
\hline 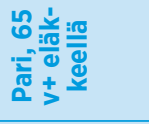 & 6 & - & $\sim$ & 0 & & - & - & $\sim$ & $\sim$ & $\sim$ & 0 & 0 & $\sim$ & 0 & - & - & 0 & - \\
\hline 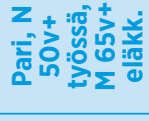 & $\nabla$ & - & $\sim$ & 0 & & - & - & $\sim$ & $\sim$ & $\sim$ & 0 & 0 & $\sim$ & 0 & - & - & 0 & - \\
\hline 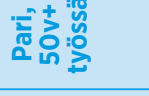 & $\sim$ & - & $\sim$ & 0 & & - & - & $\sim$ & $\sim$ & $\sim$ & 0 & 0 & $\sim$ & 0 & - & - & 0 & - \\
\hline 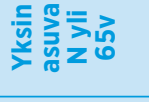 & $m$ & $\tilde{L}^{2}$ & - & 0 & & - & - & - & - & - & 0 & 0 & $v$ & 0 & - & $\circ$ & 0 & - \\
\hline 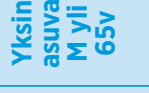 & $m$ & ? & - & 0 & & - & - & - & - & - & 0 & 0 & 0 & 0 & 0 & - & $\circ$ & 0 \\
\hline 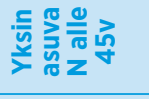 & - & $\begin{array}{l}\tilde{L}_{0} \\
0^{\circ}\end{array}$ & - & 0 & & - & - & - & - & - & 0 & 0 & $\sim$ & 0 & - & 0 & 0 & - \\
\hline 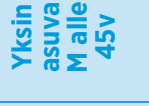 & - & $0^{-1}$ & - & 0 & & - & - & - & - & - & 0 & 0 & 0 & 0 & 0 & - & 0 & 0 \\
\hline 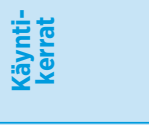 & 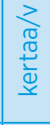 & 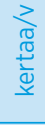 & 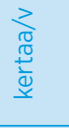 & $\frac{\mathcal{2}}{\varrho}$ & 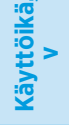 & $\stackrel{\curvearrowleft}{\llcorner}$ & 0 & $\nabla$ & 6 & $\wedge$ & $\sim$ & $\sim$ & $\nabla$ & $m$ & 6 & 0 & $M$ & 으 \\
\hline 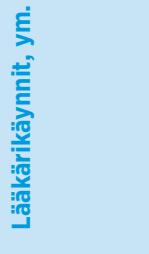 & 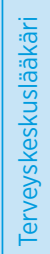 & 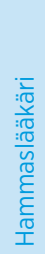 & 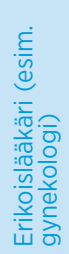 & 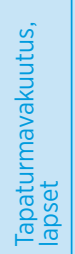 & 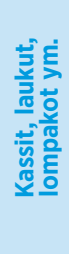 & 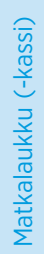 & 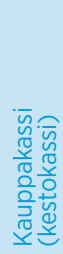 & 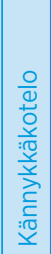 & 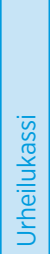 & 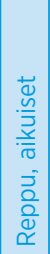 & 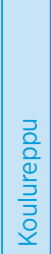 & 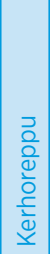 & 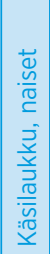 & 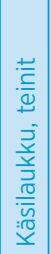 & 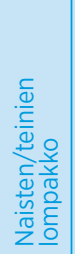 & 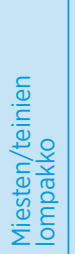 & 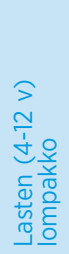 & 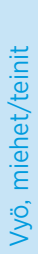 \\
\hline
\end{tabular}




\begin{tabular}{|c|c|c|c|c|c|c|c|c|c|c|c|}
\hline 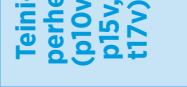 & $\nabla$ & - & $\nabla$ & - & in & เn & in & 0 & & 8 & \\
\hline 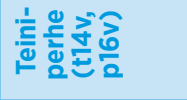 & $\nabla$ & 0 & $\nabla$ & 0 & $\nabla$ & $\forall$ & $\nabla$ & 0 & & 足 & 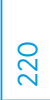 \\
\hline 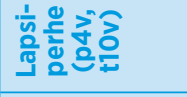 & $\sim$ & $\sim$ & $\sim$ & $\sim$ & $\nabla$ & $M$ & $M$ & - & & 员 & \\
\hline 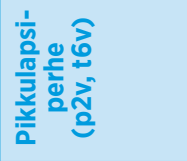 & $\sim$ & $\sim$ & $\sim$ & $\sim$ & $m$ & $\sim$ & $\sim$ & - & & 官 & ○ \\
\hline 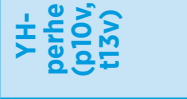 & $v$ & - & $\sim$ & - & $m$ & $M$ & $M$ & 0 & & 官 & ○ \\
\hline 立突疋 & - & - & - & - & - & - & - & - & & ¿ & $\stackrel{\circ}{\circ}$ \\
\hline 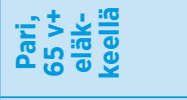 & $\sim$ & 0 & $\sim$ & 0 & $\sim$ & $\sim$ & $N$ & 0 & & 율 & 음 \\
\hline 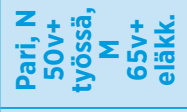 & $\sim$ & 0 & $\sim$ & 0 & $\sim$ & $\sim$ & $\sim$ & 0 & & 윰 & 음 \\
\hline 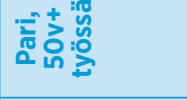 & $\sim$ & 0 & $\sim$ & 0 & $\sim$ & $\sim$ & $\sim$ & 0 & & 윰 & 용 \\
\hline 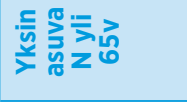 & - & 0 & - & 0 & - & - & - & 0 & & 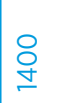 & $\begin{array}{l}\bigcirc \\
\varrho\end{array}$ \\
\hline 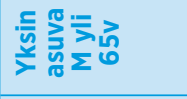 & - & 0 & - & 0 & - & - & - & 0 & & $\begin{array}{l}\text { O } \\
\text { 엄 } \\
\end{array}$ & $\stackrel{0}{6}$ \\
\hline 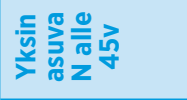 & - & 0 & - & 0 & - & - & - & 0 & & 号 & 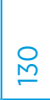 \\
\hline 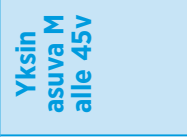 & - & 0 & - & 0 & - & - & - & 0 & & \begin{tabular}{|l} 
\\
O \\
\end{tabular} & ํㅗㅁ \\
\hline 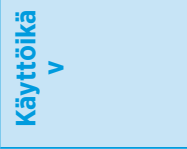 & 으 & $M$ & 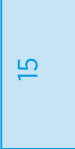 & $m$ & $\stackrel{2}{\llcorner}$ & in & 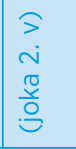 & $m$ & & $\sum_{i}^{2}$ & $>$ \\
\hline 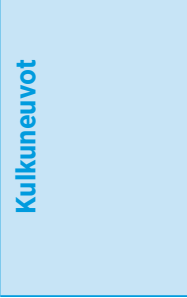 & 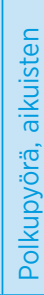 & 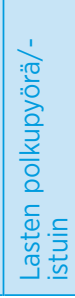 & 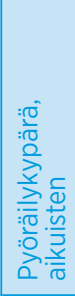 & 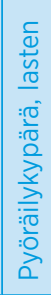 & 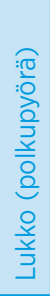 & 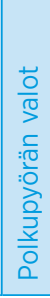 & 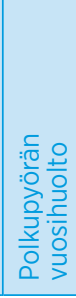 & 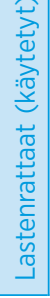 & 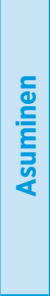 & 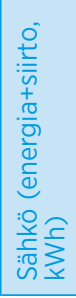 & 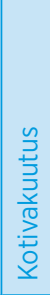 \\
\hline
\end{tabular}


Liite 1 Hyödykeluettelo $\quad 14 / 14$

\begin{tabular}{|c|c|c|c|c|c|c|c|c|c|c|c|}
\hline 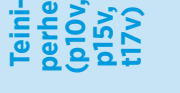 & & $\stackrel{\sim}{\sim}$ & $\stackrel{\sim n}{\sim}$ & - & & & 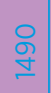 & 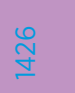 & $\stackrel{\infty}{\stackrel{\infty}{=}}$ & กู & 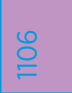 \\
\hline 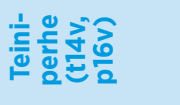 & & $\sim$ & $\sim$ & - & & \begin{tabular}{|l} 
章 \\
年
\end{tabular} & 옴 & $\stackrel{\mathscr{Z}}{\underset{I}{\Psi}}$ & $\stackrel{\infty}{=}$ & กู & $\stackrel{\mathscr{\ell}}{\stackrel{0}{=}}$ \\
\hline 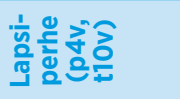 & & $\stackrel{\mathscr{n}}{=}$ & $\stackrel{\sim}{\sim}$ & - & & & $\begin{array}{l}\text { \& } \\
\text { I }\end{array}$ & $\stackrel{\stackrel{\mathscr{V}}{\Xi}}{ }$ & $\begin{array}{l}\stackrel{\infty}{=} \\
=\end{array}$ & กู & 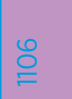 \\
\hline 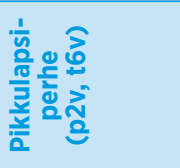 & & - & - & - & & 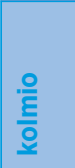 & $\stackrel{\bullet}{\risingdotseq}$ & $\stackrel{\infty}{\cong}$ & Ñ & 옥 & $\begin{array}{l}\infty \\
\infty \\
\infty\end{array}$ \\
\hline 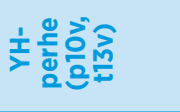 & & $\sim$ & $\sim$ & 0 & & & $\stackrel{\varrho}{\risingdotseq}$ & $\stackrel{\stackrel{\infty}{\Perp}}{=}$ & ले & $\stackrel{\circ}{\perp}$ & $\begin{array}{l}0 \\
\infty \\
\infty\end{array}$ \\
\hline 立突令 & & - & - & 0 & & 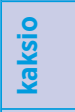 & สี & $\begin{array}{l}\mathscr{2} \\
\infty \\
\end{array}$ & $\underset{N}{\mathbb{N}}$ & $\stackrel{2}{8}$ & $\begin{array}{l}7 \\
\infty \\
0 \\
\end{array}$ \\
\hline 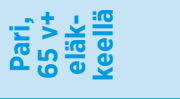 & & $\stackrel{\bullet}{\sim}$ & $\circ$ & 0 & & & $\stackrel{\varrho}{\risingdotseq}$ & $\stackrel{\stackrel{\infty}{\Perp}}{\cong}$ & Nે & 옥 & $\begin{array}{l}0 \\
\infty \\
\infty\end{array}$ \\
\hline 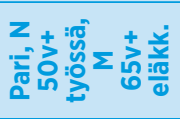 & & $\stackrel{\infty}{=}$ & - & 0 & & $\frac{\circ}{\underline{\underline{E}}}$ & 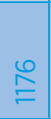 & $\stackrel{\infty}{\cong}$ & స̃ & 옥 & $\begin{array}{l}\infty \\
\infty \\
\infty\end{array}$ \\
\hline 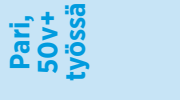 & & $\sim$ & $\sim$ & 0 & & & 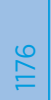 & 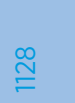 & Ň & 옥 & $\begin{array}{l}\infty \\
\infty \\
\infty\end{array}$ \\
\hline 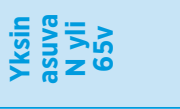 & & $\begin{array}{l}\infty \\
0^{-}\end{array}$ & 0 & 0 & & 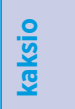 & สี & ஜ̊ & $\underset{\mathbb{N}}{\mathbb{N}}$ & 옹 & $\begin{array}{l}\forall \\
0 \\
0\end{array}$ \\
\hline 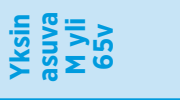 & & $\begin{array}{l}\infty \\
0^{-}\end{array}$ & 0 & 0 & & & సี & $\begin{array}{l}\circ \\
\infty \\
\infty\end{array}$ & $\underset{\mathbb{N}}{\stackrel{ \pm}{2}}$ & 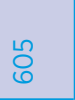 & $\begin{array}{l}7 \\
0 \\
0\end{array}$ \\
\hline 든 & & - & - & 0 & & $\frac{: 0}{5}$ & $\stackrel{\infty}{\stackrel{\infty}{\wedge}}$ & $\stackrel{M}{N}$ & ๙ั & 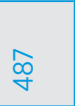 & हิ \\
\hline 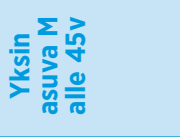 & & - & - & 0 & & & $\stackrel{\infty}{\stackrel{\infty}{\sim}}$ & $\stackrel{M}{N}$ & 今ั & 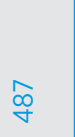 & in \\
\hline & & 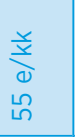 & $\begin{array}{l}\stackrel{y}{\dot{x}} \\
\stackrel{1}{0} \\
\stackrel{0}{0}\end{array}$ & 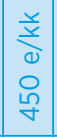 & & & $\stackrel{r}{\stackrel{y}{\partial}}$ & $\stackrel{\stackrel{r}{\alpha}}{\alpha}$ & $\frac{\vec{r}}{\partial}$ & $\stackrel{\text { r }}{\partial}$ & $\stackrel{\stackrel{r}{x}}{\alpha}$ \\
\hline 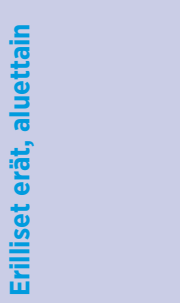 & 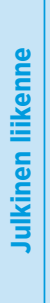 & 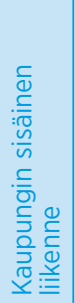 & 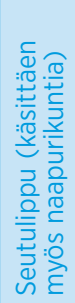 & 号 & 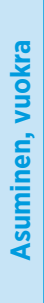 & 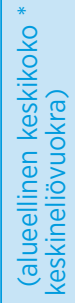 & 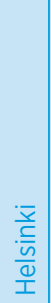 & 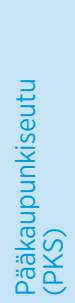 & 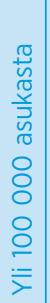 & 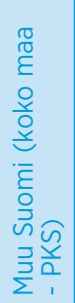 & 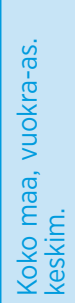 \\
\hline
\end{tabular}




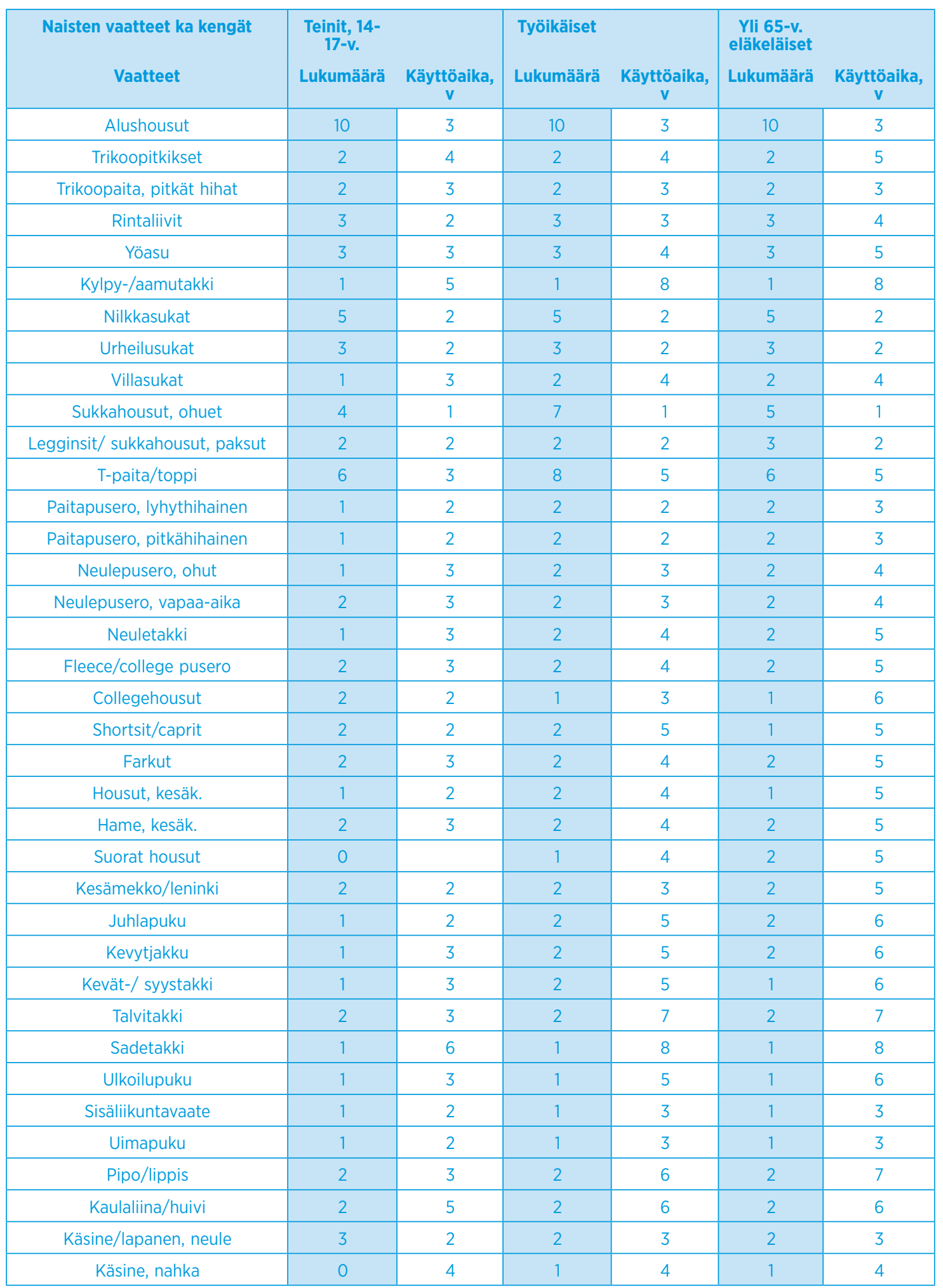


Liite 2 Vaateluettelot

$2 / 6$

\begin{tabular}{|c|c|c|c|c|c|c|}
\hline $\begin{array}{c}\text { Naisten vaatteet ja kengät } \\
\text { Kengät }\end{array}$ & $\begin{array}{c}\text { Teinit, 14- } \\
\text { 17-v. } \\
\text { Lukumäärä }\end{array}$ & Käyttöaika & $\begin{array}{l}\text { Työikäiset } \\
\text { Lukumäärä }\end{array}$ & Käyttöaika & $\begin{array}{l}\text { Yli 65-v. } \\
\text { eläkeläiset } \\
\text { Lukumäärä }\end{array}$ & Käyttöaika \\
\hline Kotikengat/tossut & 0 & & 0 & & 1 & 10 \\
\hline Sandaalit & 1 & 2 & 1 & 3 & 1 & 3 \\
\hline Kengät kesäkäyttöön & 2 & 2 & 2 & 2 & 2 & 3 \\
\hline Kävelykengät & 0 & & 1 & 2 & 1 & 3 \\
\hline Avokkaat/juhlakengät & 1 & 3 & 2 & 5 & 2 & 5 \\
\hline Talvisaappaat /-kengät & 1 & 3 & 2 & 5 & 2 & 6 \\
\hline Kumisaappaat & 1 & 6 & 1 & 8 & 1 & 8 \\
\hline Lenkkitossut & 1 & 1 & 1 & 3 & 1 & 3 \\
\hline Kenkien pohjalliset & 2 & 2 & 2 & 2 & 2 & 2 \\
\hline Irrotettavat liukuesteet & 0 & & 1 & 7 & 1 & 7 \\
\hline
\end{tabular}




\begin{tabular}{|c|c|c|c|c|c|c|}
\hline Miesten vaatteet ja kengät & $\begin{array}{c}\text { Teinit, 14- } \\
\text { 17-v. }\end{array}$ & & Työikäiset & & $\begin{array}{l}\text { Yli } 65-v . \\
\text { eläkeläiset }\end{array}$ & \\
\hline Vaatteet & Lukumäärä & $\underset{\text { Väyttöaika, }}{\text { V }}$ & Lukumäärä & $\begin{array}{c}\text { Käyttöaika, } \\
\text { v }\end{array}$ & Lukumäärä & $\begin{array}{c}\text { Käyttöaika, } \\
\text { V }\end{array}$ \\
\hline Alushousut & 8 & 2 & 8 & 3 & 8 & 3 \\
\hline Alushousut, pitkät & 2 & 2 & 2 & 4 & 2 & 5 \\
\hline Pyjama/yöasu & 2 & 3 & 2 & 4 & 2 & 5 \\
\hline Kylpy-/aamutakki & 0 & & 1 & 7 & 1 & 7 \\
\hline Sukat, ohuet & 6 & 2 & 10 & 2 & 10 & 2 \\
\hline Urheilusukat & 4 & 2 & 3 & 2 & 3 & 2 \\
\hline Sukat, paksut & 3 & 2 & 3 & 3 & 3 & 3 \\
\hline Villasukat & 1 & 4 & 1 & 4 & 1 & 4 \\
\hline T-paita/pikeepaita & 6 & 2 & 6 & 3 & 6 & 4 \\
\hline Miesten paita, Iyhythihainen & 2 & 2 & 2 & 3 & 2 & 4 \\
\hline Miesten paita, pitkähihainen & 2 & 2 & 4 & 2 & 4 & 3 \\
\hline Neulepusero, ohut & 0 & & 2 & 3 & 2 & 3 \\
\hline Neulepusero, vapaa-aika & 2 & 2 & 2 & 3 & 2 & 4 \\
\hline Neuletakki/huppari & 3 & 2 & 2 & 4 & 2 & 4 \\
\hline Villapaita & 1 & 2 & 1 & 5 & 1 & 6 \\
\hline Fleece/college pusero & 3 & 2 & 2 & 3 & 2 & 3 \\
\hline Shortsit & 2 & 3 & 2 & 4 & 2 & 4 \\
\hline Farkut & 2 & 2 & 2 & 3 & 2 & 4 \\
\hline Collegehousut & 2 & 2 & 2 & 3 & 1 & 3 \\
\hline Suorat housut & 0 & 2 & 1 & 4 & 1 & 4 \\
\hline Puku & 1 & 3 & 1 & 7 & 1 & 7 \\
\hline Pusakka & 2 & 3 & 2 & 5 & 2 & 5 \\
\hline Talvitakki & 1 & 2 & 2 & 5 & 2 & 7 \\
\hline Ulkoiluhousut & 1 & 2 & 1 & 5 & 1 & 5 \\
\hline Sadetakki & 1 & 6 & 1 & 8 & 1 & 8 \\
\hline Ulkoilupuku & 1 & 2 & 1 & 5 & 1 & 6 \\
\hline Sisäliikuntavaate & 1 & 2 & 1 & 3 & 1 & 3 \\
\hline Uimapuku/ -housut & 1 & 2 & 1 & 4 & 1 & 4 \\
\hline Solmio & 1 & 6 & 1 & 7 & 1 & 7 \\
\hline Lippalakki & 2 & 2 & 2 & 4 & 2 & 4 \\
\hline Рipo & 2 & 3 & 2 & 5 & 2 & 5 \\
\hline Kaulaliina/huivi & 1 & 4 & 1 & 6 & 1 & 6 \\
\hline Käsine, neule & 3 & 3 & 1 & 3 & 1 & 3 \\
\hline Käsine, nahka & 0 & & 2 & 4 & 2 & 4 \\
\hline
\end{tabular}




\begin{tabular}{|c|c|c|c|c|c|c|}
\hline $\begin{array}{c}\text { Miesten vaatteet ja kengät } \\
\text { Kengät }\end{array}$ & $\begin{array}{c}\text { Teinit, 14- } \\
\text { 17-v. } \\
\text { Lukumäärä }\end{array}$ & Käyttöaika & $\begin{array}{l}\text { Työikäiset } \\
\text { Lukumäärä }\end{array}$ & Käyttöaika & $\begin{array}{l}\text { Yli 65-v. } \\
\text { eläkeläiset } \\
\text { Lukumäärä }\end{array}$ & Käyttöaika \\
\hline Kotikengat/tossut & 0 & 10 & 0 & 10 & 1 & 10 \\
\hline Sandaalit & 1 & 2 & 1 & 3 & 1 & 3 \\
\hline Kengät kesäkäyttöön & 1 & 2 & 1 & 3 & 1 & 3 \\
\hline Kävelykengät & 0 & & 1 & 3 & 1 & 4 \\
\hline Juhlakengät & 1 & 2 & 1 & 10 & 1 & 10 \\
\hline Talvikengät & 1 & 2 & 1 & 3 & 1 & 4 \\
\hline Kumisaappaat & 1 & 4 & 1 & 8 & 1 & 8 \\
\hline Lenkkitossut & 1 & 1 & 1 & 3 & 1 & 3 \\
\hline Kenkien pohjalliset & 2 & 2 & 3 & 2 & 3 & 2 \\
\hline Irrotettavat liukuesteet & 0 & & 1 & 7 & 1 & 7 \\
\hline
\end{tabular}




\begin{tabular}{|c|c|c|c|c|c|c|c|c|c|}
\hline $\begin{array}{l}\text { Lasten vaatteet ja } \\
\text { kengät }\end{array}$ & $\begin{array}{l}\text { Luku- } \\
\text { määrä }\end{array}$ & & $\begin{array}{l}\text { Käyttö- } \\
\text { aika }\end{array}$ & $\begin{array}{l}\text { Luku- } \\
\text { määrä }\end{array}$ & & $\begin{array}{l}\text { Käyttö- } \\
\text { aika }\end{array}$ & $\begin{array}{l}\text { Luku- } \\
\text { määrä }\end{array}$ & & $\begin{array}{c}\text { Käyttö- } \\
\text { taika }\end{array}$ \\
\hline Vaatteet & $\begin{array}{l}\text { pojat, } \\
2-5 \mathrm{~V}\end{array}$ & $\begin{array}{l}\text { tytöt, } \\
2-5 \text { v }\end{array}$ & v. & $\begin{array}{l}\text { pojat, } \\
6-9 \mathrm{v}\end{array}$ & $\begin{array}{l}\text { tytöt, } \\
6-9 \mathrm{v}\end{array}$ & v. & $\begin{array}{l}\text { pojat, } \\
10-13 \mathrm{v}\end{array}$ & $\begin{array}{l}\text { tytöt, } \\
10-13 \mathrm{v}\end{array}$ & v. \\
\hline Alushousut & 8 & 8 & 2 & 7 & 8 & 2 & 7 & 8 & 2 \\
\hline Alushousut, pitkät & 2 & 0 & 2 & 1 & 0 & 2 & 1 & & 2 \\
\hline Yöasu/pyjama & 3 & 3 & 2 & 3 & 3 & 2 & 3 & 3 & 2 \\
\hline Kylpy-/aamutakki & 1 & 1 & 2 & 1 & 1 & 3 & 1 & 1 & 3 \\
\hline Nilkkasukat, ohuet & 6 & 5 & 1 & 6 & 5 & 1 & 6 & 5 & 1 \\
\hline Sukat, paksut & 2 & 2 & 1 & 2 & 2 & 2 & 3 & 2 & 2 \\
\hline Jarrusukat & 3 & 3 & 1 & 1 & 1 & 1 & 0 & 0 & \\
\hline Villasukat & 1 & 1 & 2 & 1 & 1 & 2 & 1 & 1 & 2 \\
\hline Sukkahousut, ohuet & 0 & 1 & 1 & 0 & 1 & 1 & 0 & 1 & 1 \\
\hline Paksut sukkahousut & 0 & 2 & 1 & 0 & 2 & 1 & 0 & 1 & 1 \\
\hline Legginsit, trikoohousut & 0 & 2 & 1 & 0 & 4 & 1 & 0 & 4 & 1 \\
\hline T-paita/pikeepaita & 6 & 6 & 1 & 6 & 6 & 1 & 6 & 6 & 1 \\
\hline Trikoopaita, pitkät hihat & 6 & 6 & 1 & 6 & 6 & 1 & 6 & 6 & 1 \\
\hline Fleece/college paita & 2 & 2 & 1 & 2 & 2 & 1 & 2 & 2 & 1 \\
\hline Neuletakki/huppari & 2 & 2 & 1 & 2 & 2 & 1 & 3 & 3 & 2 \\
\hline Fleece/college housut & 4 & 3 & 1 & 5 & 3 & 1 & 4 & 3 & 1 \\
\hline Farkut & 2 & 1 & 1 & 2 & 2 & 1 & 2 & 2 & 1 \\
\hline Housut, kesäk. & 1 & 1 & 1 & 1 & 1 & 1 & 1 & 1 & 1 \\
\hline Shortsit & 1 & 1 & 1 & 2 & 2 & 2 & 2 & 2 & 2 \\
\hline (Kesä)mekko & 0 & 2 & 1 & 0 & 2 & 2 & 0 & 2 & 2 \\
\hline Hame & 0 & 0 & 0 & 0 & 1 & 2 & 0 & 1 & 2 \\
\hline Juhla-asu /juhlamekko & 1 & 1 & 1 & 1 & 1 & 1 & 1 & 1 & 1 \\
\hline Toppatakki & 1 & 1 & 1 & 1 & 1 & 1 & 1 & 1 & 2 \\
\hline Toppahousut & 2 & 2 & 1 & 2 & 2 & 2 & 1 & 1 & 2 \\
\hline Sadetakki & 1 & 1 & 2 & 1 & 1 & 2 & 1 & 1 & 2 \\
\hline $\begin{array}{l}\text { Kurahousut/sadetta } \\
\text { pitävät }\end{array}$ & 1 & 1 & 2 & 0 & 0 & & 0 & 0 & \\
\hline Ulkoilutakki (välikausi) & 1 & 1 & 1 & 1 & 1 & 1 & 1 & 1 & 2 \\
\hline Ulkohousut (välikausi) & 2 & 2 & 1 & 1 & 1 & 1 & 1 & 1 & 1 \\
\hline Uimapuku/ -housut & 1 & 1 & 1 & 1 & 1 & 1 & 1 & 1 & 1 \\
\hline Pipo & 2 & 2 & 2 & 2 & 2 & 2 & 2 & 2 & 2 \\
\hline Lippalakki/kesähattu & 2 & 2 & 1 & 1 & 1 & 1 & 2 & 2 & 2 \\
\hline Kypärämyssy & 1 & 1 & 3 & 1 & 1 & 2 & 0 & 0 & \\
\hline $\begin{array}{c}\text { Kaulaliina/kauluri/huivi/ } \\
\text { tuubi }\end{array}$ & 2 & 2 & 3 & 2 & 3 & 3 & 2 & 2 & 3 \\
\hline Sormikkaat, neule & 1 & 1 & 1 & 1 & 2 & 1 & 2 & 2 & 2 \\
\hline Lapaset & 2 & 2 & 1 & 2 & 2 & 1 & 1 & 1 & 2 \\
\hline Rukkaset, vuorilliset & 1 & 1 & 1 & 1 & 1 & 1 & 1 & 1 & 1 \\
\hline $\begin{array}{c}\text { Rukkaset, vedenpitävät/ } \\
\text { kura- }\end{array}$ & 1 & 1 & 1 & 1 & 1 & 1 & 1 & 1 & 2 \\
\hline
\end{tabular}




\begin{tabular}{|c|c|c|c|c|c|c|c|c|c|}
\hline Kengät & $\begin{array}{c}\text { Lkm/ } \\
\text { pojat, } \\
\mathbf{2 - 5} \mathbf{~ v}\end{array}$ & $\begin{array}{c}\text { Lkm/ } \\
\text { tytöt, } \\
\mathbf{2 - 5} \mathbf{~ v}\end{array}$ & $\begin{array}{c}\text { Käyttö- } \\
\text { aika }\end{array}$ & $\begin{array}{c}\text { Lkm/ } \\
\text { pojat, } \\
\mathbf{6 - 9} \mathbf{~ v}\end{array}$ & $\begin{array}{c}\text { Lkm/ } \\
\text { tytöt, } \\
\mathbf{6 - 9} \mathbf{~ v}\end{array}$ & $\begin{array}{c}\text { Käyttö- } \\
\text { aika }\end{array}$ & $\begin{array}{c}\text { Lkm/ } \\
\text { pojat, } \\
\mathbf{1 0}-\mathbf{1 3} \mathbf{~ v}\end{array}$ & $\begin{array}{c}\text { Lkm/ } \\
\text { tytöt, } \\
\mathbf{1 0}-13 \mathbf{v}\end{array}$ & $\begin{array}{c}\text { Käyttö- } \\
\text { aika }\end{array}$ \\
\hline Sisätossut & 1 & 1 & 1 & 1 & 1 & 1 & 0 & 0 & 1 \\
\hline Sandaalit/kesäkengät & 1 & 1 & 1 & 2 & 2 & 1 & 2 & 2 & 1 \\
\hline Tennarit /loaferit & 1 & 1 & 1 & 1 & 1 & 1 & 1 & 1 & 1 \\
\hline Lenkkitossut & 1 & 1 & 1 & 1 & 1 & 1 & 1 & 1 & 1 \\
\hline Juhlakengät & 0 & 1 & 1 & 1 & 1 & 1,5 & 1 & 1 & 1,5 \\
\hline Talvisaappaat /-kengät & 1 & 1 & 1 & 1 & 1 & 1 & 1 & 1 & 1 \\
\hline Kumisaappaat & 1 & 1 & 2 & 1 & 1 & 2 & 1 & 1 & 2 \\
\hline Kenkien pohjalliset & 1 & 1 & 1 & 1 & 1 & 1 & 1 & 1 & 1 \\
\hline
\end{tabular}


Tummennus: ruokailu kodin ulkopuolella (henkilöstöravintola, kahvila tms.)

Ruokajuoma: rasvaton maito, iäkkäillä kevyt maito

Leipä: täysjyväruisleipä tai kauraleipä, levite 60\%.

\begin{tabular}{|c|c|c|c|c|c|c|c|}
\hline & Yksin asuva all & 45, yhden ja k & ahden vanhemma & n lapsiperheet & & & \\
\hline 1. & MA & $\mathrm{TI}$ & KE & TO & PE & LA & SU \\
\hline$\frac{\frac{5}{0}}{\frac{. \frac{\pi}{E}}{E}}$ & $\begin{array}{c}\text { Kaurapuuro, } \\
\text { marjasose, } \\
\text { maito, } \\
\text { leipä, levite, } \\
\text { leikkele, } \\
\text { kasvis, } \\
\text { kahvi/tee }\end{array}$ & $\begin{array}{c}\text { Kaurapuuro } \\
\text { ym. }\end{array}$ & Kaurapuuro ym. & $\begin{array}{c}\text { Jogurtti, leipä, } \\
\text { levite, leikkele, } \\
\text { hedelmä, kahvi/ } \\
\text { tee }\end{array}$ & Jogurtti ym. & & \\
\hline 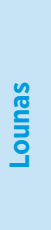 & $\begin{array}{l}\text { Kinkkupasta, } \\
\text { porkkana- } \\
\text { ananasraaste, }\end{array}$ & $\begin{array}{l}\text { Broilerkasvis- } \\
\text { risotto, } \\
\text { porkkana- } \\
\text { ananasraaste, }\end{array}$ & $\begin{array}{l}\text { Kalakeitto, } \\
\text { salaattipöytä, } \\
\text { kuumennettu, } \\
\text { kasvis }\end{array}$ & $\begin{array}{c}\text { Liha- tai } \\
\text { kasvispyörykät, } \\
\text { perunasose, } \\
\text { salaattipöytä, } \\
\text { kuumennettu } \\
\text { kasvis, } \\
\text { puolukkasurvos }\end{array}$ & $\begin{array}{c}\text { Chili con/sin } \\
\text { carne, riisi, } \\
\text { salaattipöytä } \\
\text { kuumennettu } \\
\text { kasvis, }\end{array}$ & $\begin{array}{c}\text { Runsas } \\
\text { aamiainen } \\
\text { (puuro, } \\
\text { leipä, } \\
\text { kananmuna, } \\
\text { leikkele, } \\
\text { kasvis, } \\
\text { kahvi/tee, }\end{array}$ & $\begin{array}{l}\text { Runsas } \\
\text { aamiainen }\end{array}$ \\
\hline $\begin{array}{l}\frac{\pi}{\pi} \\
\frac{0}{2} \\
\frac{10}{3}\end{array}$ & $\begin{array}{l}\text { Rahka, } \\
\text { hedelmä, } \\
\text { kahvi/tee }\end{array}$ & $\begin{array}{l}\text { Jogurtti, } \\
\text { hedelmä, } \\
\text { kahvi/tee }\end{array}$ & $\begin{array}{l}\text { Rahka, hedelmä, } \\
\text { kahvi/tee }\end{array}$ & $\begin{array}{c}\text { Jogurtti, } \\
\text { pähkinät, kahvi/ } \\
\text { tee }\end{array}$ & $\begin{array}{l}\text { Rahka, } \\
\text { hedelmä, } \\
\text { kahvi/tee }\end{array}$ & $\begin{array}{c}\text { Kahvi/ } \\
\text { tee/mehu, } \\
\text { pullaviipale, } \\
\text { hedelmä }\end{array}$ & $\begin{array}{c}\text { Kahvi/ } \\
\text { tee/mehu, } \\
\text { pullaviipale, } \\
\text { hedelmä }\end{array}$ \\
\hline 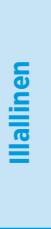 & $\begin{array}{l}\text { Broilerkasvis- } \\
\text { risotto viher- } \\
\text { sekasalaatti }\end{array}$ & $\begin{array}{l}\text { Juuressose- } \\
\text { keitto karjalan- } \\
\text { piirakka, } \\
\text { raejuusto, } \\
\text { tomaatti }\end{array}$ & $\begin{array}{l}\text { Pastavuoka, } \\
\text { viherseka- } \\
\text { salaatti }\end{array}$ & $\begin{array}{l}\text { Juuressosekeitto, } \\
\text { karjalanpiirakka, } \\
\text { raejuusto, } \\
\text { tomaatti }\end{array}$ & $\begin{array}{l}\text { Broilerkasvis- } \\
\text { nuudeliwok, } \\
\text { vihersalaatti }\end{array}$ & $\begin{array}{l}\text { Pizza- } \\
\text { aterian } \\
\text { hintainen } \\
\text { ruokailu } \\
\text { kodin } \\
\text { ulkopuolella }\end{array}$ & $\begin{array}{l}\text { Paistettu } \\
\text { lohifile, } \\
\text { peruna, } \\
\text { kermaviili- } \\
\text { kastike, } \\
\text { viherseka- } \\
\text { salaatti, } \\
\text { marjat }\end{array}$ \\
\hline $\begin{array}{l}\frac{\pi}{\pi} \\
\stackrel{\circ}{\frac{0}{0}} \\
\stackrel{=}{=}\end{array}$ & $\begin{array}{l}\text { Leipä, levite, } \\
\text { leikkele, } \\
\text { kasvis, } \\
\text { marjakeitto }\end{array}$ & $\begin{array}{l}\text { Rahka, } \\
\text { marjakeitto }\end{array}$ & $\begin{array}{l}\text { Jogurtti, leipä, } \\
\text { levite, leikkele, } \\
\text { kasvis }\end{array}$ & $\begin{array}{l}\text { Leipä, leikkele, } \\
\text { kasvis, tee tai } \\
\text { maito }\end{array}$ & $\begin{array}{c}\text { Jogurtti, } \\
\text { leipä, levite, } \\
\text { leikkele, } \\
\text { kasvis }\end{array}$ & $\begin{array}{c}\text { Jogurtti, } \\
\text { hedelmä/ } \\
\text { marjat }\end{array}$ & $\begin{array}{l}\text { Rahka, } \\
\text { pähkinät, } \\
\text { kasvis }\end{array}$ \\
\hline 2. & MA & TI & KE & TO & PE & LA & SU \\
\hline 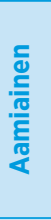 & Jogurtti ym. & $\begin{array}{c}4 \text { viljanpuuro, } \\
\text { maito, } \\
\text { marjasose, } \\
\text { leipä, levite, } \\
\text { leikkele, } \\
\text { kasvis, kahvi/ } \\
\text { tee }\end{array}$ & $\begin{array}{c}4 \text { viljan puuro } \\
\text { ym. }\end{array}$ & Kaurapuuro ym. & Jogurtti ym. & & \\
\hline 桭 & $\begin{array}{l}\text { Lohikiusaus, } \\
\text { aurinko- } \\
\text { salaatti }\end{array}$ & $\begin{array}{l}\text { Bolognese, } \\
\text { spagetti, } \\
\text { aurinko- } \\
\text { salaatti }\end{array}$ & $\begin{array}{c}\text { Kasvis- } \\
\text { sienikääryleet, } \\
\text { peruna, } \\
\text { puolukka- } \\
\text { survos, } \\
\text { salaattipöytä }\end{array}$ & $\begin{array}{c}\text { Broiler- } \\
\text { stroganoff } \\
\text { peruna, } \\
\text { kuumennettu } \\
\text { kasvis, } \\
\text { salaattipöytä }\end{array}$ & $\begin{array}{c}\text { Uunikala, } \\
\text { peruna, } \\
\text { paaahdetut } \\
\text { kasvikset, } \\
\text { salaattipöytä }\end{array}$ & $\begin{array}{c}\text { Runsas } \\
\text { aamiainen }\end{array}$ & $\begin{array}{c}\text { Runsas } \\
\text { aamiainen }\end{array}$ \\
\hline $\begin{array}{l}\frac{\pi}{\pi} \\
\stackrel{\circ}{\frac{0}{2}} \\
\frac{10}{>}\end{array}$ & $\begin{array}{l}\text { Jogurtti, } \\
\text { pähkinät, } \\
\text { kahvi/tee }\end{array}$ & $\begin{array}{l}\text { Jogurtti, } \\
\text { hedelmä, } \\
\text { kahvi/tee }\end{array}$ & $\begin{array}{l}\text { Rahka, } \\
\text { hedelmä, } \\
\text { kahvi/tee }\end{array}$ & $\begin{array}{c}\text { Rahka, } \\
\text { pähkinät, kahvi/ } \\
\text { tee }\end{array}$ & $\begin{array}{l}\text { Rahka, } \\
\text { hedelmä, } \\
\text { kahvi/tee }\end{array}$ & $\begin{array}{c}\text { Kahvi/ } \\
\text { tee/mehu, } \\
\text { pullaviipale, } \\
\text { hedelmä }\end{array}$ & $\begin{array}{c}\text { Kahvi/tee/ } \\
\text { mehu } \\
\text { pullaviipale, } \\
\text { hedelmä }\end{array}$ \\
\hline 突 & $\begin{array}{l}\text { Bolognese, } \\
\text { spagetti, } \\
\text { tomaatti, } \\
\text { kurkku }\end{array}$ & $\begin{array}{l}\text { Pinaattikeitto, } \\
\text { kananmuna, } \\
\text { leipä, } \\
\text { tomaatti }\end{array}$ & $\begin{array}{l}\text { Kalakeitto, } \\
\text { leipä, juusto, } \\
\text { tomaatti }\end{array}$ & $\begin{array}{c}\text { Peruna- } \\
\text { kasvispihvit, } \\
\text { kermaviili- } \\
\text { kastike, } \\
\text { raejuusto- } \\
\text { porkkana-raaste }\end{array}$ & $\begin{array}{l}\text { Broiler- } \\
\text { fetasalaatti }\end{array}$ & Tortilla & $\begin{array}{c}\text { Juurespata, } \\
\text { perunat, } \\
\text { viherseka- } \\
\text { salaatti, } \\
\text { leipä, maito, } \\
\text { marjarahka }\end{array}$ \\
\hline $\begin{array}{l}\frac{\pi}{\pi} \\
\stackrel{\circ}{\frac{\pi}{0}} \\
=\end{array}$ & $\begin{array}{c}\text { Täysjyväleipä, } \\
\text { levite, } \\
\text { leikkele, } \\
\text { kasvis, maito }\end{array}$ & $\begin{array}{c}\text { Rahka, } \\
\text { marjakeitto }\end{array}$ & $\begin{array}{c}\text { Jogurtti, leipä, } \\
\text { levite, leikkele, } \\
\text { kasvis }\end{array}$ & $\begin{array}{c}\text { Täysjyväleipä, } \\
\text { levite, leikkele, } \\
\text { kasvis, maito }\end{array}$ & $\begin{array}{l}\text { Täysjyväleipä, } \\
\text { levite, } \\
\text { leikkele, } \\
\text { kasvis, maito }\end{array}$ & $\begin{array}{l}\text { Jogurtti, } \\
\text { levite, leipä, } \\
\text { leikkele, } \\
\text { kasvis }\end{array}$ & $\begin{array}{l}\text { Rahka, } \\
\text { pähkinät, } \\
\text { kasvis }\end{array}$ \\
\hline
\end{tabular}




\begin{tabular}{|c|c|c|c|c|c|c|c|}
\hline \multicolumn{8}{|c|}{ Yksin asuva yli 65 , pariskunta50+ ja $65+$ ja pariskunta $65+$} \\
\hline 1. & MA & TI & KE & TO & PE & LA & SU \\
\hline$\frac{\frac{c}{d}}{\frac{.0}{\frac{0}{c}}}$ & $\begin{array}{l}\text { Kaurapuuro, } \\
\text { marjasose, } \\
\text { maito, leipä, } \\
\text { leikkele, } \\
\text { kasvis, kahvi/ } \\
\text { tee }\end{array}$ & $\begin{array}{c}\text { Kaurapuuro } \\
\text { ym. }\end{array}$ & $\begin{array}{l}4 \text { viljanpuuro, } \\
\text { marjasose, } \\
\text { maito, leipä, } \\
\text { leikkele, kasvis, } \\
\text { kahvi/tee }\end{array}$ & $\begin{array}{c}\text { Kaurapuuro } \\
\text { ym. }\end{array}$ & $\begin{array}{c}\text { Kaurapuuro } \\
\text { ym. }\end{array}$ & $\begin{array}{c}4 \text { viljanpuuro } \\
\text { ym. }\end{array}$ & \\
\hline $\begin{array}{l}\text { c } \\
\text { c } \\
\text { 오 }\end{array}$ & $\begin{array}{l}\text { Makaroni- } \\
\text { laatikko, } \\
\text { ketsuppi, } \\
\text { porkkana- } \\
\text { raaste }\end{array}$ & $\begin{array}{l}\text { Makaroni- } \\
\text { laatikko, } \\
\text { ketsuppi, } \\
\text { aurinko- } \\
\text { salaatti }\end{array}$ & $\begin{array}{l}\text { Lounas ja } \\
\text { välipala kodin } \\
\text { ulkopuolella }\end{array}$ & $\begin{array}{c}\text { Kaalilaatikko, } \\
\text { puolukka- } \\
\text { survos, } \\
\text { etikka- } \\
\text { punajuuri }\end{array}$ & $\begin{array}{l}\text { Kalakeitto, } \\
\text { tomaatti, } \\
\text { leipä, levite }\end{array}$ & $\begin{array}{l}\text { Kalakeitto, } \\
\text { tomaatti, } \\
\text { leipä, levite }\end{array}$ & $\begin{array}{c}\text { Runsas } \\
\text { aamiainen } \\
\text { (puuro, leipä, } \\
\text { kananmuna, } \\
\text { leikkele, } \\
\text { kasvis, kahvi/ } \\
\text { tee, }\end{array}$ \\
\hline$\frac{\frac{0}{10}}{\frac{0}{10}}$ & $\begin{array}{l}\text { Jogurtti, } \\
\text { hedelmä, } \\
\text { kahvi/tee }\end{array}$ & $\begin{array}{c}\text { Rahka, kahvi/ } \\
\text { tee }\end{array}$ & & $\begin{array}{l}\text { Jogurtti, } \\
\text { hedelmä } \\
\text { kahvi/tee }\end{array}$ & $\begin{array}{l}\text { Rahka, } \\
\text { hedelmä, } \\
\text { kahvi/tee }\end{array}$ & $\begin{array}{l}\text { Kahvi/tee, } \\
\text { pullaviipale, } \\
\text { hedelmä }\end{array}$ & $\begin{array}{c}\text { Kahvi/tee, } \\
\text { pullaviipale, } \\
\text { hedelmä }\end{array}$ \\
\hline $\begin{array}{l}\text { c } \\
\text { 竞 } \\
\text { 三 }\end{array}$ & $\begin{array}{c}\text { Juuressose- } \\
\text { keitto } \\
\text { karjalan- } \\
\text { piirakka, } \\
\text { tomaatti }\end{array}$ & $\begin{array}{l}\text { Pinaatti- } \\
\text { ohukaiset, } \\
\text { puolukka- } \\
\text { survos, } \\
\text { porkkana- } \\
\text { ananasraaste }\end{array}$ & $\begin{array}{c}\text { Juuressose- } \\
\text { keitto, kurkku, } \\
\text { juusto, leipä, } \\
\text { levite }\end{array}$ & $\begin{array}{c}\text { Broilerkastike, } \\
\text { riisi, } \\
\text { porkkana- } \\
\text { raaste }\end{array}$ & $\begin{array}{l}\text { Kaalilaatikko, } \\
\text { puolukkahillo, } \\
\text { aurinko- } \\
\text { salaatti }\end{array}$ & $\begin{array}{l}\text { Boilerinkoipi, } \\
\text { riisi, } \\
\text { vihersalaatti }\end{array}$ & $\begin{array}{l}\text { Paistettu } \\
\text { lohifile, } \\
\text { peruna, } \\
\text { kerma- } \\
\text { viilikastike, } \\
\text { aurinko } \\
\text {-salaatti, } \\
\text { puolukka- } \\
\text { kiisseli }\end{array}$ \\
\hline $\begin{array}{l}\frac{\pi}{\pi} \\
\frac{0}{0} \\
\stackrel{ }{=}\end{array}$ & $\begin{array}{l}\text { Leipä, levite, } \\
\text { leikkele, } \\
\text { kasvis, } \\
\text { marjakeitto }\end{array}$ & $\begin{array}{l}\text { Rahka, } \\
\text { marjakeitto }\end{array}$ & $\begin{array}{c}\text { Jogurtti, leipä, } \\
\text { levite, leikkele, } \\
\text { kasvis }\end{array}$ & $\begin{array}{l}\text { Leipä, } \\
\text { leikkele, } \\
\text { kasvis, tee tai } \\
\text { maito }\end{array}$ & $\begin{array}{l}\text { Jogurtti } \\
\text { hedelmä }\end{array}$ & $\begin{array}{c}\text { Jogurtti, leipä, } \\
\text { levite, leikkele, } \\
\text { kasvis }\end{array}$ & $\begin{array}{l}\text { Rahka, } \\
\text { pähkinät, } \\
\text { kasvis }\end{array}$ \\
\hline 2. & MA & TI & KE & TO & PE & LA & SU \\
\hline 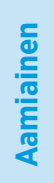 & $\begin{array}{c}\text { Kaurapuuro } \\
\text { ym. }\end{array}$ & $\begin{array}{c}\text { Kaurapuuro } \\
\text { ym. }\end{array}$ & $\begin{array}{c}\text { Kaurapuuro } \\
\text { ym. }\end{array}$ & $\begin{array}{c}4 \text { viljanpuuro } \\
\text { ym. }\end{array}$ & $\begin{array}{c}4 \text { viljanpuuro } \\
\text { ym. }\end{array}$ & $\begin{array}{l}4 \text { viljanpuuro } \\
\text { ym. }\end{array}$ & \\
\hline 气̊ & $\begin{array}{c}\text { Lohikiusaus, } \\
\text { porkkana- } \\
\text { rae- } \\
\text { juustosalaatti }\end{array}$ & $\begin{array}{c}\text { Nakkikastike, } \\
\text { perunasose, } \\
\text { kuumennetut } \\
\text { kasvikset, } \\
\text { kurkku }\end{array}$ & $\begin{array}{l}\text { Perunakasvis- } \\
\text { pihvit, } \\
\text { kermaviili- } \\
\text { kastike, etikka- } \\
\text { punajuuri, } \\
\text { kurkku }\end{array}$ & $\begin{array}{l}\text { Herne- } \\
\text { sosekeitto, } \\
\text { leipä, levite, } \\
\text { tomaatti }\end{array}$ & $\begin{array}{l}\text { Paistetut } \\
\text { muikut/ } \\
\text { silakat, } \\
\text { perunasose, } \\
\text { porkkana- } \\
\text { raaste }\end{array}$ & $\begin{array}{l}\text { Pinaatti- } \\
\text { ohukaiset, } \\
\text { puolukka- } \\
\text { survos, }\end{array}$ & $\begin{array}{l}\text { Runsas } \\
\text { aamiainen }\end{array}$ \\
\hline 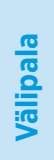 & $\begin{array}{l}\text { Rahka, } \\
\text { hedelmä, } \\
\text { kahvi/tee }\end{array}$ & $\begin{array}{l}\text { Rahka, } \\
\text { hedelmä, } \\
\text { kahvi/tee }\end{array}$ & $\begin{array}{l}\text { Rahka, } \\
\text { hedelmä, } \\
\text { kahvi/tee }\end{array}$ & $\begin{array}{l}\text { Jogurtti, } \\
\text { hedelmä } \\
\text { kahvi/tee }\end{array}$ & $\begin{array}{l}\text { Jogurtti, } \\
\text { hedelmä } \\
\text { kahvi/tee }\end{array}$ & $\begin{array}{l}\text { Kahvi/tee, } \\
\text { pullaviipale, } \\
\text { hedelmä }\end{array}$ & $\begin{array}{c}\text { Kahvi/tee, } \\
\text { pullaviipale, } \\
\text { hedelmä }\end{array}$ \\
\hline 突 & $\begin{array}{c}\text { Kasvisbroiler- } \\
\text { wok } \\
\text { raejuusto- } \\
\text { porkkana- } \\
\text { raaste }\end{array}$ & $\begin{array}{l}\text { Lohikiusaus, } \\
\text { viherseka- } \\
\text { salaaatti }\end{array}$ & $\begin{array}{c}\text { Maksalaatikko, } \\
\text { puolukka- } \\
\text { survos, } \\
\text { tomaatti }\end{array}$ & $\begin{array}{l}\text { Kasvis- } \\
\text { munakas, } \\
\text { mauste- } \\
\text { kurkku, } \\
\text { viherseka- } \\
\text { salaatti }\end{array}$ & $\begin{array}{l}\text { Hernesose- } \\
\text { keitto, leipä, } \\
\text { levite, kurkku }\end{array}$ & $\begin{array}{c}\text { Broilerkiusaus, } \\
\text { maustekurkku, } \\
\text { viherseka- } \\
\text { salaatti }\end{array}$ & $\begin{array}{l}\text { Juurespata, } \\
\text { peruna, } \\
\text { viherseka- } \\
\text { salaatti, } \\
\text { puolukka- } \\
\text { kiisseli }\end{array}$ \\
\hline $\begin{array}{l}\frac{\pi}{\pi} \\
\frac{0}{0} \\
\stackrel{ }{=}\end{array}$ & $\begin{array}{l}\text { Täysjyväleipä, } \\
\text { levit, leikkele, } \\
\text { kasvis, maito }\end{array}$ & $\begin{array}{l}\text { Jogurtti, } \\
\text { hedelmä }\end{array}$ & $\begin{array}{l}\text { Jogurtti, leipä, } \\
\text { levite, leikkele, } \\
\text { kasvis }\end{array}$ & $\begin{array}{c}\text { Täysjyväleipä, } \\
\text { leikkele, } \\
\text { levite, kasvis, } \\
\text { marjakeitto }\end{array}$ & $\begin{array}{c}\text { Täysjyväleipä, } \\
\text { leikkele, } \\
\text { levite, kasvis, } \\
\text { marjakeitto }\end{array}$ & $\begin{array}{l}\text { Jogurtti, leipä, } \\
\text { levite, leikkele, } \\
\text { kasvis }\end{array}$ & $\begin{array}{l}\text { Rahka, } \\
\text { pähkinät, } \\
\text { kasvis }\end{array}$ \\
\hline
\end{tabular}




\begin{tabular}{|c|c|c|c|c|c|c|c|}
\hline & Pariskunta 50 & & & & & & \\
\hline 1. & MA & TI & KE & TO & PE & LA & SU \\
\hline$\frac{\frac{c}{0}}{\frac{.}{0}}$ & $\begin{array}{c}\text { Kaurapuuro, } \\
\text { marjasose, } \\
\text { maito, leipä, } \\
\text { levite, leikkele, } \\
\text { kasvis, kahvi/ } \\
\text { tee }\end{array}$ & $\begin{array}{c}\text { Kaurapuuro } \\
\text { ym. }\end{array}$ & $\begin{array}{l}\text { Kaurapuuro } \\
\text { yms }\end{array}$ & $\begin{array}{l}4 \text { viljanpuuro, } \\
\text { marjasose, } \\
\text { maito, leipä, } \\
\text { levite, leikkele, } \\
\text { kasvis, kahvi/ } \\
\text { tee }\end{array}$ & $\begin{array}{l}\text { Jogurtti, } \\
\text { leipä, levite, } \\
\text { leikkele, } \\
\text { hedelmä, } \\
\text { kahvi/tee }\end{array}$ & & \\
\hline 兄 & $\begin{array}{l}\text { Makaroni- } \\
\text { laatikko, } \\
\text { porkkana- } \\
\text { ananasraaste }\end{array}$ & $\begin{array}{l}\text { Broilerkasvis- } \\
\text { risotto, } \\
\text { porkkana- } \\
\text { ananasraaste }\end{array}$ & $\begin{array}{l}\text { Kalakeitto, } \\
\text { leipä, } \\
\text { salaattipöytä, } \\
\text { kuumennettu } \\
\text { kasvis }\end{array}$ & $\begin{array}{c}\text { Liha- tai } \\
\text { kasvispyörykät, } \\
\text { perunasose, } \\
\text { salaattipöytä, } \\
\text { kuumennettu } \\
\text { kasvis, } \\
\text { puolukkasurvos }\end{array}$ & $\begin{array}{l}\text { Chili con/sin } \\
\text { carne, riisi, } \\
\text { kuumennettu } \\
\text { kasvis, } \\
\text { salaatipöytä }\end{array}$ & $\begin{array}{c}\text { Runsas } \\
\text { aamiainen } \\
\text { (puuro, } \\
\text { leipä, } \\
\text { kananmuna, } \\
\text { kasvis, } \\
\text { leikkele } \\
\text { kahvi/tee,) }\end{array}$ & $\begin{array}{l}\text { Runsas } \\
\text { aamiainen }\end{array}$ \\
\hline $\begin{array}{l}\frac{\pi}{\pi} \\
\frac{0}{10} \\
>\end{array}$ & $\begin{array}{l}\text { Rahka, } \\
\text { hedelmä, } \\
\text { kahvi/tee }\end{array}$ & $\begin{array}{l}\text { Jogurtti, } \\
\text { hedelmä, } \\
\text { kahvi/tee }\end{array}$ & $\begin{array}{l}\text { Rahka, } \\
\text { hedelmä, } \\
\text { kahvi/tee }\end{array}$ & $\begin{array}{l}\text { Jogurtti, } \\
\text { pähkinät, } \\
\text { kahvi/tee }\end{array}$ & $\begin{array}{l}\text { Rahka, } \\
\text { hedelmä, } \\
\text { kahvi/tee }\end{array}$ & $\begin{array}{l}\text { Kahvi/tee, } \\
\text { hedelmä, } \\
\text { pullaviipale }\end{array}$ & $\begin{array}{l}\text { Kahvi/tee, } \\
\text { pullaviipale, } \\
\text { suklaapala }\end{array}$ \\
\hline 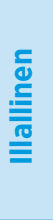 & $\begin{array}{l}\text { Broilerkasvis- } \\
\text { risotto, } \\
\text { viherseka- } \\
\text { salaatti }\end{array}$ & $\begin{array}{l}\text { Juuressose- } \\
\text { keitto, } \\
\text { karjalan- } \\
\text { piirakka, } \\
\text { raejuusto, } \\
\text { tomaatti }\end{array}$ & $\begin{array}{l}\text { Makaroni- } \\
\text { laatikko, } \\
\text { viherseka- } \\
\text { salaatti }\end{array}$ & $\begin{array}{l}\text { Juuressose- } \\
\text { keitto, karjalan- } \\
\text { piirakka, } \\
\text { raejuusto, } \\
\text { tomaatti }\end{array}$ & $\begin{array}{l}\text { Broilerkasvis- } \\
\text { nuudeliwok, } \\
\text { viherseka- } \\
\text { salaatti }\end{array}$ & $\begin{array}{l}\text { Pizza- } \\
\text { aterian } \\
\text { hintainen } \\
\text { ruokailu } \\
\text { kodin } \\
\text { ulkopuolella }\end{array}$ & $\begin{array}{c}\text { Paistettu } \\
\text { lohifile, } \\
\text { kermaviili- } \\
\text { kastike, } \\
\text { peruna, } \\
\text { viherseka- } \\
\text { salaatti, marjat }\end{array}$ \\
\hline $\begin{array}{l}\frac{\pi}{\pi} \\
\frac{0}{0} \\
\stackrel{0}{=}\end{array}$ & $\begin{array}{c}\text { Täysjyväleipä, } \\
\text { levite, leikkele, } \\
\text { kasvis, } \\
\text { marjakeitto }\end{array}$ & $\begin{array}{l}\text { Jogurtti, } \\
\text { leipä, levite, } \\
\text { leikkele, } \\
\text { kasvis }\end{array}$ & $\begin{array}{l}\text { Rahka, } \\
\text { marjakeitto }\end{array}$ & $\begin{array}{c}\text { Täysjyväleipä, } \\
\text { leikkele, kasvis, } \\
\text { maito }\end{array}$ & $\begin{array}{l}\text { Jogurtti, } \\
\text { hedelmä/ } \\
\text { marjat }\end{array}$ & $\begin{array}{l}\text { Jogurtti, } \\
\text { leipä, levite, } \\
\text { leikkele, } \\
\text { kasvis }\end{array}$ & $\begin{array}{l}\text { Rahka, } \\
\text { pähkinät, } \\
\text { kasvis }\end{array}$ \\
\hline 2. & MA & TI & KE & TO & PE & LA & SU \\
\hline$\frac{\frac{c}{0}}{\frac{. \overline{0}}{E}}$ & $\begin{array}{c}\text { Kaurapuuro, } \\
\text { maito, } \\
\text { marjasose, } \\
\text { leipälevite, } \\
\text { leikkele, kasvis, } \\
\text { kahvi/tee }\end{array}$ & $\begin{array}{l}4 \text { viljanpuuro, } \\
\text { marjasose, } \\
\text { maito, } \\
\text { leipä, levite, } \\
\text { leikkele, } \\
\text { kasvis, kahvi/ } \\
\text { tee }\end{array}$ & $\begin{array}{c}4 \text { viljan } \\
\text { puuro ym. }\end{array}$ & Kaurapuuro ym. & $\begin{array}{c}\text { Jogurtti, } \\
\text { leipä, levite, } \\
\text { leikkele, } \\
\text { hedelmä, } \\
\text { kahvi/tee }\end{array}$ & & \\
\hline 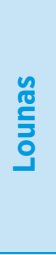 & $\begin{array}{l}\text { Lohikiusaus, } \\
\text { aurinkosalaatti }\end{array}$ & $\begin{array}{l}\text { Bolognese, } \\
\text { spagetti, } \\
\text { aurinko- } \\
\text { salaatti }\end{array}$ & $\begin{array}{l}\text { Kasvissieni- } \\
\text { kääryleet, } \\
\text { peruna, } \\
\text { puolukka- } \\
\text { survos, } \\
\text { salaattipöytä }\end{array}$ & $\begin{array}{c}\text { Broiler- } \\
\text { stroganoff, } \\
\text { peruna, } \\
\text { kuumennettu } \\
\text { kasvis, } \\
\text { salaattipöytä }\end{array}$ & $\begin{array}{c}\text { Uunikala, } \\
\text { peruna, } \\
\text { paaahdetut } \\
\text { kasvikset, } \\
\text { salaattipöytä }\end{array}$ & $\begin{array}{c}\text { Runsas } \\
\text { aamiainen } \\
\text { (puuro, } \\
\text { leipä, } \\
\text { kananmuna, } \\
\text { kasvis, } \\
\text { leikkele } \\
\text { kahvi/tee,) }\end{array}$ & $\begin{array}{c}\text { Runsas } \\
\text { aamiainen }\end{array}$ \\
\hline 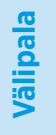 & $\begin{array}{l}\text { Jogurtti, } \\
\text { pähkinät, } \\
\text { kahvi/tee }\end{array}$ & $\begin{array}{l}\text { Jogurtti, } \\
\text { hedelmä, } \\
\text { kahvi/tee }\end{array}$ & $\begin{array}{l}\text { Rahka, } \\
\text { hedelmä, } \\
\text { kahvi/tee }\end{array}$ & $\begin{array}{l}\text { Rahka, } \\
\text { pähkinät, } \\
\text { kahvi/tee }\end{array}$ & $\begin{array}{l}\text { Rahka, } \\
\text { hedelmä, } \\
\text { kahvi/tee }\end{array}$ & $\begin{array}{l}\text { Kahvi/tee, } \\
\text { hedelmä, } \\
\text { pullaviipale }\end{array}$ & $\begin{array}{l}\text { Kahvi/tee, } \\
\text { hedelmä, } \\
\text { pullaviipale }\end{array}$ \\
\hline 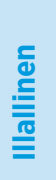 & $\begin{array}{l}\text { Bolognese, } \\
\text { spagetti, } \\
\text { viherseka- } \\
\text { salaatti, }\end{array}$ & $\begin{array}{l}\text { Kalakeitto, } \\
\text { leipä, juusto, } \\
\text { tomaatti }\end{array}$ & $\begin{array}{l}\text { Pinaatti- } \\
\text { keitto, leipä, } \\
\text { kananmuna, } \\
\text { tomaatti }\end{array}$ & $\begin{array}{l}\text { Perunakasvis- } \\
\text { pihvit, kerma- } \\
\text { viilikastike, } \\
\text { raejuusto- } \\
\text { porkkanaraaste }\end{array}$ & $\begin{array}{l}\text { Broiler- } \\
\text { fetasalaatti, } \\
\text { leipä }\end{array}$ & Tortilla & $\begin{array}{c}\text { Juurespata, } \\
\text { peruna, } \\
\text { vihersalaatti, } \\
\text { leipä, maito, } \\
\text { marjarahka }\end{array}$ \\
\hline $\begin{array}{l}\frac{\pi}{\pi} \\
\stackrel{\circ}{\frac{0}{0}} \\
\stackrel{\underbrace{}}{=}\end{array}$ & $\begin{array}{l}\text { Täysjyväleipä, } \\
\text { levit, leikkele, } \\
\text { kasvis, maito }\end{array}$ & $\begin{array}{c}\text { Jogurtti, } \\
\text { leipä, levite, } \\
\text { leikkele, } \\
\text { kasvis }\end{array}$ & $\begin{array}{l}\text { Jogurtti, } \\
\text { leipä, levite, } \\
\text { leikkele, } \\
\text { kasvis }\end{array}$ & $\begin{array}{c}\text { Jogurtti, } \\
\text { hedelmä/marjat }\end{array}$ & $\begin{array}{l}\text { Täysjyväleipä, } \\
\text { leikkele, } \\
\text { levite, kasvis, } \\
\text { marjakeitto }\end{array}$ & $\begin{array}{l}\text { Jogurtti, } \\
\text { levite, leipä, } \\
\text { leikkele, } \\
\text { kasvis }\end{array}$ & $\begin{array}{l}\text { Rahka, } \\
\text { pähkinät, } \\
\text { kasvis }\end{array}$ \\
\hline
\end{tabular}

